\title{
POLITÉCNICA
}

UNIVERSIDAD POLITÉCNICA DE MADRID

ESCUELA TÉCNICA SUPERIOR

DE INGENIEROS AGRÓNOMOS

\section{ESTUDIO DE LA ESTABILIDAD GENÉTICA \\ ASOCIADA A LOS PROCESOS DE \\ CRIOCONSERVACIÓN DE ÁPICES DE MENTA}

- Tesis doctoral -

MARÍA CAROLINA KREMER MORALES

Ingeniera Agrónoma

2016 



\title{
ESTUDIO DE LA ESTABILIDAD GENÉTICA ASOCIADA A LOS PROCESOS DE CRIOCONSERVACIÓN DE ÁPICES DE MENTA
}

\author{
- Tesis doctoral - \\ MARÍA CAROLINA KREMER MORALES \\ Ingeniera Agrónoma
}

Directores:

María Elena González Benito (Doctora Ingeniera Agrónoma)

María Carmen Martín Fernández (Doctora Ingeniera Agrónoma) 



\section{POLITÉCNICA}

Tribunal de defensa de tesis nombrado por el Mgfco. Y Excmo. Sr. Rector de la Universidad Politécnica de Madrid, el día _ de enero de 2016.

Presidente: Dr. D.

Vocal: $\quad$ Dra. D.

Vocal: Dra. D.

Vocal: $\quad$ Dra. D.

Secretario: $\operatorname{Dr}^{\mathrm{a}}$. D 

Las doctoras María Elena González Benito, Catedrática de Universidad, y María Carmen Martín Fernández, profesora titular, ambas del Departamento de Biotecnología-Biología Vegetal (Universidad Politécnica de Madrid),

CERTIFICAN QUE la presente Tesis Doctoral titulada "ESTUDIO DE LA ESTABILIDAD GENÉTICA ASOCIADA A LOS PROCESOS DE CRIOCONSERVACIÓN DE ÁPICES DE MENTA”, ha sido realizada bajo su dirección por la ingeniera agrónoma Dña. María Carolina Kremer Morales. 



\section{AGRADECIMIENTOS}

Gracias a la Universidad Politécnica de Madrid y al Programa de Doctorado en Biotecnología y Recursos Genéticos de Plantas y Microorganismos Asociados por la beca Ayuda a la realización de Doctorado y al proyecto "CRYODYMINT" (AGL2010-21989C02-02) del Ministerio de Ciencia e Innovación del Gobierno de España.

Gracias a las directoras de esta tesis, la Dra. M. Elena González Benito y la Dra. M. Carmen Martín Fernández, del Dpto. de Biotecnología-Biología Vegetal de la Universidad Politécnica de Madrid (UPM), por su paciencia, por toda su ayuda, por las enseñanzas que me han brindado en el ámbito de la investigación todos estos años. Sin ustedes no habría podido llevar a cabo esta tesis.

Mis agradecimientos al Centro de Investigaciones Biológicas-CSIC, y a la colaboración de la Dra. Pilar Sánchez Testillano, investigadora y responsable del grupo de Biotecnología del Polen de Plantas Cultivadas y la Dra. María Teresa Solís, investigadora perteneciente al mismo grupo, por su ayuda en el laboratorio y revisión del manuscrito.

Gracias a los técnicos que trabajan en los laboratorios de cultivo in vitro y de Biología del departamento de Biotecnología-Biología Vegetal de la UPM: Carlos Ruiz, Consuelo Sansegundo y en especial a Marta Huertas, por su ayuda y su amistad.

Muchas gracias a Iván González, por su ayuda y compañerismo en el laboratorio.

A las personas que fui conociendo y compartiendo trabajo, compañia y amistad durante este proceso, Sara Mira, Aline Schneider, Chaneze Amira, Natacha Cohelo.

A mi esposo Pablo por su apoyo, comprensión, ánimo. A mis hijas Jimena e Isabel, que han nacido y vivido hasta ahora con esta tesis, por su paciencia y darme lo mejor siempre. A mis suegros, Maribel y José Manuel por su ayuda con las peques siempre que lo necesitamos. A mis padres y mi hermano Roland por su preocupación y las energías que siempre me mandaban a través de la distancia. A mis hermanos Werner y Soledad por toda su ayuda y apoyo, sobre todo cuando han estado en España. 



\section{INDICE}

\section{Página}

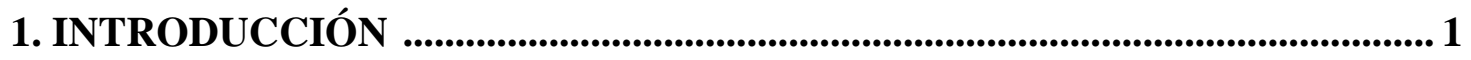

1.1.Conservación de Recursos Fitogenéticos de Especies Propagadas

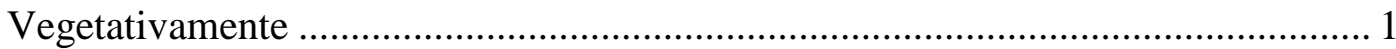

1. 2.Conservación de RRFF de Especies Propagadas Vegetativamente ................... 3

1.2.1. Conservación de Bampo ............................................................................. 3

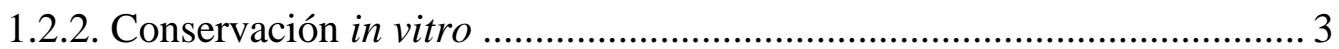

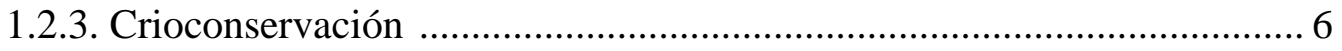

1.3. Estabilidad Genética en el Cultivo in vitro y Crioconservación ................... 12

1.3.1. Marcadores Basados en la hibridación del ADN................................... 14

1.3.2. Marcadores Basados en la PCR .......................................................... 14

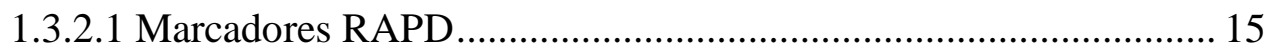

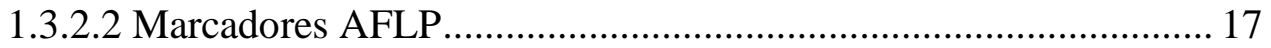

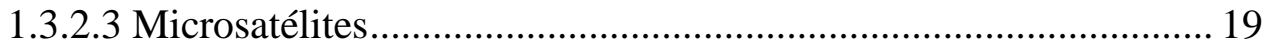

1.3.2.4 Otros Marcadores ......................................................................... 20

1.4. Daño Oxidativo en el Cultivo in vitro y Crioconservación ............................. 21

1.5. Especie Objeto del Estudio Mentha × piperita L. ....................................... 29

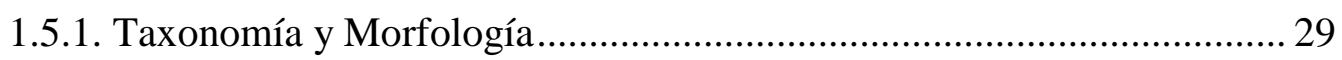

1.5.2. Cultivo, Importancia yUsos ............................................................. 31

1.5.3. Conservación in vitro y Crioconservación de Menta .............................. 32

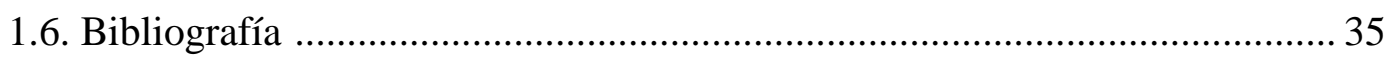

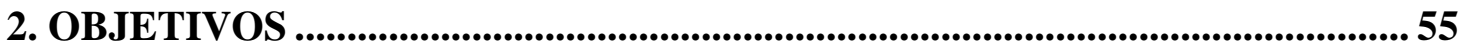




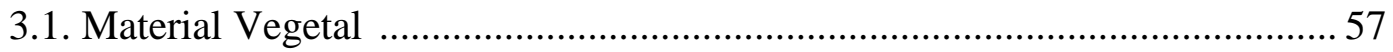

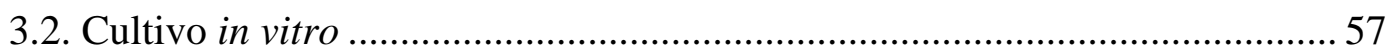

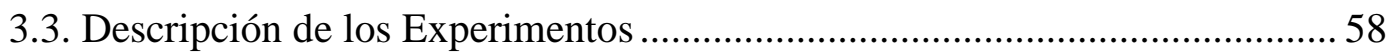

3.3.1. Influencia de la técnica de crioconservación, medio de recuperación y el genotipo en la recuperación y la estabilidad genética de ápices de menta crioconservados

3.3.2. Efecto de sustancias antioxidantes en la recuperación y estabilidad genética después de la crioconservación mediante encapsulación-deshidratación

3.3.3. Efecto de sustancias antioxidantes en la recuperación y estabilidad genética después de cada paso del protocolo de crioconservación mediante encapsulación-deshidratación

3.4. Bibliografía

\section{INFLUENCE OF THE CRYOPRESERVATION TECHNIQUE,} RECOVERY MEDIUM AND GENOTYPE ON RECOVERY AND GENETIC STABILITY OF MINT CRYOPRESERVED SHOOT TIPS

4.1. Regeneration in mint (Mentha $\times$ piperita L.) cryopreserved apices: can the cryopreservation technique, recovery medium composition and genotype affect the final result?

4.1.1. Abstract

4.1.2. Introduction 68

4.1.3. Material and Methods

4.1.3.1 Plant Material and Preconditioning Treatments 69

4.1.3.2 Cryopreservation by Encapsulation-Dehydration 69

4.1.3.3 Cryopreservation by Droplet-Vitrification 70 
4.1.3.4 Recovery ............................................................................. 71

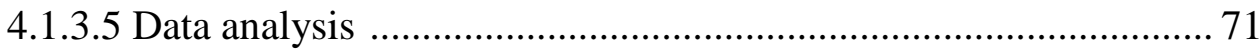

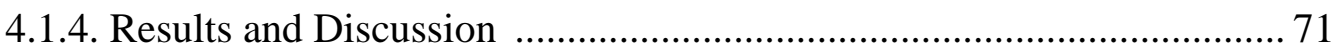

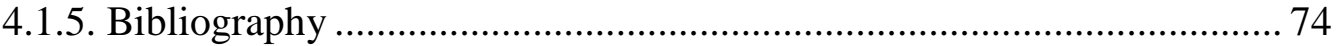

4.2. Influence of the cryopreservation technique, recovery medium and genotype on genetic stability of mint cryopreserved shoot tips ........................... 76

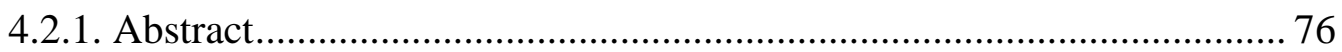

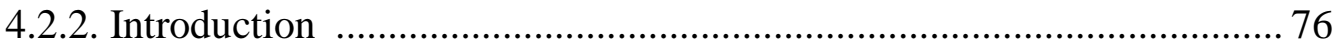

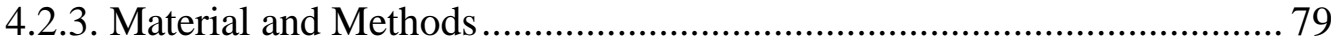

4.2.3.1 Plant Material and Preconditioning Treatments ......................... 79

4.2.3.2 Cryopreservation by Encapsulation-Dehydration......................... 80

4.2.3.3 Cryopreservation by Droplet-Vitrification .................................. 80

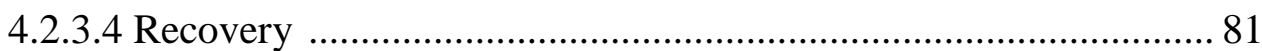

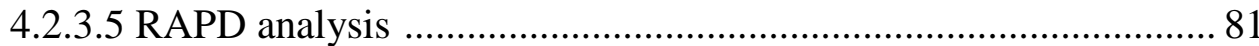

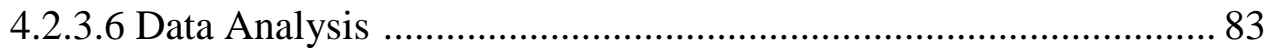

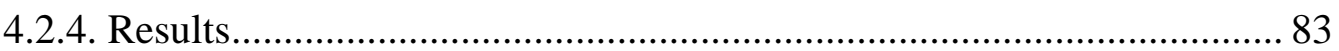

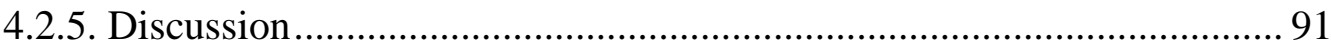

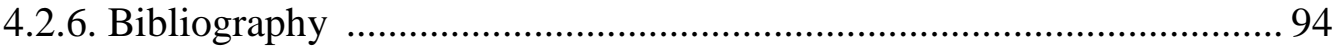

\section{EFFECT OF ANTIOXIDANTS ON THE GENETIC STABILITY OF CRYOPRESERVED MINT SHOOT TIPS BY ENCAPSULATION-}

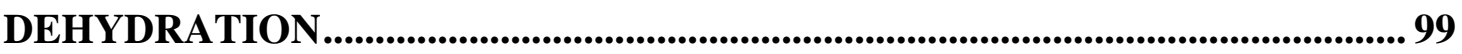

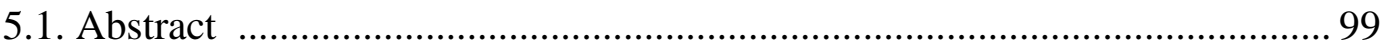

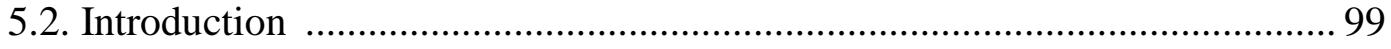


5.3. Materials and Methods

5.3.1. Plant Material and Preconditioning Treatments 102

5.3.2. Cryopreservation 103

5.3.3. Sampling and DNA isolation 103

5.3.4. RAPD analysis 104

5.3.5. AFLP analysis 104

5.3.6. Data Analysis 105

5.4. Results 106

5.5. Discussion 115

5.6. Bibliography

6. ESTUDIO SECUENCIAL DE UN PROTOCOLO DE CRIOCONSERVACIÓN MEDIANTE ENCAPSULACIÓNDESHIDRATACIÓN: EFECTO DE LA UTILIZACIÓN DE ANTIOXIDANTES SOBRE LA ESTABILIDAD GENÉTICA ........................... 121

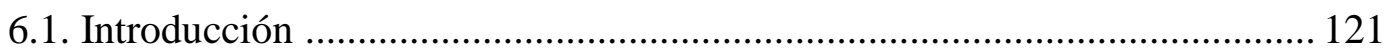

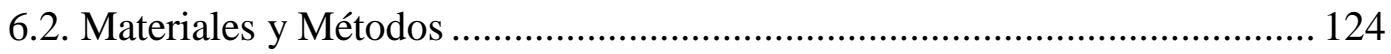

6.2.1. Aclimatación de Segmentos Nodales y Precultivo de Ápices.............. 124

6.2.2. Crioconservación Mediante Encapsulación-Deshidratación ............... 125

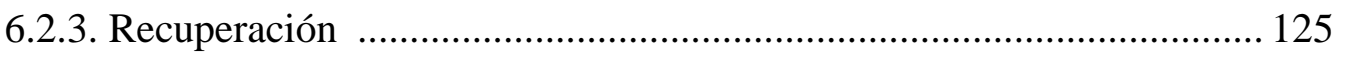

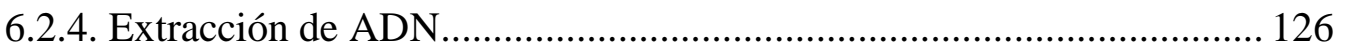

6.2.5. Marcadores Moleculares RAPDs ................................................... 127

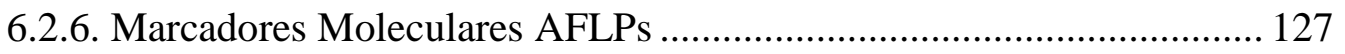

6.2.7. Medición ROS y NO Mediante Fluorocromos...................................... 128

6.2.8. Cuantificación de Malondialdehído.................................................... 130 
6.2.9. Determinación de la Capacidad Antioxidante Mediante el Método ABTS

6.2.10. Análisis de Datos ......................................................................... 132

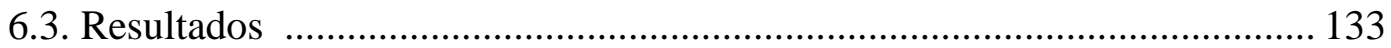

6.3.1. Recuperación de los Ápices.................................................................... 133

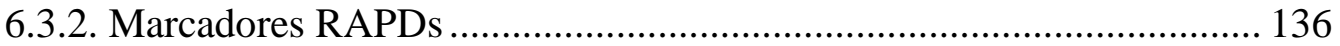

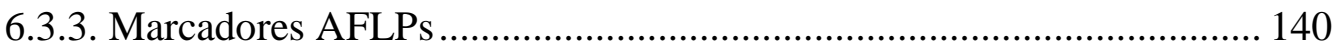

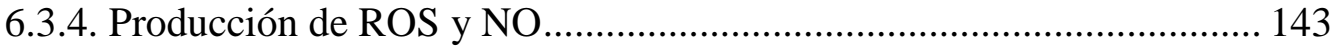

6.3.5. Cuantificación de MDA.................................................................... 148

6.3.6. Determinación de la Capacidad Antioxidante Mediante el Método ABTS

6.4. Discusión 150

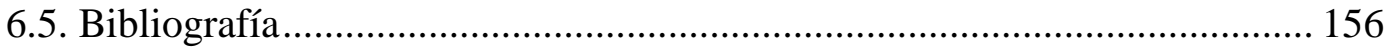

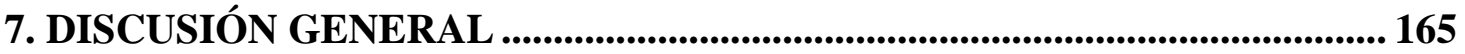

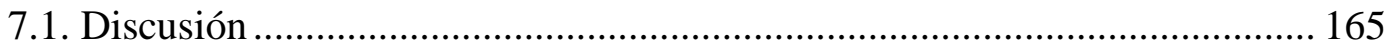

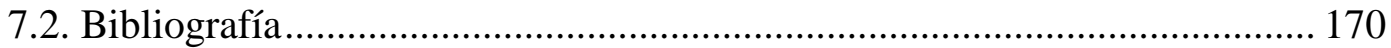

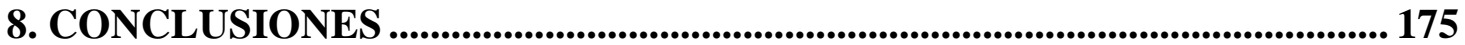

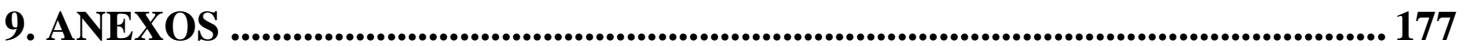

Anexo I. Análisis Estadístico Recuperación de Ápices en Estudio

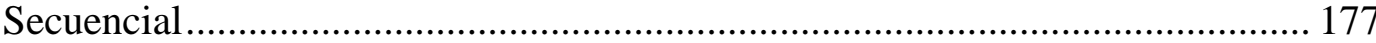

Anexo II. Análisis estadístico del efecto de la utilización de antioxidantes en etapa "P” en la formación de callo en pasos “S”, “D” y “Cr” de la encapsulación-deshidratación 
Anexo III. Análisis estadístico estabilidad genética en marcadores moleculares RAPDs del efecto de la utilización de antioxidantes en etapa “P” en cada paso de la encapsulación-deshidratación

Anexo IV. Análisis estadístico, estabilidad genética en marcadores moleculares AFLPs del efecto de la utilización de antioxidantes en etapa "P” en cada paso de la encapsulación-deshidratación.

Anexo V. Imágenes producción de ROS y $\mathrm{NO}$ en pasos de la encapsulación-deshidratación y efecto de la utilización de antioxidantes en etapas "P" o "S" 


\section{RESUMEN}

La crioconservación se ha descrito como una técnica de conservación ex situ a largo plazo que ha sido aplicada con éxito a numerosas especies, y resulta especialmente importante en aquellas con propagación vegetativa, infértiles o amenazadas, en las que sistemas de conservación ex situ más sencillos, como los bancos de semillas, no son posibles. También presenta ventajas frente a la conservación in vitro, ya que logra disminuir o eliminar problemas como la excesiva manipulación del material, evitando los subcultivos periódicos y disminuyendo así el riesgo de contaminaciones y de aparición de variación somaclonal. Sin embargo, someter al material vegetal a los procedimientos que implica la crioconservación provoca distintos estreses. Entre ellos, el estrés oxidativo puede potencialmente producir daños en membranas, proteínas, carbohidratos y en el ADN.

En este trabajo se han evaluado diversos sistemas de crioconservación en ápices de Mentha $\times$ piperita L., híbrido estéril entre Mentha aquatica L. y Mentha spicata L. Se han utilizado ápices de dos genotipos ('MEN 186'y 'MEN 198') en los cuales se compararon dos técnicas de crioconservación, encapsulación-deshidratación y vitrificación-droplet. El análisis de la supervivencia y capacidad de regeneración del material sometido a los tratamientos de crioconservación, junto con el análisis de la estabilidad genética de dicho material mediante marcadores moleculares (RAPD y AFLP) han permitido comparar los distintos protocolos y tratamientos establecidos. El estudio sobre el tipo de protocolo empleado reveló una mayor variabilidad genética en la técnica de encapsulación-deshidratación, especialmente en el genotipo 'MEN 186', ya que 'MEN 198' resultó ser más estable en todos los análisis. La inestabilidad encontrada en esta técnica no fue exclusiva de aquellos explantos crioconservados, sino que los pasos previos a la inmersión en nitrógeno líquido (NL) también provocaron variaciones en el ADN. Según el tipo de muestra analizada se encontraron diferencias en la estabilidad: muestras provenientes de callos presentaron una mayor inestabilidad que aquellas de hojas (brotes).

Se utilizaron tres medios para la recuperación de los ápices tras la crioconservación con el uso de diferentes combinaciones de reguladores de crecimiento: "Reed" $\left(0,5 \mathrm{mgL}^{-1}\right.$ 6-bencilaminopurina, BAP), "Senula" $\left(0,5 \mathrm{mgL}^{-1}\right.$ 6-dimetilalilamino-purina, 2 -iP + 0,1 $\mathrm{mgL}^{-1}$ ácido $\alpha$-naftalen-acético, ANA) y "Nudos" $\left(0,5 \mathrm{mgL}^{-1} \mathrm{BAP}+0,1 \mathrm{mgL}^{-1} \mathrm{ANA}\right)$. El medio 
"Reed" produjo un aumento en la supervivencia y recuperación de los ápices en ambos genotipos y técnicas, y disminuyó la formación de callo. Sin embargo, no tuvo un efecto significativo en la estabilidad genética. El medio "Senula" provocó una mayor estabilidad genética en el genotipo más inestable, 'MEN 186'.

Para reducir el daño oxidativo producido durante la encapsulación-deshidratación, e incrementar la recuperación de los ápices manteniendo su estabilidad genética, se comparó el efecto de añadir sustancias antioxidantes en el precultivo de los ápices (ácido ascórbico, vitamina E y glutatión). No se obtuvo la respuesta esperada y estos tratamientos no presentaron efectos significativos tanto en la estabilidad como en la recuperación.

Para entender mejor qué sucede durante todo el proceso de encapsulación-deshidratación, se evaluó cada paso del protocolo por separado y su efecto en la estabilidad y la recuperación. Además, se determinó el estado de oxidación en cada etapa mediante la cuantificación de malondialdehído y la detección de la formación de radicales libres (mediante el ensayo del ácido tiobarbitúrico, y sondas fluorescentes específicas, respectivamente). Se determinó que a partir de los primeros pasos se genera estrés oxidativo, el cual aumenta a medida que se avanza por el protocolo hasta la inmersión en nitrógeno líquido. Esto se ve reflejado en la disminución progresiva tanto de la recuperación como de la estabilidad genética. Con el uso de antioxidantes en el precultivo (ácido ascórbico y vitamina E) no se obtuvo un efecto positivo en el mantenimiento de la estabilidad genética, y tan sólo con el uso de vitamina E se observó una recuperación mayor en uno de los pasos estudiados (después de la desecación). Sin embargo, cuando se utilizó ácido ascórbico durante el precultivo o la deshidratación osmótica se consiguió disminuir de forma significativa la formación de MDA y la acumulación del radical superóxido $\left(\mathrm{O}_{2}{ }^{\circ}\right)$ en la mayoría los pasos analizados, aunque esta reducción no parece tener un efecto directo en la estabilidad genética del material recuperado. 


\begin{abstract}
Cryopreservation has been described as an effective technique for the long term of ex situ conservation that has been successfully applied to numerous species, and is of especial relevance for those with vegetative propagation, infertile or endangered, in which simpler systems of ex situ conservation, such as seed banking, are not feasible. It also has advantages over in vitro conservation, as it reduces or eliminates excessive material handling, avoids periodic subcultures and thus limits the risk of contamination and the appearance of somaclonal variation. However, plant material is subjected to different treatments involved in the cryopreservation procedures, which impose several stresses. Among them, oxidative stress can potentially cause damage to membranes, proteins, carbohydrates and DNA.

In this work, two cryopreservation techniques have been evaluated in Mentha $\times$ piperita L. shoot tips, sterile hybrid between Mentha aquatica L. and Mentha spicata L. Two genotypes ('MEN 186' and 'MEN 198') were used to compare two techniques: encapsulation-dehydration and droplet-vitrification. The analysis of survival and recovery capacity of the material after the cryopreservation treatments, and the analysis of the genetic stability by molecular markers (RAPD and AFLP) have enabled the comparison between protocols and treatments. The study of the two cryopreservation procedures revealed a higher genetic variability in the encapsulation-dehydration technique, especially in genotype 'MEN 186', as 'MEN 198' was more stable in all analyses. The instability generated in this technique was not exclusive of cryopreserved explants, pretreatments prior to immersion in NL also caused DNA variations. The type of sampled plant material revealed also differences in the stability: callus samples showed greater instability than shoots.
\end{abstract}

Three different culture media were used for the recovery of shoot tips after cryopreservation, using different combinations of growth regulators: "Reed" $\left(0.5 \mathrm{mgL}^{-1}\right.$ 6-benzylaminopurine, BAP), "Senula" (0.5 mgL-1 6-dimetilalilamino-purine, 2-iP + 0.1 mgL"-1 $\alpha$-naphthalene acetic acid, ANA) and "Nodes" $\left(0.5 \mathrm{mgL}^{-1} \mathrm{BAP}+0.1 \mathrm{mgL}^{-1} \mathrm{ANA}\right)$. "Reed" medium increased survival and recovery of shoot tips in both genotypes and techniques and decreased callus formation. However, it didn`t have a significant effect on genetic stability. "Senula" medium caused a higher genetic stability in the most unstable genotype, 'MEN 186'. 
To reduce oxidative damage during encapsulation-dehydration, and increase shoot tip recovery and maintain genetic stability, the effect of added antioxidants (ascorbic acid, vitamin E and glutathione) in the shoot tip preculture medium was studied. These treatments had no significant effect on both stability and recovery.

To better understand the events during the encapsulation-dehydration process, the effect of each step of the protocol on stability and recovery was evaluated separately. Moreover, the oxidation level was determined by quantifying malondialdehyde (MDA) formation and detecting free radical accumulation (using the thiobarbituric acid assay, and specific fluorescent probes, respectively). The oxidative stress was detected from the first steps and increased throughout the protocol until the immersion in liquid nitrogen. This was also reflected in the gradual decline of recovery and genetic stability. The use of antioxidants (ascorbic acid and vitamin E) in the shoot tip preculture medium had no effect in maintaining genetic stability; only vitamin E increased recovery in one of the steps studied (after desiccation). However, when ascorbic acid was used during the preculture or during the osmotic dehydration, a significantly decrease was observed in MDA formation and superoxide radical accumulation in most of the steps analyzed, although this reduction did not seem to have a direct effect on the genetic stability of recovered material. 


\section{ACRÓNIMOS Y ABREVIATURAS}

${ }^{1} \mathrm{O}_{2}$ : oxígeno singlete

2,4-D: ácido 2,4-diclorofenoxiacético

2-iP: 6-dimetilalilamino-purina

AA: ácido ascórbico

ABA: ácido abscísico

ABTS: ensayo del ácido 2-2’-azino-bis -(3-etilbenzotiazol-6- sulfónico)

ADN: ácido desoxirribonucleico

AFLP: Amplified Fragment Lenght Polymorphism o polimorfismos en la longitud de los fragmentos amplificados

AIA: ácido indol-3-acético

AIB: ácido indolbutírico

ANA: ácido $\alpha$-naftalenacético

ARN: ácido ribonucleico

BAP: 6-Bencilaminopurina

CAT: catalasa

CBD: Convenio sobre la Diversidad Biológica

CLMS: Confocal Laser Scanning Microscopy o microscopio láser confocal espectral

DAF: DNA Amplification Fingerprinting

DAF-2DA: diacetato 4,5-diaminofluorescina

DCF-DA: diacetato $2 \nmid 7 `$ - diclorofluoresceína

DHE: dihidroetidio

DMSO: dimetilsulfóxido

DMSO: dimetilsulfóxido Convenio

EPR: Electron Paramagnetic Resonance Spectroscopy

FAO: Organización de las Naciones Unidas para la Alimentación y Agricultura

GR: glutatión reductasa,

GSH: glutatión reducido

GSSG: glutatión oxidado

$\mathrm{H}_{2} \mathrm{O}_{2}$ : peróxido de hidrógeno, 
HNE: hidroxi-2-nonenal

HPLC: High Performance Liquid Chromatography o cromatografía de líquidos de alto rendimiento

IBPGR: "International Board for Plant Genetic Resources"

IPK: Leibniz Institute of Plant Genetics and Crop Plant Research

KIN: Quinetina

LN: liquid nitrogen (nitrógeno líquido)

M: peso molecular

MDA: malondialdehído

MS: medio Murashige y Skoog

MS: medio Murashige y Skoog (1962)

MSAP: Methylation Sensitive Amplified Polymorphism

NL: nitrógeno líquido

NO: óxido nítrico

$\mathrm{O}_{2}{ }^{\bullet-}$ : radical superóxido

$\mathrm{O}_{3}$ : ozono

$\mathrm{OH} \bullet$ : radical hidroxilo

POD: peroxidasa

PPFD: Photosynthetic Photon Flux Density o densidad de flujo de fotones fotosintéticos

PVPP: polivilpolipirrolidona

PVS: soluciones de vitrificación de plantas

PVS2: "Plant vitrification solution $\mathrm{n}^{\mathrm{o}}$ 2", solución de vitrificación de plantas $\mathrm{n}^{\mathrm{o}} 2$ (Sakai et al., 1990)

PVS3: "Plant vitrification solution $\mathrm{n}^{\circ} 3$ ", solución de vitrificación de plantas $\mathrm{n}^{\mathbf{0}} 1$ (Nishizawa et al., 1993)

RAF: Randomly Amplified DNA Fingerprinting

RAPD: Random Amplified Polymorphic DNA o amplificación arbitraria del ADN polimórfico

RFLP: Restriction Fragment Length Polymorphism o Polimorfismos en la Longitud de los Fragmentos de Restricción

RON: especies reactivas del nitrógeno

ROS: Reactive Oxygen Species o especies reactivas del oxígeno 
Sac: contenido de sacarosa

SOD: superóxido dismutasa

SSR: Short Sequence Repeats (microsatélites)

TBA: ensayo del ácido tiobarbitúrico

UPGMA: unweighted pair-group method analysis

ZEA: Zeatina 


\section{INTRODUCCIÓN}

\subsection{Conservación de recursos fitogenéticos de especies propagadas vegetativamente}

Recurso fitogenético es el material genético de origen vegetal que posee un valor real (económico) o potencial (científico o social) destinado a la alimentación y la agricultura, cuya diversidad genética puede usarse en la mejora o domesticación (Convenio sobre la Diversidad Biológica, CBD, 1992). También se define como la suma de todas las combinaciones de genes resultantes de la evolución de una especie. Comprenden desde especies silvestres con potencial agrícola hasta genes clonados (Jaramillo y Baena 2000). Esto implica que el material vegetal puede tener un valor económico o utilitario actual o futuro, siendo especialmente importante el que contribuye a la seguridad alimentaria. La diversidad fitogenética se ha visto reducida y reemplazada por la uniformidad de los cultivos (que facilita el manejo en el campo), y el abandono de especies y variedades menos rentables. Tan solo 30 cultivos proporcionan el $95 \%$ de las necesidades de energía alimentaria del ser humano, y solo cuatro de ellos - el arroz, el trigo, el maíz y las patatas - suministran más del $60 \%$ (FAO). La pérdida de variabilidad genética limita la capacidad de responder a nuevas necesidades y un incremento de la vulnerabilidad de los cultivos frente a cambios ambientales o aparición de nuevas plagas o enfermedades. La importancia de conservar la diversidad biológica es reconocida internacionalmente y actualmente 193 países forman parte del Convenio sobre la Diversidad Biológica, tratado en el cual se incluyen además la utilización sostenible de sus componentes y la participación justa y equitativa en los beneficios que se deriven de la utilización de los recursos genéticos (CBD, 1992). La FAO (Organización de las Naciones Unidas para la Alimentación y la Agricultura) ha desarrollado dos Planes de Acción Mundial para los Recursos Fitogenéticos para la Alimentación y la Agricultura en los años 1996 y 2011, para garantizar poder suplir las necesidades de alimentación de las generaciones futuras y tener la capacidad de adaptar cultivos a condiciones cambiantes del clima o aparición de enfermedades (Villalobos y Engelmann, 1995). Aunque el $90 \%$ de todas las accesiones actualmente presentes en bancos de germoplasma está representado por especies de interés alimentario, de fibra, medicinales y forestales (Bachetta et al. 2008), actualmente también se conservan especies silvestres emparentadas con las cultivadas (sus progenitores y 
otras especies más o menos relacionadas), ya que pueden contribuir con caracteres beneficiosos para los cultivos como, por ejemplo, aportar genes de resistencia a enfermedades o plagas (Maxted et al. 2008). En los bancos de germoplasma también se conservan especies amenazadas o en peligro de extinción (Towill 2002a).

Los recursos fitogenéticos se pueden conservar en sus hábitats naturales (in situ), o en condiciones diferentes (ex situ) dependiendo de las capacidades o recursos que se dispongan y de las características de la especie. En la conservación in situ las plantas se mantienen en sus ecosistemas naturales, expuestos a la selección natural y donde la variabilidad genética del germoplasma evoluciona con el ambiente. A las áreas de conservación in situ se les denomina "Reservas genéticas" o "Unidades de conservación de recursos genéticos" (Rivas y Barreta, 2001). Éstas pueden ser áreas protegidas y reservas naturales. Las especies cultivadas se pueden conservar en granjas o en los entornos en los que hayan desarrollado sus características distintivas (Cruz-Cruz et al. 2013). No obstante, debido a la destrucción o transformación de estos espacios puede haber pérdida de los materiales conservados, con lo que la utilización exclusiva de este sistema se vuelve insuficiente.

Como medida complementaria a la conservación in situ surgen los diferentes sistemas de conservación ex situ, orientados principalmente a resguardar el material genético y asegurar el mantenimiento de éste en el tiempo, en condiciones viables y con sus características genéticas originales (Jaramillo y Baena 2000). Con respecto a los sistemas de conservación, es posible mantener el germoplasma en forma de semillas, ya que constituyen la estructura más representativa y evolucionada de las plantas superiores para su perpetuación, siendo además el agente de dispersión más frecuente, eficaz y con mayor capacidad de regenerar a largo plazo una planta vascular completa. También se puede conservar polen y, en el caso de pteridófitas, esporas (Bachetta et al. 2008). Aquellas semillas que toleran las condiciones de almacenamiento a una baja humedad relativa y baja temperatura se denominan "ortodoxas"; en cambio, a aquellas semillas que no toleran estas condiciones, se les denomina "recalcitrantes". Éstas son semillas con un contenido inicial de humedad relativamente alto (15-25\%) y una manifiesta intolerancia a la desecación. Son frecuentes en especies forestales y de climas tropicales. Las semillas recalcitrantes no se pueden conservar con métodos "tradicionales" (bajo contenido de humedad y baja temperatura); en el caso de especies con este tipo de semillas hay que recurrir a la crioconservación o a mantener material vegetal en colecciones de campo o en cultivo in vitro (Villalobos y Engelmann 1995). De forma similar, 
el germoplasma de especies con propagación vegetativa puede conservarse en colecciones de campo, in vitro o crioconservado.

\subsection{Conservación de RRFF de especies con propagación vegetativa}

\subsubsection{Conservación en campo}

Las colecciones de plantas constituyen el método tradicional de conservación ex situ de los recursos fitogenéticos con propagación vegetativa. Bajo esta denominación se pueden considerar tanto los jardines botánicos como las colecciones de plantas en campo (Iriondo, 2001). En muchas circunstancias, las colecciones de campo o invernadero resultan costosas de mantener, requieren mucho espacio y resultan muy sensibles a los cambios ambientales. Además, estas colecciones pueden no ser en ocasiones una opción viable de conservación a largo plazo.

\subsubsection{Conservación in vitro}

La conservación in vitro constituye una parte esencial de la estrategia general para la conservación y el intercambio de recursos fitogenéticos a nivel mundial (Iriondo 2001). Los bancos in vitro de germoplasma conservan los recursos genéticos en condiciones controladas de laboratorio e involucran diversas técnicas de cultivo y almacenamiento in vitro (Iriondo 2001). Esta técnica ofrece la posibilidad de almacenar un elevado número y variedad de muestras en un área reducida y facilita el acceso a ellas para su evaluación (García-Águila et al. 2007). Permite una conservación de material a corto y medio plazo y, por sus condiciones de asepsia, se garantiza la sanidad de las muestras y en consecuencia facilitan el intercambio de materiales vegetales sanos (Sánchez-Chiang y Jiménez 2009). Se utiliza fundamentalmente en especies con semillas recalcitrantes, que producen semillas estériles, perennes con ciclos largos y que no producen semillas hasta cierta edad, con propagación vegetativa, o en especies donde su población se encuentra muy reducida y no se puede recolectar material para su conservación (Iriondo 2001). Se pueden utilizar órganos, tejidos, o células de plantas, que se cultivan en un medio aséptico, con condiciones de luz, y temperatura controladas. El proceso consta de cinco etapas: 1) elección y preparación de las plantas madres, para que se encuentren en condiciones fisiológicas y sanitarias óptimas; 2) establecimiento del cultivo, introduciendo los explantos, previamente sometidos a asepsia (generalmente con hipoclorito 
de sodio), en el medio de cultivo; 3) multiplicación, a partir de las yemas axilares o mediante la inducción de yemas adventicias; 4) elongación de los tallos y enraizamiento, y 5) aclimatación a condiciones ex vitro, mediante la exposición progresiva de las plantas a las condiciones de temperatura, luz y humedad existentes en el invernadero. El medio de cultivo más utilizado es el descrito por Murashige y Skoog (1962), aunque se han descritos diversos medios (B5 por Gamborg 1968; SH por Schenk y Hildebrandt 1972 y N6 por Chu et al. 1975, entre otros). Éstos están constituidos por componentes inorgánicos (macronutrientes y micronutrientes), sales minerales, vitaminas y aminoácidos, a los cuales se les debe adicionar azúcares (preferentemente sacarosa o fructosa), reguladores de crecimiento y un agente gelificante. Dentro de los reguladores de crecimiento los más utilizados son las citoquininas y auxinas. Las citoquininas provocan la división celular, multiplicación de brotes y proliferación de yemas axilares. Entre éstas se encuentran: 6-Bencilaminopurina (BAP), 6dimetilalilamino-purina (2-iP), Quinetina (KIN) y Zeatina (ZEA). Las auxinas inducen la elongación celular y el enraizamiento como el ácido indol-3-acético (AIA), el ácido $\alpha$-naftalenacético (ANA), el ácido 2,4-diclorofenoxiacético (2,4-D) y el ácido indolbutírico (AIB). Además, se pueden utilizar giberelinas, ácido abscícico y etileno. La elongación de los explantos puede realizarse sin reguladores de crecimiento, y para una mayor proliferación de brotes se puede utilizar BAP o KIN (Gaspar et al. 1996).

El cultivo in vitro con crecimiento lento es ampliamente utilizado por los bancos de germoplasma para lograr un almacenamiento a medio plazo de los explantos de especies tropicales, de cultivos con propagación vegetativa (por ejemplo, patata, plátano, yuca) o de especies amenazadas (Engelmann 2011). A través de modificaciones de las condiciones ambientales y/o cambios en el medio de cultivo se logra distanciar al máximo los subcultivos, (disminuyendo así el número de divisiones celulares), reduciendo las probabilidades de pérdidas por contaminación u otros errores técnicos, y también reduciendo el riesgo de que aparezcan cambios en el genotipo debidos a la inestabilidad genética de los explantos (Engelmann 1991). La técnica más utilizada es la disminución de la temperatura, alrededor de $4{ }^{\circ} \mathrm{C}$ para cultivos de zonas templadas y entre $10-15^{\circ} \mathrm{C}$ para especies tropicales (Keller et al. 2007), la cual se combina en ocasiones con una reducción en la intensidad lumínica, incluso llegando a mantener los cultivos en oscuridad. Las modificaciones en el medio de cultivo incluyen la dilución de elementos minerales, disminución en la concentración de sacarosa, cambios en la naturaleza y concentración de reguladores de crecimiento o la adición de compuestos osmóticamente activos (Engelmann 2011). 
Entre las ventajas de este sistema de conservación están el mantenimiento de una gran cantidad de explantos en una superficie relativamente pequeña, la facilidad de intercambio del material entre laboratorios e instituciones, la facilidad de multiplicación y la protección de los explantos frente a desastres naturales, plagas o enfermedades (Kameswara 2004). Sin embargo, el material está expuesto a desórdenes morfológicos y fisiológicos.

Una de las desventajas de la conservación in vitro es que pueden producirse variaciones de características morfológicas, bioquímicas, fisiológicas y/o genéticas (Chen et al. 1998). La aparición de esta inestabilidad (epi-)genética durante el cultivo de tejidos se denomina variación somaclonal. Según Larkin y Scowcroft (1981) el cultivo in vitro de material vegetal puede generar variabilidad genética y, por lo tanto, puede ser considerado como un "tratamiento" mutagénico. Estos cambios pueden ser genéticos o de expresión de genes, y ser transmitidos a la progenie. No se puede negar la importancia de este fenómeno que puede ser considerado deseable en la búsqueda de variaciones aplicadas a la mejora de las plantas, o como indeseable cuando se requieren plantas idénticas (Vázquez 2001), como es el caso de la micropropagación o conservación in vitro.

La variación somaclonal puede ser atribuida a diversos factores como los medios de cultivo, los reguladores de crecimiento, el tipo de explanto y la necesidad de subcultivos periódicos para mantener en buen estado el material vegetal. Por lo tanto, es importante manejar los factores que inducen variación somaclonal y evaluar posibles alteraciones, utilizando análisis citológicos y/o moleculares en los materiales conservados in vitro (Pierik 1987). Las causas directas de la variación somaclonal no están claras; podrían ser por un reordenamiento cromosómico, un sobrecruzamiento somático, el intercambio de cromátidas hermanas, una alteración de los nucleótidos por metilación, el silenciamiento o activación de genes por mutaciones ocurridas en regiones no codificantes (Tabares et al. 1991), o mitosis anormales debido a la presencia de hormonas. Sin embargo, probablemente sean varios los mecanismos implicados en la aparición de estas mutaciones (Phillips et al. 1994). A su vez, en el cultivo in vitro, las condiciones ambientales impuestas pueden ejercer un estrés que promueva estas mutaciones. La multiplicación por yemas axilares normalmente no origina variación somaclonal, mientras que cultivos que pasan por una fase de callo promueven una mayor tasa de mutación (Vázquez 2001). La conservación in vitro mediante crecimiento lento y, en especial, la crioconservación, disminuyen la probabilidad de que se produzca variación somaclonal. Con el crecimiento lento in vitro se reduce la actividad metabólica de los explantos, se retrasan los subcultivos, se disminuyen las probabilidades de pérdidas por 
contaminación u otros errores técnicos y se podrían disminuir el riesgo de que aparezcan cambios en el genotipo debidos a la inestabilidad genética del material vegetal.

\subsubsection{Crioconservación}

La crioconservación o almacenamiento de material genético en nitrógeno líquido (NL), es el método más seguro y, posiblemente, económico para mantener el germoplasma de plantas propagadas vegetativamente, de especies que poseen semillas recalcitrantes, de cultivos que no producen semillas o de genotipos estériles (Engelmann 2004). Esta técnica consiste básicamente en conservar, a largo plazo, el material vegetal a temperaturas ultra-bajas en nitrógeno líquido a $-196{ }^{\circ} \mathrm{C}$, o en su fase de vapor o en congeladores eléctricos (siempre por debajo de $-150^{\circ} \mathrm{C}$ ). Su principal ventaja radica en que a esas temperaturas el metabolismo celular queda prácticamente detenido (Engelmann 2004), lo que supuestamente conferiría una alta estabilidad genética.

El elemento crítico para la crioconservación exitosa es la prevención de la formación o crecimiento de hielo intracelular (Volk y Walters 2006) que podría dañar de forma irreversible las membranas celulares, destruyendo así su semi-permeabilidad (Panis y Lambardi 2005). Para evitar ese daño celular, tanto en las etapas de enfriamiento en NL como en el calentamiento para su recuperación, los explantos son sometidos previamente a una deshidratación, a un aumento de la concentración intracelular de solutos y a una crioprotección con la adición de diversas sustancias.

En general, la crioconservación es una técnica rápida y sencilla de realizar aplicable a diferentes tipos de tejidos, células y órganos de la planta (González-Benito et al. 2004; Reed 2008). El material crioconservado es almacenado en pequeños volúmenes, protegido de contaminaciones y requiere un escaso mantenimiento (Engelmann 2004), con lo cual se considera como una opción rentable para la conservación a largo plazo (Kameswara 2004). Esta técnica permite almacenar semillas (Berjak et al. 2000, Dussert et al. 2000), semillas sintéticas (Paulet y Engelmann 1994), meristemos y ápices (Escobar et al. 2000; GonzálezArnao et al. 2000; Hirai y Sakai 2000), polen (Inagaki 2000; Towill y Walters 2000), células (Reinhoud et al. 2000), callos y suspensiones celulares (Panis et al. 2000). Actualmente, hay más de 200 especies en las cuales se han desarrollado diferentes protocolos de crioconservación (Reed 2008). 
Sin embargo, varios obstáculos limitan una aplicación más amplia de la crioconservación, entre ellos la diversidad genética de las especies cultivadas que se manifiesta en una respuesta genotipo-dependiente a la crioconservación, y la falta de conocimiento sobre las causas asociadas a esa diferencia de respuesta y de regeneración (Johnston et al. 2007). Por otro lado, es importante determinar si el germoplasma recuperado después de la crioconservación es genéticamente idéntico al material de partida (Harding 2004). Aunque en diversos trabajos se ha recuperado material genéticamente estable (p.e. Reed 2002, Castillo et al. 2010; Salaj et al. 2011; Ai et al. 2012; Matsumoto 2013), en otros se han observado cambios (Martín and González-Benito 2005; Martín et al. 2011; Kaity et al. 2008, 2009; Zeliang et al. 2010; Mikuła et al. 2011). Sin embargo, es importante separar la posible variación inducida en la crioconservación de la provocada por la formación de callo durante la regeneración de los explantos después de su crioconservación, ya que este hecho sí podría causar mutaciones (Reed 2002; Chang y Reed 1999).

En muchos protocolos de crioconservación se utiliza un paso previo de pre- aclimatación en frío, favoreciendo la supervivencia de los explantos (González-Benito 2004). Consiste en mantener los explantos o el material de partida, generalmente, durante algunas semanas a temperaturas frías (p.e. $4^{\circ}$ o $10^{\circ} \mathrm{C}$ ) o alternas (p.e. $22-25^{\circ} \mathrm{C}$ en la fase de luz y $-1{ }^{\circ} \mathrm{C}$ en la fase de oscuridad). En el caso de algunas gramíneas, la aclimatación en frío es esencial para la crioconservación de ápices caulinares ya que además de aumentar la tolerancia a las bajas temperaturas, aumenta su tolerancia a la deshidratación (Chang et al. 1999). También se ha obtenido una mayor regeneración tras la crioconservación en manzano (Kushnarenko et al. 2009), peral (Chang et al. 2000), menta (Senula et al. 2007), entre otras especies. En el caso de algunas especies de Rubus este tratamiento se debe combinar con la adición de ácido abscísico (ABA) para obtener una mayor supervivencia (Reed, 1993). Barroco y col. (2012) desarrollaron un tratamiento en el que reemplazan la aclimatación al frío por el pretratamiento de los ápices en un medio con alta concentración de sacarosa durante siete días, consiguiendo el mismo efecto en el aumento de la supervivencia de especies de Prunus crioconservadas por vitrificación.

El tamaño de los explantos es un factor importante para el éxito de la crioconservación. Generalmente ápices pequeños (1-2 $\mathrm{mm}$ de largo) e intermedios (3-4 mm) pueden alcanzar porcentajes de regeneración comparables a los de los controles no crioconservados. En contraste, ápices más grandes (5-6 mm) tienen una fuerte disminución en el porcentaje de regeneración (Engelman 2014). 
Las técnicas de crioconservación utilizan dos posibles metodologías denominadas "crioconservación clásica" o por "enfriamiento controlado o lento", y las "nuevas metodologías" o por "vitrificación". La primera se basa en un enfriamiento lento hasta alcanzar $-40{ }^{\circ} \mathrm{C}$ y posteriormente un enfriamiento rápido por inmersión en NL. Generalmente es complejo de operar y requiere el uso de equipos caros y sofisticados que programen el enfriamiento (Engelmann 2004). Utilizando esta metodología se forman cristales de hielo en las soluciones extracelulares y se produce la pérdida de agua por parte de las células. Previamente al enfriamiento se llevan a cabo tratamientos de precultivo o aclimatación de los tejidos con sustancias crioprotectoras, usualmente dimetil sulfóxido (DMSO) combinado con azúcares, glicerol o polietilenglicol (Towill 2002a), que evitan los daños provocados tanto por la cristalización o formación de hielo dentro y fuera de las células, como la toxicidad por la acumulación de solutos durante el proceso de enfriamiento.

La segunda metodología de crioconservación se basa en los procedimientos de vitrificación, donde la solidificación o vitrificación de las soluciones de los tejidos vegetales durante el proceso de enfriamiento impiden que se formen cristales de hielo (Benson, 2008). Las soluciones (tanto intracelulares como extracelulares) pasan a un estado vítreo, definido como la solidificación de un líquido no por cristalización sino por un aumento extremo de su viscosidad durante el enfriamiento (Fahy et al. 1984). Esta extrema viscosidad además detiene todas las reacciones químicas que requieren difusión molecular, por lo que permite una estabilidad y latencia de los explantos a lo largo del tiempo (Burke 1986). Para esto se debe realizar una reducción del contenido de agua y osmoprotección de los explantos con medios con sacarosa y/o glicerol. Después de la reducción del contenido de agua de las soluciones intra- y extracelulares y se lleva a cabo un enfriamiento ultra-rápido en NL, donde la velocidad de enfriamiento puede ser entre 0,1 y $10{ }^{\circ} \mathrm{C} \mathrm{s}^{-1}$ (generalmente por inmersión directa en NL). La reducción del contenido de agua se puede llevar a cabo por exposición de los tejidos a mezclas de sustancias crioprotectoras a altas concentraciones, como por ejemplo las llamadas PVS2 ("Plant Vitrification Solution 2"; Sakai et al. 1990) y PVS3 (Nishizawa et al. 1993), o a una desecación física. En el primer caso la técnica de crioconservación se denomina "vitrificación en sentido estricto" o simplemente "vitrificación" (Sakai et al. 1990). En el segundo caso, si los explantos se encapsulan previamente a la desecación en cuentas de alginato, se denominan “encapsulación-deshidratación” (Fabre y Dereuddre 1990). Existen además protocolos en los que se combinan ambas estrategias: "encapsulación-vitrificación" (Matsumoto et al. 1995). En el caso de utilizar soluciones vitrificantes, y colocar el material a 
crioconservar en una lámina de papel de aluminio o una placa de aluminio se denominan vitrificación-droplet (Schäfer-Menuhr et al. 1997) y vitrificación-cryo-plate (crio-placa) (Yamamoto et al. 2011), respectivamente. No todos los genotipos responden de manera similar ante técnicas de crioconservación diferentes, y pequeñas variaciones en los procedimientos pueden provocar tasas de supervivencia variables; por esto es necesario encontrar un protocolo adecuado para cada genotipo de interés.

El primer procedimiento de vitrificación fue descrito por Sakai y col. en 1990 en células nucelares de Citrus sinensis, las cuales eran deshidratadas utilizando la solución PVS2, antes de la inmersión directa en nitrógeno líquido. La función de la PVS2 es eliminar el agua celular, cambiar las características de congelación celular, limitar la cristalización de hielo y, además, tiene componentes que permeabilizan las células (Volk et al. 2006). Según describe Sakai y col. (2008), los pasos de esta técnica serían en primer lugar un precultivo de los meristemos, extraídos desde las plantas a crioconservar, en un medio rico en sacarosa (0,3-0,7 M de sacarosa), ya que la acumulación de azúcares aumenta la estabilidad de las membranas ante condiciones de extrema deshidratación (Crowe et al. 1984). En algunos procedimientos antes del precultivo se realiza una aclimatación del material vegetal en frío. Normalmente el precultivo no es suficiente preacondicionamiento antes de la vitrificación, por lo que se realiza una osmoprotección de los tejidos con una solución de carga (“loading solution") compuesta principalmente por glicerol y sacarosa. Esto aumenta la tolerancia a la deshidratación de los tejidos por un incremento de la osmolaridad de las células, minimizando así el daño osmótico causado por la solución de vitrificación. Una vez retirada esta solución se inicia la etapa de deshidratación y crioprotección celular con soluciones vitrificantes (PVS2 o PVS3) teniendo precaución en los tiempos y dosis de éstas para no provocar daños por toxicidad química o exceso de estrés osmótico. El crioprotector penetra las células y estabiliza las proteínas y membranas; sin embargo, su modo de acción va a depender del tipo de célula, especie, temperatura y los otros componentes de la solución (Volk et al. 2006). A continuación, el enfriamiento debe ser muy rápido, por lo que se realiza una inmersión directa en NL. Para recuperar el material crioconservado se realiza un calentamiento rápido, normalmente en baño de agua caliente a $40{ }^{\circ} \mathrm{C}$ y después se deben lavar o diluir los restos de solución vitrificante del material vegetal. Generalmente se utiliza la solución de lavado constituida por el medio líquido suplementado con 1,2 M sacarosa (Sakai y Engelmann 2007). Finalmente se realiza el cultivo en medio de recuperación, donde comenzarán a formarse brotes normales tras 3-4 semanas después del establecimiento. En esta etapa es fundamental 
evitar la formación de callo ya que potencialmente aumenta la frecuencia de variación genética (Sakai et al. 2008), por lo suele ser recomendable evitar el uso de auxinas en el medio de recuperación (Uchendu y Reed 2008). La técnica de vitrificación tiene la ventaja de que se requiere en un corto período de tiempo para aplicarla. Sin embargo, es difícil de realizar simultáneamente a un gran número de muestras, ya que la duración de los pasos sucesivos del protocolo de vitrificación es a menudo muy corta y requieren una duración muy precisa, además los explantos de tamaño pequeños son difíciles de manipular. Esta técnica ya es utilizada en más de 120 especies (Sakai y Engelmann 2007).

La encapsulación-deshidratación fue desarrollada por Fabre y Dereuddre (1990) para la crioconservación de ápices de peral y patata. Su principio se basa en la producción de semillas sintéticas encapsulando los explantos en cápsulas polimerizadas de alginato cálcico (Redenbaugh et al. 1986), que son precultivadas en un medio líquido con altas concentraciones de sacarosa (0,5-1,25 M); en algunas especies también se agregan otros osmoprotectores en el medio como glicerol (Matsumoto y Sakai 1995). Posteriormente las cuentas son deshidratadas colocándolas en la corriente de aire de una cámara de flujo laminar o en contenedores con gel de sílice seco (González-Arnao y Engelmann 2006), por lo que gran parte del agua congelable es retirada de las células. La vitrificación de las soluciones celulares tiene lugar durante la rápida exposición al NL (Engelmann et al. 2008) evitando así la letal cristalización intracelular (Engelmann 1997). Esta técnica ha sido utilizada con éxito para la crioconservación de más de 70 especies diferentes, incluyéndose entre éstas la menta (Towill 1990). El procedimiento, en general, incluye un preacondicionamiento del material inicial, generalmente a bajas temperaturas en el caso de plantas tolerantes al frío, o cultivándolo en altas concentraciones de sacarosa (Engelmann et al. 2008). La recuperación de los explantos crioconservados se hace utilizando el calentamiento rápido en un baño de agua caliente, p.e. a $40-45{ }^{\circ} \mathrm{C}$ por 2-3 min. En algunos casos las cuentas pueden ser rehidratadas en medio de cultivo líquido (Chang et al. 1999) o lentamente a temperatura ambiente, ya que no hay riesgo de recristalización (González-Arnao y Engelmann 2006). También suele ser beneficioso para la recuperación de estructuras organizadas como ápices caulinares, cultivarlos durante unos días en oscuridad ya que previene o disminuye la fotooxidación de los explantos crioconservados (González-Arnao y Engelmann 2006). Una desventaja de esta técnica es que requiere de tiempos más prolongados para llevarla a cabo, sin embargo, los explantos encapsulados son muy fáciles de manipular, gracias al 
relativamente gran tamaño de las cuentas de alginato. Se han desarrollado protocolos de criconservación para más de 20 especies con esta técnica (Sakai y Engelmann 2007).

La encapsulación-vitrificación es una mezcla de las técnicas descritas anteriormente. Las cuentas de alginato son polimerizadas en una solución con cloruro de calcio suplementada con glicerol y sacarosa. Así se realiza la encapsulación y osmoprotección de los explantos de forma simultánea. Después, las cuentas son deshidratadas en la solución vitrificante (p.e. PVS2) y finalmente introducidas directamente en NL. Para la recuperación se realiza un calentamiento rápido en baño de agua caliente. Por lo tanto, combina las ventajas de la vitrificación (rapidez de la aplicación) y de la encapsulación (facilidad de manipulación de los explantos encapsulados).

La vitrificación-droplet (gotita) es una modificación de la vitrificación. El procedimiento es el mismo, sólo que para la inmersión en NL los explantos se disponen en pequeñas gotas de PVS2 en una lámina de papel aluminio. Para la recuperación se procede de igual manera que en el proceso normal de vitrificación, si la lámina de aluminio se encuentra dentro de un criovial, o se calienta la lámina en la solución de lavado a temperatura ambiente (Sakai y Engelmann 2007). Es una técnica rápida y a su vez de manipulación más fácil que una vitrificación normal (Kim et al. 2006). Es utilizada en menta, patata, ajo, fresa, crisantemo, batata, caña de azúcar y tomillo entre otros (Sakai y Engelmann 2007).

La crioconservación mediante la utilización de cryo-plate (crio-placa) fue desarrollada con éxito en ápices de crisantemo el año 2011 por Yamamoto y col. Se ha aplicado utilizando soluciones vitrificantes (vitrificación-cryo-plate o V-cryo-plate) o la deshidratación (deshidratación-cryo-plate o D-cryo-plate). En la técnica V-cryo-plate los ápices son colocados en la placa (cryo-plate) de aluminio (p.e. $7 \mathrm{~mm}$ x $37 \mathrm{~mm}$ x 0,5 mmcon 10 pocillos), embebidas en alginato y éste polimerizado en una solución con cloruro de calcio. La osmoprotección se realiza mediante la inmersión de la placa en solución de carga. Para la deshidratación, la solución de carga es reemplazada con una solución de vitrificación. Después de la inmersión rápida en NL, los ápices se recuperan por la inmersión de las crioláminas en una solución de sacarosa $1 \mathrm{M}$. En la técnica D-cryo-plate se realiza el mismo procedimiento que el anterior hasta la osmoprotección; en este caso la deshidratación se realiza en la cámara de flujo laminar durante 2- $3 \mathrm{~h}$ hasta alcanzar contenido de humedad del 25 a $27 \%$ sobre peso fresco (Niino et al. 2013). Ambos procedimientos pueden facilitar el crioalmacenamiento a gran escala en los bancos de germoplasma. Se han utilizado en caña de 
azúcar (Rafique et al. 2015), dátiles (Salma et al. 2014), caqui (Matsumoto et al. 2015), y menta (Yamamoto et al. 2012), entre otros.

\subsection{Estabilidad genética en el cultivo in vitro y la crioconservación}

En la conservación ex situ es de vital importancia mantener la constitución genética del material original (Keller et al. 2010). Sin embargo, es frecuente encontrar publicaciones que mencionan la aparición de fenotipos diferentes tras su cultivo in vitro (Vázquez, 2001). Como se mencionó anteriormente (ver apartado 1.1.2), Larkin y Scowcroft (1981) lo describieron como una nueva forma de obtener variabilidad genética y lo llamaron variación somaclonal, definiéndolo como toda variación genética o epigenética que se genera durante el cultivo in vitro de plantas (cultivos celulares de tejidos u órganos) que provenga de células somáticas. Puede manifestarse como variación en: la morfología de la planta, el número de cromosomas, la acumulación de mutaciones, los niveles de expresión génica, perfiles de proteínas y los cambios moleculares en las secuencias de ADN (Harding 2004). Se han propuesto varios mecanismos moleculares que pueden promover estos cambios y que pueden aparecer con más o menos frecuencia dependiendo del genotipo, (Vázquez 2001). Tales mecanismos moleculares incluyen la alteración de la capacidad celular para reparar el ADN dañado o mutado, la alteración de los genes de los mecanismos de control del ciclo celular y los cambios en el patrón de metilación del ADN. Cuando la variación somaclonal es heredable se asocia con reordenamientos cromosómicos, deleciones y mutaciones puntuales, y cuando la variación es epigenética, puede dar lugar a un cambio en la expresión de los genes, reversible o no, que puede estar asociado a alteraciones en los patrones de metilación del ADN (Sánchez-Chiang y Jiménez 2009; Neelakandan y Wang 2012). En el cultivo in vitro hay factores que podrían inducir esta inestabilidad, como la desdiferenciación celular provocada en la formación de callo, la utilización de material envejecido, la realización de subcultivos sucesivos, el estrés generado a las plantas al someterlas a condiciones artificiales. En el caso de la crioconservación, el material conservado en NL no tiene prácticamente actividad metabólica, por lo que no deberían producirse cambios en la estabilidad genética; sin embargo, la exposición de los tejidos previamente a estreses físicos, químicos y fisiológicos, que pueden producir daño oxidativo y la formación de radicales libres, pueden provocar lesiones cuyos efectos en el genoma de un organismo son a menudo desconocidos (Harding 2004). 
La variación somaclonal puede detectarse por diferentes tipos de marcadores: morfológicos, bioquímicos y moleculares. Los marcadores morfológicos fueron los primeros en utilizarse, corresponden a características fenotípicas de fácil visualización. Pueden ser cualitativos o cuantitativos, de los diferentes órganos de las plantas, y determinadas visualmente o métricamente como la forma, color, tamaño o altura (Piña-Escutia et al. 2010). Establecen las bases para identificar y diferenciar variedades, pero tienen muchas limitaciones, ya que la expresión o el fenotipo están sujetos a las variaciones ambientales; su obtención es tardía ya que son evaluables cuando las plantas llegan a edad adulta y es un método muchas veces subjetivo (Rani y Raina 2000).

Los marcadores bioquímicos se basan en los polimorfismos presentes en ciertas proteínas solubles como isoenzimas, proteínas de reserva o metabolitos secundarios, que son comparadas mediante distintas técnicas de electroforesis y posterior tinción. Dentro de este grupo, los isoenzimas han supuesto la técnica predominante. Se pueden definir como diferentes formas moleculares de un enzima presentes en un mismo individuo y que catalizan una misma reacción, los enzimas pueden estar codificados por un locus o por varios loci. En general son técnicas de fácil implementación en los laboratorios, con metodologías sencillas, rápidas y de bajo coste. Sin embargo, los resultados son difíciles de interpretar y representan una baja porción del genoma. Los metabolitos secundarios son compuestos de naturaleza química diversa. Estos compuestos son característicos de una especie o un genotipo, derivados del metabolismo secundario de las plantas, que pueden ser terpenos (pigmentos o aceites esenciales), compuestos fenólicos (flavonoides, lignina y taninos), glicósidos (saponinas y glucosinolatos) y alcaloides (Ávalos y Pérez-Urria 2009). La expresión de la producción de metabolitos secundarios se altera fácilmente por factores externos como los niveles de nutrientes y factores de estrés, entre otros, por lo tanto, es importante tomar medidas para garantizar que la influencia del medio ambiente sea mínima. Por otra parte, los cambios en el nivel de algunos metabolitos resultan de diferentes edades y estados fisiológicos de las plantas.

Los marcadores moleculares son ampliamente utilizados en genética humana, vegetal, animal y microbiana. Permiten detectar variaciones (polimorfismos) en la secuencia del ADN entre individuos, modifiquen éstos o no su fenotipo. Entre ellos podemos encontrar aquellos que se basan en la hibridación del ADN y aquellos basados en la PCR (Polymerase Chain Reaction o Reacción en Cadena de la Polimerasa). Un buen marcador debe ser: altamente polimórfico o variable dentro o entre especies, independiente a los efectos ambientales, 
codominante, de rápida identificación y análisis sencillo, y de posible detección en los estadios tempranos del desarrollo de la planta.

\subsubsection{Marcadores basados en la hibridación del ADN}

Los marcadores basados en la hibridación más utilizados son RFLP (Restriction Fragment Lenght Polymorphism, o Polimorfismos de la Longitud de los Fragmentos de Restricción). Fueron los primeros marcadores en desarrollarse. Detectan polimorfismos entre individuos, generando fragmentos de ADN de diferente longitud, cortados o digeridos en sitios específicos por enzimas de restricción que reconocen secuencias de 4 a 6 pares de bases. Los fragmentos se separan por electroforesis, luego se transfieren por capilaridad a membranas de nitrocelulosa o de nylon (transferencia tipo Southern blot), y se hibridan con sondas específicas marcadas radioquímicamente o quimioluminiscentes. Al colocar una placa radiográfica sobre ella se revelan las bandas. Son marcadores codominantes, altamente reproducibles. Sus desventajas son que se necesitan grandes cantidades de ADN de gran calidad, se necesita trabajar con radioactividad (aunque en el caso de la quimioluminiscencia ya no es necesario) (Jaligot et al. 2002). Se ha utilizado, por ejemplo, para evaluar la estabilidad genética del ARN ribosomal en ápices de patatas cultivadas en crecimiento lento y crioconservadas (Harding 1991), en la estabilidad del ADN de plantas de caña de azúcar regeneradas de callos y suspensiones celulares cultivadas in vitro y de suspensiones celulares y protoplastos crioconservados (Chowdhury y Vasil 1993; Paulet et al. 1993), en crioconservación de cultivos embriogénicos de Picea glauca (Cyr et al. 1994).

\subsubsection{Marcadores basados en la PCR}

La reacción en cadena de la polimerasa o PCR es una técnica desarrollada por Kary Banks Mullis en 1986, para la síntesis de grandes cantidades de un fragmento de ADN a partir de una sola copia (Hongbao 2005). Consiste en la amplificación de un segmento particular de ADN, al que se hibrida en sus flancos un cebador o primer, mediante la acción de un enzima ADN polimerasa termoestable. En primer lugar, ocurre una desnaturalización del ADN por ruptura de los puentes de hidrógeno, mediante una incubación a una temperatura de alrededor de $90-95{ }^{\circ} \mathrm{C}$, por un minuto, donde se separan las dos cadenas del ADN. En segundo lugar, ocurre la hibridación de las cadenas desnaturalizadas del ADN con los cebadores (ADN 
sintético de cadena sencilla), a una temperatura que facilita el apareamiento de las bases nitrogenadas complementarias de ambos. Esta temperatura depende de la temperatura de fusión (Tm) de los cebadores y su longitud (oscila entre 35 y $65{ }^{\circ} \mathrm{C}$ ). Finalmente, la polimerasa extiende la longitud de los cebadores complementando la cadena de ADN original, añadiendo los nucleótidos correspondientes en el orden que dicta la secuencia, ésto se realiza a $72{ }^{\circ} \mathrm{C}$, temperatura para la que la polimerasa alcanza su mayor actividad. Con la repetición de esta secuencia o ciclos se logra un aumento exponencial del fragmento original de ADN hasta llegar a millones de copias de la secuencia deseada. Este procedimiento se realiza automáticamente en un termociclador. La detección del producto amplificado se realiza mediante electroforesis, colocando el ADN amplificado en un gel (de agarosa o poliacrilamida) que es sometido a un gradiente eléctrico, del electrodo negativo al positivo, lo que provoca la movilidad de la muestra, con una velocidad de migración inversamente proporcional al tamaño de los fragmentos amplificados, y su separación por tamaños en el gel. La visualización de las bandas se puede realizar por tinción con bromuro de etidio con luz ultra violeta o con tinción de plata, fluorescencia y radiactividad. Actualmente también es posible detectar los productos amplificados mediante técnicas de secuenciación, para ello es necesario marcar con algún fluorocromo los cebadores utilizados en la amplificación.

Son muchos los marcadores moleculares que han sido desarrollados a partir de la PCR, entre los más empleados se encuentran: RAPD, AFLP y microsatélites.

\subsubsection{Marcadores RAPD}

La amplificación arbitraria del ADN polimórfico o RAPD (Random Amplified Polymorphic DNA) fue desarrollada por dos laboratorios simultáneamente (Welsh y McClelland 1990; Williams et al. 1990). La técnica se basa en la utilización como cebadores de secuencias arbitrarias y cortas (nomalmente 10 nucleótidos) con un contenido de al menos $50 \%$ de C-G, que pueden hibridar con el ADN analizado en varios sitios a lo largo del genoma (Waugh y Powell 1992). A partir de esta unión se sintetiza un fragmento continuo de ADN del que, por medio de la PCR, se obtiene una infinidad de copias en pocas horas. De esta manera los fragmentos o productos de la amplificación pueden ser separados por electroforesis en geles de agarosa y visualizados por tinción con bromuro de etidio, bajo luz ultra violeta. Los polimorfismos pueden resultar de cualquier cambio en la secuencia o sitio de unión del cebador (mutación puntual), lo cual impide que el cebador se una a la cadena, o 
también pueden ser el producto de cambios que alteren el tamaño del producto final (Weising et al. 1995)

Entre las ventajas de estos marcadores se encuentran que no se necesita un conocimiento previo de la secuencia de ADN del organismo, por lo que resulta especialmente interesante en especies silvestres o poco estudiada, no requiere de grandes cantidades de ADN y es además una técnica económica y rápida que permite el análisis de un gran número de muestras. Como principales desventajas está la naturaleza dominante de los marcadores que se obtienen (Waugh y Power 1992), que la presencia de amplificaciones de bandas diferentes del mismo peso molecular son imposibles de distinguir, y la baja reproducibilidad de resultados entre laboratorios, en el sentido de que pequeñas modificaciones en la técnica como, por ejemplo, en la concentración de ADN inicial, el modelo de termociclador, el origen de la polimerasa termoestable, etc., pueden alterar el patrón de fragmentos de ADN generados (Martínez, 2004).

En la crioconservación hay muchos estudios que utilizan estos marcadores para evaluar la estabilidad genética de diversas especies. Marco-Medina y Casas (2013) estudiaron la estabilidad en Thymus moroderi crioconservado por vitrificación y encontraron que $34 \%$ de las muestras eran variables. Aronen y col. (1999) probaron diferentes crioprotectores en la vitrificación de Abies cephalonica y evaluaron la estabilidad en muestras crioconservadas y en aquellas que recibieron todos los pasos de la crioconservación menos la inmersión en NL. Encontraron una variabilidad genética considerable en aquellas muestras tratadas con DMSO sin inmersión en NL, indicando que los crioprotectores pueden ser un riesgo para la estabilidad genética, pero que ésta era superior tras la crioconservación. Mandal y col. (2008) compararon las técnicas de vitrificación y encapsulación-deshidratación en Discorea rotundata, resultando el material crioconservado estable cuando se comparaba con las muestras control de cultivo in vitro. Deverno y col. (1999) evaluaron clones de cultivos embriogénicos de Picea glauca crioconservados durante 3-4 años y encontraron variabilidad en los cultivos tras 2 y 12 meses de su recuperación post-crioconservación, pero no en el caso de embriones inmediatamente regenerados. Helliot y col. (2002) evaluaron por medio de RAPD y ALFP la estabilidad en Prunus ferlenain, y no encontraron diferencias entre muestras crioconservadas y control. Matsumoto y col. (2013) evaluaron la estabilidad en ápices de wasabi crioconservados por vitrificación y almacenados a $-150{ }^{\circ} \mathrm{C}$ durante 10 años. Se evaluaron también ápices almacenados por $2 \mathrm{~h}$ en NL, ápices tratados con PVS2 y controles sin tratamientos. Se evaluaron durante 24 meses las plantas formadas a partir de 
ápices crioconservados, mediante marcadores morfológicos, bioquímicos y moleculares (RAPD). Se encontraron diferencias en la composición química a los 16 meses que, después de 24 meses de cultivo, habían desaparecido. No se encontraron diferencias significativas con los marcadores morfológicos ni moleculares. Martín y González-Benito (2005) compararon la estabilidad genética en ápices de crisantemo después de su crioconservación mediante las técnicas de vitrificación y de encapsulación-deshidratación. Se analizaron la planta madre, las hojas de vástagos cultivados in vitro de donde se extrajeron los ápices para la crioconservación, y los vástagos regenerados a los 30 y 90 días desde su recuperación después de la crioconservación. Sólo en los vástagos regenerados a partir de las muestras crioconservadas mediante encapsulación-deshidratación se encontraron polimorfismos. Mediante marcadores RAPD, se estudió la identidad genética de vástagos de tres genotipos de menta ('MEN198', 'MEN186' y 'MEN166') conservados en el banco de germoplasma del IPK (Leibniz Institute of Plant Genetics and Crop Plant Research), en la colección de campo, en cultivo in vitro con crecimiento lento y crioconservados por vitrificación-droplet (Martín et al. 2013). 'MEN198' fue el único genotipo que mantuvo su estabilidad independientemente del proceso de conservación. Las muestras de campo de los genotipos 'MEN186' y 'MEN166' se componían de diferentes genotipos, y ninguno de ellos se correspondía al material conservado in vitro ni crioconservado, donde sí mostraron un genotipo único para cada accesión, con lo que se demostraba la dificultad del manejo de colecciones de campo en especies que producen estolones.

\subsubsection{Marcadores AFLP}

La detección de polimorfismos en la longitud de los fragmentos amplificados o AFLP (Amplified Fragment Lenght Polymorphism) fue descrita por Vos y col. (1995), y es considerada como una combinación entre RFLP y PCR, con la especificidad, la resolución y el poder de muestreo del uso de enzimas de restricción, y la velocidad y practicabilidad de la detección de polimorfismos mediante la PCR (Martínez, 2004). Involucra dos enzimas de restricción para la digestión del $\mathrm{ADN}$ (como, por ejemplo, EcoRI y Msel) que reconocen secuencias específicas de ADN y divide los enlaces fosfodiéster del material genético en dichos sitios, denominados sitios de restricción (Garbus et al. 2004). Se utiliza una enzima de restricción de corte raro (como EcoRI), que reconoce de 6-8 pares de base (pb) y otra de corte frecuente (como MseI) que reconoce $4 \mathrm{pb}$ que, al tener muchos puntos de reconocimiento en 
el genoma, dará lugar a un número mayor de fragmentos. Luego ambos extremos se ligan con adaptadores o fragmentos de ADN de cadena doble, de 20-30 pares de bases para así proveerlos de una secuencia conocida para realizar la amplificación. Para generar copias de los fragmentos obtenidos se realiza una pre-amplificación utilizando cebadores de aproximadamente 20 nucleótidos que contienen una secuencia específica complementaria a la secuencia de los adaptadores y, además, un nucleótido selectivo adicional de secuencia arbitraria en su extremo 3'. El producto de esa pre-amplificación es utilizado para una segunda amplificación utilizando cebadores específicos (uno de ellos marcado radiactiva o fluorescentemente), y que poseen uno o dos nucleótidos adicionales al anterior, en función de las secuencias de los sitios de restricción de las enzimas y de los adaptadores empleados. Éstos seleccionan sólo los fragmentos en cuyos extremos se encuentran los cortes de ambas enzimas. Los resultados se visualizan en geles de poliacrilamida o pueden ser secuenciados automáticamente. Las ventajas de estos marcadores son que no requieren información previa sobre el ADN a estudiar, detectan una gran cantidad de loci, son altamente repetitivos y presentan un alto poder de detección de variabilidad genética. Las desventajas que presentan son el hecho de que sean marcadores dominantes, es una técnica costosa y requiere un equipamiento que utiliza radioactividad o secuenciadores (Masuelli, 1999).

Diversos trabajos han utilizado los AFLPs como marcadores para detectar la estabilidad genética después de la crioconservación. Martín y col. (2011) evaluaron la estabilidad genética en ápices de crisantemo en cada paso de la crioconservación por encapsulacióndeshidratación, mediante marcadores RAPD y AFLP. Se encontró variación genética en todas las etapas del procedimiento y se concluyó que no sólo en la crioconservación (almacenamiento en NL) los explantos pueden sufrir estrés, sino que a lo largo de todo el proceso. Peredo y col. (2008) analizaron por RAPD y AFLP la posible variabilidad entre plantas cultivadas en invernadero, vástagos procedentes de cultivo in vitro en crecimiento lento a baja temperatura, y de ápices crioconservados por enfriamiento lento, no encontrando diferencias entre ellas. Hao y col. (2001) analizaron, mediante AFLP, vástagos procedentes de ápices de manzano crioconservados por encapsulación-deshidratación. No se encontró variabilidad entre muestras crioconservadas y las muestras in vitro. Turner y col. (2001) compararon vástagos procedentes de cultivo in vitro, de cultivo in vitro en crecimiento lento y de ápices crioconservados por encapsulación-deshidratación de Anigozanthos viridis, y no encontraron diferencias. El año 2003 Wilkinson y col. evaluaron en Cosmos atrosanguineus material de cultivo in vitro y ápices crioconservados por encapsulación-deshidratación. Por 
microscopía electrónica se encontró daño celular en los ápices durante la inmersión en NL; sin embargo, no hubo variabilidad genética entre las muestras.

\subsubsection{Microsatélites}

Los microsatélites o secuencias simples repetidas (Short Sequence Repeats, SSR); son regiones hipervariables del $\mathrm{ADN}$, de secuencia corta (de 1 a 5 pb) repetidas entre 10 y 100 veces (Martínez, 2004) que generalmente se encuentran en zonas no codificantes del genoma. Las secuencias son amplificadas por PCR utilizando cebadores específicos para las zonas que flanquean al tándem de estas secuencias repetidas. Para visualizarlas se puede utilizar la electroforesis en geles de acrilamida y tinción con plata o radiactivamente, o se pueden secuenciar automáticamente utilizando un cebador marcado por un fluoróforo. La variación en el número de estas repeticiones en tándem (tamaño de microsatélite amplificado) dan origen al polimorfismo. Para su desarrollo se requiere el conocimiento previo de las regiones flanqueantes, mediante el uso de genotecas. Son marcadores codominantes, altamente repetitivos y altamente polimórficos. Son utilizados en el estudio de ligamiento genético en plantas, en estudios poblacionales y en la identificación de variedades (Gupta et al.1994).

Castillo y col. (2010) analizaron por AFLP y SSR material crioconservado durante 12 años de arándano, frambuesa y de Rubus grabowski. También analizaron vástagos cultivados in vitro y material de campo. El material crioconservado, tras su recuperación, fue cultivado in vitro, aclimatado y cultivado en campo. Morfológicamente las plantas crioconservadas parecían más vigorosas y con hojas, frutos y semillas más grandes. Se realizaron análisis mediante marcadores moleculares del material crioconservado, inmediatamente después de su recuperación y siete meses después, y se compararon con la planta madre. Se detectaron polimorfismos en aquellas muestras crioconservadas a los 7 meses de recuperación. Esas plantas fueron analizadas tras su cultivo en campo y ya no se encontraron diferencias. Los autores sugieren que la naturaleza transitoria de los cambios detectados debe ser considerada cuando se estudia la estabilidad genética. Sisunandar y col. (2010) estudiaron la estabilidad de embriones cigóticos de coco después de su crioconservación en comparación con embriones control (sin crioconservar). Se realizó un estudio morfológico y de variabilidad genética mediante marcadores SSR y se evaluó la tasa global de metilación del ADN. No se encontraron diferencias con ninguno de los marcadores utilizados. Condello y col. (2009) analizaron, mediante RAPD y SSR, ápices de peral silvestre crioconservados por 
encapsulación-deshidratación, no encontrándose polimorfismos. Se evaluaron mediante AFLP y SSR, embriones somáticos de alcornoque (Fernandes et al. 2008) crioconservados mediante encapsulación-deshidratación utilizando dos estados de deshidratación del material (25 y 35 $\%$ sobre peso fresco). No se encontraron diferencias significativas entre el control sin

crioconservar y los embriones deshidratados hasta el $35 \%$, pero sí hubo polimorfismo al 25 $\%$ de deshidratación. Zhang y col. (2015) utilizaron la vitrificación-droplet en ápices de petunia y no encontraron diferencias genéticas tras la crioconservación mediante marcadores SSR.

\subsubsection{Otros marcadores}

Existen variaciones de los RAPDs como por ejemplo los DAF y RAF. Los marcadores DAF (DNA Amplification Fingerprinting; Caetano-Anollés et al. 1991) emplean cebadores arbitrarios de 5 nucleótidos de longitud. Esto incrementa la probabilidad de hibridación con el ADN molde respecto a los RAPD y, por lo tanto, resulta en un perfil más complejo de bandas. La visualización se lleva a cabo por medio de geles de poliacrilamida teñidos con plata. Los marcadores RAF (Randomly Amplified DNA Fingerprinting) son una modificación del protocolo de los DAF, publicada por Waldron y col. el año 2002. Es más sensible ya que marca los productos de amplificación con radiactividad o fluorescencia y luego se separan y detectan en geles de secuenciación de poliacrilamida. Kaity y col. (2009) utilizaron marcadores RAF para evaluar la estabilidad genética de plantas de papaya procedentes de ápices crioconservados por vitrificación-droplet, y encontraron pequeñas modificaciones en el ADN en plantas que habían sido llevadas a campo.

Además de los marcadores empleados para detectar polimorfismos en la secuencia de $\mathrm{ADN}$, se han desarrollado marcadores capaces de evaluar variaciones epigenéticas, concretamente variaciones en el estado de metilación del ADN. Las variaciones epigenéticas son cambios que no implican a la secuencia de $\mathrm{ADN}$ primaria y que no siguen las leyes mendelianas de la herencia (Harding, 2004), pero que afectan a la expresión génica. Los marcadores MSAP (Methylation Sensitive Amplified Polymorphism) son una modificación de los AFLP, donde se reemplaza la enzima de corte frecuente MseI por los isoesquizómeros HpaII y MspI, sensibles a la metilación de la citosina, con distinto comportamiento en el sitio de reconocimiento 5'-CCGG- 3'. Hao y col. (2002) analizaron mediante AFLP y MSAP, ápices de fresa crioconservados por encapsulación-deshidratación. De las 16 combinaciones 
de cebadores utilizados (AFLP) sólo con una se detectó variabilidad en las muestras crioconservadas. Con MSAP encontraron que la crioconservación inducía un cambio significativo en el estado de metilación del ADN. Comparando el estado de metilación mediante MSAP de ápices de patata crioconservados por vitrificación-droplet y de material conservado en cultivo in vitro, en ambos casos durante 7 años, se observó que el material crioconservado presentó una hipometilación del 0,6 \% y el material in vitro presentó una hipermetilación del 0,2 \% (Kaczmarczykea et al. 2010). Por lo tanto, la crioconservación a largo plazo y en el mantenimiento in vitro parecen inducir cambios limitados del estado de metilación del ADN.

\subsection{Daño oxidativo en el cultivo in vitro y la crioconservación}

Radical libre es aquella especie química, átomo o molécula que posee uno o más electrones desapareados en su orbital externo. El radical tiende a recuperar la estabilidad cediendo o captando electrones, volviéndose muy reactivo. La molécula a la cual se le sustraen o donan esos electrones se convierte a su vez en un radical, lo que provoca una reacción en cadena en la formación de radicales (Benson 1990). En las plantas, la formación de radicales es algo natural, producto de la cadena de transporte de electrones en cloroplastos y mitocondrias, la cual puede sufrir alteraciones en su funcionamiento a consecuencia de condiciones ambientales adversas, mediante la activación de diferentes oxidasas y peroxidasas que producen radicales en respuesta a ciertos cambios ambientales (Apel y Hirt 2004). También participan en el mecanismo de defensa de las plantas ante el ataque de patógenos, tanto en la neutralización del patógeno o creando una barrera física para evitar su avance, como en la señalización para activar respuestas de defensa (Torres 2010). Intervienen en procesos de crecimiento y desarrollo vegetal, como respuesta a estímulos ambientales y en la muerte celular programada (Apel y Hirt 2004; Torres 2010). En general, la formación de cierta tasa de radicales libres es un proceso normal e inevitable, ya que son producto de infinidad de reacciones químicas imprescindibles para la vida celular de todos los organismos aeróbicos que utilicen metabolismos energéticos basados en reacciones de oxidación /reducción.

Existe una gran cantidad de radicales libres, tanto derivados del oxígeno como del nitrógeno y debido a su gran reactividad, se caracterizan por tener una vida media del orden de milisegundos. Los radicales libres se pueden formar de maneras diferentes, por la adición de un electrón a una molécula neutra, la pérdida de un electrón de una molécula neutra, o 
escisión de un enlace (de dos electrones) entre los átomos de tal manera que cada uno recibe un electrón (Benson y Bremner 2004). Las especies reactivas del oxígeno (Reactive Oxygen Species ROS) comprenden tanto radicales libres (como por ejemplo el $\mathrm{O}_{2}{ }^{*}$, radical superóxido y $\mathrm{OH} \bullet$, radical hidroxilo) como no radicales o moleculares (como el $\mathrm{H}_{2} \mathrm{O}_{2}$, peróxido de hidrógeno, el $\mathrm{O}_{3}$, ozono, ${ }^{1} \mathrm{O}_{2}$, oxígeno singlete, entre otros; Gill y Tuteja 2010; Halliwell y Gutteridge 2000).

ROS y NO son moléculas señal que intervienen en numerosos procesos celulares (Kovalchuk 2011), como son los procesos de muerte celular programada (Programmed Cell Death PCD) y la respuesta frente diversas situaciones de estrés (Mittler 2002). Las células vegetales producen ROS en bajas concentraciones, pero diversos estreses pueden trastocar la homeostasis celular y producir un aumento súbito de ROS. NO es una molécula señal en diversos procesos de las plantas, por ejemplo, cierre de las células oclusivas, resistencia a enfermedades y estreses abióticos, y también procesos de desarrollo (Delledonne 2005; Neill et al. 2008; Kasprowicz et al. 2009). NO es inducido por estreses abióticos y bióticos y está implicado en la activación de la muerte celular, cambios en la síntesis de hormonas y expresión de genes en Arabidopsis thaliana (Ahlors et al. 2008). En células animales, NO también actúa como antioxidante previniendo la muerte celular (Chung et al. 2001).

El rápido incremento en los niveles de ROS puede surgir ante la presencia de estrés, con la activación del complejo enzimático NADPH oxidasa asociado a la membrana plasmática transfiriendo electrones desde el interior de la membrana al oxígeno molecular en el exterior, produciendo el radical superóxido. $\mathrm{El} \mathrm{O}_{2}{ }^{*-}$ pasaría (mediante la acción de la superóxido dismutasa, SOD) a peróxido de hidrógeno generando la posterior aparición transitoria de otras especies de oxígeno (Benson y Bremner, 2004).

En el caso del oxígeno, en su estado diatómico $\left(\mathrm{O}_{2}\right)$ tiene dos electrones no apareados, es un radical, pero en su estado normal se encuentra como triplete $\left({ }^{3} \mathrm{O}_{2}\right)$ y aunque pudiera actuar como agente oxidante altamente reactivo, sólo acepta un electrón a la vez. Si a un singlete $\mathrm{O}_{2}$ $\left({ }^{1} \mathrm{O}_{2}\right)$ se le adiciona un electrón se forma el radical superóxido $\mathrm{O}_{2}{ }^{\cdot-}$ (Fig. 1.1), que es reactivo en entorno hidrófobo, tal como es el interior de la membrana, y es capaz de generar en la célula vegetal en el inicio del "estallido" oxidativo de las células.

Cuando a $\mathrm{O}_{2}$ se añaden dos electrones junto con dos protones resulta el peróxido de hidrógeno $\mathrm{H}_{2} \mathrm{O}_{2}$ (Fig. 1.1). El peróxido de hidrógeno se produce en diversos sistemas de la planta, directamente durante la hidroxilación de algunas enzimas o en su gran mayoría por la 
acción de las enzimas superóxido dismutasas (SOD; Benson y Bremner, 2004). Es la forma menos reactiva de las ROS. Su importancia recae en el hecho de que participa en numerosas reacciones que dan lugar a la generación de radicales libres (reacciones de Fenton y HaberWeiss). Atraviesa con suma facilidad las membranas biológicas, con lo que puede dar lugar a reacciones de oxidación en puntos de la célula más alejados de su lugar de producción.

$\mathrm{El} \mathrm{OH \bullet} \mathrm{es} \mathrm{la} \mathrm{especie} \mathrm{más} \mathrm{oxidante} \mathrm{conocida} \mathrm{ya} \mathrm{que} \mathrm{reacciona} \mathrm{inmediatamente} \mathrm{con} \mathrm{las}$ moléculas más cercanas. La fuente más común del radical hidroxilo son las reacciones de Fenton y la de Haber-Weiss (Dat et al. 2000) donde se produce la oxidación del peróxido de hidrógeno catalizada por la presencia de metales como el hierro (Fe ${ }^{2+}$; (Fig. 1.1). Puede convertir los ácidos grasos de la membrana, como el linolénico, linoléico y araquidónico, en peróxidos lipídicos, con el consiguiente daño a la correcta funcionalidad de la membrana que esto supone. También puede reaccionar con el ADN, provocando daño en las bases y roturas en la cadena, y con proteínas (Benson y Bremner, 2004).

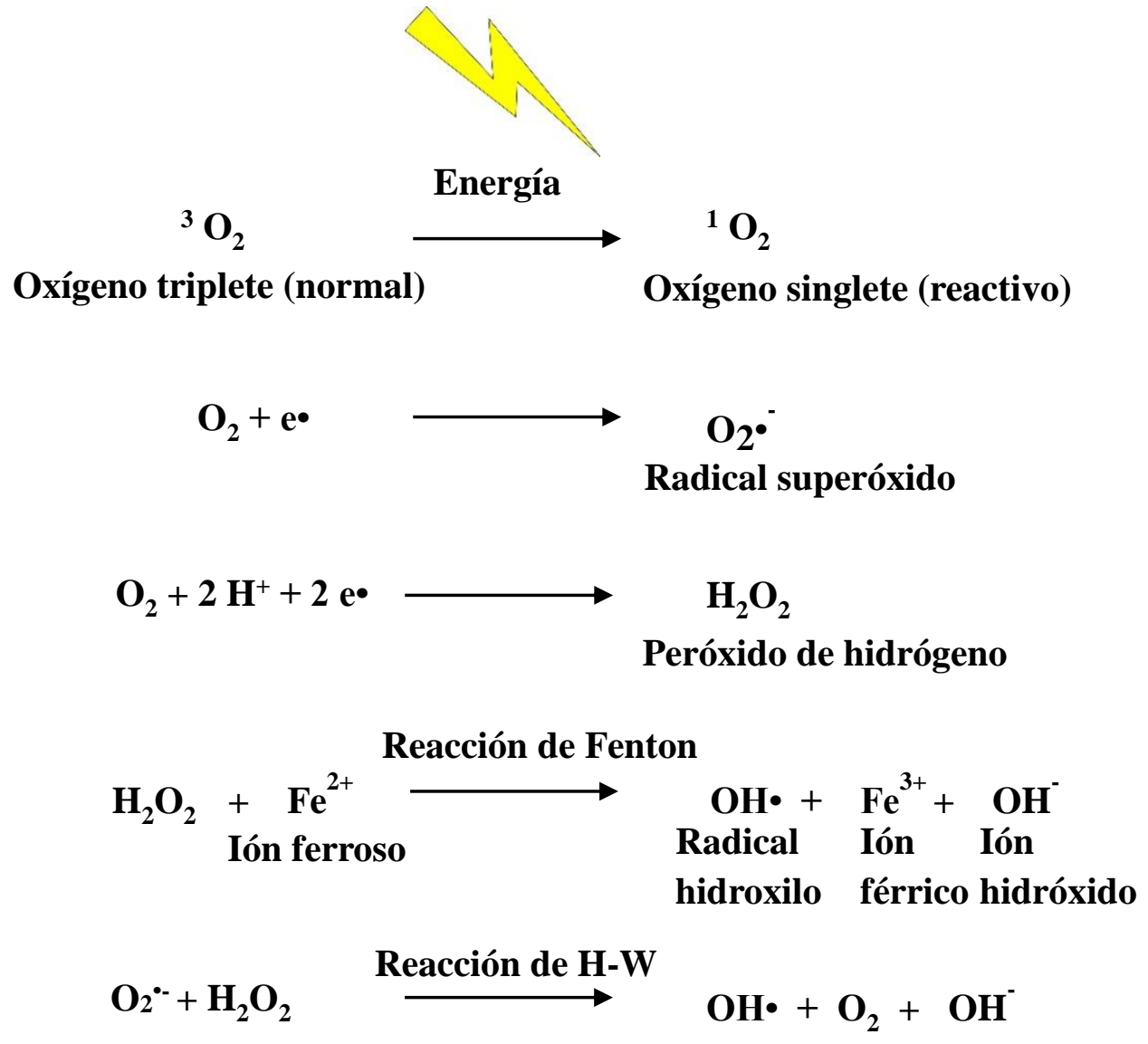

Figura 1.1. Adición de energía, electrones y protones al oxígeno, reacción de Fenton y reacción Haber-Weiss (H-W) en la formación de radicales libres. Fuente: Dat et al. 2000. 
En las plantas existen diversos sistemas antioxidantes para protegerse del ataque de los radicales libres. El antioxidante al reaccionar con el radical libre le cede un electrón, oxidándose a su vez y transformándose en un radical libre débil con escasos o nulos efectos tóxicos (Criado y Moya 2009). Cuando la protección antioxidante se satura, como resultado de estrés, enfermedades patológicas, el envejecimiento o por daño físico, comienza una producción descontrolada de especies reactivas del oxígeno (Benson 2000).

Los mecanismos antioxidantes que protegen a las plantas contra los daños de estrés oxidativo pueden ser de origen enzimático (como superóxido dismutasa, SOD; catalasa, CAT; peroxidasas, POD y glutatión reductasa, GR); y no enzimático (ácido ascórbico, AA; glutatión, GSH; compuestos fenólicos, alcaloides, aminoácidos no proteicos y $\alpha$-tocoferoles; Gil y Tujeda 2010).

Los antioxidantes enzimáticos previenen la formación de nuevas especies de radicales libres. Actúan detoxificando los radicales libres (o especies que pueden generarlos) convirtiéndolos en moléculas menos dañinas, o impidiendo su formación.

La SOD cataliza la conversión del anión superóxido, originando peróxido de hidrógeno y oxígeno. Existen distintas formas de SOD ubicadas en diferentes compartimentos celulares, y dependiendo de distintos cofactores metálicos: $\mathrm{Zn} / \mathrm{Cu}-\mathrm{SOD}$ en citosol y cloroplastos, $\mathrm{Mn}$ SOD en mitocondria y peroxisoma, y Fe-SOC en cloroplastos. La CAT y las POD catalizan la descomposición del peróxido de hidrógeno en agua, localizándose a nivel de los peroxisomas. La GR se localiza predominantemente en los cloroplastos, y pequeñas cantidades han sido encontradas en la mitocondria y citosol. Se encarga de mantener la adecuada proporción GSH/GSSG. Cataliza la reducción del glutatión oxidado (GSSG) a glutatión reducido (GSH), el cual será utilizado por la glutatión peroxidasa para la reducción del peróxido de hidrógeno (Gill y Tudela 2010).

Los antioxidantes no enzimáticos intervienen cuando hay superproducción de radicales libres y los sistemas enzimáticos están sobrepasados, previniendo así las reacciones en cadena. También existe un sistema de reparación de biomoléculas dañadas por los radicales libres como las enzimas reparadoras de DNA (metionina sulfóxido reductasa y la fosfolipasa $\mathrm{A}_{2}$ ) que corta los fosfolípidos oxidados de la membrana (Demple y Halbrook 1983; Sevanian y Kim 1985; Dizdaroglu 1993). 
La vitamina $\mathrm{C}$ o ácido ascórbico (AA) es uno de los más abundantes y es considerado el más poderoso entre los antioxidantes naturales (Davey et al. 2004). Es soluble en agua y se encuentra en concentraciones elevadas en muchos tejidos. Su capacidad para donar electrones en un amplio rango de reacciones enzimáticas y no enzimáticas hace del ácido ascórbico el principal destructor de compuestos radicales en fase acuosa, tales como el radical superóxido y el radical hidroxilo. El ascorbato protege macromoléculas del daño oxidativo, y está presente en cloroplastos, citosol, vacuolas y en componentes extracelulares de la célula. También se produce en la pared celular donde es la primera línea de defensa contra el ozono y la radiación ultravioleta. Puede eliminar directamente al peróxido de hidrógeno antes de que se produzca la peroxidación lipídica, transformándolo en agua por la vía ascorbato peroxidasa. También puede regenerar tocoferol desde radicales tocoferoxil, proporcionando protección en la membrana (Uchendu et al. 2010). Sus características estructurales le permiten reaccionar con las ROSs oxidándose a dihidroascorbato (DHA) que se recicla a ácido ascórbico por el enzima dihidroascorbato reductasa (Smirnoff 2000).

El glutatión es un tripéptido constituido por tres aminoácidos: ácido glutámico, cisteína y glicina. Su estructura le confiere ciertas características que le otorgan una funcionalidad amplia e importante en la célula. Realiza muchas funciones que van desde la eliminación de especies reactivas de oxígeno, a la detoxificación de metales pesados (Davey et al. 2004). Su biosíntesis tiene lugar por la acción sucesiva de las enzimas Y-glutamilcisteína sintetasa y glutatión sintetasa en dos reacciones dependientes de ATP (Rennenberg, 1982). Dentro de las células, existe glutatión en su forma reducida (GSH) en un $90 \%$ y oxidada (GSSG) en un 10 $\%$. Un aumento de la relación GSSG/GSH se considera indicativo de estrés oxidativo. El glutatión reducido se oxida dando estabilidad a un radical libre, y su vez se convierte a sí mismo en inestable. En este estado el GSH reacciona fácilmente con otro GSH inestable para formar una molécula de GSSG estable. Posteriormente se convierte en GSH por el enzima glutatión reductasa. El glutatión se puede unir directamente a muchos xenobióticos inorgánicos y orgánicos (sustancias químicas extrañas) y compuestos cancerígenos, como los metales pesados de mercurio y arsénico. Además, está involucrado en muchos mecanismos metabólicos y bioquímicos como la síntesis y reparación del ADN, en la activación de enzimas y el transporte de aminoácidos a través de las membranas celulares.

Dentro de la vitamina E se incluye una familia de compuestos fenólicos llamados tocoferoles y tocotrienoles. Son altamente lipofílicos, de modo que tienden a concentrarse en las membranas celulares. El $\alpha$-tocoferol es el componente más abundante y previene la 
peroxidación de membranas por la estabilización de los radicales peroxilos. Al reaccionar con radicales, forma el radical tocoferoxil que es poco reactivo como para reaccionar con ácidos grasos poliinsaturados, actuando en la reacción de peroxidación lipídica como terminador de cadena (Uchendu et al. 2010). El radical de la vitamina E producido es estable porque el electrón desapareado del átomo de oxígeno puede ser deslocalizado dentro de la estructura de su anillo aromático (Londoñon, 2011).

Cuando se presenta un desequilibrio entre la producción de ROSs y la defensa antioxidante presente en los tejidos vegetales se genera el daño oxidativo. Consiste en una variedad de cambios fisiológicos y bioquímicos, que pueden llevar al deterioro de proteínas, carbohidratos, lípidos, ADN e incluso a la muerte celular. Entre los efectos secundarios de las reacciones de oxidación están las reacciones con el $\mathrm{ADN}$, donde los radicales hidroxilos oxidan azúcares, purinas y pirimidinas, lo que se denomina "daño oxidativo del ADN" (Benson y Bremner, 2004).

Cuando los radicales atacan la fracción lipídica de la membrana celular se produce la peroxidación lipídica, alterando el equilibrio entre solutos intra- y extracelulares, que puede llevar a la muerte celular (Kaczmarczyk et al. 2012). Los ácidos grasos poliinsaturados se transforman en radicales de lípidos, de conformación inestables y que a su vez se descomponen en productos secundarios tóxicos. Algunos de estos productos secundarios son el etileno y etanol (relativamente inocuos) y otros pueden ser aldehídos como el malondialdehído (MDA) o hidroxialquenales como el hidroxi-2-nonenal (HNE) que son citotóxicos, alteran la función celular y pueden ser mutagénicos (Dumet y Benson, 2000; Esterbauer et al. 1988). El MDA reacciona con las bases del ADN, especialmente guanina, provocando lesiones mutagénicas y el HNE inhibe el crecimiento celular y es genotóxico (Dizdaroglu, 1992; Cadet et al. 1999).

Para el estudio del nivel de oxidación celular se han desarrollado diversas técnicas y marcadores. Una medición directa de agentes oxidativos es difícil debido a que el tiempo de vida media es muy corto. Sin embargo, mediante la espectroscopía de resonancia paramagnética electrónica (EPR, Electron Paramagnetic Resonance Spectroscopy) se pueden detectar directamente los radicales libres, aunque los resultados son de difícil interpretación, ya que están influenciados por el contenido de agua y el estado fisiológico del tejido. Es una técnica cara y necesita especialistas en la instrumentalización y la interpretación de datos. 
Puede realizarse una detección indirecta a través de cromatografía de gases. Es un método no destructivo ni invasivo, donde al explanto se le adicionan concentraciones muy bajas de DMSO y se colocan en recipientes herméticos. El DMSO penetra en las células y descompone los radicales hidroxilo formando un radical metilo, que evoluciona a metano (volátil), o "gas marcador". Se extrae el aire del recipiente y se inyecta al cromatógrafo. Los niveles de formación de metano se correlacionan con el estrés, y se puede utilizar para monitorizar los diferentes pasos de un protocolo de crioconservación. También se pueden utilizar otros gases marcadores como el etileno y productos volátiles de la peroxidación lipídica como el etano y el pentano (Dumet y Benson 2000).

Los productos aldehídos de la peroxidación lipídica también se utilizan como marcadores del daño oxidativo. En este caso se trata de técnicas destructivas, ya que los compuestos deben ser extraídos de los tejidos. La técnica TBA o ensayo del ácido tiobarbitúrico, se basa en la reacción de éste con aldehídos formando sustancias reactivas del ácido tiobarbitútico (TBARS), que son cromóforos que pueden ser detectados a través de técnicas colorimétricas o fluorimétricas (Benson 2000; Davey et al. 2005) como la cromatografía líquida de alta eficacia (HPLC, High Performance Liquid Chromatography, HPLC) de fase inversa. En el caso del MDA, una molécula reacciona con dos moléculas de TBA formando el aducto $\operatorname{MDA}(\mathrm{TBA})_{2}$ que produce un pigmento de color rojo (Estepa et al. 2001). El nivel de coloración se atribuye a la formación de productos secundarios de la oxidación.

A través del Microscopio Láser Confocal Espectral (CLMS, Confocal Laser Scanning Microscopy) se pueden realizar mediciones in vivo de parámetro de interés bioquímico, como la acumulación de radicales libres, utilizando sondas fluorescentes específicas. Esta técnica permite la visualización celular y de estructuras subcelulares en secciones ópticas y obtener vistas tridimensionales de la distribución de la fluorescencia en el tejido (Sandalio et al. 2008). La sonda diacetato 2 ,7`- diclorofluoresceína (DCF-DA) se utiliza como marcador intracelular del $\mathrm{H}_{2} \mathrm{O}_{2}$ (Rodríguez-Serrano et al. 2006); el dihidroetidio (DHE) es utilizado como marcador para el $\mathrm{O}_{2}{ }^{-}$(Fink et al. 2004) y el diacetato 4,5-diaminofluorescina (DAF2DA), para detectar la presencia de NO (Corpas et al. 2004; Kojima et al. 1998).

Las anteriores técnicas pueden combinarse con el estudio del contenido de antioxidantes de los tejidos de las plantas crioconservadas (Benson 1990). La actividad antioxidante no puede medirse de forma directa, pero puede medirse la capacidad antioxidante presente en un tejido o muestra. El ensayo ABTS o del ácido 2-2'-azino-bis -(3-etilbenzotiazol-6- sulfónico) es un 
método espectroscópico, donde el radical formado por la reacción con persulfato potásico produce el cromóforo $\mathrm{ABTS}^{+}(\lambda=734 \mathrm{~nm})$. Los antioxidantes presentes en los tejidos lo vuelven a reducir a ABTS, con la consecuente disminución en la absorbancia. Los resultados se expresan como equivalentes en Trolox, análogo de la vitamina E (Johnstone et al. 2006).

Tanto en el cultivo de tejidos como los pasos de los protocolos de crioconservación se genera estrés oxidativo a los explantos, lo cual pueden conllevar a alteraciones en el material conservado, sobre todo a nivel de las membranas celulares (Dumet y Benson 2000).

La manipulación de las condiciones ambientales durante el cultivo de tejidos causa cambios en el metabolismo, fisiología y desarrollo de los explantos, lo que puede predisponer una mayor formación de radicales libres. Se ha asociado este estrés con la recalcitrancia en el cultivo de tejidos (Benson 2000b) que es la incapacidad de respuesta de los explantos a las técnicas desarrolladas e incluso a la pérdida de la capacidad totipotencial de sus células. También el traspaso de los cultivos a condiciones ex vitro supone un estrés a las plantas y provoca la formación de ROSs (Bat'ková et al. 2008). Se ha asociado la oxidación u oscurecimiento de tejidos a la acción de radicales libres, y a la oxidación de compuestos fenólicos catalizada por la enzima polifenol oxidasa (PPO) para producir quinonas, las cuales son especies químicas muy reactivas y propensas a reaccionar, generando daño e incluso la muerte celular (Bray 2002).

Durante la crioconservación se pueden producir daños o criolesiones, que son atribuidas tanto a daños físicos, como los que pueden ocurrir durante la desecación osmótica, o a daños provocados a nivel bioquímico. Actualmente hay considerable evidencia de que el estrés provocado durante la crioconservación promueve la producción de radicales libres (Benson 1990; Benson y Bremner 2004; Whitaker et al. 2010), en diversos pasos de los protocolos: excisión de los ápices, durante la deshidratación osmótica o la desecación, tras los tratamientos con crioprotectores y en los cambios de temperatura en el enfriamiento y calentamiento de los explantos (Benson y Bremner 2004; Roach et al. 2008). Las lesiones por congelación promueven cambios subletales como desacoplamientos metabólicos, que pueden conducir a la producción de radicales libres (Benson y Bremner, 2004).

Se han desarrollado procedimientos para disminuir la generación de estrés, como por ejemplo la aclimatación al frío como un tratamiento previo a la crioconservación, siendo un factor importante a considerar, ya que permite a las células llevar a cabo cambios metabólicos que mejorarán su capacidad para sobrevivir a la exposición a bajas temperaturas y otros 
estreses aplicados. Neven y col. (1992) encontraron una acumulación de proteínas especiales (proteínas de choque térmico) durante la aclimatación al frío, que posteriormente se unían a proteínas desnaturalizadas durante el proceso de desecación o tras el enfriamiento y que permitían reanudar la actividad fisiológica normal de los explantos. Baek y Skinner (2003) observaron que durante la aclimatación al frío existe un aumento en la expresión de genes específicos que codifican enzimas antioxidantes como la SOD y la catalasa. Un gran número de autores han incorporado este procedimiento al protocolo de crioconservación por sus beneficios en la recuperación de los explantos crioconservados (Senula et al. 2007; Martin et al. 2015; Uchenduet et al. 2010; Chang y Reed 1999; Gupta y Reed 2006; Leunufna y Keller 2005).

Uchendu y col. (2010) estudiaron el efecto del uso de tocoferol y ác. ascórbico en diferentes etapas del protocolo de vitrificación. Determinaron que con la vitamina E la formación de MDA en las células disminuía respecto al control sin antioxidante, y que la vitamina $\mathrm{C}$ mejoraba la recuperación de los ápices en todas las etapas en las que fue utilizada. Estos autores concluyeron que era recomendable la utilización de estas sustancias antioxidantes, especialmente en los medios de pretratamiento, en la solución de carga y en la solución de lavado. Wang y Deng (2004) utilizaron el GHS (forma reducida del glutatión) en las etapas de precultivo y en el medio de recuperación para mejorar la supervivencia de ápices de cítricos tras la crioconservación por vitrificación.

También se ha observado que, si se reduce temporalmente la exposición a la luz de las muestras crioconservadas inmediatamente después de la recuperación, manteniéndolas en oscuridad por 24 a 48 h se aumenta la supervivencia de los explantos debido a la eliminación del estrés foto-oxidativo (Senula et al. 2007; González-Arnao y Engelmann 2006).

\subsection{Especie objeto de estudio Mentha $\times$ piperita $\mathrm{L}$.}

\subsubsection{Taxonomía y morfología}

El género Mentha pertenece a la familia Lamiaceae o Labiatae, dentro de la subclase Asteridae. Son plantas perennes, de aspecto herbáceo, de crecimiento rápido, aromáticas y cuya parte aérea es generalmente caduca con tallos subterráneos rizomatosos (Morales, 2007). Las hojas son de tamaño y forma muy variables, desde linear-lanceoladas hasta anchamente lanceoladas u ovales, frecuentemente dentadas, pelosas. Posee inflorescencias formadas por 
cimas cortas y opuestas que crecen en verticilastros separados y que dejan a la vista el tallo florífero, en espigas más o menos densas o en cabezuelas. Sus brácteas son similares a las hojas; bractéolas lineares o anchas y digitadas. Las flores son generalmente pediceladas (Morales, 2007), de gineceo súpero y dos carpelos fusionados. En su epidermis poseen abundantes tricomas glandulares y no glandulares, simples y ramificados, característica común dentro de la familia Lamiaceae (Cantino,1990).

Mentha $\times$ piperita es un híbrido estéril entre Mentha aquatica L. y Mentha spicata L. (Arvy y Gallouin, 2006), cuyo nombre procede del latín "piper" que significa pimienta, haciendo referencia a su sabor picante, y es comúnmente llamada menta piperita (en inglés peppermint) o menta negra (Ladio, 2005). Sus hojas son oblongas ovaladas, de color verde oscuro con venas violetas (Fig. 1). Se encuentra en forma silvestre en casi todo el centro y sur de Europa, y en África del Norte (Sánchez, 1996). Las hojas contienen entre 1,2- 3,9 \% (v/p) de aceite esencial (rendimiento 0,38 \% a partir de hojas frescas) (Kaul et al. 2001) y los principales componentes volátiles identificados en su aceite son: mentol (33-60 \%), mentona (15-32\%), isomentona (2-8 \%), 1,8-cineol (eucaliptol; 5-13\%), acetato de metilo (2-11\%), mentofurano (1-10\%), limoneno (1-7 \%), $\beta$-mirceno $(0,1-1,7 \%), \beta$-cariofileno $(2-4 \%)$, pulegona (0,5-1,6\%) y carvona (1\%) (McKay y Blumberg, 2006; Bakalli et al. 2008). Sus principales componentes, el mentol y la mentona (Gul, 1994; Tucker 2012), ambos monoterpenos, junto al ácido rosmarínico y la carvona poseen propiedades antioxidantes, con una función ecológica de protección ante el estrés biótico y abiótico (Gershenzon y Croteau, 1991; Padmini et al. 2010).

Desde un punto de vista económico, la menta piperita es la especie productora más importante de monoterpenos (Gershenzon et al. 2000) y sumado a su riqueza en componentes aromáticos, ha hecho que sea una de las mentas más utilizada comercialmente (McKay y Blumberg, 2006). Según Mendes y col. (2013) no se han encontrado diferencias en la producción de aceites esenciales entre plantas ex vitro e in vitro. 


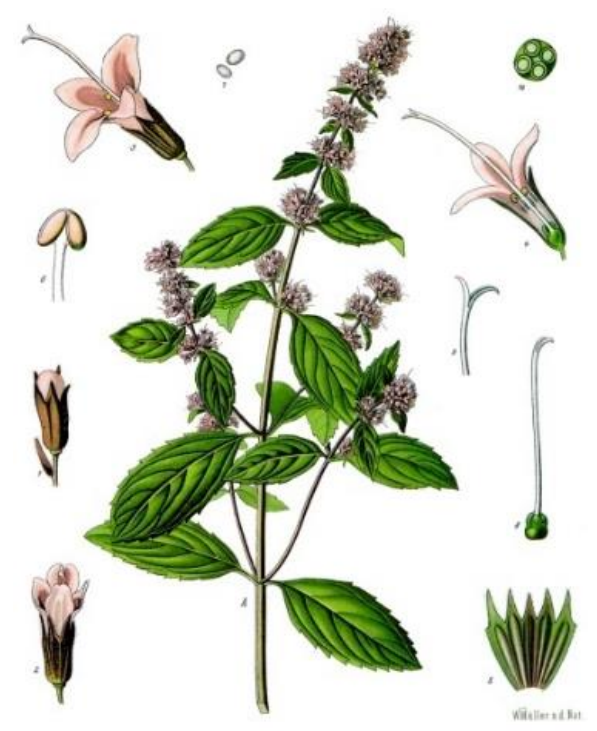

Figura 1. Mentha $\times$ piperita L. (Fuente: Franz Eugen Köhler, Wikipedia)

\subsubsection{Cultivo, importancia y usos}

Mentha $\times$ piperita prospera en climas húmedos $\mathrm{y}$ templados. Se cultiva en regiones templadas de Europa, Asia, Estados Unidos, India y países mediterráneos. Es sensible a la sequía (Metha et al. 2012).

Las mentas son especies aromáticas y medicinales, cuya principal importancia radica en la extracción de sus aceites esenciales sintetizados y almacenados en los tricomas glandulares de sus hojas (Lange y Croteau, 1999) y a la presencia de antioxidantes en sus tejidos (Gulluce et al. 2007). De sus diversos componentes, el mentol es el principal producto comercial. Es un alcohol secundario que tiene el efecto refrescante sobre las mucosas, además de ser antiséptico (Silva et al. 2006). Las mentas también tienen propiedades como antiespasmódico, digestivo, relajante intestinal, carminativo, antiinflamatorio, y analgésico. También se han encontrado propiedades antimicrobianas e insecticidas (Sivropoulou et al. 1995; Franzios et al. 1997; Miguel 2010). Por estas razones son muy utilizadas en la industria farmacéutica, cosmética y alimenticia. Sus usos son variados, como plantas ornamentales, sus hojas se utilizan de condimento de cocina, en la preparación de infusiones, y se encuentra en diversos productos como saborizante de caramelos, chicles, chocolates, tabaco, licores, dentífricos y como aromatizante ambiental. 


\subsubsection{Conservación in vitro y crioconservación de menta}

Dada la importancia de estas especies como recurso fitogenético, la conservación de la diversidad de la menta es crucial para mantener la mayor cantidad de genotipos disponibles y para asegurar el desarrollo de líneas mejoradas (Towill 2002b), para la obtención de una mayor calidad de aceites esenciales o para generar resistencias a plagas y enfermedades. En los diversos bancos de germoplasma se colectan y conservan las semillas de menta, donde se mantienen las accesiones con alta viabilidad durante períodos prolongados. Para esto se realizan los procedimientos adecuados en el manejo de las semillas que garanticen que éstas sean de la más alta calidad y alcancen la máxima longevidad a largo plazo y de manera eficiente y efectiva en costes. Las semillas de menta son tolerantes a la deshidratación (ortodoxas) y muestran una considerable longevidad almacenadas a bajas temperaturas (Towill 2002b); sin embargo, esta técnica es incompatible con la esterilidad de algunos híbridos, como es $M$. x piperita. Éstas se pueden mantener en invernaderos o en el campo, ya que la menta es muy prolífica y es fácil de multiplicar vegetativamente por estolones (Towill 2002b) y en cultivo in vitro.

Casi todas las especies e híbridos de menta pueden establecerse a través de sus ápices o meristemos, y su propagación in vitro es fácil si se utilizan sus yemas axilares o segmentos nodales (Ganthi et al. 2004; Kukreja 1996; Rech y Pires 1986). Existen diversos protocolos desarrollados para la micropropagación (Mehta et al. 2012; Rench y Pires 1986), el cultivo de protoplastos (Jullien et al. 1998) y para la regeneración tras la transformación genética (Caissard et al. 1986). La aplicación de técnicas de cultivo de tejidos de menta piperita se utiliza también en el área industrial, para su comercialización y producción (Zapata y Fernández, 2011), ya que la producción de aceites esenciales in vitro es la misma que aquellas propagadas vegetativamente (Holm et al. 1989). Un problema observado en el establecimiento in vitro de la menta es la proliferación de bacterias endófitas, para lo cual se pueden realizar tratamientos con antibióticos, aunque su eficiencia dependerá del explanto (Reed et al. 1995; Mbah y Wakil 2012). Normalmente un explanto de menta cultivado in vitro debe ser mensualmente subcultivado a medio fresco para evitar el agotamiento de los nutrientes. Para lograr conservar material por más tiempo sin traspasar a medio fresco, y así bajar los costes y el trabajo de mantenerlos, es necesario disminuir el crecimiento y desarrollo de los explantos, para lograr un almacenamiento a corto o medio plazo. La reducción de la temperatura de incubación ha mostrado ser muy efectiva en distanciar los ciclos de subcultivos ya que reduce la tasa de crecimiento de los vástagos. Así mismo, una reducción en la intensidad lumínica 
durante la incubación o incluso la oscuridad total, junto con un descenso de la temperatura, pueden disminuir las tasas de crecimiento (Islam et al. 2003) y pueden permanecer hasta un máximo de 30 meses a $4{ }^{\circ} \mathrm{C}$ sin ser subcultivadas (Towill 2002b).

Para la conservación de menta a largo plazo se han desarrollado diversos protocolos de crioconservación, y se han utilizado muchas de las técnicas descritas anteriormente (ver apartado 1.2.3).

Towill (1988) estudió el enfriamiento controlado en Mentha $\times$ piperita cv. Mitchan, $M . \mathrm{x}$ piperita (tipo), $M$. x piperita $\mathrm{cv}$. Citrata, $M$. spicata y $M$. arvensis demostrando que es una técnica factible para mantener colecciones base de menta. Posteriormente, Towill (1990) también describió una técnica de vitrificación para menta, señalando la importancia de la utilización de sustancias crioprotectoras y altas velocidades de enfriamiento para la supervivencia de los tejidos. En su estudio se utilizaron ápices de plantas de Mentha $\times$ piperita L. Esta técnica se propuso para obtener beneficios superiores al enfriamiento convencional, sin embargo, la exposición a altas concentraciones de crioprotectores requerida podía llegar a ser tóxica para los tejidos. La supervivencia obtenida en los explantos crioconservados en este caso fue entre $31 \%$ y $75 \%$. El autor sugirió que esta técnica simplificaba la crioconservación respecto del enfriamiento controlado, pero que era necesario realizar un mayor estudio y desarrollo.

Hirai y Sakai (1999) compararon las técnicas de encapsulación-deshidratación y la encapsulación-vitrificación en Mentha spicata L., incluyendo una aclimatación en frío de los vástagos. El mejor resultado se obtuvo en el procedimiento de encapsulación-vitrificación con un $87 \%$ de regeneración. Se determinó que el período óptimo de deshidratación de las cuentas fue de $3 \mathrm{~h}$ en PVS2 a $0{ }^{\circ} \mathrm{C}$. Finalmente se concluyó que el tratamiento de encapsulación-vitrificación producía tasas de regeneración de los meristemos mucho mayores que la encapsulación-desecación, en aquellos meristemos con o sin preaclimatación al frío.

Un año después, Sakai y col. (2000) describieron un protocolo simplificado y eficiente para la crioconservación de menta (Mentha spicata L.) a través de encapsulacióndeshidratación, el cual fue comparado con la técnica de encapsulación-vitrificación y la encapsulación-deshidratación tradicional. Los resultados de regeneración de los explantos fueron mucho mayores en la encapsulación-vitrificación llegando a casi un $90 \%$. Con el nuevo procedimiento se obtuvieron mejores resultados que con el protocolo convencional de encapsulación-desecación (61 \% y 51,3 \% de formación de vástagos, respectivamente). 
Además, se redujo el tiempo del proceso al eliminar la etapa de osmoprotección de las cuentas en sacarosa y al disminuir el tiempo de deshidratación de tres a dos horas.

Volk y Walters (2006) estudiaron los efectos de la solución PVS2 como tratamiento crioprotector previo a la crioconservación de segmentos nodales de Mentha $\times$ piperita L. cv. Mitcham. En este estudio se evidenció que la solución PVS2 posee la capacidad de retirar el agua celular y cambiar las características de congelación y fusión de las soluciones celulares. Sus componentes penetran en las células y así limitan el riesgo de formación y crecimiento de hielo. Se determinó que la exposición de los ápices a la solución PVS2 por 30 min era la óptima para obtener una mayor supervivencia.

Uchendu y Reed (2008) compararon tres de las técnicas de crioconservación utilizadas en menta: enfriamiento controlado, vitrificación y encapsulación-deshidratación. Utilizaron plántas micropropagadas de Mentha $\times$ piperita subsp. citrata, M. canadienses, M. australis y M. cunninghamii. Los resultados mostraron que la regeneración después del enfriamiento controlado era significativamente mayor (93\%) que en la encapsulación-deshidratación (71 $\%)$ y en la vitrificación (73\%).

Senula y col. (2007) publicaron un procedimiento de crioconservación por vitrificacióndroplet que simplificaba la manipulación de los procedimientos antes mencionados, aplicable a un gran número de genotipos en menta y con una alta regeneración de plantas. En el estudio se trabajó con tres especies: Mentha $\times$ piperita L., M. x villosa Huds. y M. spicata L. En el protocolo se recomienda incubar en PVS2 por 20-22 min a temperatura ambiente, ya que el procedimiento así es más fácil de realizar que a $0^{\circ} \mathrm{C}$. También se advierte de la importancia que tiene el estado fisiológico del material a crioconservar, ya que es clave en el éxito de la técnica. Se recomienda evaluar previamente la presencia de infecciones latentes en las plantas, como la presencia de bacterias endógenas que puedan afectar a su regeneración postcrioconservación de los explantos.

El año 2012 Yamamoto y col. utilizaron la técnica V-cryo-plate y obtuvieron porcentajes de regeneración del 73-100 \%. Destacaron la facilidad en la manipulación del material durante la crioconservación y concluyeron que esta técnica facilita el crioalmacenaje en los bancos de germoplasma. 


\subsection{Bibliografía}

Ahlors R, Brosche M, Kollist H, Kangasjarvi J (2008) Nitic oxide modulates ozoneinduced cell death, hormone biosynthesis and gene expression in Arabidopsis thaliana. Plant J. 58: 1-12

Ai P-F, Lu L-P, Song J-J (2012) Cryopreservation of in vitro-grown shoot-tips of Rabdosia rubescens by encapsulation-dehydration and evaluation of their genetic stability. Plant Cell Tiss Organ Cult 108:381-387

Apel K, Hirt H (2004) Reactive Oxygen Species: metabolism oxidative stress and signal transduction. Annu. Rev. Plant Biol 55:373-99

Aronen TS, Krajnakova J, Häggman HM, Ryynänen LA (1999) Genetic fidelity of cryopreserved embryogenic cultures of open-pollinated Abies cephalonica. Plant Science $142: 163-172$

Arvy MP, Gallouin F (2006) Especias, aromatizantes y condimentos. Ediciones MundiPrensa, Madrid pp 353-368

Ávalos A, Pérez-Urria E (2009) Metabolismo secundario de plantas. Reduca (Biología) Serie Fisiología Vegetal 2:119-145

Bacchetta G, Grillo O, Mattana E, Venora G (2008) Morpho-colorimetric characterization by image analysis to identify diaspores of wild plant species. Flora-Morphology Distribution Functional Ecology of Plants 203: 669-682

Baek KH, Skinner DZ (2003) Alteration of antioxidant enzyme gene expression during cold acclimation of near-isogenic wheat lines. Plant Science 165:1221-1227

Bakkali F, Averbeck S, Averbeck D, Idaomar M (2008) Biological effects of essential oilsA review. Food and Chemical Toxicology 46:446-475

Bat'ková P, Pospíšilová J, Synkova H (2008) Production of reactive oxygen species and development of antioxidative systems during in vitro growth and ex vitro transfer. Biologia Plantarum 52:413-422

Benson EE (1990) Free radical damage in stored plant germplasm. International Board for plant genetic resources (Roma) 
Benson EE (2000) Special symposium: in vitro plant recalcitrance do free radicals have a role in plant tissue culture recalcitrance?. In Vitro Cell Dev Biol-Plant 36:163-170

Benson EE (2008) Cryopreservation of phytodiversity: a critical appraisal of theory \& practice. Critical reviews in plant sciences 27:141-219

Benson EE, Bremner DH (2004) Oxidative stress in the frozen plant. En Fuller B, Lane N, Benson EE (eds.) Life in the Frozen State. CRC Press LLC Florida, pp. 205-242

Berjak P, Walker M, Mycock DJ, Wesley-Smith P, Pammenter NW (2000) Cryopreservation of recalcitrant zygotic embryos. Cryopreservation of tropical plant germplasm. En Engelmann F, Takagi H (eds.) Cryopreservation of Tropical Plant Germplasm - current research progress and applications. JIRCAS/IPGRI, Tsukuba (Japón)/Roma (Italia), pp 141-155

Bray EA (2002) Classification of genes differentially expressed during water-deficit stress in Arabidopsis thaliana: An analysis using microarray and differential expression data. Annals of botany 89:803-811

Burke MJ (1986) The glassy state and survival of anhydrous biological systems. En: Leopold AC (ed) Membranes Metabolism and Dry Organisms. Comstock Publishing Associates, Nueva York, pp 358-363

Cadet J, Delatour T, Douki T, Gasparutto D, Pouget JP, Ravanat JL, Sauvaigo S (1999) Hydroxyl radicals and DNA base damage. Mutation Research/Fundamental and Molecular Mechanisms of Mutagenesis 424:9-21

Caetano-Anollés G, Bassam BJ, Gresshoff PM (1991) DNA amplification fingerprinting using very short arbitrary oligonucleotide primers. Bio/Technology 9: 553-557

Caissard JC, Faure O, Jullian F, Colson M, Perrin A (1986) Direct regeneration in vitro and transient GUS expression in Mentha x piperita. Plant Cell Rep 16:67-70

Cantino PD (1990) The phylogenetic significance of stomata and trichomes in the Labiatae and Verbenaceae. Journal Arnold Arboretum 71: 323-370

Castillo NRF, Bassil NV, Wada S, Reed BM (2010) Genetic stability of cryopreserved shoot tips of Rubus germplasm. In Vitro Cell Dev Biol-Plant 46:246-256 
CBD (1992) Convenio sobre la diversidad biológica. Naciones Unidas http://www.cbd.int/convention/text/ Consulta: octubre 2015

Chang Y, Barker RE, Reed BM (1999). Cold acclimation improves recovery of cryopreserved grass (Zoysia and Lolium sp.). CryoLetters 21:107-116

Chang Y, Reed BM (1999) Extended cold acclimation and recovery medium alteration improve regrowth of Rubus shoot tips following cryopreservation. CryoLetters 20: 371-376

Chang Y, Reed BM (2000) Extended Alternating-Temperature Cold Acclimation and Culture Duration Improve Pear Shoot Cryopreservation. Cryobiology 40:311-322

Chen WH, Chen TM, Fu YM, Hsieh RM, Chen WS (1998) Studies on somaclonal variation in Phalaenopsis. Plant Cell Reports 18: 7-13

Chowdhury MKU, Vasil IK (1993) Molecular analysis of plants regenerated from embryogenic cultures of hybrid sugarcane cultivars (Saccharum spp.) Theoretical and Applied Genetics 86:181-188

Chu CC, Wang CC, Sun CS, Hsu C, Yin K C, Chu CY, Bi FY (1975) Establishment of an efficient medium for anther culture of rice through comparative experiments on the nitrogen sources. Sci Sinica 18:659-668

Chung HT, Pae HO, Choi BM, Billiar TR, Kim YM (2001) Nitric oxide as a bioregulator of apoptosis. Biochemical and Biophysical Research Communications 282:1075-1079

Condello E, Palombi MA, Tonelli MG, Damiano C, Caboni E (2009) Genetic stability of wild pear (Pyrus pyraster Burgsd) after cryopreservation by encapsulation dehydration. Agricultural and Food Science 18:136-143

Corpas FJ, Barroso JB, Carreras A, Quirós M, León AM. Romero-Puertas MC, Esteban FJ, Valderrama R, Palma JM, Sandalio LM, Gómez M, del Río LA (2004) Cellular and subcellular localization of endogenous nitric oxide in young and senescent pea plants. Plant Physiol 136:2722-2733

Criado C, Moya M (2009) Vitaminas y antioxidantes. Madrid: Sanidad y Ediciones, pp 234 
Crowe JH, Crowe LF, Chapman D (1984) Preservation of membranes in anhydrobiotic organisms: The role of trehalose. Science 233: 701-703

Cruz-Cruz CA, González-Arnao MT, Engelmann, F (2013) Biotechnology and conservation of plant biodiversity. Resources 2:73-95

Cyr DR, Lazaroff WR, Grimes SM, Quan G, Bethune TD, Dunstan DI, Roberts DR (1994) Cryopreservation of interior spruce (Picea glauca engelmanni complex) embryogenic cultures. Plant Cell Reports 13:574-577

Dat J, Vandenabeele S, Vranová E, Van Montagu M, Inzé D, Van Breusegem F (2000) Dual action of the active oxygen species during plant stress responses. Cellular and Molecular Life Sciences CMLS 57:779-795

Davey MW, Franck C, Keulemans J (2004) Distribution, developmental and stress responses of antioxidant metabolism in Malus. Plant Cell \& Environment 27:1309-1320

Davey MW, Stals E, Panis B, Keulemans J, Swennen RL (2005) High-throughput determination of malondialdehyde in plant tissues. Analytical biochemistry 347:201-207

Delledonne M (2005) NO news is good news for plants. Current Opinion in Plant Biology 8:390-396

Demple B, Halbrook J (1983) Inducible repair of oxidative DNA damage in Escherichia coli. Nature 304:466-468

DeVerno LL, Park IS, Bonga JM, Barrett JD, Simpson C (1999) Somaclonal variation in cryopreserved embryogenic clones of white spruce (Picea glauca (Moench) Voss.). Plant Cell Rep 18:948-953

Dizdaroglu M (1991) Chemical determination of free radical-induced damage to DNA. Free Radical Biology and Medicine 10:225-242

Dumet D, Benson EE (2000) The use of physical and biochemical studies to elucidate and reduce cryopreservation-induced damage in hydrated/desiccated plant germplasm. En Engelmann F, Takagi H (eds.) Cryopreservation of Tropical Plant Germplasm - current research progress and applications. JIRCAS/IPGRI, Tsukuba (Japón)/Roma (Italia), pp. 43-56 
Dussert S, Chabrillange N, Engelmann F, Anthony F, Hamon S (2000) Cryopreservation of coffee (Coffea arabica L.) seeds: toward a simplified protocol for routine use in coffee genebanks. En Engelmann F, Takagi H (eds.) Cryopreservation of Tropical Plant Germplasm - current research progress and applications. JIRCAS/IPGRI, Tsukuba (Japón)/Roma (Italia), pp 161-166

Engelmann F (1991) In vitro conservation of tropical plant germplasm - a review. Euphytica 57:227-243

Engelmann F (1997) In vitro conservation method. En: Ford-Lloyd BV, Newburry JH, Callow JA (eds.) Biotechnology and Plant Genetic Resources: Conservation and Use. Ed. CAB International, Wellingford, pp. 119-162

Engelmann F (2004) Plant cryopreservation: progress and prospects. Biodiversity. In Vitro Cell Dev Biol-Plant 40:427-433

Engelmann F (2011) Use of biotechnologies for the conservation of plant biodiversity. In Vitro Cell Dev Biol-Plant 47:5-16

Engelmann F (2014) Cryopreservation of Clonal Crops: a Review of Key Parameters. Acta Horticulturae 1039:31-39

Engelmann F, Arnao MT, Wu Y, Escobar R (2008) Development of encapsulation dehydration. En Reed BM (ed.) Plant cryopreservation: a practical guide. Ed. Springer Nueva York, pp. 59-75

Engelmann F, González-Arnao MT, Yongjie W, Roosevelt E (2008) Development of encapsulation dehydration. En: Reed BM (ed.) Plant Cryopreservation. Ed. Springer, Nueva York, pp. 59-75

Escobar RH, Debouck D, Roca W (2000) Development of cassava cryopreservation. En Engelmann F, Takagi H (eds.) Cryopreservation of Tropical Plant Germplasm - current research progress and applications. JIRCAS/IPGRI, Tsukuba (Japón)/Roma (Italia), pp 222226

Estepa V, Ródenas S, Martín MC (2001) Optimización de un método para la determinación de la peroxidación lipídica en suero humano. Anal Real Acad Farm 67:1-17 
Esterbauer H, Zollner H, Schaur RJ (1988) Hydroxyalkenals: cytotoxic products of lipid peroxidation. ISI Atlas Sci Biochem 1:311-317

Fabre J, Dereuddre J (1990) Encapsulation-dehydration: a new approach to cryopreservation of Solanum shoot tips. CryoLetters 11:413-426

Fahy GM, Macfarlane DR, Angell CA, MerymanhnT (1984) Vitrification as an approach to cryopreservation. Cryobiology 21:407-426

FAO (2011) Segundo Plan de Acción Mundial para los Recursos Fitogenéticos para la Alimentación y la Agricultura. Comisión de recursos genéticos para la alimentación y la agricultura de la Organización de las Naciones Unidas para la Alimentación y la Agricultura Roma Italia. http://www.fao.org/docrep/ Consulta: octubre 2015

Fernandes P, Rodriguez E, Pinto G, Roldán-Ruiz I, De Loose M, Santos C (2008) Cryopreservation of Quercus suber somatic embryos by encapsulation-dehydration and evaluation of genetic stability. Tree Physiology 28:1841-1850

Fink B, Laude K, McCann L, Doughan A, Harrison DG, Dikalov S (2004) Detection of intracellular superoxide formation in endothelial cells and intact tissues using dihydroethidium and an HPLC-based assay. Am J Physiol Cell Physiol 287:895-902

Franzios G, Mirotsou M, Hatziapostolou E, Kral J, Scouras Z, Marvragani-Tsipidou P (1997) Insecticidal and genotoxic activities of mint essential oils. Journal of Agricultural and Food Chemistry 45:2690-2694

Gamborg OL, Eveleigh DE (1968) Culture methods and detection of glucanases in suspension cultures of wheat and barley. Can J Biochem 46:417-421

Garbus I, Gómez M, Echenique V (2004) Herramientas Básicas de Ingeniería Genética. En Levitus G, Echenique V, Rubinstein C, Hopp E, Mroginski L (eds.) Biotecnología y Mejoramiento Vegetal II. Consejo Argentino para la Información y el Desarrollo de la Biotecnología, pp 47-69

García-Águila L, de Feria M, Acosta K (2007) Aspectos básicos de la conservación in vitro de germoplasma vegetal. Biotecnología Vegetal 7: 67-79 
Gaspar T, Kevers C, Penel C, Greppin H, Reid DM, Thorpe TA (1996) Review: plant hormones and plant growth regulators in plant tissue culture. In Vitro Cell Dev Biol Plant $32: 272-28$

Gershenzon J, Croteau R (1991) Terpenoids. En: Rosenthal GA, Berenbaum MR (eds.) Herbivores: Their Interactions with Secondary Plant Metabolites. Ed Academic Press, Nueva York, pp 165-219

Gershenzon J, McConkey ME y Croteau RB (2000) Regulation of Monoterpene Accumulation in Leaves of Peppermint. Plant Physiol 122:205-213

Gil SS, Tuteja N (2010) Review: Reactive oxygen species and antioxidant machinery in abiotic stress tolerance in crop plants. Plant Physiology and Biochemistry 48:909-930

González-Arnao MT, Engelmann F, Urra-Villavicencio C, Morenza M, Ríos A (2000) Cryopreservation of citrus apices using the encapsulation-dehydratation technique. En Engelmann F, Takagi H (eds.) Cryopreservation of Tropical Plant Germplasm - current research progress and applications. JIRCAS/IPGRI, Tsukuba (Japón)/Roma (Italia), pp 217221

Gonzalez-Arnao MT, Engelmann, F (2006) Cryopreservation of plant germplasm using the encapsulation-dehydration technique: review and case study on sugarcane. CryoLetters 27:155-168

González-Benito ME, Clavero-Ramírez I, López-Aranda J M (2004) Review. The use of cryopreservation for germplasm conservation of vegetatively propagated crops. Spanish Journal of Agricultural Research 2:341-351

Gul P (1994) Seasonal variation of oil and menthol content in Mentha arvensis Linn. Pakistan Journal of Forestry 44:16-20

Gulluce M, Sahin F, Sokmen M, Ozer H, Daferera D, Sokmen A, Polossiou M, Adiguzel A, Ozkan H (2007) Antimicrobial and antioxidant properties of the essential oils and methanol extract from Mentha longifolia L. ssp. longifolia. Journal of Agricultural and Food Chemistry 103:1449-1456 
Gupta M, Chyi YS, Romero-Severson J, Own JL (1994) Amplification of DNA markers from evolutionary diverse genomes using single primers of simple-sequence repeats. Theoretical Applied Genetics 89:998-1006

Gupta S, Reed BM (2006) Cryopreservation of shoot tips of blackberry and raspberry by encapsulation-dehydration and vitrification. CryoLetters 27:29-42

Halliwell B, Gutteridge JM (1986) Oxygen free radicals and iron in relation to biology and medicine: some problems and concepts. Archives of biochemistry and biophysics 246:501514

Hao YJ, Liu QL, Deng XX (2001) Effect of Cryopreservation on Apple Genetic Resources at Morphological Chromosomal and Molecular Levels. Cryobiology 43: 46-53

Hao YJ, Liu QL, Deng XX (2002) Analysis of ploidy and the patterns of amplified fragment length polymorphism and methylation sensitive amplified polymorphism in strawberry plants recovered from cryopreservation. CryoLetters 23:37-46

Harding K (1991) Molecular stability of the ribosomal RNA genes in Solanum tuberosum plants recovered from slow growth and cryopreservation. Euphytica 55: 141-146

Harding K (2004) Genetic integrity of cryopreserved plant cells: a review. CryoLetters $25: 3-22$

Helliot B, Madur D, Dirlewanger E, De Boucaud MT (2002) Evaluation of genetic stability in cryopreserved Prunus. Plant Cell Rep 38:493-500

Hirai D, Sakai A (1999) Cryopreservation of in vitro-grown axillary shoot-tip meristems of mint (Mentha spicata L.) by encapsulation-vitrification. Plant Cell Reports 19: 150-155

Hirai D, Sakai A (2000) Cryopreservation of in vitrogrown meristems of potato (Solanum tuberosum L.) by encapsulation-vitrification. En Engelmann F, Takagi H (eds.) Cryopreservation of Tropical Plant Germplasm - current research progress and applications. JIRCAS/IPGRI, Tsukuba (Japón)/Roma (Italia), pp 205-211

Holm Y, Hiltunen R, Jokinen K, Tormala T (1989) On the quality of the volatile oil in micropropagated peppermint. Flavour and fragrance journal 4:81-84 
Hongbao M (2005) Development application of polymerase chain reaction (PCR) J Am Sci $1: 1-15$

Inagaki M (2000). Use of stored pollen for wide crosses in wheat haploid production. En Engelmann F, Takagi H (eds.) Cryopreservation of Tropical Plant Germplasm - current research progress and applications. JIRCAS/IPGRI, Tsukuba (Japón)/Roma (Italia), pp 13035

Iriondo J M (2001) Conservación de germoplasma de especies raras y amenazadas (Revisión). Invest Agr: Prod Prot Veg 16:4-24

Islam T, Leunufna S, Dembele P, Keller J (2003) In vitro conservation of four mint (Mentha spp.). Plant Tissue Culture 13: 37-46

Jaligot E, Beulé T, Rival A (2002) Methylation-sensitive RFLPs: characterization of two oil palm markers showing somaclonal variation-associated polymorphism. Theoretical and Applied Genetics 104:1263-1269

Jaramillo S, Baena M (2000) Conservación ex situ de Recursos Fitogenéticos. Instituto Internacional de Recursos Fitogenéticos (IPGRI) Grupo Américas Cali (Colombia), pp 128

Johnston JW, Harding K, Benson EE (2007) Antioxidant status and genotypic tolerance of Ribes in vitro cultures to cryopreservation. Plant Science 172:524-534

Johnstone C, Day JG, Staines H, Benson EE (2006) The development of a 22'-azinobis-(3ethyle-benzothizoline-6-sulfonic acid) radical cation decolourisation assay for evaluating total antioxidant status in an alga used to monitor environmental impacts in urban aquatic habitats. Ecological Indicators 6:280-289

Jullien F, Diemer F, Colson M, Faure O (1998) An optimizing protocol for protoplast regeneration of three peppermint cultivars (Mentha x piperita). Plant Cell Tiss and Org Cult 54: $153-159$

Kaczmarczyk A, Houben A, Keller ERJ, Mette MF (2010) Influence of cryopreservation on the cytosine methylation state of potato genomic DNA. CryoLetters 31: 380-391

Kaczmarczyk A, Menon A, Al-Hanbali A, Funnekotter B, Bunn E, Phang PY, Mancera RL (2012) Current issues in plant cryopreservation. En Katkov II (ed) Tech Open Access Publisher, pp 417-438 
Kaity A, Ashmore SE, Drew RA (2009) Field performance evaluation and genetic integrity assessment of cryopreserved papaya clones. Plant cell Rep 28:1421-1430

Kaity A, Ashmore SE, Drew RA, Dulloo ME (2008) Assessment of genetic and epigenetic changes following cryopreservation in papaya. Plant cell Rep 27:1529-1539

Kameswara N (2004) Plant genetic resources: Advancing conservation and use through biotechnology on the development and application of in vitro techniques for the conservation and use of plant genetic resources. African Journal of Biotechnology Vol. 3: 136-145

Kasprowicz A, Szuba A, Volkmann D, Baluska F, Wojtaszek P (2009) Nitric oxide modulates dynamic actin cytoskeleton and vesicle trafficking in a cell type-specific manner in root apices. Journal of Experimental Botany 60, 1605-1617

Kaul PN, Bhattacharya AK, Singh K, Rao BRR, Mallavarapu GR, Ramsh S (2001) Chemical investigation of peppermint (Mentha $\times$ piperita L.) oil. J Essent Oil Bear Plants $4: 55-58$

Keller ERJ, Senula A, Leunufna S, Grübe M (2007) Slow growth storage and cryopreservation - tools to facilitate germplasm maintenance of vegetatively propagated crops in living plant collections. International Journal of Refrigeration 29:411-417

Keller ERJ, Senula A, Zanke Ch, Grübe M, Kaczmarczyka A (2010) Cryopreservation and In Vitro Culture - State of the Art as Conservation Strategy for Genebanks Leibniz Institute of Plant Genetics and Crop Plant Research (IPK). Acta Horticulturae 918:99-112

Kim HH, Yoon JW, Park YE, Cho EG, Sohn JK, Kim TS, Engelmann F (2006) Cryopreservation of potato cultivated varieties and wild species: critical factors in droplet vitrification. CryoLetters 27:223-234

Kojima H, Nakatsubo N, Kikuchi K, Kawaraha S, Kirino Y, Nagoshi H, Hirata Y, Nagano $\mathrm{T}$ (1998) Detection and imaging of nitric oxide with novel fluorescent indicators: Diaminofluoresceins. Anal Chem 70 2446-2453

Kovalchuk I (2011) Multiple roles of radicals in plants. En Gupta SD (ed.) Reactive Oxygen Species and Antioxidants in Higher Plants. Science Publishers, Enfield (NH), pp3144 
Kukreja AK (1996) Micro propagation and shoot regeneration from leaf and nodal ex plants of peppermint (Mentha x piperita L). J spices Arom plants 51:11-119

Kushnarenko SV, Romadanova NV, Reed BM (2009) Cold acclimation improves regrowth of cryopreserved apple shoot tips. CryoLetters 30:47-54

Ladio A (2005) Malezas exóticas comestibles y medicinales utilizadas en poblaciones del noroeste patagónico: aspectos etnobotánicos y ecológicos. Boletín Latino Americano y del Caribe de Plantas Medicinales y Aromáticas 4: 75-80

Lange M, Croteau R (1999) Genetic engineering of essential oil production in mint. Plant Biology 2:139-144

Larkin PJ, Scowcroft WR (1981) Somaclonal variation-a novel source of variability from cell cultures for plant improvement. Theoretical and Applied Genetics 60:197-214

Leunufna S, Keller ERJ (2005) Cryopreservation of yams using vitrification modified by including droplet method: effects of cold acclimation and sucrose. CryoLetters 26: 93-102

Londoñon J (2011) Antioxidants: biological relevance and methods to measure their activity. En: Garcés LF (ed) Development and transversality Lasallian Research and Science, pp 129-162

Mandal BB, Ahuja-Ghosh S, Srivastava PS (2008) Cryopreservation of Dioscorea rotundata Poir: a comparative study with two cryogenic procedures and assessment of true-totype of regenerants by RAPD analysis. CryoLetters. 29:399-408

Marco-Medina A, Casas JL (2013) RAPD and phytochemical analysis of Thymus moroderi plantlets after cryopreservation. CryoLetters 34:119-27

Martín C, González-Benito ME (2005) Survival and genetic stability of Dendranthema grandiflora Tzvelev shoot apices after cryopreservation by vitrifcation and encapsulationdehydration. Cryobiology 51: 281-289

Martín C, Cervera MT, González-Benito ME (2011) Genetic stability analysis of chrysanthemum (Chrysanthemum $x$ morifolium Ramat) after different stages of an encapsulation-dehydration cryopreservation protocol. J Plant Physiol 168:158-166 
Martín C, Senula A, González I, Acosta A, Keller ERJ, González-Benito ME (2013) Genetic identity of three mint accessions stored by different conservation procedures: field collection in vitro and cryopreservation. Genet Resour Crop Evol 60:243-249

Martín, C, Kremer C, González-Benito ME, González I (2015) Influence of the cryopreservation technique, recovery medium and genotype on genetic stability of mint cryopreserved shoot tips. Plant Cell Tiss Organ Cult 122:185-195

Martínez C (2004) Marcadores moleculares. En Herramientas Básicas de Ingeniería Genética. Levitus G, Echenique V, Rubinstein C, Hopp E, Mroginski L (eds.) Biotecnología y Mejoramiento Vegetal II. Instituto Nacional de Tecnología Agropecuaria (Argentina), pp $70-85$

Masuelli, R (1999) Uso de marcadores moleculares en el mejoramiento genético de especies hortícolas. Avances en Horticultura 4:54-66

Matsumoto T, Akihiro T, Maki S, Mochida K, Kitagawa M, Tanaka D, Yamamoto S, Niino T (2013) Genetic stability assessment of wasabi plants regenerated from long-term cryopreserved shoot tips using morphological biochemical and molecular analysis. CryoLetters 34:128-136

Matsumoto T, Sakai A (1995) An approach to enhance dehydratation tolerance of alginatecoated dried meristems cooled to $-196^{\circ} \mathrm{C}$. CryoLetters 16: 299-306

Matsumoto T, Yamamoto S, Fukui K, Rafique T, Engelmann F, Niino T, (2015) Cryopreservation of Persimmon shoot tips from dormant buds using the D cryo-plate technique. Hortic J 84:106-110

Maxted N, Kell SP, Ford-Lloyd BV (2008) Crop wild relative conservation and use: establishing the context. En: Maxted N, Ford-Lloyd BD, Kell SP, Iriondo JM, Dulloo ME, Turok J (eds.) Crop wild relative conservation and use, pp 3-30

Mbah EI, Wakil SM (2012) Elimination of bacteria from in vitro yam tissue cultures using antibiotics Journal of Plant Pathology (2012) 94 (1) 53-58

McKay DL y Blumberg JB (2006) A Review of the Bioactivity and Potential Health Benefits of Peppermint Tea (Mentha x piperita L.). Phytother Res 20:619-633 
Mehta J, Naruka R, Sain M, Dwivedi A, Sharma D, Mirza J (2012) An efficient protocol for clonal micropropagation of Mentha x piperita L. (Pipperment). Asian Journal of Plant Science and Research 2:518-523

Mendes MD, Figueiredo AC, Oliveira MM, Trindade H (2013) Essential oil production in shoot cultures versus field-grown plants of Thymus caespititius. Plant Cell Tiss Organ Cult $113: 341-351$

Miguel MG (2010) Antioxidant and anti-inflammatory activities of essential oils: A short review. Molecules 15:9252-9286

Mikuła A, Tomiczak K, Rybczyński, JJ (2011) Cryopreservation enhances embryogenic capacity of Gentiana cruciata (L.) suspension culture and maintains (epi) genetic uniformity of regenerants. Plant cell reports 30:565-574

Mittler R (2002) Oxidative stress, antioxidants and stress tolerance. Trends in Plant Science 7:405-410

Morales R (2007) Mentha L. En: Castroviejo S (ed.) Flora Ibérica. Plantas Vasculares de la Península Ibérica e Islas Baleares. Ed Real Jardín Botánico CSIC, Madrid pp 1-11

Murashige T, Skoog F (1962) A revised medium for rapid bioassays with tobacco tissue cultures. Physiologia Plantarum 15: 473-497

Neelakandan AK, Wang K (2012) Recent progress in the understanding of tissue cultureinduced genome level changes in plants and potential applications. Plant cell reports 31:597620

Neill S, Barros R, Bright J, Desikan R, Hancock J, Harrison J, Morris P, Ribeiro D, Wilson I (2008) Nitric oxide, stomatal closure, and abiotic stress. Journal of Experimental Botany 59, $165-176$

Neven LG, Haskell DW, Guy CL, Denslow N, Klein PA, Green LG, Silverman A (1992) Association of 70-kilodalton heat-shock cognate proteins with acclimation to cold. Plant Physiol 99: 1362-1369

Niino T, Yamamoto SI, Fukui K, Castillo CR, Arizaga MV, Matsumoto T, Engelmann F (2013) Dehydration improves cryopreservation of mat rush (Juncus decipiens Nakai) basal stem buds on cryo-plates. CryoLetters 34:549-60 
Nishizawa S, Sakai A, Amano Y, Matsuzawa T (1993) Cryopreservation of asparagus (Asparagus officinalis L.) embryogenic suspension cells and subsequent plant regeneration by a simple freezing method. CryoLetters 13: 379-388

Padmini E, Valarmathi A, Rani MU (2010) Comparative analysis of chemical composition and antibacterial activities of Mentha spicata and Camella sinensis. Asian J Exp Biol 4:772781

Panis B, Lambardi M (2005) Status of cryopreservation technologies in plants (crops and forest trees. En: Ruane J, Sonnino A (eds) The role of biotechnology for the characterization and conservation of crop forest animal and fishery genetic resources in developing countries. Roma (Italia), pp 61-78

Panis B, Schoofs H, Remy S, Sági L, Swennen R (2000). Cryopreservation of banana embryogenic cell suspensions: an aid for genetic transformation. En Engelmann F, Takagi H (eds.) Cryopreservation of Tropical Plant Germplasm - current research progress and applications. JIRCAS/IPGRI, Tsukuba (Japón)/Roma (Italia)), pp 103-109

Paulet F, Engelmann F (1993) Cryoconservation of apices of sugar cane. En: Teisoon C (ed) In vitro culture of tropical plants. Repères Cirad (Francia) pp 11-13

Paulet F, Engelmann F, Glaszmann JC (1993) Cryopreservation of apices of in vitro plantlets of sugarcane (Saccharum sp. hybrids) using encapsulation/dehydration. Plant Cell Rep 12:525-529

Peredo EL, Arroyo-García R, Reed BM, Revilla MA (2008) Genetic and epigenetic stability of cryopreserved and cold-stored hops (Humulus lupulus L.) Cryobiology 57:234241

Phillips RL, Kaeppler SM, Olhof P (1994) Genetic instability of plant tissue cultures: Breakdown of normal controls. Proc Natl Acad Sci 91: 5222-5226

Pierik RLM (1987) In vitro culture of higher plants as a tool in the propagation of horticultural crops. International Symposium on Propagation of Ornamental Plants 226:25-40

Piña-Escutia JL, Vences-Contreras C, Gutiérrez-Martínez MG, Vázquez-García LM, Arzate-Fernández AM (2010) Caracterización morfológica y molecular de nueve variedades botánicas de Tigridia pavonia (Lf) DC. Agrociencia 44:147-158 
Rafique T, Yamamoto S, Fukui K, Mahmood Z, Niino T (2015) Cryopreservation of sugarcane using the V cryo-plate technique. CryoLetters 36:51-9.

Rani V, Raina SN (2000) Genetic fidelity of organized meristem-derived micropropagated plants: a critical reappraisal. In Vitro Cell. Dev Biol-Plant 36: 319-330

Rech EL, and Pires MJP (1986) Tissue culture propagation of Mentha spp. by the use of axillary buds. Plant Cell Rep 5:17-18

Redenbaugh K, Paasch BD, Nichol JW, Kossler ME, Viss PR, Walker KA (1986) Somatic seeds: Encapsulation of asexual plant embryos. Nature Biotechnology 4: 797-801

Reed BM (1993) Responses to ABA and Cold Acclimation Are Genotype Dependent for Cryopreserved Blackberry and Raspberry Meristems. Cryobiology 30:179-184

Reed BM (2002) Implementing cryopreservation for long-term germplasm preservation in vegetatively propagated species. En Towill LE, Bajaj YPS (eds) Cryopreservation of Plant Germplasm. Biotechnology in Agriculture and Forestry II. Springer-Verlag Berlin Heidelberg Nueva York, pp. 22-33

Reed BM (2008) Cryopreservation-practical considerations. En: Reed BM (ed) Plant Cryopreservation Ed Springer Nueva York, pp 3-13

Reed BM, Tanprasert P (1995) Detection and control of bacterial contaminants of plant tissue cultures. A review of recent literature. Plant tissue culture and Biotechnology 1:137142

Reinhoud PJ, Van-Iren F, Kijne W (2000) Cryopreservation of undifferentia ted plant cells. En Engelmann F, Takagi H (eds.) Cryopreservation of Tropical Plant Germplasm - current research progress and applications. JIRCAS/IPGRI, Tsukuba (Japón)/Roma (Italia), pp 91102

Rivas GM, y Berreta A (2001) Estrategia en recursos fitogenéticos para los países del Cono Sur. Instituto interamericano de cooperación para la agricultura (IICA) pp 1-140

Roach T, Ivanova M, Beckett RP, Minibayeva FV, Green I, Pritchard HW, Kranner I (2008) An oxidative burst of superoxide in embryonic axes of recalcitrant sweet chestnut seeds as induced by excision and desiccation. Physiologia Plantarum 133:131-139 
Rodríguez-Serrano M, Romero-Puertas MC, Zabalza A, Corpas FJ, Gómez M, del Río LA, Sandalio LM (2006) Cadmium effect on oxidative metabolism of pea (Pisum sativum L.) roots. Imaging of reactive oxygen species and nitric oxide accumulation in vivo. Plant Cell Environ. 29 1532-1544

Sakai A, Engelmann F (2007) Vitrification, encapsulation-vitrification and dropletvitrification: a review. CryoLetters 28:151-172

Sakai A, Hirai D, Niino T (2008) Development of PVS-based vitrification and encapsulation-vitrification protocols. En: Reed BM (ed.) Plant Cryopreservation. Ed. Springer, Nueva York, pp. 33-57

Sakai A, Kobayashi S, Oiyama I (1990) Cryopreservation of nucellar cell of navel orange (Citrus sinensis Obs. var. brasiliensis Tanaka) by vitrification. Plant Cell Reports 9:30-33

Sakai A, Matsumoto T, Hirai D, Niino T (2000) Newly developed encapsulationdehydration protocol for plant cryopreservation. CryoLetters 21:53-62

Salaj T, Matušíková I, Fráterová L, Piršelová B, Salaj, J (2011) Regrowth of embryogenic tissues of Pinus nigra following cryopreservation. Plant Cell Tiss Organ Cult 106:55-61

Salma M, Fki L, Engelmann-Sylvestre I, Niino T, Engelmann F (2014) Comparison of droplet-vitrification and D-cryoplate for cryopreservation of date palm (Phoenix dactylifera L.) polyembryonic masses. Sci Hortic 179:91-97

Sánchez E, García D, Carballo C, Crespo M (1996) Mentha x piperita. Revista Cubana de Plantas Medicinales 1: 40-45

Sánchez-Chiang N, Jiménez VM (2009) Técnicas moleculares para la detección de variantes somaclonales. Agronomía mesoamericana 20:135-151

Sánchez-Chiang, N, Jiménez VM (2010) Técnicas de conservación in vitro para el establecimiento de bancos de germoplasma en cultivos tropicales. agronomía mesoamericana 21:193-205

Sandalio LM, Rodríguez-Serrano M, Romero-Puertas MC, del Río LA (2008) Imaging of reactive oxygen species and NO in vivo in plant tissues. Methods Enzymol 440:399-409 
Schäfer-Menuhr A, Schumacher HM, Mix-Wagner G (1997) Cryopreservation of potato cultivars - design of a method for routine application in genebanks. Acta Horticulturae 447:447-482

Schenk RU, Hildebrandt AC (1972) Medium and techniques for induction and growth of monocotyledonous and dicotyledonous plant cell cultures. Can J Bot 50:199-204

Senula A, Keller J, Sanduijav T, Yohannes T (2007) Cryopreservation of cold-acclimated mint (Mentha spp.) shoot tips using a simple vitrification protocol. CryoLetters 28:1-12

Sevanian A, Kim E (1985) Phospholiphase $A_{2}$ dependent release of fatty acids from peroxidized membranes. Journal of free radicals in biology \& medicine 1:263-271

Silva DB, Vieira RF, Alves RBN, Mendes RA, Cardoso LD, Queiroz L, Santos IRI (2006) Mint (Mentha spp) germplasm conservation in Brazil. Rev Bras Pl Med Botucatu 8:27-31

Sisunandar S, Rival A, Samosir Y, Adkins S (2010) Cryopreservation of coconut (Cocos nucifera L.): The influence of embryo maturity upon rate of recovery and fidelity of seedlings. In Vitro Cell and Dev Biol Anim 46:2-3

Sivropoulou A, Kokkini S, Lanaras T, Arsenakis M (1995) Antimicrobial activity of mint essential oils. Journal of Agricultural and Food Chemistry 43:2384-2388

Smirnoff N, Wheeler GL (2000) Ascorbic acid in plants: biosynthesis and function. Critical Reviews in Biochemistry and Molecular Biology 35:291-314

Tabares E, Pachón J, Roca WM (1991) Variación Somaclonal y su aplicación al mejoramiento de cultivos. En: Roca WM, Mroginski LA (eds) Cultivo de tejidos en la agricultura: fundamentos y aplicaciones (Colombia), pp 339-359

Torres MA (2010) ROS in biotic interactions. Physiologia Plantarum 138:414-429

Towill LE (1990) Cryopreservation of isolated mint shoot tips by vitrification. Plant Cell Reports 9:178-180

Towill LE (2002) Cryopreservation of plant germplasm introduction and some observations. En: Towill LE, Bajaj YPS (eds) Cryopreservation of Plant Germplasm. Biotechnology in Agriculture and Forestry II Ed Springer-Verlag Berlin Heidelberg Nueva York,pp. 3- 21 
Towill LE, Walters C (2000) Cryopreservation of pollen. En Engelmann F, Takagi H (eds.) Cryopreservation of Tropical Plant Germplasm - current research progress and applications. JIRCAS/IPGRI, Tsukuba (Japón)/Roma (Italia), pp 115-129

Tucker AO (2012) Genetics and Breeding of the Genus Mentha: a Model for Other Polyploid Species with Secondary Constituents. Journal of Medicinally Active Plants 1:19-29

Turner S, Krauss SL, Bunn E, Senaratna T, Dixon K, Tan B, Touchell D (2001) Genetic fidelity and viability of Anigozanthos viridis following tissue culture cold storage and cryopreservation. Plant Science 161:1099-1106

Uchendu EE, Leonard SW, Traber MG, Reed BM (2010) Vitamins C and E improve regrowth and reduce lipid peroxidation of blackberry shoot tips following cryopreservation. Plant Cell Rep 29:25-35

Uchendu EE, Reed BM (2008) A comparative study of three cryopreservation protocols for effective storage of in vitro grown mint (Mentha spp.). CryoLetters 29: 181-188

Vázquez AM (2001) Insight into somaclonal variation. Plant Biosystems 135:57-62

Villalobos M, Engelmann F (1995) Ex situ conservation of plant germplasm using biotechnology. World Journal of Microbfology \& Biotechnology 11: 375-382

Volk GM, Harris JL, Rotindo KE (2006) Survival of mint shoot tips after exposure to cryoprotectant solution components. Cryobiology 52:305-308

Volk GM, Walters C (2006) Plant vitrifcation solution 2 lowers water content and alters freezing behavior in shoot tips during cryoprotection. Cryobiology 52:48-61

Vos P, Hogers R, Bleeker M, Reijans M, van de Lee T, Hornes M, Friters A, Pot J, Paleman J, Kuiper M, Zabeau M (1995) AFLP: a new technique for DNA fingerprinting. Nucleic acids research 23:4407-4414

Waldron J, Peace CP, Searle IR, Furtado A, Waden N, Findlay I, Graham MW, Carroll BJ (2002) Randomly Amplified DNA Fingerprinting: A Culmination of DNA Marker Technologies Based on Arbitrarily-Primed PCR Amplification. J Biomed Biotechnol 2:141150 
Wang ZC, Deng XX (2004) Cryopreservation of shoot-tips of citrus using vitrification: effect of reduced form of glutathione. CryoLetters 25:43-50

Waugh R, Power W (1992) Using RAPD markers for crop improvement. Trends in biotechnology 10:186-191

Weeden NF, Timmerman GM, Hemmat M, Kneen BE, Lodhi MA (1992) Inheritance and reliability of RAPD markers. In: Hoisington D, McNab A (eds) Applications of RAPD markers to plant breeding. Joint Plant Breeding Symposia Series, Crop Science Society of America, Minneapolis (Estados Unidos) pp 12-17

Weising K, Nybom H, Wolff K, Meyer W (1995) DNA fingerprinting in plants and fungi. CRC Press, 322 pp.

Welsh J, McClelland M (1990) Fingerprinting genomes using PCR with arbitrary primers. Nucleic Acids Res 18:7213-7218

Whitaker C, Beckett R, Minibayeva F, Kranner I (2010) Production of reactive oxygen species in excised desiccated and cryopreserved explants of Trichilia dregeana Sond. S Afr J Bo 76:112-8

Wilkinson T, Wetten A, Prychid C, Fay MF (2003) Suitability of cryopreservation for the long-term storage of rare and endangered plant species: a case history for Cosmos atrosanguineus. Ann Bot 91:65-74

Williams JGK, Kubelik AR, Livak KJ, Rafalsky A, Tingey SV (1990) DNA polymorphism amplified by arbitrary primers are useful as genetic markers. Nucleic Acids Res 18:6531-6535

Yamamoto S, Rafique T, Fukui K, Sekizawa K, Niino T (2012) V-cryo-plate procedure as an effective protocol for cryobanks: case study of mint cryopreservation. CryoLetters 33:1223

Yamamoto S, Rafique T, Priyantha WS, Fukui K, Matsumoto T, Niino T (2011) Development of a cryopreservation procedure using aluminium cryo-plates. CryoLetters $32: 256-65$

Zapata JI, Fernández GA (2011) Micropropagación de plantas de Mentha x piperita y evaluación de sus constituyentes volátiles. Revista Colombiana de Biotecnología 2:16-22 
Zeliang PK, Pattanayak A, Iangrai B, Khongwir EA, Sarma BK (2010) Fertile plant regeneration from cryopreserved calli of Oryza rufipogon Griff. and assessment of variation in the progeny of regenerated plants. Plant Cell Rep 29:1423-1433

Zhang JM, Huang B, Zhang XN, Volk GM, Zhou YC, Chen XL (2015) Identification of a highly successful cryopreservation method (droplet-vitrification) for petunia. In Vitro Cell Dev Biol-Plant 51:445-451 


\section{OBJETIVOS Y PLANTEAMIENTO}

El objetivo principal de esta tesis es profundizar en el conocimiento de los posibles efectos que los protocolos de crioconservación pueden causar en la estabilidad genética del material conservado de menta. Para ello se analizó el material después de la crioconservación mediante vitrificación-drolet y mediante encapsulación-deshidratación para detectar la posible aparición de cambios genéticos (mediante marcadores moleculares). También se evaluaron cada uno de los pasos de un protocolo de crioconservación, para determinar el nivel de estrés oxidativo que ejercen y los posibles daños que pueden estar produciendo durante el proceso.

Los objetivos parciales que se plantearon fueron los siguientes:

- Analizar la recuperación del material después de los protocolos de vitrificacióndroplet y encapsulación-desecación y detectar la posible aparición de cambios genéticos en el proceso (mediante marcadores moleculares).

- Evaluar la respuesta de dos genotipos de menta diferentes ante dos técnicas de crioconservación y tres medios de recuperación diferentes, determinando la estabilidad genética según el tipo de muestra recuperada.

- Determinar si la adición de antioxidantes en una de las etapas del proceso de crioconservación tiene como efectos el aumento de la recuperación y la mantención de la estabilidad genética del material vegetal.

- Analizar cada uno de los diversos pasos de un protocolo de crioconservación para evaluar la estabilidad genética y, si es posible, relacionar el proceso que se esté llevando a cabo con el posible cambio detectado.

- Obtener base científica que apoye la hipótesis donde la inmersión en nitrógeno líquido no sería el único factor que provoca lesiones en los tejidos durante el proceso de crioconservación.

- Desarrollar protocolos de crioconservación de menta que eviten o disminuyan el efecto negativo del estrés oxidativo provocado por esta técnica. 


\section{MATERIALES Y MÉTODOS GENERALES}

\subsection{Material vegetal}

El trabajo se llevó a cabo con dos accesiones de menta (Mentha $\times$ piperita L.) del banco de germoplasma del IPK (Leibniz Institute of Plant Genetics and Crop Plant Research, Gatersleben, Alemania): 'MEN 186'y 'MEN 198'. Las accesiones fueron recolectadas en Güira de Melea, Habana (Cuba) en 1990 y en Johanneskirchen (Alemania) en 1992, respectivamente. El banco de germoplasma del IPK mantenía desde 1997 los cultivos in vitro en medio MS con $3 \%$ sacarosa, sin reguladores de crecimiento, en recipientes de vidrio con 5 vástagos cada uno, a $2{ }^{\circ} \mathrm{C}$ con un fotoperiodo de $16 \mathrm{~h}$ y $2-4 \mathrm{~mol} \mathrm{~m}^{-2} \mathrm{~s}^{-1}$ de densidad de flujo de fotones fotosintéticos (Photosynthetic Photon Flux Density, PPFD); los vástagos se subcultivaban periódicamente cada 2 años (Martín et al. 2013).

Se recibieron 5 vástagos por accesión en noviembre del 2009, que se multiplicaron (ver siguiente apartado) hasta obtener material suficiente para iniciar los experimentos en abril del 2010.

\subsection{Cultivo in vitro}

Para mantener la colección recibida del IPK y disponer del material suficiente para llevar a cabo los sucesivos experimentos, los vástagos fueron subcultivados mensualmente en medio MS (Murashige y Skoog 1962), sin reguladores del crecimiento, y suplementado con $3 \%$ de sacarosa. El medio fue solidificado con agar (agar bacteriológico Americano, CONDA) al $0,7 \%$. El pH fue ajustado entre 5,7 y 5,8. Para el cultivo se emplearon recipientes de vidrio de $580 \mathrm{ml}$ de capacidad ( $89 \mathrm{~mm}$ diámetro) que, tras añadir $50 \mathrm{ml}$ de medio de cultivo, fueron esterilizados en autoclave a 1 atm. de presión durante 20 minutos. Se cultivaron cinco vástagos por tarro. Los cultivos de menta (Fig. 3.1 A) se incubaron a $25{ }^{\circ} \mathrm{C}$, con un fotoperiodo de $16 \mathrm{~h}$ luz y a una PPFD de $50 \mu \mathrm{mol} \mathrm{m} \mathrm{m}^{-2} \mathrm{~s}^{-1}$, proveniente de tubos fluorescentes de luz fría blanca. A partir de esos vástagos se obtuvieron los segmentos nodales (Fig. 3.1 B-C) de donde después de 3 semanas de endurecimiento en frío a $25^{\circ} \mathrm{C} 16 \mathrm{~h} /-1{ }^{\circ} \mathrm{C} 8 \mathrm{~h}$ se extraían los ápices caulinares (Fig. 3.1 D) para los distintos experimentos. 


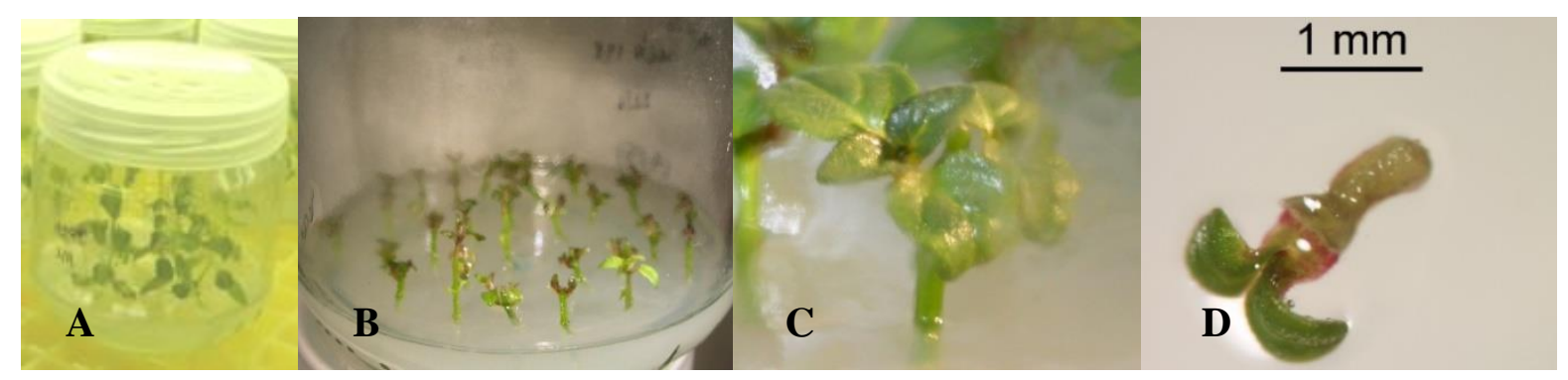

Figura 3.1. A) Vástagos cultivados in vitro, B y C) segmentos nodales y D) ápice correspondiente a la accesión 'MEN 198'.

\subsection{Descripción de los experimentos}

\subsubsection{Influencia de la técnica de crioconservación, medio de recuperación y el genotipo en la recuperación y la estabilidad genética de ápices de menta crioconservados}

En estos experimentos se estudiaron el efecto de la técnica de crioconservación (encapsulación-deshidratación y vitrificación-droplet), del genotipo ('MEN 186' y 'MEN 198') y de los reguladores de crecimiento empleados sobre la regeneración y la estabilidad genética de los ápices (Fig. 3.2). Se analizaron los ápices recuperados después de su inmersión en NL ("+") y ápices sin crioconservar, es decir, sometidos a todos los pasos de pretratamiento correspondientes a los protocolos de crioconservación a excepción de la inmersión en NL (“-NL”) y utilizados como controles del efecto del NL en el proceso. Para la recuperación de los explantos se utilizaron tres medios de cultivo con distintas concentraciones de reguladores de crecimiento: 1) $0,5 \mathrm{mgL}^{-1}$ 6-bencilaminopurina (BAP; Uchendu y Reed 2008), 2) 0,5 $\mathrm{mgL}^{-1}$ 6-dimetilalilamino-purina (2iP) + 0,1 $\mathrm{mgL}^{-1}$ ácido $\alpha$ naftalen-acético (ANA; Senula et al. 2007); y 3) 0,5 $\mathrm{mgL}^{-1} \mathrm{BAP}+0,1 \mathrm{mgL}^{-1} \mathrm{ANA}$. Estos medios fueron nombrados "Reed", "Senula" (por los autores de cada uno) y "Nudos" (medio utilizado en nuestro laboratorio).

La estabilidad genética del material vegetal obtenido se analizó mediante marcadores RAPDs. Como control para el análisis molecular se incluyeron muestras de hojas provenientes de vástagos cultivados in vitro de cada genotipo. Para la extracción de ADN se tomaron muestras después de 4 u 8 semanas de recuperación de los explantos supervivientes tras los protocolos de crioconservación dependiendo del experimento. Las muestras se obtuvieron a partir de hojas, o bien del pequeño callo basal que a veces aparecía en los 
explantos, y también a partir de aquellos que sólo desarrollaron callo después de los tratamientos, dependiendo de la respuesta de los explantos. En el genotipo 'MEN 198' se utilizaron 15 a 22 muestras por combinación de medio y técnica, lo que representó entre el $22,4 \%$ y el $68,7 \%$ de los explantos supervivientes. En un experimento separado, se analizaron muestras de 'MEN 186' en ambas técnicas de crioconservación (18 y 20 muestras, respectivamente; lo que representaba entre el 28,6 \% y el 55,5\% de los explantos supervivientes) y recuperados sólo en medio "Reed". En estos dos experimentos, el material vegetal se recogió después de 4 semanas en cultivo.

Con el fin de estudiar más a fondo el comportamiento de los ápices después del protocolo de encapsulación-deshidratación, se estudió la estabilidad genética de las muestras recuperadas en los tres medios de recuperación en ambos genotipos después de un período de cultivo de 8 semanas; se analizaron de 12 a 16 muestras por combinación de genotipo y medio (entre el 44,4\% y el 72,2\% de los explantos supervivientes).

\subsubsection{Efecto de sustancias antioxidantes en la recuperación y estabilidad genética después de la crioconservación mediante encapsulación-deshidratación}

A partir de los resultados obtenidos en el experimento de medios de regeneración, se determinó que los siguientes experimentos se centrarían en la técnica de encapsulacióndeshidratación y utilizando el medio "Senula" para la recuperación de los ápices.

Se estableció un experimento para determinar el efecto de la adición de antioxidantes en el precultivo de ápices en 0,3 M sacarosa (Fig. 3.3) sobre la recuperación y la variabilidad genética generada en el protocolo de crioconservación. Se estudiaron ambos genotipos, 'MEN 198' y 'MEN 186'. Se añadieron al medio de precultivo glutatión, ácido ascórbico o $\alpha$-tocopherol (Vitamina E). Se evaluó la supervivencia y regeneración de los ápices a las 8 semanas tras su recuperación, tanto de los crioconservados como de aquellos que fueron sometidos a todos los pasos correspondientes a los protocolos de crioconservación a excepción de la inmersión en NL ("-NL"), y se extrajeron muestras de brotes y callos para la extracción de ADN. Las muestras se obtuvieron a partir de hojas, del pequeño callo basal que a veces aparecía en los explantos, y también a partir de explantos que sólo desarrollaron callo después de los tratamientos, dependiendo de la respuesta de los explantos. El análisis de la estabilidad genética se realizó mediante marcadores RAPDs y AFLPs. 


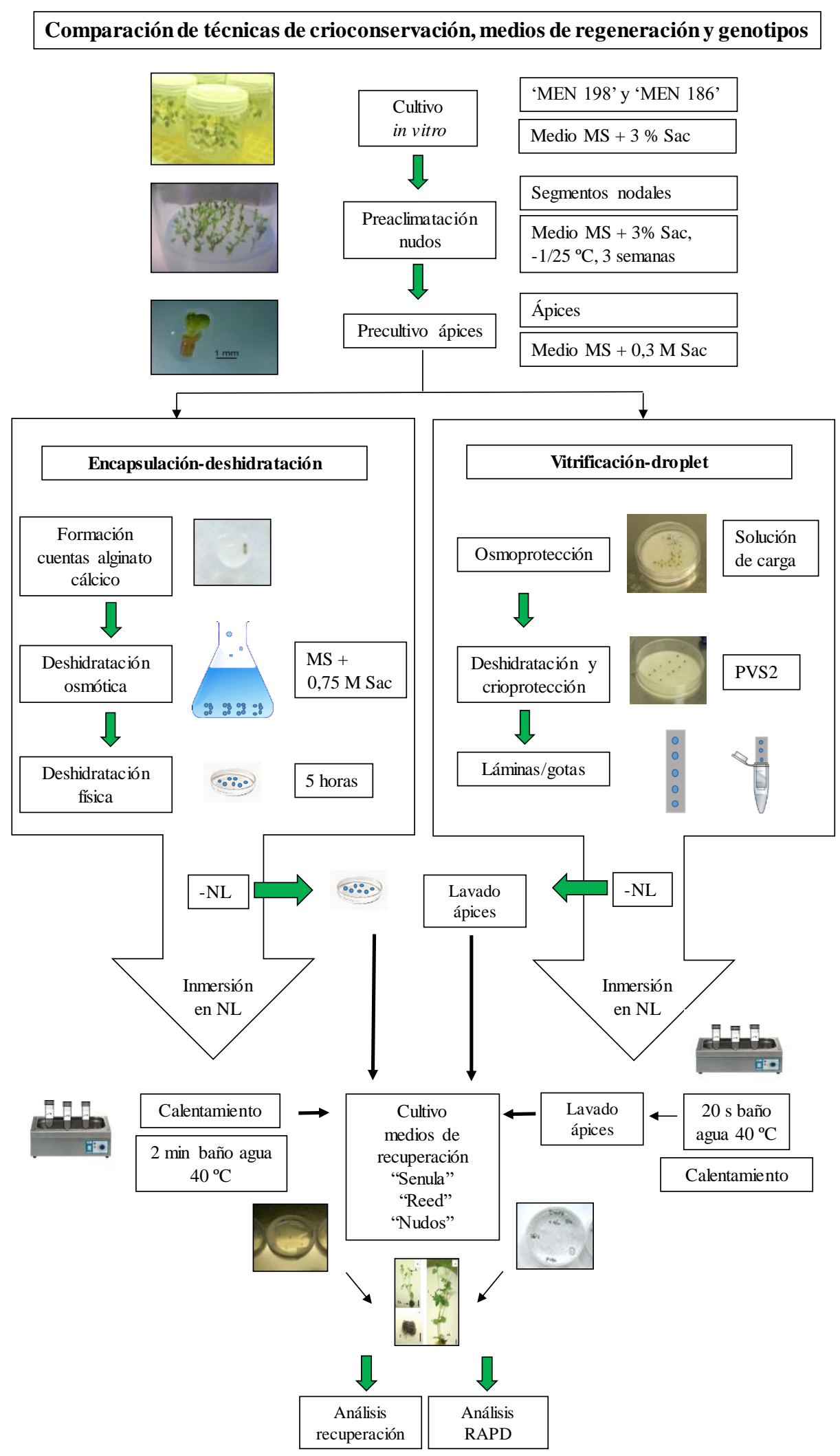

Figura 3.2. Esquema del experimento "Influencia de la técnica de crioconservación, medio de recuperación y el genotipo en la recuperación y la estabilidad genética de ápices de menta crioconservados". 


\section{Efecto de tratamientos antioxidantes en precultivo de ápices en encapsulación-} deshidratación
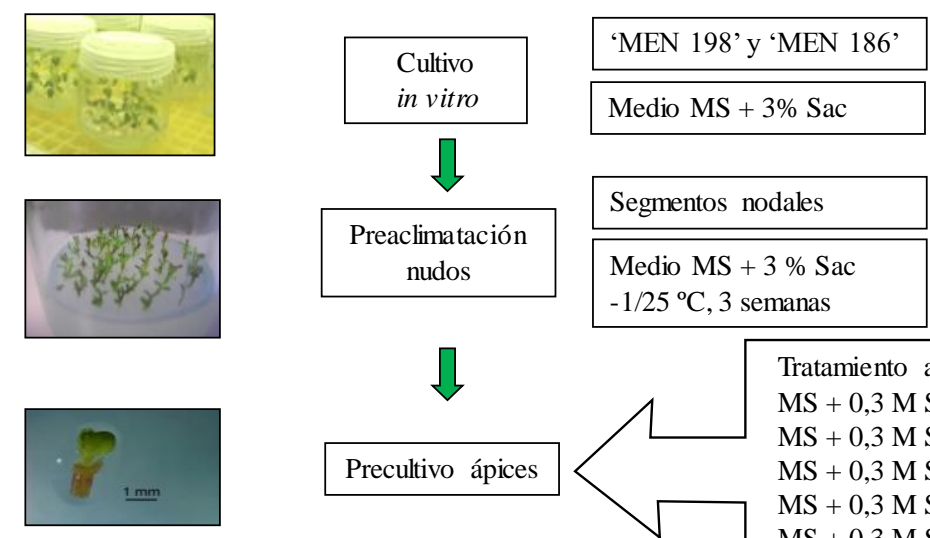

\begin{tabular}{|l|}
\hline Segmentos nodales \\
\hline Medio MS $+3 \%$ Sac \\
$-1 / 25^{\circ} \mathrm{C}, 3$ semanas \\
\hline
\end{tabular}

$-1 / 25^{\circ} \mathrm{C}, 3$ semanas
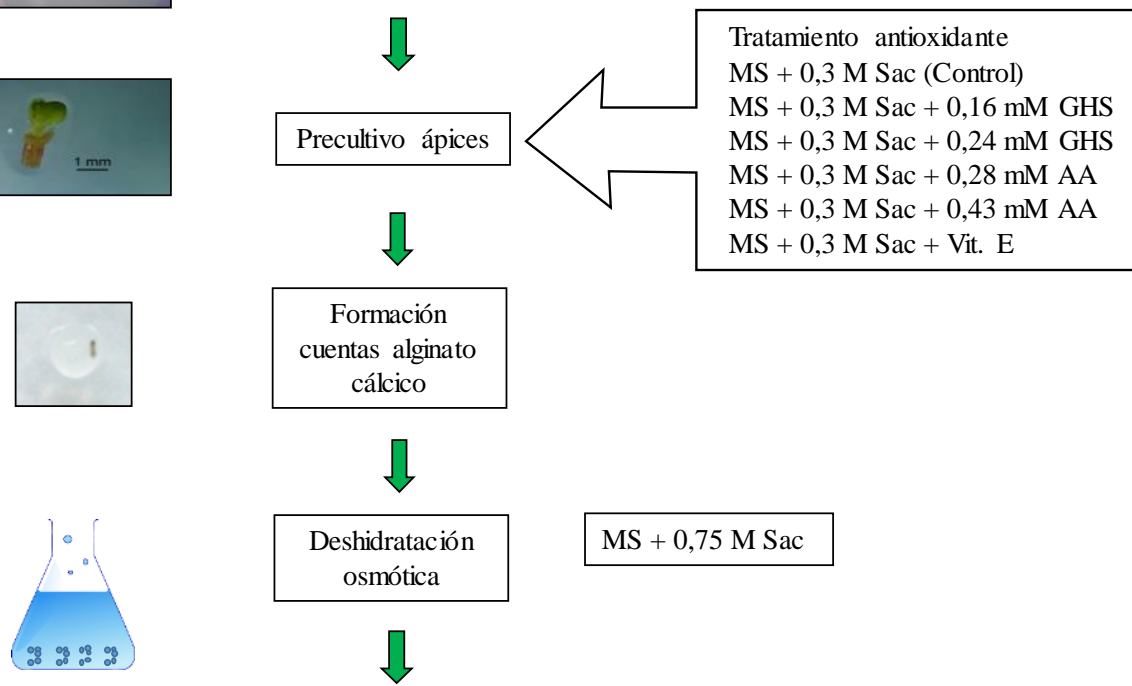

$\mathrm{MS}+0,75 \mathrm{M} \mathrm{Sac}$
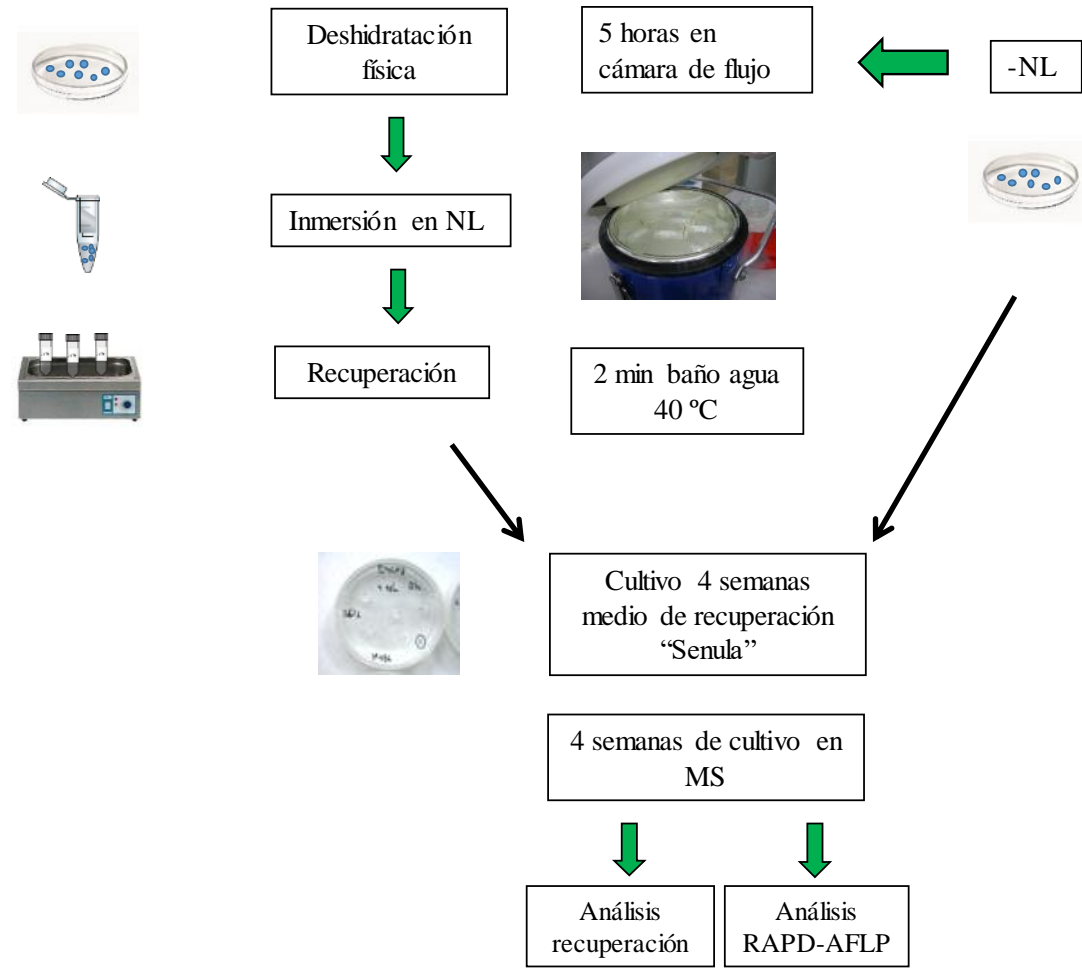

Figura 3.3. Esquema del experimento "Efecto de sustancias antioxidantes en la recuperación y estabilidad genética después de la crioconservación mediante encapsulacióndeshidratación". 


\subsubsection{Efecto de sustancias antioxidantes en la recuperación y estabilidad genética después de cada paso del protocolo de crioconservación mediante encapsulación- deshidratación}

En este tercer experimento se estudió por separado cada paso del procedimiento de crioconservación por encapsulación-deshidratación para determinar la evolución de la estabilidad genética y el nivel de oxidación generado a lo largo del procedimiento de crioconservación. Las etapas estudiadas fueron nombradas de la siguiente forma: precultivo y aclimatación de los segmentos nodales (“N”); precultivo de ápices (“P”); cultivo de los ápices encapsulados (“S”); deshidratación de las cuentas (“D”) y enfriamiento en nitrógeno líquido (“Cr"). Como control se utilizaron hojas provenientes de cultivo in vitro (“A”) o ápices extraídos de segmentos nodales sin aclimatación (Fig. 3.4). El genotipo estudiado fue 'MEN 198' y el medio de recuperación fue "Senula".

Se estudió el efecto de la adición de antioxidantes $(0,43 \mathrm{mM}$ de ácido ascórbico o vitamina E) a la solución de precultivo de ápices (etapa "P") en la recuperación y la estabilidad genética. Se realizó el análisis de supervivencia y recuperación de los explantos a las cuatro y ocho semanas tras cada paso de la crioconservación. Para el estudio de la variabilidad genética mediante marcadores moleculares RAPDs y AFLPs se tomaron las muestras en la octava semana de recuperación. Se utilizaron de 12 a 21 muestras por combinación de antioxidante y etapa de la crioconservación.

Se realizó un estudio con sondas fluorescentes para determinar la generación de ROS y NO durante algunas de las etapas del proceso de crioconservación por encapsulacióndeshidratación (Fig. 3.5). Se comparó el efecto de la incorporación de ácido ascórbico $(0,43 \mathrm{mM})$ en las etapas "P" $\mathrm{y}$ "S".

Por otro lado, se analizaron muestras para determinar la presencia de malondialdehído (MDA) en cada una de ellas (Fig. 3.5). El MDA es uno de los productos que se forman por la peroxidación de los ácidos grasos poli-insaturados y es un indicador del nivel de oxidación (Uchendu et al. 2010). Se incorporó 0,43 $\mathrm{mM}$ de ácido ascórbico, como agente antioxidante, en las etapas "P" y "S", al igual que en el estudio por sondas fluorescentes. 
Para tener un valor de la capacidad antioxidante presente en las hojas de menta utilizadas en este estudio, se utilizó el método ABTS. En el análisis se comparó la actividad antioxidante de los dos genotipos de menta, tanto de hojas de plantas aclimatadas en maceta, como de plantas in vitro. También se estudió el efecto de la utilización de polivilpolipirrolidona (PVPP) durante la extracción del material vegetal, para la eliminación de compuestos fenólicos que pudieran interferir en la medición. 
Efecto de los tratamientos antioxidantes en el precultivo de ápices en los pasos del protocolo de encapsulación-deshidratación
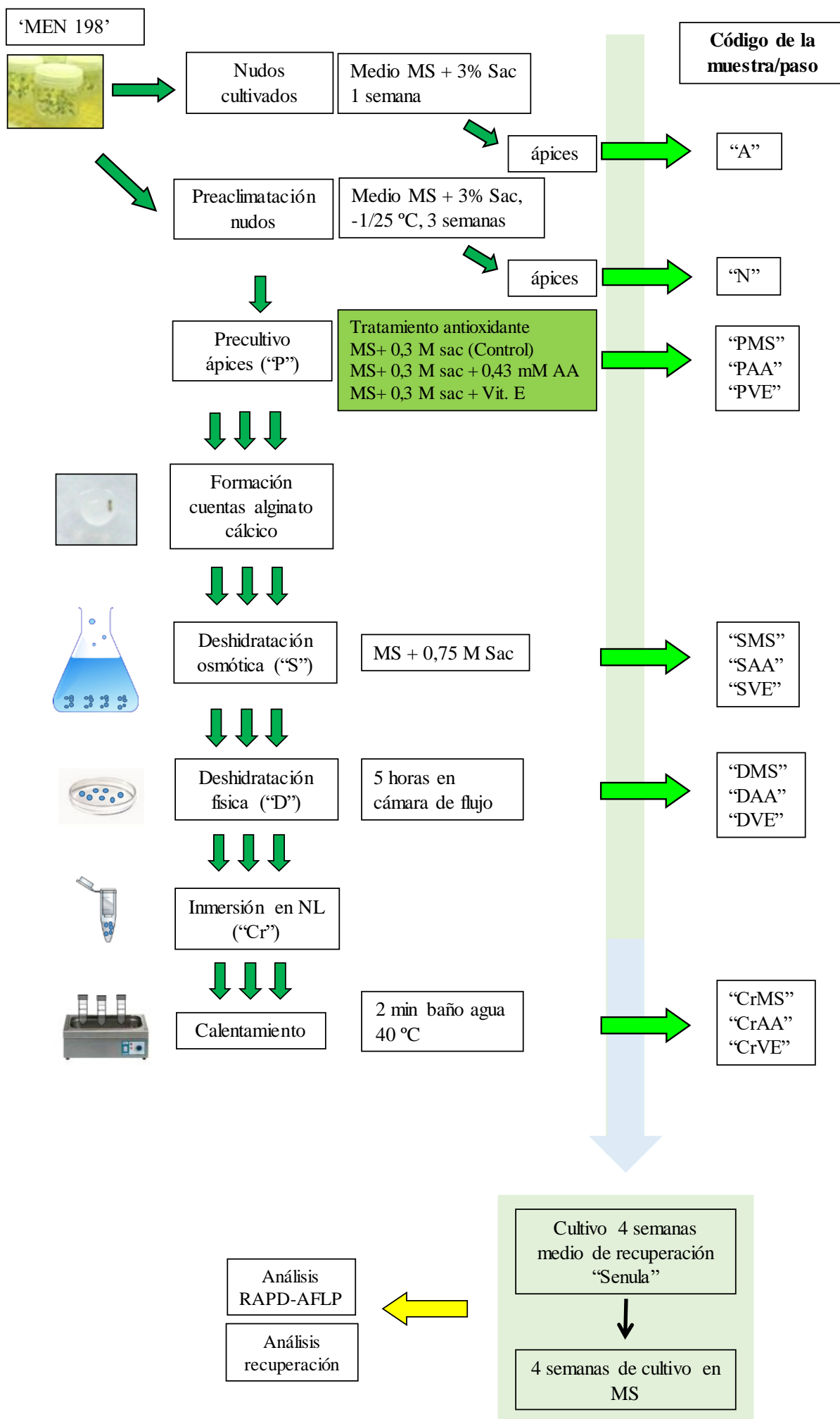

Figura 3.4. Esquema de experimento "Efecto de sustancias antioxidantes en la recuperación y estabilidad genética después de cada paso del protocolo de crioconservación mediante encapsulación-deshidratación” (análisis molecular y de recuperación de ápices). 


\section{Efecto de tratamientos antioxidantes en encapsulación-deshidratación, estudio de} ROS y NO y formación de MDA

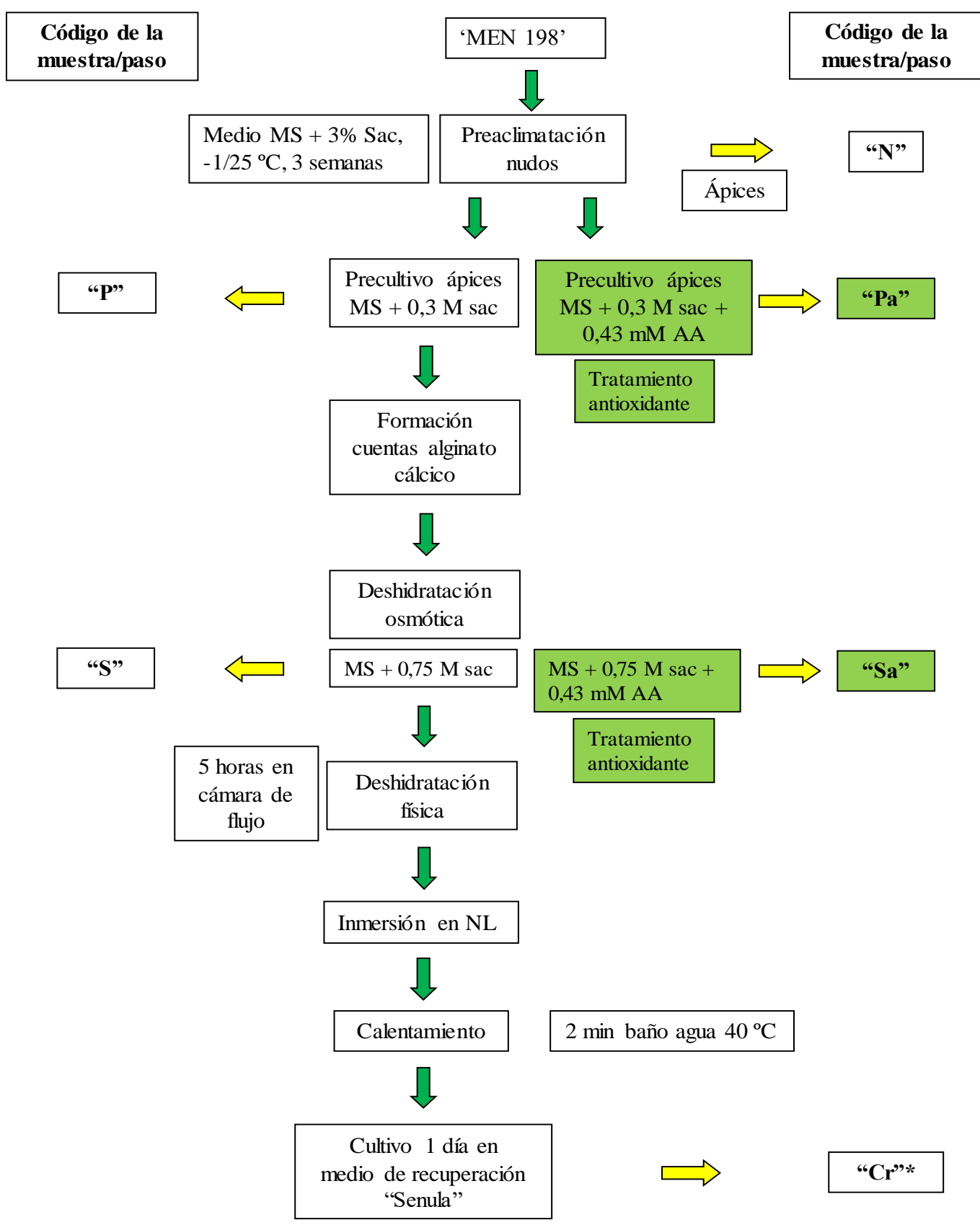

* En el estudio de MDA también se incluyeron muestras procedentes de material en cultivo in vitro ("A") y crioconservadas que habían sido tratadas con 0,43 mM ác. Ascórbico en el paso "P" ("Crp") o en el paso "S" ("Crs").

Figura 3.5. Esquema de experimento "Efecto de sustancias antioxidantes en la recuperación y estabilidad genética después de cada paso del protocolo de crioconservación mediante encapsulación-deshidratación” (análisis ROS, NO y MDA). 


\subsection{Bibliografía}

Martín C, Senula A, González I, Acosta A, Keller ERJ, González-Benito ME (2013) Genetic identity of three mint accessions stored by different conservation procedures: field collection in vitro and cryopreservation. Genet Resour Crop Evol 60:243-249

Murashige T, Skoog F (1962) A revised medium for rapid bioassays with tobacco tissue cultures. Physiologia Plantarum 15: 473-497

Senula A, Keller J, Sanduijav T, Yohannes T (2007) Cryopreservation of cold-acclimated mint (Mentha spp.) shoot tips using a simple vitrification protocol. CryoLetters 28:1-12

Uchendu EE, Leonard SW, Traber MG, Reed BM (2010) Vitamins C and E improve regrowth and reduce lipid peroxidation of blackberry shoot tips following cryopreservation. Plant Cell Rep 29:25-35

Uchendu EE, Reed BM (2008) A comparative study of three cryopreservation protocols for effective storage of in vitro grown mint (Mentha spp.). CryoLetters 29: 181-188 


\section{INFLUENCE OF THE CRYOPRESERVATION TECHNIQUE, RECOVERY MEDIUM AND GENOTYPE ON RECOVERY AND GENETIC STABILITY OF MINT CRYOPRESERVED SHOOT TIPS}

\subsection{Regeneration in mint (Mentha $\times$ piperita L.) cryopreserved apices: can the cryopreservation technique, recovery medium composition and genotype affect the final result? ${ }^{1}$}

\subsubsection{Abstract}

One of the most reliable methods for long-term conservation is cryopreservation, mainly due to its capability to guarantee the genetic stability of the preserved material. During the development of cryopreservation protocols, the composition of the growth recovery medium is of vital importance in order to obtain fully viable structures without callus formation. Two cryopreservation techniques (droplet-vitrification and encapsulationdehydration) and three different recovery media were compared with shoot apices of two mint genotypes ('MEN186' and 'MEN198'). The medium was supplemented with: 1) $0.5 \mathrm{mgL}^{-1} 6$ benzylaminopurine; 2) $0.5 \mathrm{mgL}^{-1}$ 6-dimethylallylamino-purine $+0.1 \mathrm{mgL}^{-1} \alpha$-naphthalene acetic acid; or 3) $0.5 \mathrm{mgL}^{-1}$ 6-benzylaminopurine $+0.1 \mathrm{mgL}^{-1} \alpha$-naphthalene acetic acid. Survival and recovery (shoot growth) were studied after a 4-week recovery period. Although the recovery media did not influence survival in any of the two genotypes or protocols, the recovery percentage observed was affected by the growth regulators. When the encapsulationdehydration protocol was employed this influence was detected even in control apices (no subjected to cooling in liquid nitrogen), while with the droplet-vitrification method recovery medium had an effect only on cryopreserved apices. In all these cases, the medium without auxin (only with cytokinin) resulted in higher recovery rates, i.e. organized growth was favoured.

Keywords: droplet, encapsulation-dehydration, growth regulators, liquid nitrogen, vitrification.

${ }^{l}$ This section reproduces the text of the manuscript: Kremer C, Martín C, González I, González-Benito ME. Acta Horticulturae (in press). 


\subsubsection{Introduction}

Aromatic plants have experimented in the last years an increased attention and importance as crops due to their demand by consumers for culinary, medicinal and other applications. In this context, search of wild genotypes, breeding programmes and genotype conservation are some of the tasks involved in the development of the production of these species.

One of the most reliable methods for long-term conservation is cryopreservation, mainly due to its capability to guarantee the genetic stability of the preserved material during the process (Martin et al. 2012). However, the stresses suffered due to the treatments applied together with the in vitro culture, required for the regeneration of the plant material, may affect the quality and quantity of the response after cryopreservation. Several steps of cryopreservation protocols should be optimized before the application of these techniques to a given species (or even a specific genotype). The aim is not only to obtain high survival after recovery but fully viable structures, i.e. shoot apices growing into shoots without callus formation. The treatments applied to plant material in order to optimize cryopreservation protocols impose stresses that may produce cell damages. This could make necessary to optimize the recovery conditions after removal from liquid nitrogen (or the vapour phase). Besides the environmental conditions (e.g. irradiance), the composition of the growth recovery medium is also important. In some species the removal of auxins led to a reduction of callus formation (Chang and Reed 1999). However, the study of the genetic stability of cryopreserved material should also be considered (Harding 2004, Martín and González-Benito 2005, Martín et al. 2011).

Mint (Mentha x piperita L.) is an unfertile hybrid with clonal propagation; this makes cryopreservation a very useful conservation technique, avoiding the risks related to field collections and time consuming and labour costs of in vitro conservation (Martin et al. 2012). Cryopreservation conditions must be controlled to guarantee an adequate regeneration rate and the quality of the recovered material. 


\subsubsection{Material and Methods}

\subsubsection{Plant Material and Preconditioning Treatments}

This work was carried out with two mint accessions (Mentha xpiperita L.) received from the genebank of IPK (Leibniz Institute of Plant Genetics and Crop Plant Research, Gatersleben, Germany), namely 'MEN186' and 'MEN198'. Shoots were micropropagated for two years in our laboratory by monthly subcultures on MS medium (Murashige and Skoog 1962), $\mathrm{pH}$ 5.7-5.8, with $3 \%$ sucrose and no growth regulators, and incubated at $25{ }^{\circ} \mathrm{C}$, with a $16 \mathrm{~h}$ photoperiod and an irradiance of $50 \mu \mathrm{mol} \mathrm{m} \mathrm{m}^{-2}$.

Nodal segments were excised from the in vitro shoots and cultured on MS medium supplemented with sucrose $(3 \%)$, and incubated for 3 weeks at $25^{\circ} \mathrm{C}$ (light) $/-1{ }^{\circ} \mathrm{C}$ (dark) with a photoperiod of $16 \mathrm{~h}$ and irradiance of $50 \mu \mathrm{mol} \mathrm{m} \mathrm{m}^{-2} \mathrm{~s}^{-1}$. Subsequently, apices (approx. $2 \mathrm{~mm}$ long) were excised, transferred to liquid MS medium supplemented with $0.3 \mathrm{M}$ sucrose, and cultured at $25{ }^{\circ} \mathrm{C}$ for one day, with an irradiance of approximately $10 \mu \mathrm{mol} \mathrm{m} \mathrm{m}^{-2} \mathrm{~s}^{-1}$.

\subsubsection{Cryopreservation by Encapsulation-Dehydration}

Pre-conditioned apices were immersed in a $3 \%$ alginate solution prepared with MS liquid medium with $0.4 \mathrm{M}$ sucrose. Drops of this solution, each one containing an apex, were dispensed in liquid MS medium containing $100 \mathrm{mM} \mathrm{CaCl}_{2}$ and $0.4 \mathrm{M}$ sucrose. The formed beads were maintained in that solution for approximately half an hour. Subsequently, beads were cultured in MS liquid medium containing $0.75 \mathrm{M}$ sucrose, at $130 \mathrm{rpm}$, for 16-18 h. After that period, beads were removed the excess of liquid dried from the surface with sterile filter paper, and placed on open Petri dishes to be dried for $5 \mathrm{~h}$ under the flow of a laminar-flow bench (to approximately $20 \%$ water content fresh weight basis). Beads were then included in cryovials (five beads per cryovial) and rapidly immersed in liquid nitrogen (LN), and kept there for at least one day. Warming took place in a water bath at $40{ }^{\circ} \mathrm{C}$, for approximately 2 min. Beads were then cultured on the three recovery media tested. Apices that had been subjected to all procedures except immersion in LN were used as controls (Fig. 4.1). 


\subsubsection{Cryopreservation by Droplet-Vitrification}

A modified protocol of Senula et al. (2007) was used. Pre-conditioned apices were immersed in a loading solution (MS liquid medium $+2 \mathrm{M}$ glycerol $+0.4 \mathrm{M}$ sucrose), for 20 min at room temperature. After that, apices were maintained in the vitrification solution PVS2 (30\% w/v glycerol, $15 \% \mathrm{w} / \mathrm{v}$ ethylene glycol, 15\% w/v dimethyl sulfoxide and $0.4 \mathrm{M}$ sucrose in liquid MS medium; Sakai et al. 1990) on ice (approx. $0{ }^{\circ} \mathrm{C}$ ) for 30 min. Finally, apices were placed into droplets $(2 \mu \mathrm{L})$ of PVS2 on aluminium foil strips (five apices per strip). These were included into cryovials and immersed in liquid nitrogen (LN), for at least one day. Warming took place by placing the cryovials in a water bath at $40{ }^{\circ} \mathrm{C}$ for 20 seconds. Subsequently, $1 \mathrm{~mL}$ of rinsing solution (1.2 M sucrose in MS) was added to each cryotube. The tubes were slightly shaken, and the content was transferred into Petri dishes with $2 \mathrm{~mL}$ of rinsing solution and kept at room temperature for $20 \mathrm{~min}$. Apices were then cultured on the three recovery media tested. Apices that had been subjected to all procedures except immersion in LN were used as controls (Fig. 4.1).

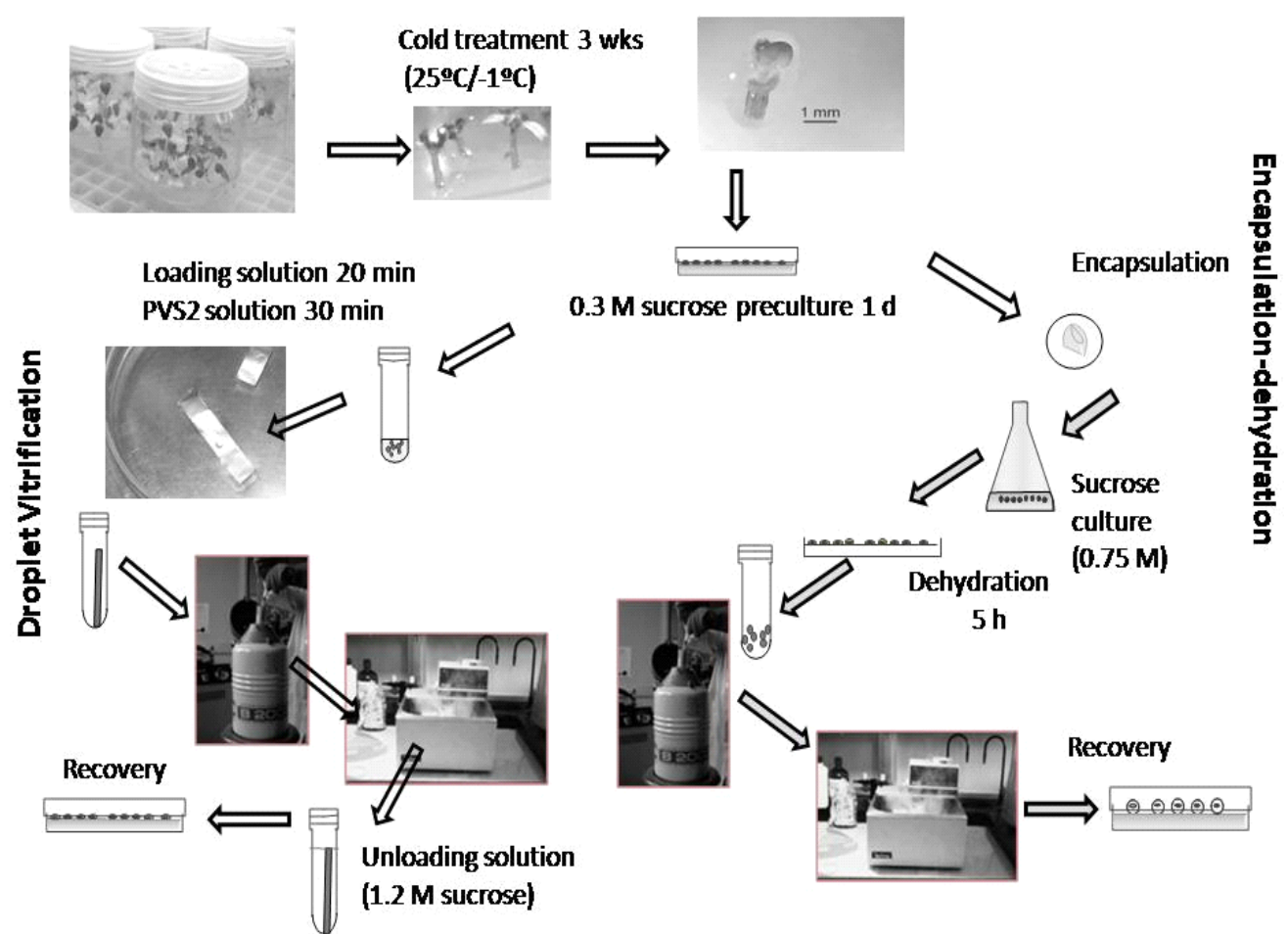

Figure 4.1. Cryopreservation procedure by encapsulation-dehydration and dropletvitrification. 


\subsubsection{Recovery}

Beads/apices from both cryopreservation protocols were cultured on MS semisolid medium supplemented with the following growth regulators: 1) $0.5 \mathrm{mg} / \mathrm{L}$ 6benzylaminopurine (BAP; Uchendu and Reed 2008), 2) $0.5 \mathrm{mgL}^{-1}$ 6-dimethylallylaminopurine (2-iP) + $0.1 \mathrm{mgL}^{-1} \alpha$-naphthalene acetic acid (NAA; Senula et al. 2007); and 3) 0.5 $\mathrm{mgL}^{-1} \mathrm{BAP}+0.1 \mathrm{mgL}^{-1} \mathrm{NAA}$. These media were named "Reed", "Senula" and "Nodes", respectively. Cultures were incubated at $25{ }^{\circ} \mathrm{C}$, the first $24 \mathrm{~h}$ under darkness followed by 20 days with an irradiance of approximately $10 \mu \mathrm{mol} \mathrm{m} \mathrm{m}^{-2} \mathrm{~s}^{-1}$ and then transferred to $50 \mu \mathrm{mol}$ $\mathrm{m}^{-2} \mathrm{~s}^{-1}$.

\subsubsection{Data analysis}

Each replicate consisted of five apices and 6-10 replicates were used per combination of cryopreservation procedure and recovery medium, per genotype. Survival and recovery (expansion of leaves and elongation of shoot) data were recorded after four weeks of culture on the recovery media. Analysis of variance was performed after arcsin transformation of data and means were compared by Duncan's Multiple Range Test $(\mathrm{p}<0.05)$.

\subsubsection{Results and Discussion}

The analysis of variance showed that the effect of the cryopreservation protocol, genotype and recovery medium on survival percentages in control (not submitted to LN) apices was not significant. However, medium, method, and their interaction, had a significant effect on recovery in control apices. As a whole, for both genotypes, the recovery results obtained after encapsulation-dehydration were significantly lower than with the droplet-vitrification except when the 'Reed' was the medium employed in controls (Figs. 4.2 and 4.3). 
A

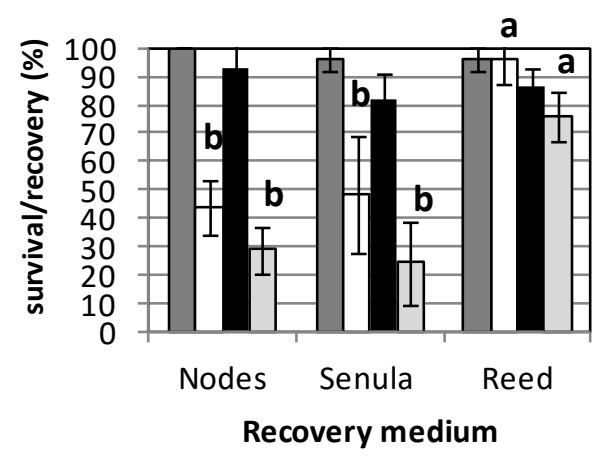

B

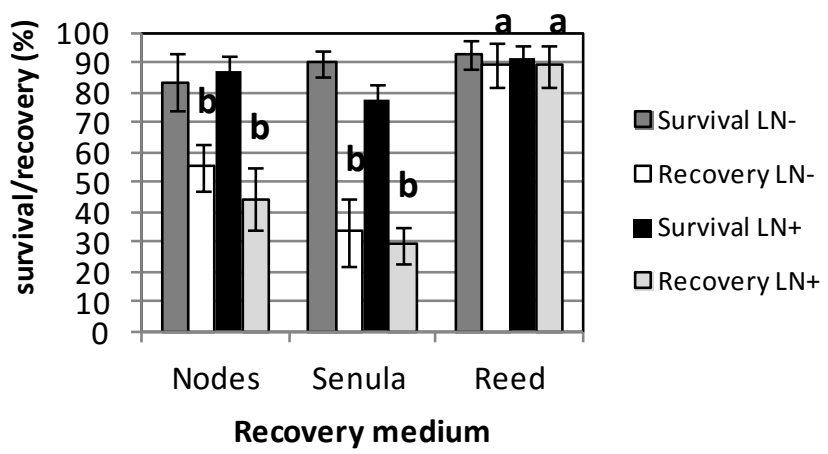

Figure 4.2. Survival and recovery percentages obtained after a 4-week culture period of mint apices of genotype 'MEN186' (A) and 'MEN198' (B) subjected to the encapsulationdehydration protocol. LN-: control apices not immersed in liquid nitrogen; LN+: apices immersed in liquid nitrogen. Bars: standard error. Within type of response, treatment (LN-, $\mathrm{LN}+$ ) and genotype, means with the same letter are not significantly different according to Duncan's Multiple Range Test $(\mathrm{p}<0.05)$; means without letters were not significantly different.

A

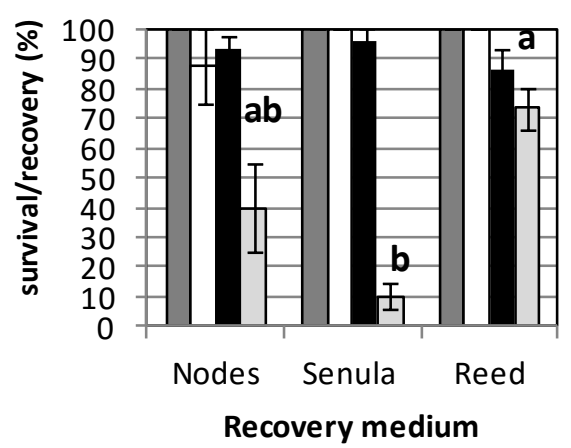

B

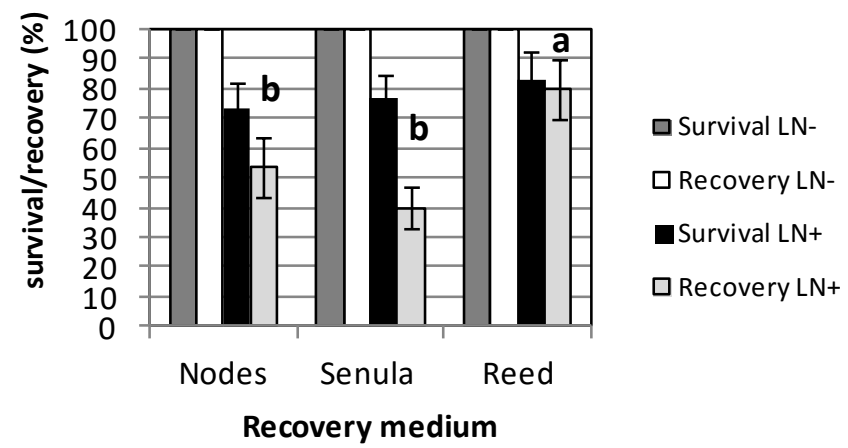

Figure 4.3. Survival and recovery percentages obtained after a 4-week culture period of mint apices of genotype 'MEN186' (A) and 'MEN198' (B) subjected to the dropletvitrification protocol. LN-: control apices not immersed in liquid nitrogen; LN+: apices immersed in liquid nitrogen. Bars: standard error. Within type of response, treatment (LN-, $\mathrm{NL}+$ ) and genotype, means with the same letter are not significantly different according to Duncan's Multiple Range Test $(\mathrm{p}<0.05)$; means without letters were not significantly different. 
Survival percentages in cryopreserved apices showed significant differences between the two genotypes, while medium and protocol employed did not affect the results. The analyses of recovery data revealed similar results for both methods. However, medium and genotype had a significant effect on the recovery percentage without significant interactions between the three factors.

When the analysis of variance (and comparison of means) was carried out for each genotype and cryopreservation protocol (Figs. 4.2 and 4.3) the recovery percentages obtained on "Reed" medium were higher than on the other two media tested for both genotypes. For both procedures and genotypes recovery responses obtained on "Reed" medium were higher than $70 \%$.

Different steps of cryopreservation protocols may induce damages and these may stimulate callus formation. In addition, plant growth regulators, in particular auxins, may favor the production of callus. This response can affect the development of the tissues and further regeneration after recovery. Combination of cryopreservation procedure and media composition may interact and result in a different response, as we have seen in those samples culture with "Reed" medium. For this reason, the composition of the recovery medium should be an important parameter of the cryopreservation protocols to be optimized. Cryopreserved shoot tips (exposed to NL) may have suffered more stress and been more damaged than control ones, therefore, the suitability of the recovery media should be tested after the cryopreservation step. Besides, some cryopreservation methods may impose more stress/damage than others. In our study, recovery percentages in control apices, not subjected to immersion in $\mathrm{LN}$, were significantly higher in droplet-vitrification than in the encapsulation-dehydration method, which only showed high recovery when the media employed did not have auxins ("Reed" medium). Similarly, less callus was produced during the recovery of cryopreserved (by controlled cooling) Rubus shoot tips when indol-3-butyric acid was not included in the recovery medium (Chang and Reed 1999). The effect of other types of growth regulators could be also considered. The combination of $\mathrm{GA}_{3}$ with cytokinins induced more vigorous plantlets from Anigozanthos viridis cryopreserved shoot apices than only the application of cytokinins (Turner et al. 2001). Furthermore, apex recovery after cryopreservation of a particular kiwi cultivar improved when auxin was removed and the appropriate balance between BAP and zeatin was employed (Bachiri et al. 2001). 
In the present work, we have found that the recovery medium does have an influence on the appropriate growth of cryopreserved mint apices, especially in the encapsulation-dehydration procedure where more damaged seem to be inflicted to the explants. With the appropriate medium, no differences were found between cultivars. Work is being carried out to study the possible influences of these factors on genetic stability after cryopreservation.

Acknowledgements: This research was supported by the Spanish Government Project AGL2010-21989-C02-01. C.K. is supported by a grant from Universidad Politécnica de Madrid.

\subsubsection{Bibliography}

Bachiri Y, Song GQ, Plessis P, Shoar-Ghaffari A, Rekab T, Morisset C (2001) Routine cryopreservation of kiwifruit (Actinidia spp) germplasm by encapsulation-dehydration: Importance of plant growth regulators. CryoLetters 22:61-74

Chang Y, Reed BM (1999) Extended cold acclimation and recovery medium alteration improve regrowth of Rubus shoot tips following cryopreservation. CryoLetters 20:371-376

Harding K (2004) Genetic integrity of cryopreserved plant cells: a review. CryoLetters $25: 3-22$

Martín C, Cervera MT, González-Benito ME (2011) Genetic stability analysis of chrysanthemum (Chrysanthemum ×morifolium Ramat) after different stages of an encapsulation-dehydration cryopreservation protocol. J Plant Physiol 168:158-66

Martín C, González-Benito ME (2005) Survival and genetic stability of Dendranthema grandiflora Tzvelev shoot apices after cryopreservation by vitrification and encapsulationdehydration. Cryobiology 51:281-289

Martín C, Senula A, González I, Acosta A, Keller E.R.J, González-Benito ME (2013) Genetic identity of three mint accessions stored by different conservation procedures: field collection, in vitro and cryopreservation. Genet Resour Crop Evol 60:243-249

Murashige T, Skoog F (1962) A revised medium for rapid growth and bio assays with tobacco tissue cultures. Physiol Plantarum 15:473-497 
Reed BM (2008) Cryopreservation: practical considerations. In: Reed BM (ed.) Plant Cryopreservation: a Practical Guide. Springer, p 3-13

Sakai A, Kobayashi S, Oiyama I (1990) Cryopreservation of nucellar cells of navel orange (Citrus sinensis Osb. var. brasiliensis Tanaka) by vitrification. Plant Cell Rep 9:30-33

Senula A, Keller ERJ, Sanduijay T, Yohannes T (2007) Cryopreservation of coldacclimated mint (Mentha spp.) shoot tips using a simple vitrification protocol. CryoLetters 28:1-12

Turner SR, Touchell DH, Senaratna T, Bunn E, Dixon KW (2001) Effects of plant growth regulators on survival and recovery growth following cryopreservation. CryoLetters 22:163174

Uchendu EE, Reed BM (2008) A comparative study of three cryopreservation protocols for effective storage of in vitro-grown mint (Mentha spp.). CryoLetters 29:181-188 


\subsection{Influence of the cryopreservation technique, recovery medium and genotype on genetic stability of mint cryopreserved shoot tips ${ }^{1}$}

\subsubsection{Abstract}

This study compared the effect of the cryoprerservation protocol, the genotype and the plant growth regulators used in the recovery media on the genetic stability of mint shoot tips. Shoot tips of two micropropagated genotypes of mint were cryopreserved either using an encapsulation-dehydration or droplet-vitrification protocol. Three recovery media were tested, all of them MS based although with different plant growth regulators: 1) $0.5 \mathrm{mgL}^{-1} 6$ benzylaminopurine (BAP); 2) $0.5 \mathrm{mgL}^{-1}$ 6-dimethylallylamino-purine $(2 \mathrm{iP})+0.1 \mathrm{mgL}^{-1} \alpha$ naphthalene acetic acid (NAA); and 3) $0.5 \mathrm{mg} \mathrm{L}^{-1} \mathrm{BAP}+0.1 \mathrm{mgL}^{-1} \mathrm{NAA}$. DNA was extracted from three different types of samples: leaves from shoots, callus at the base of shoots and callus. RAPD markers were used to assess the genetic stability. One of the genotypes, 'MEN 198', showed higher percentage of stable samples than the other one, 'MEN 186' (97\% vs $42 \%$; considering all media, protocol and type of explant). The material recovered after droplet-vitrification showed higher stability compared to the encapsulationdehydration recovered samples: $99 \%$ vs $87 \%$ in 'MEN 198', and $80 \%$ vs $24 \%$ in 'MEN 186'. There were not large differences in the genetic stability obtained from the three types of samples in 'MEN 198' (85-100\%), while in 'MEN 186' calli were more unstable (53\%, 44 $\%$ and $30 \%$ stability for leaves, basal callus and callus, respectively). The effect of the recovery medium on the stability of the samples was noticeable in the more unstable types of explants but not in leaves.

Keywords: apices, cryopreservation protocol, droplet-vitrification, encapsulationdehydration, genetic stability, Mentha $\times$ piperita L.

\subsubsection{Introduction}

Aromatic plants have experienced in the last years an increased attention and importance as crops due to their demand by consumers for culinary, medicinal and other applications. In

\footnotetext{
${ }^{1}$ This section reproduces the text of the manuscript: Martín, C, Kremer C, González-Benito ME, González I (2015) Plant Cell Tiss Organ Cult 122:185-195. COI 10.1007/s11240-015-0760-0.
} 
this context, search of wild genotypes, breeding programmes and genotype conservation are some of the tasks involved in the development of the production of these species (Lubbe and Verpoorte 2011).

One of the most reliable methods for long-term conservation is cryopreservation (conservation of living material at temperature below $-150{ }^{\circ} \mathrm{C}$ ), mainly due to its capability to guarantee the genetic stability of the preserved material during the process (Martín et al. 2013). However, the stresses suffered due to the treatments applied to avoid cell damage together with the in vitro culture, required for the recovery of the plant material, may affect the quality and quantity of the response after cryopreservation. Several steps of the cryopreservation protocols should be optimized before the application of these techniques to a given species (or even to a specific genotype). The aim is not only to obtain high survival after recovery but fully viable structures, i.e. shoot apices growing to form shoots without callus formation. This makes necessary to optimize the recovery conditions after removal from liquid nitrogen (or the vapour phase; $-150{ }^{\circ} \mathrm{C}$ ). Besides the environmental conditions (e.g. light conditions), the composition of the growth recovery medium is also important. In some species the removal of auxins led to a reduction of callus formation (Chang and Reed 1999). Complete success in cryopreservation process implies not only a high recovery rate after liquid nitrogen immersion, but also obtaining true-to-type plants. Therefore, the study of the genetic stability of cryopreserved material should also be considered (Harding 2004; Martín and González-Benito 2005; Martín et al. 2011).

During the last years, greater attention has been given to genetic stability studies of cryopreserved plant material. In vitro cultures of shoot tips are considered more stable than other types of cultures (e.g. callus). No genetic changes were detected by RAPD or AFLP markers after cryopreservation of in vitro shoot tips of Betula pendula Roth (Ryynanen 1998), Vitis and Actinidia (Zhai et al. 2003), Arachis (Gagliardi et al. 2003), Humulus (Peredo et al. 2008) and Prunus (Helliot et al. 2002). However, examples of detection of genetic instability can also be found. One line out of eight of Rabdosia rubescens shoot tips was found to be variable after cryopreservation by encapsulation-dehydration, amounting to a variance rate of $0.01 \%$ (Ai et al. 2012). In some cases genetic variation has been detected in control and cryopreservation-treated (without immersion in liquid nitrogen) individuals, which indicates that in vitro culture and the treatments applied (not the low temperature itself) could be responsible for such variability: this is the case of papaya shoot tips cryopreserved by vitrification (Kaity et al. 2013). On the other hand, genetic polymorphism was found in 
Rubus spp. shoots after a long period of in vitro culture and not in the cryopreserved shoots or in the field-grown plants derived from those shoots, indicating transitory genetic changes (Castillo et al. 2010). However, few studies have been carried out to reveal which procedures applied during cryopreservation could be related to those genetic changes. The pre-treatments applied to the plant material and the recovery medium, among other factors, could have independent or synergetic influences. When two cryopreservation protocols (encapsulationdehydration vs vitrification) were compared with chrysanthemum in vitro-grown shoot tips, higher genetic instability was detected after the first one (Martín and González-Benito 2005). Those changes appeared from the protocol step in which tips were precultured on medium with high sucrose concentration onwards (Martín et al. 2011).

During the development of cryopreservation protocols, it is important to obtain direct regrowth and to avoid callus formation (Engelmann 2011). Therefore, it is imperative to study the factors that could influence this response. The origin of the variations is usually attributed to the application of in vitro culture conditions during the process rather that to the very low temperatures (Keller et al. 2008). The fact that cryopreservation processes involve exposure to extreme physiological conditions should be taken into account. These include not only low temperature, but also dehydration stresses, together with the use of substances potentially toxic and/or mutagenic, such as dimethyl sulfoxide, DMSO (Ashwood-Smith 1985; Ipser 1992).

RAPD markers are quick and easy to perform. Other advantages of these markers are that small quantities of DNA are required and previous knowledge of DNA sequences is not necessary (Kumar et al. 2009). They have been previously used in genetic stability studies (for example, Aronen et al. 1999; Gagliardi et al. 2003; Martín and González-Benito 2005; Sánchez et al. 2008). A higher number of markers is usually detected with AFLP; however, both techniques have been demonstrated to be useful for detection of variation after cryopreservation and the latter one is much more expensive and time-consuming (Martín et al. 2011).

Mint (Mentha $\times$ piperita L.) is an infertile hybrid with vegetative propagation; this makes cryopreservation a very useful conservation technique, avoiding the risks related to field collections as well as time consumption and labour costs of in vitro conservation (Martín et al. 2013). Cryopreservation conditions must be controlled to guarantee an adequate regrowth rate and the quality of the recovered material. Several cryopreservation protocols have been 
developed and compared for mint: controlled cooling (Towill 1988; Uchendu and Reed 2008), vitrification (Towill 1990; Volk and Walters 2006; Uchendu and Reed 2008), encapsulationdehydration (Hirai and Sakai 1999; Sakai et al. 2000; Uchendu and Reed 2008), encapsulation-vitrification (Hirai and Sakai 1999; Sakai et al. 2000), droplet-vitrification (Senula et al. 2007), and vitrification cryo-plates (Yamamoto et al. 2012).

In order to develop appropriate cryopreservation protocols the possible influence of different factors on genetic stability should be studied. Therefore, we examined the influence of the recovery medium, cryopreservation technique and genotype on the stability of mint recovered biological material after cryopreservation. This paper presents a series of cryopreservation experiments after which DNA was extracted from different types of recovered plant material to study their RAPD profiles.

\subsubsection{Material and Methods}

\subsubsection{Plant Material and Preconditioning Treatments}

The work was carried out with two mint accessions (Mentha xpiperita L.) received from the genebank of IPK (Leibniz Institute of Plant Genetics and Crop Plant Research, Gatersleben, Germany), namely 'MEN 186' and 'MEN 198'. Shoots had been micropropagated by shoot culture for approximately 10 months in our laboratory by monthly subcultures on MS medium (Murashige and Skoog 1962), pH 5.7-5.8, with $3 \%$ sucrose, 0.7 $\%$ agar and no growth regulators, and incubated at $25{ }^{\circ} \mathrm{C}$, with a $16 \mathrm{~h}$ photoperiod and a Photosynthetic Photon Flux Density (PPFD) of $50 \mu \mathrm{mol} \mathrm{m} \mathrm{m}^{-2} \mathrm{~s}^{-1}$ from cool white fluorescent tubes.

Nodal segments were excised from the in vitro shoots and cultured on MS medium supplemented with $3 \%$ sucrose, and incubated for 3 weeks at $25{ }^{\circ} \mathrm{C}$ (light) $/-1{ }^{\circ} \mathrm{C}$ (dark) with a photoperiod of $16 \mathrm{~h}$ and $50 \mu \mathrm{mol} \mathrm{m} \mathrm{m}^{-2} \mathrm{~s}^{-1}$ PPFD. Subsequently, shoot tips (approx. $2 \mathrm{~mm}$ long, with 1-2 pairs of leaf primordia) were excised, transferred to liquid MS medium supplemented with $0.3 \mathrm{M}$ sucrose, and cultured at $25{ }^{\circ} \mathrm{C}$ for one day, with a PPFD of approximately $10 \mu \mathrm{mol} \mathrm{m} \mathrm{m}^{-2}$, with $16 \mathrm{~h}$ photoperiod. 


\subsubsection{Cryopreservation by Encapsulation-Dehydration}

Pre-conditioned shoot tips were immersed in a $3 \%$ sodium alginate solution prepared in MS liquid medium with 0.4 M sucrose. Drops of this solution, each one containing a shoot tip, were dispensed in liquid MS medium containing $100 \mathrm{mM} \mathrm{CaCl} 2$ and $0.4 \mathrm{M}$ sucrose. The formed beads were maintained in that solution for approximately half an hour. Subsequently, beads were cultured in MS liquid medium containing $0.75 \mathrm{M}$ sucrose, at $120 \mathrm{rpm}$, for $16-18 \mathrm{~h}$ (of which eight hours were in the dark and the rest under a PPFD of approximately $10 \mu \mathrm{mol}$ $\mathrm{m}^{-2} \mathrm{~s}^{-1}$ ). After that period, beads were removed, the excess of liquid dried from the surface with sterile filter paper, and placed on open Petri dishes to be dried for $5 \mathrm{~h}$ under the flow of a laminar-flow bench (to $22 \pm 1 \%$ water content fresh weight basis, Teixeira et al. 2014). Beads were then included in cryovials (five beads per cryovial) and rapidly immersed in liquid nitrogen (LN), and kept there for at least one day. Warming took place in a water bath at $40^{\circ} \mathrm{C}$, for approximately $2 \mathrm{~min}$. Beads were then cultured on the three recovery media tested. Beads containing shoot tips that had been subjected to all procedures except immersion in LN were used as the non-cryopreserved samples.

\subsubsection{Cryopreservation by Droplet-Vitrification}

A modified protocol of Senula et al. (2007) was used. Pre-conditioned apices were immersed in a loading solution (MS liquid medium $+2 \mathrm{M}$ glycerol $+0.4 \mathrm{M}$ sucrose), for 20 min at room temperature. After that, apices were maintained in the plant vitrification solution PVS2 (30 \% w/v glycerol, $15 \%$ w/v ethylene glycol and $15 \%$ w/v DMSO and $0.4 \mathrm{M}$ sucrose in liquid MS medium; Sakai et al. 1990) on ice (approx. $0{ }^{\circ} \mathrm{C}$ ) for $30 \mathrm{~min}$. Finally, shoot tips were placed into droplets $(2 \mu \mathrm{L})$ of PVS2 on aluminium foil strips (five explants per strip, each one in a droplet). These were included into cryovials (one strip per cryovial); the cryovials were closed and immersed in liquid nitrogen (LN), for at least one day. Warming was carried by placing the cryovials in a water bath at $40{ }^{\circ} \mathrm{C}$ for 20 seconds. Subsequently, 1 $\mathrm{mL}$ of rinsing solution (1.2 M sucrose in MS) was added to each cryotube. The tubes were slightly shaken, and the content was transferred into Petri dishes with $2 \mathrm{~mL}$ of rinsing solution and kept at room temperature for $20 \mathrm{~min}$. Shoot tips were then cultured on the three recovery media tested; those ones that had been subjected to all procedures except immersion in LN were used as the non-cryopreserved samples. 


\subsubsection{Recovery}

Beads/shoot tips from both cryopreservation protocols were cultured on MS semisolid medium supplemented with the following growth regulators: 1) $0.5 \mathrm{mgL}^{-1}$ 6benzylaminopurine (BAP; Uchendu and Reed 2008), 2) $0.5 \mathrm{mgL}^{-1}$ 6-dimethylallylaminopurine (2iP) + $0.1 \mathrm{mgL}^{-1} \alpha$-naphthalene acetic acid (NAA; Senula et al. 2007); and 3) $0.5 \mathrm{mgL}^{-}$ ${ }^{1} \mathrm{BAP}+0.1 \mathrm{mgL}^{-1} \mathrm{NAA}$. These media were named "Reed" (R), "Senula" (S) and "Nodes" $(\mathrm{N})$, respectively. In each experiment, 2-6 replicates for non-cryopreserved samples and 4-9 replicates for cryopreserved ones were used. A replicate was a $6 \mathrm{~cm}$ Petri dish $(10 \mathrm{~mL}$ medium) containing 5 beads or shoot tips. Cultures were incubated at $25{ }^{\circ} \mathrm{C}$, the first $24 \mathrm{~h}$ under darkness followed by 20 days with of approximately $10 \mu \mathrm{molm}^{-2} \mathrm{~s}^{-1}$ PPFD and then transferred to $50 \mu \mathrm{mol} \mathrm{m} \mathrm{m}^{-1}$, always with a $16 \mathrm{~h}$ photoperiod. For the experiments in which DNA isolation was carried out after an 8-week culture period, explants were transferred to culture jars with MS medium without growth regulators, after the first 4-week culture on the recovery media.

\subsubsection{RAPD Analysis}

Surviving explants after the two cryopreservation protocols (droplet-vitrification, "D", and encapsulation-dehydration, "E"), from both genotypes and the three different recovery media, were collected for DNA extraction, after 4- or 8-week recovery, depending on the experiment. Non-cryopreserved, i.e. treated as the cryopreserved shoot tips except for the immersion in LN (“0”), and cryopreserved (“+”) samples were included in the study, as well as portions of leaves from in vitro shoots (in vitro control samples). From the non-cryopreserved and cryopreserved explants, samples were obtained from leaves of shoots ("L") and the small basal callus that sometimes appeared ("cL"), and from explants that resulted only in callus growth after treatments (“C”; Fig. 4.4). They were stored at $-80^{\circ} \mathrm{C}$ until DNA isolation, which was carried out as described by Gawel and Jarret (1991) with minor modifications. DNA concentration was estimated by comparison with DNA standards in a $0.8 \%(\mathrm{w} / \mathrm{v})$ agarose gel. RAPD profiles were generated using eight arbitrary primers from Operon Technologies: OPA-11 (5' CAATCGCCGT 3'), OPE-19 (5' ACGGCGTATG 3'), OPF-1 (5' ACGGATCCTG 3'), OPF-3 (5' CCTGATCACC 3'), OPF-10 (5' GGAAGCTTGG 3'), OPO-7 (5' CAGCACTGAC 3'), OPO-10 (5' TCAGAGCGCC 3') and OPO-20 (5' ACACACGCTG $\left.3^{\prime}\right)$. DNA amplification reactions were performed in a volume of $25 \mu \mathrm{L}$ containing 
approximately $10 \mathrm{ng}$ total DNA, $0.4 \mu \mathrm{M}$ of a single decanucleotide, $0.2 \mathrm{mM}$ of each dNTP, $1.5 \mathrm{mM}$ of $\mathrm{MgCl}_{2}$ and $1 \mathrm{U}$ Taq DNA polymerase in the buffer provided by the enzyme manufacturer (Biotools). The PCR amplifications were performed in a DNA Thermal Cycler (Eppendorf) using one cycle of $1 \mathrm{~min}$ at $94{ }^{\circ} \mathrm{C}$, followed by 35 cycles of $45 \mathrm{~s}$ at $92{ }^{\circ} \mathrm{C}, 1 \mathrm{~min}$ at $37{ }^{\circ} \mathrm{C}$ and $2 \mathrm{~min}$ at $72{ }^{\circ} \mathrm{C}$, and a final cycle of $3 \mathrm{~min}$ at $72{ }^{\circ} \mathrm{C}$. Aliquots of $12 \mu \mathrm{L}$ of amplification products were loaded onto $1.5 \%$ (w/v) agarose gels for electrophoresis (carried out at $110 \mathrm{~V}$ ) using $1 \times$ TBE running buffer (Sambrook et al. 1989), followed by staining with ethidium bromide $(0.5 \mu \mathrm{g} / \mathrm{ml})$ for $7-10 \mathrm{~min}$ and photographed under UV light. The size of the amplified bands was related by reference to the molecular size marker (100 Base- Pair Ladder, GE Healthcare). All the amplifications were repeated at least twice, and only bands reproducible in several runs were considered for analysis.

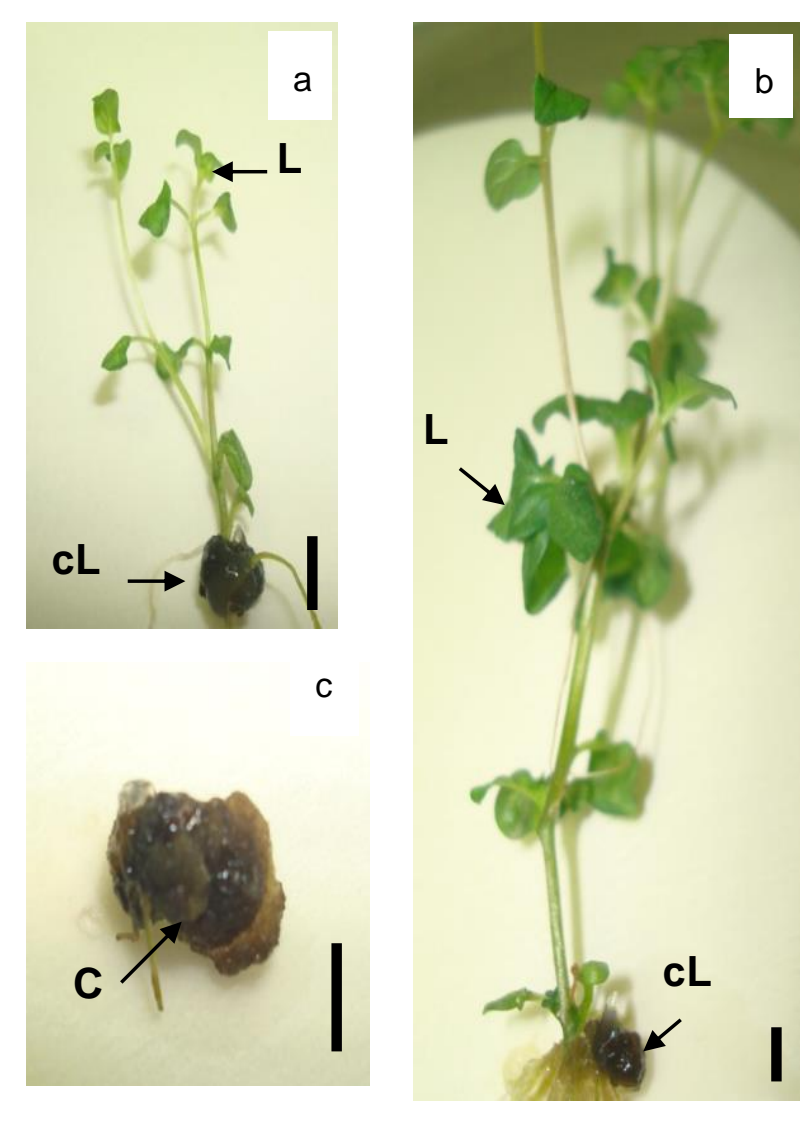

Figure 4.4. Types of samples from which DNA was obtained: "L", leaves from shoots; "cL" callus at the base of the shoots; "C" callus (samples from which no shoot recovery was obtained). Photographs from genotype 'MEN 198' after 4 weeks of culture (a and c) and after 8 weeks (b). Bars: approximately $5 \mathrm{~mm}$. 
The genetic stability of plant material obtained from both techniques (encapsulationdehydration and droplet-vitrification) and recovered on the three different media was analyzed in an experiment carried out with 'MEN 198'; 15 to 22 samples per combination of medium and technique were used, which represented between $22.4 \%$ and $68.7 \%$ of the survived explants. In a separate experiment, samples from 'MEN 186' were analysed after cryopreservation following both encapsulation-dehydration and droplet-vitrification techniques (18 and 20 samples, respectively; which represented between $28.6 \%$ and $55.5 \%$ of the survived explants) and recovered on "Reed" medium. In these two experiments, the plant material was collected after 4 weeks in culture

In order to further study the behaviour of shoot tips after the encapsulation-dehydration protocol, the genetic stability of samples recovered in all three media was studied in both genotypes after an 8-week culture period; 12 to16 samples per combination of genotype and medium were analysed (between $44.4 \%$ and $72.2 \%$ of the survived explants).

\subsubsection{Data Analysis}

Amplified fragments from the RAPD analyses of the pre-treated and cryopreserved samples as well as the in vitro plant were scored as present (1) or absent (0). Genetic similarities were calculated using the Jaccard similarity coefficient. The resultant matrix was subjected to cluster analysis by the unweighted pair-group method analysis (UPGMA) and a dendrogram was constructed from the clustering results with the TREE programme, using the package NTSYS-PC version 1.8 (Rohlf 1992).

\subsubsection{Results}

The eight primers used yielded between 70-73 scorable bands (depending on the experiment), ranging from 2,500 bp to $300 \mathrm{bp}$ (Fig. 4.5). From these results, one divergence in the presence or absence of a single amplified fragment represented a dissimilarity ranging from $1.3 \%$ to $4.6 \%$. 


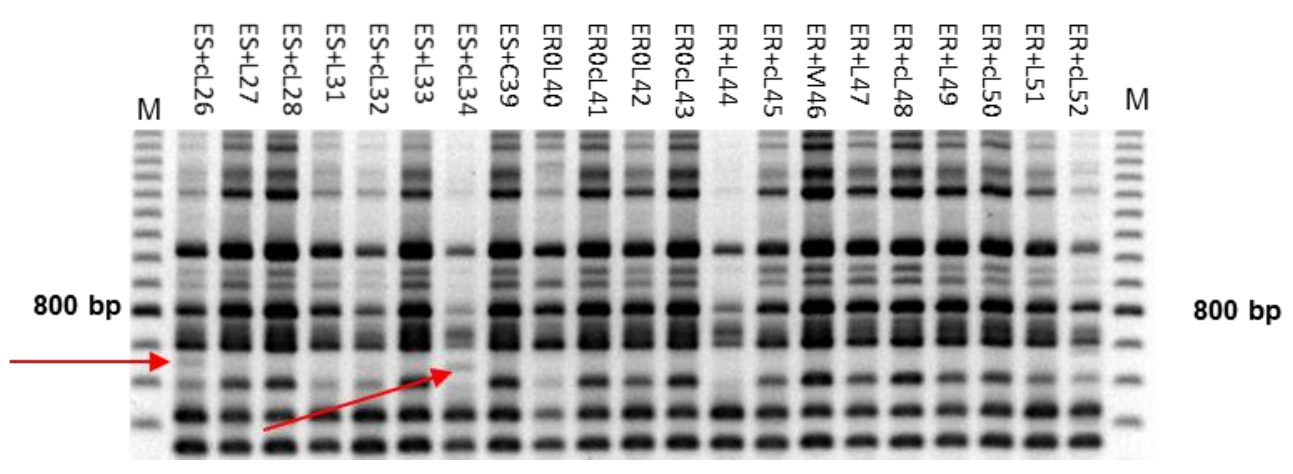

Figure 4.5. RAPD banding profiles of DNA samples from cryopreserved material using the encapsulation-dehydration protocol (E) of mint accession 'MEN 198' and regenerated on three different media. Amplification products were generated by primer OPO-7. M: 100 BasePair Ladder marker. Arrows show differences in the banding profile.

The analysis of the RAPD markers obtained from samples of genotype 'MEN 198' recovered after the two cryopreservation techniques on three different recovery media yielded 73 scorable markers for the 106 samples analysed (including the in vitro control). Fifty markers were monomorphic, being therefore $31.5 \%$ polymorphic. However, the differences affected only to 3 out of 106 samples studied (Fig. 4.6). These samples (DN0cL5, EN+cL9 and ES+cL51) corresponded to calli that were formed at the base of shoots (Fig. 4.4a); however, the level of their dissimilarity varied. Sample DNOcL5, obtained after the droplet protocol, presented a similarity value higher than $95 \%$ with the rest of the samples, while $\mathrm{EN}+\mathrm{cL} 9$ and ES+cL51, from the encapsulation-dehydration technique, presented a considerable lower value of similarity $(77 \%)$. These results revealed the high genetic stability of genotype 'MEN 198', not related to the technique used nor the media, although the only two samples clearly different corresponded to the encapsulation-dehydration protocol. All of the ten callus ("C") samples included were stable. The percentage of callus formation ("C" samples) observed in this experiment became strongly influenced by the culture medium, being "Reed" medium the one which resulted in a reduced callus formation. Higher callus formation in cryopreserved explants ("+") than in non-cryopreserved ("0") was also observed. (15\% vs $1.8 \%)$.

The two cryopreservation protocols were compared in genotype 'MEN 186' using "Reed" as recovery medium. Seventy reliable markers were analyzed for the 39 samples studied. In this genotype, a lower percentage of polymorphic markers was obtained $(15.7 \%)$ than in the 
case of 'MEN 198'. However, the number of different samples was higher than in the previous study with 'MEN 198': twenty showed a different pattern compared to the in vitro control, which represented $51 \%$ of the studied samples (Fig. 4.7). Another important difference was that the cryopreservation method seemed to have influenced the genetic stability. All the samples from the droplet-vitrification protocol, except two, clustered together with the in vitro sample, revealing a high genetic stability. Nevertheless, the only two samples out of this cluster had a similarity coefficient close to $98 \%$. These samples had been obtained after recovery from $\mathrm{LN}$ and were callus $(\mathrm{DR}+\mathrm{C} 11)$ or callus obtained from the base of shoot $(\mathrm{DR}+\mathrm{cL} 20)$. On the other hand, all the samples recovered from the encapsulationdehydration protocol showed some degree of variation compared to the in vitro material. Among them, all the specimens corresponding to leaves ("L") clustered together and showed a similarity degree with the in vitro sample higher than $95 \%$ (Fig. 4.7), whether they were derived from apices immersed into LN or not. However, all the samples from callus ("C") or basal callus (“cL") showed a similarity coefficient of $92 \%$.

A further analysis, considering only the encapsulation-dehydration protocol, was carried out with both genotypes. This time, samples were collected after 8 weeks of recovery. As it was observed before, genotype 'MEN 198' was very stable (Fig. 4.8). Seventy two scorable markers were obtained from the 42 samples analysed (including the in vitro sample), 61 markers were monomorphic, being therefore $15.3 \%$ polymorphic. Five different genotypes were detected; the one corresponding to the in vitro material included $71 \%$ of the samples, and a second genotype, with a percentage of similarity higher than $98 \%$, included $22 \%$ of the samples. Only two samples showed a percentage of similarity with the in vitro control lower than $95 \%$ (near $92 \%$ ), and both corresponded to basal callus samples ("cL") obtained after cryopreservation. No differences related to the recovery media were detected, as at the $98 \%$ similarity $94 \%, 92 \%$ and $100 \%$ of the samples were stable, for "Nodes", "Senula" and "Reed" media, respectively.

In this analysis after 8-week recovery, the more unstable behaviour of genotype 'MEN 186 ' was confirmed compared to 'MEN 198'. Only $55 \%$ of the samples were identical to the in vitro control (Fig. 4.9), and $24 \%$ showed a similarity coefficient below $95 \%$, being $85 \%$ the lowest value. Regarding the recovery media used during the first four weeks, and considering $98 \%$ similarity, $42 \%$ of the samples from "Nodes" medium were stable, while samples from "Senula" and "Reed" reached $71 \%$ and $67 \%$ stability, respectively. When the kind of tissue analysed was considered, some differences were detected. Seventy percent of 
leaf tissue samples ("L") were stable, while callus at the base of the shoots ("cL") and callus ("C") tissues samples presented a stability percentage of $41 \%$ and $50 \%$, respectively. However, considering the stability of leaf samples (as the recovered plant material that would be further maintained), no effect of the media could be detected being $60 \%$ in "Nodes", $71 \%$ in "Senula" and $67 \%$ in "Reed". On the other hand, the overall stability of "cL" and "C" samples varied with the recovery media: $29 \%, 71 \%$ and $67 \%$, respectively for "Nodes", "Senula" and "Reed". These results could be related to an interaction between media and type of explants. In this genotype ('MEN 186'), callus formation was again higher in those explants immersed in LN than in the non-cryopreserved. Likewise, a lower percentage of callus was observed in "Reed" medium (2\%) than in "Nodes" (10\%) and "Senula" (30\%) media. No effect of the immersion in liquid nitrogen was observed on stability, as $56 \%$ and $54 \%$ of the non-cryopreserved and cryopreserved samples, respectively, were similar to the in vitro plant material. 
Vitro, DNOL1, DNOcL2, ESOL70, ES0L68, ES0cL67, ES0L66, ES0C65, EN0cL64, ENOL63, EN0cL62, ENOL61, EN0cL60, EN0L59, ES+C58, ES+CL57, ES+L56, ES+cL54, ES+L53, ES+C52, DNOL3,

$E S+L 50, E S 0 L 49, E S 0 C 48, E S 0 c L 47, E S 0 L 46, E R+c L 41, E R+L 40, E R+c L 39, E R+L 38, E R+c L 37$,

$E R+L 36, E R+c L 35, E R+L 34, E R+L 32, E R+c L 31, E R 0 L 24, E R 0 c L 23, E R 0 L 22, E N+c L 21, E N+L 20$,

$E N+L 18, E N+L 16, E N+C L 15, E N+L 14, E N+C L 13, E N+L 12, E N+L 10$, DN0cL4, EN+L8, EN0cL4, EN0L2,

EN0L1, DS+C67, DS+cL66, DS+L65, DN+C64, DN+cL63, DN+L62, DR+C61, DR+L60, DR+cL59,

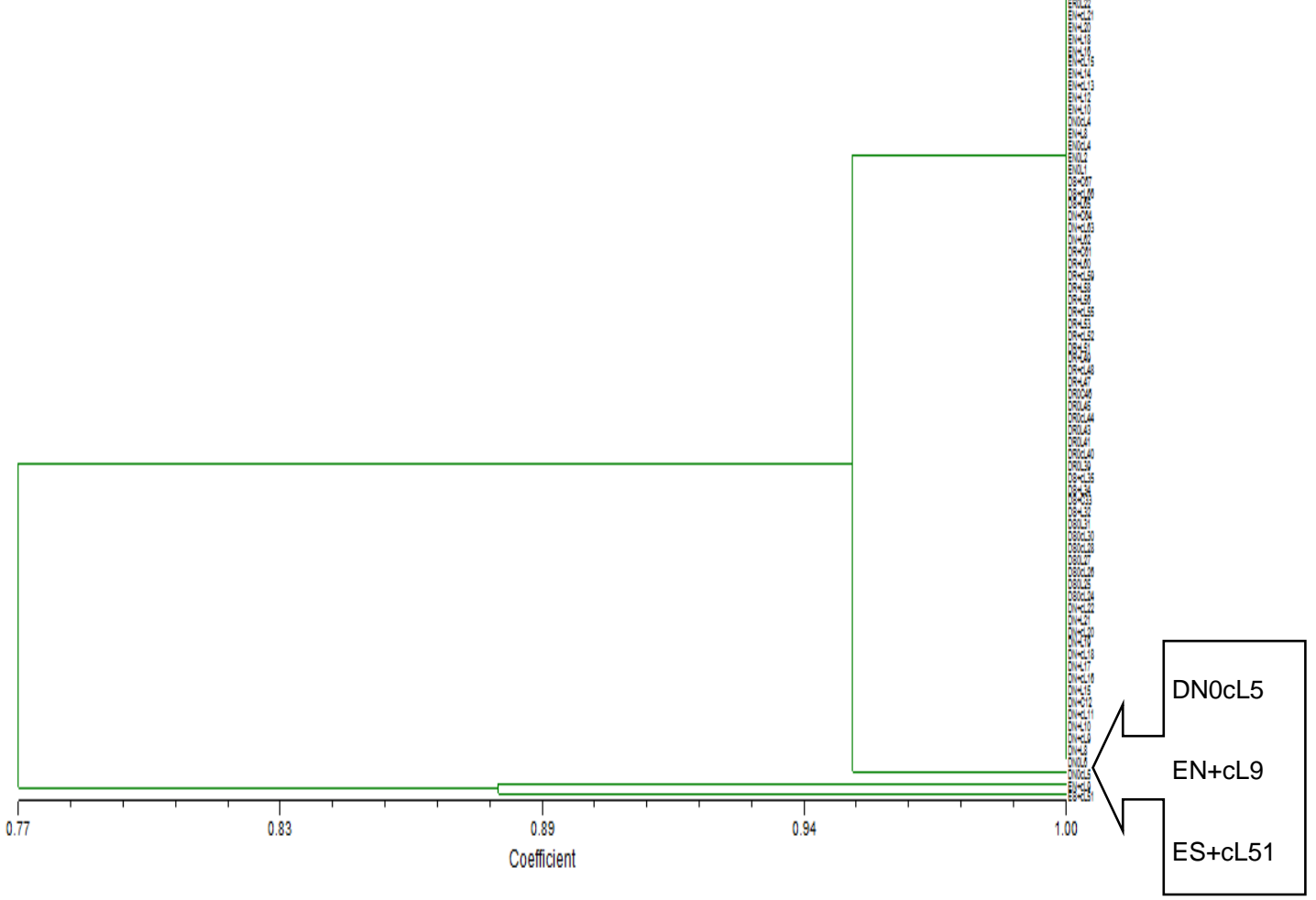

Figure 4.6. Dendrogram generated by the UPGMA method using Jaccard's similarity coefficient, based on RAPD markers of samples from mint plant material recovered 4 weeks after cryopreservation of accession 'MEN 198', using the encapsulation-dehydration technique (E) or droplet-vitrification (D). Samples were recovered on "Senula" (S), "Reed" $(\mathrm{R})$ or "Nodes" $(\mathrm{N})$ medium. Samples included those immersed in liquid nitrogen $(+)$, noncryopreserved ( 0 , i.e. treated similarly without immersion in liquid nitrogen) and in vitro cultures from which explants were obtained to perform the experiments (VITRO); the types of samples studied were: leaves ("L"), callus at the base of the shoots ("cL"), or callus ("C"). The last numbers indicate sample number. 


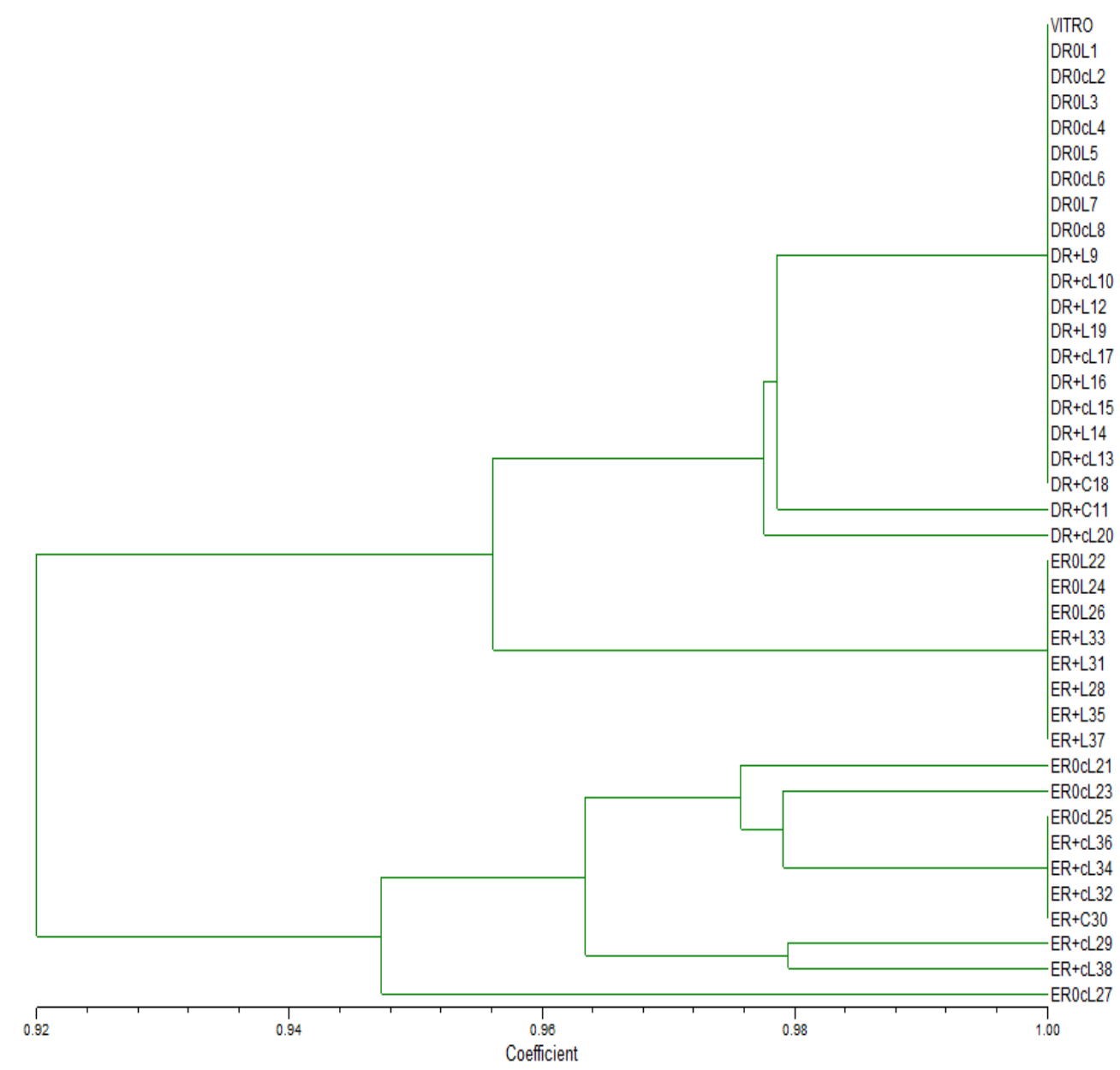

Figure 4.7. Dendrogram generated by the UPGMA method using Jaccard's similarity coefficient, based on RAPD markers of samples from mint plant material recovered 4 weeks after cryopreservation of accession 'MEN 186', using the encapsulation-dehydration technique (E) or droplet-vitrification (D). All samples were recovered on "Reed" medium (R). Samples included those immersed in liquid nitrogen $(+)$, non-cryopreserved $(0$, i.e. treated similarly without immersion in liquid nitrogen) and in vitro cultures from which apices were obtained to perform the experiments (VITRO); the types of samples studied were: leaves ("L"), callus at the base of the shoots ("cL"), or callus ("C"). The last numbers indicate sample number 


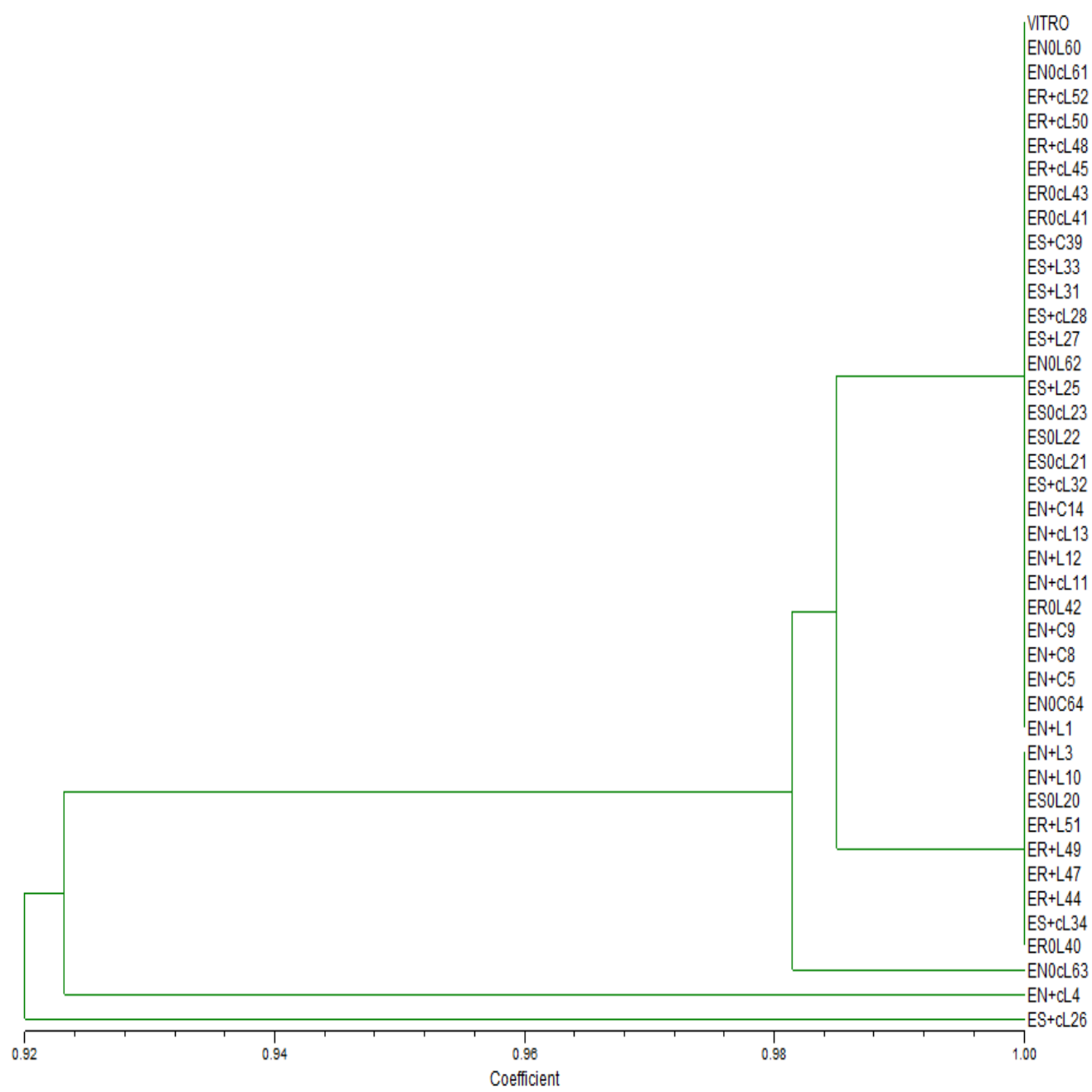

Figure 4.8. Dendrogram generated by the UPGMA method using Jaccard's similarity coefficient, based on RAPD markers of samples from mint plant material recovered 8 weeks after cryopreservation of accession 'MEN 198', using the encapsulation-dehydration technique (E). Samples were recovered on "Senula" (S), "Reed" medium (R) or "Nodes" (N) medium. Samples included those immersed in liquid nitrogen (+), non-cryopreserved (0, i.e. treated similarly without immersion in liquid nitrogen) and in vitro cultures from which apices were obtained to perform the experiments (VITRO); the types of samples studied were: leaves ("L"), callus at the base of the shoots ("cL"), or callus ("C"). The last numbers indicate sample number. 


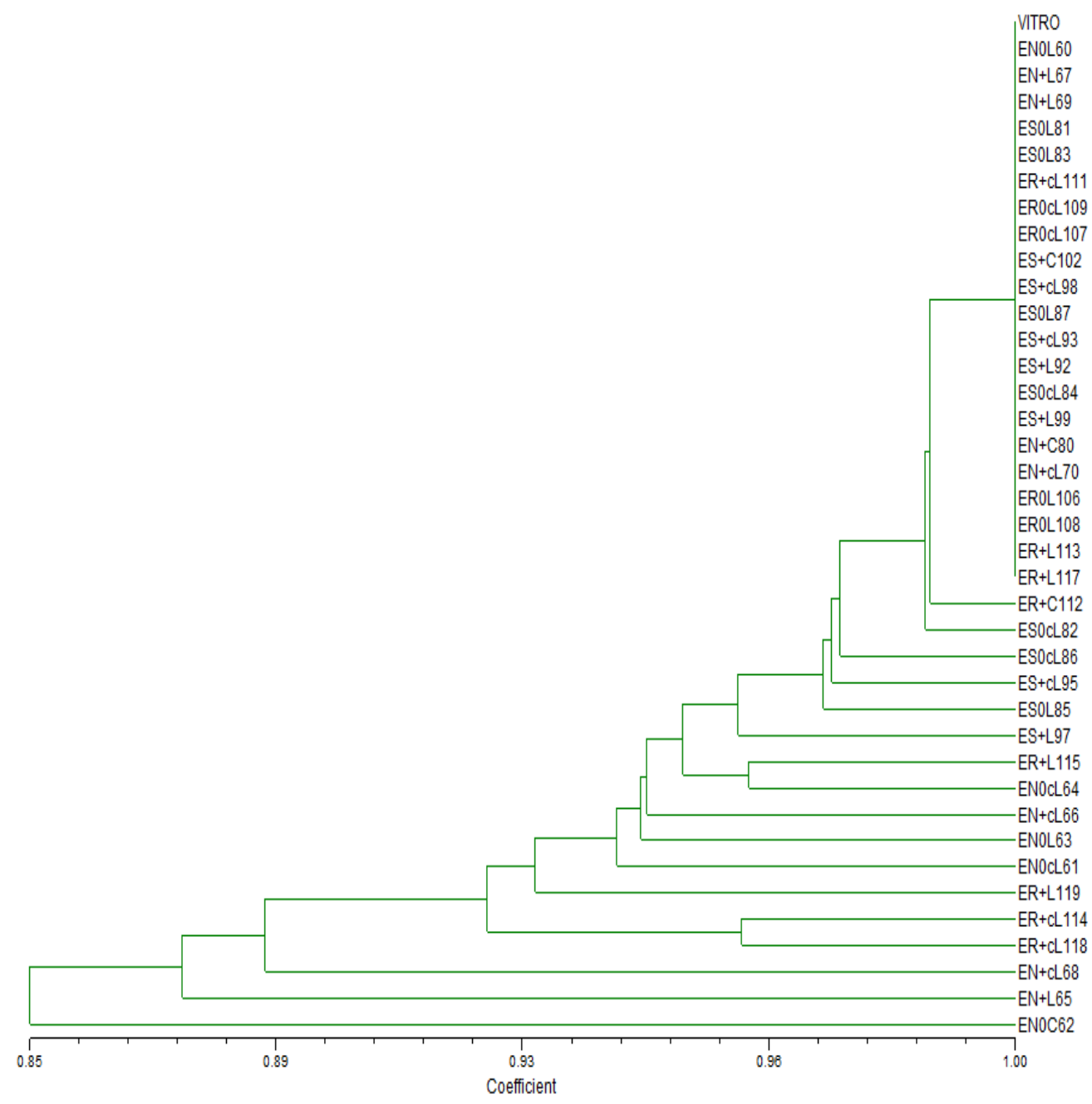

Figure 4.9. Dendrogram generated by the UPGMA method using Jaccard's similarity coefficient, based on RAPD markers of samples from mint plant material recovered 8 weeks after cryopreservation of accession MEN 186, using the encapsulation-dehydration technique (E). Samples were recovered on "Senula" (S), "Reed" medium (R) or "Nodes" $(\mathrm{N})$ medium. Samples included those immersed in liquid nitrogen $(+)$, non-cryopreserved $(0$, i.e. treated similarly without immersion in liquid nitrogen) and in vitro cultures from which apices were obtained to perform the experiments (VITRO); the types of samples studied were: leaves ("L"), callus at the base of the shoots ("cL"), or callus ("C"). The last numbers indicate sample number. 


\subsubsection{Discussion}

In the present study, the influence of recovery media and genotype have been compared in two cryopreservation protocols (encapsulation-dehydration and droplet-vitrification) in order to evaluate their effect on the genetic stability of the regenerated plants. Our results show a clear effect of the genotype and cryopreservation protocol on the genetic stability of the recovered samples. Genotype 'MEN 198' resulted more stable than 'MEN 186' and the encapsulation-dehydration protocol resulted in a higher number of unstable samples, which was more evident with the samples of 'MEN 186' (94\% vs $0 \%$ stable samples for dropletvitrification and encapsulation-dehydration, respectively).

The 'genotype' effect is well known in almost any tissue culture experiment. Different response of genotypes to the same treatment is a widespread result and force researchers to find the most convenient solution for each of them. Cryopreservation is not an exception, and in diverse works different results have been observed depending on the genotype (Reed 2001). For example, one out four Carica papaya genotypes of which shoot tips had been cryopreserved with a vitrification-based protocol showed a great level of variation, both in control and cryopreserved plants (Kaity et al. 2013).

This is not the first report on the negative effect of the encapsulation-dehydration protocol on the genetic stability of the cryopreserved material. Genetic instability in chrysanthemum regenerated plantlets was observed when encapsulation-dehydration was the shoot cryopreservation method used, but no variants were found after the vitrification protocol (Martín and González-Benito 2005). Similarly, Ai et al. (2012) used sequence-related amplified polymorphism (SRAP) markers to detect the DNA-level variation on shoots of Rabdosia rubescens recovered after an encapsulation-dehydration protocol and observed a variance rate of $0.01 \%$. Furthermore, different cryopreservation protocols can render, not only dissimilarities in the genetic stability of recovered specimens, but also differences in the recovery capability of the cryopreserved material. Matsumoto (2001) compared the effect of different cryopreservation protocols on wasabi (Eutrema japonicum Miq.) shoot-tips and detected a significant lower recovery with encapsulation-dehydration than with encapsulationvitrification or vitrification. The histological study of the regenerated material showed that nearly all of the cells remained viable in the vitrification protocols (combined or not with encapsulation), while massive structural damage was observed in the encapsulated-dehydrated meristems, except for the dome area. Similar results have been found comparing survival and 
recovery (shoot development) rates in cryopreservation of mint genotypes 'MEN 186' and 'MEN198' using the two types of protocols considered in this work (Kremer et al. in press).

Shoot regrowth after encapsulation-dehydration was lower than after droplet-vitrification in pretreated non-cryopreserved (no $\mathrm{LN}$ ) explants of both genotypes when recovery took place on "Nodes" or "Senula" media; however, on "Reed" medium recovery percentages were similar after both protocols, and higher than with the other two media. In cryopreserved apices, recovery was low $(<50 \%)$ in both methods, except when recovery was carried out on "Reed" medium; the effect of encapsulation-dehydration process seems to affect not only the genetic stability, but also the recovery. Matsumoto et al. (2013), working again with wasabi plants regenerated from long-term cryopreserved shoot tips, did not observed differences in the RAPD profiles of the cryopreserved material using a vitrification protocol; however, in this study, analyses of encapsulation-dehydration protocol were not included.

The negative effect of the encapsulation-dehydration protocol on stability is related to the treatments, as it can be observed both in pretreated and in cryopreserved (immersed in LN) samples. For example, in the encapsulation-dehydration experiments of genotype 'MEN 198', the genetic stability of non-cryopreserved and cryopreserved samples was $77 \%$ and $68 \%$, respectively. Similarly, the values observed in the more unstable genotype 'MEN 186' were $56 \%$ for the non-cryopreserved samples and $55 \%$ for cryopreserved ones. The main effect of the pre-treatment, rather than the ultra low temperature per se, could also be observed in a vitrification protocol in papaya since variants were found among vitrification-treated (not immersed in LN) plants (Kaity et al. 2013). The origin of the genetic instability in cryopreserved cultures, when it occurs, has been discussed (Harding 2004; Kulus and Zalewska 2014), and the effect of extreme low temperatures has been considered not the main source of variation. Our results in mint confirm this theory: the genetic instability appears during the pre-treatment in those protocols prone to instability, as encapsulation-dehydration seems to be (Martín et al. 2011).

In this work, not only the effect of the cryopreservation technique employed, but also the recovery media composition (i.e. plant growth regulators) has been taken into account to analyze the genetic stability of the mint samples. Previous studies by our group (Kremer et al. in press) have demonstrated that the use of growth medium without auxins (i.e. medium "Reed") produced higher recovery (shoot development) after cryopreservation than when auxins were included (i.e. "Nodes" and "Senula" media). Similarly, reduction of callus 
appearance and increased regrowth was observed after cryopreservation of quince nodal section by removing auxin from the recovery medium (Lynch et al. 2014). In the present work, in the more unstable genotype ('MEN 186') better stability results were observed in samples regenerated on "Senula" medium after cryopreservation (Senula $71.4 \%$ vs Nodes $57.1 \%$ and Reed $37.5 \%$ ). Considering both genotypes, and for the encapsulation-dehydration protocol, the samples that accumulated a higher quantity of variation corresponded to "Nodes" medium, mainly when the type of sample considered was callus (alone or at the base of the shoot). The highest callus formation was also found in this medium, and the increment of callus response was mainly observed in the explants immersed in LN (Kremer et al. in press). The effect of cryopreservation on callus formation was reported by $\mathrm{He}$ et al. (1998), who found that cryopreservation improved the rate of callus induction in Oryza meyeriana (Zoll \& Moritzi) Baill. In fact, most of the variable samples detected in this work corresponded to callus at the base of the shoots, though also some leaf samples showed instability. Although media composition is usually no taken into account, compared with other major factors such as the technique used, recovery medium is often important whether meristems or cell cultures are involved (Reed 1993).

The capability of the explants to recover into a well differentiated structure, without callus formation, has a very important role in the genetic stability of the resulted plant, and is directly affected by the medium composition. The dedifferentiation process in callus, followed by redifferentiation events when indirect shoots are developed, leads to frequent genetic modifications (Munthali et al. 1996, Al-Zahim et al. 1999, Salvi et al. 2001). Similarly, plants derived from calli of Oryza rufipogon cryopreserved by slow cooling showed 4.78-7.25\% change from control plants (seed-derived), when analysing molecular data generated using simple sequence repeat markers (SSR), suggesting that both callus induction and cryopreservation induced genetic variations (Zeliang et al. 2010). Although the correlation between callus formation and higher genetic stability is usually considered, the capability to regenerate genetically stable shoots from unstable calluses has been reported in chrysanthemum (Miñano et al. 2014). Analyzing different tissues from organogenic callus in chrysanthemum 'Red Reagan' the authors found that even when the original callus showed genetic variations, the shoots originated from it were stable, pointing to some kind of selective recovery from stable callus cells.

In conclusion, the success of a cryopreservation protocol depends of many factors which can affect differently to each genotype. Reducing as much as possible the effect of each of 
these factors in order to establish an universal protocol for each species would be desirable. However, different critical points can be found in each technique or genotype, although some common factors can be considered to offer a more suitable protocol. In our case, the use of droplet-vitrification protocol instead of encapsulation-dehydration seems to facilitate a more stable pathway for mint cryopreservation. Likewise, our results pointed to the pre-treatment factors as genetic variation source and not the LN immersion per se. Further studies on the effect of these pre-treatments would be necessary to understand the genetic instability process linked to encapsulation-dehydration protocols and to offer safer procedures. Likewise, phenotypical analyses of ex vitro plants obtained after cryopreservation using these protocols should be considered in the future to relate phenotype to the polymorphism revealed by the molecular markers.

Acknowledgements: This research was supported by the Spanish Government project AGL2010-21989-C02-01. C.K. is supported by a grant from Universidad Politécnica de Madrid. Technical support from C. Sansegundo, M. Huertas and C. Ruiz is appreciated.

\subsubsection{Bibliography}

Ai PF, Lu LP, Song JJ (2012) Cryopreservation of in vitro-grown shoot-tips of Rabdosia rubescens by encapsulation-dehydration and evaluation of their genetic stability. Plant Cell Tiss Organ Cult 108:381-387

Al-Zahim MA, Ford-Lloyd BV, Newbury HJ (1999) Detection of somaclonal variation in garlic (Allium sativum L.) using RAPD and cytological analysis. Plant Cell Rep 18:473-477

Aronen TS, Krajnakova J, Häggman HM, Ryynänen LA (1999) Genetic fidelity of cryopreserved embryogenic cultures of open-pollinated Abies cephalonica. Plant Sci 142:16372

Ashwood-Smith MJ (1985) Genetic damage is not produced by normal cryopreservation procedures involving either glycerol or dimethyl sulfoxide: a cautionary note, however, on possible effects of dimethyl sulfoxide. Cryobiology 22:427-433

Castillo NRF, Bassil NV, Wada S, Reed BM (2010) Genetic stability of cryopreserved shoot tips of Rubus germplasm. In Vitro Cell Dev Biol-Plant 46:246-256 
Chang YJ, Reed BM (1999) Extended cold acclimation and recovery medium alteration improve regrowth of Rubus shoot tips following cryopreservation. CryoLetters 20:371-376

Engelmann F (2011) Use of biotechnologies for the conservation of plant biodiversity. In Vitro Cell Dev Biol-Plant 47:5-16

Gagliardi R, Pacheco G, Carneiro L, Valls J, Vieira M, Mansur E (2003) Cryopreservation of Arachis species by vitrification of in vitro grown shoot apices and genetic stability of recovered plants. CryoLetters 24:103-110

Gawel NJ, Jarret RL (1991) A modified CTAB DNA extraction procedure of Musa and Ipomoea. Plant Mol Biol Rep 9: 262-266

Harding K (2004) Genetic integrity of cryopreserved plant cells: a review. CryoLetters $25: 3-22$

He G, Shu L, Liao L, Yin X, Sheng L, Wang X (1998) Somatic cell preservation and protoplast regeneration of important disease resistant wild rice Oryza meyeriana Baill. Sci China 41:393-399

Helliot B, Madur D, Dirlewanger E, De Boucaud MT (2002) Evaluation of genetic stability in cryopreserved Prunus. In Vitro Cell Dev Biol-Plant 38:493-500

Hirai D, Sakai A (1999) Cryopreservation of in vitro-grown axillary shoot-tip meristems of mint (Mentha spicata L.) by encapsulation-vitrification. Plant Cell Rep 19:150-155

Ipser J (1992) Effect of dimethylsulfoxide on methylmethanesulfonate induced chromosomal aberrations in Crepis capillaris cultivated in vitro. Biol Plant 35:137-139

Kaity A, Drew RA, Ashmore SE (2013) Genetic and epigenetic integrity assessment of acclimatized papaya plants regenerated directly from shoot-tips following short- and longterm cryopreservation. Plant Cell Tiss Organ Cult 112:75-86

Keller ERJ, Senula A, Kacznarczyk A (2008) Cryopreservation of herbaceous dicots. In: Reed BM (ed) Plant cryopreservation: a practical guide. Springer Science-Business Media LLC, NewYork, pp 281-332 
Kremer C, Martín C, González I, González-Benito ME (in press) Regeneration in mint (Mentha xpiperita L.) cryopreserved apices: can the cryopreservation technique, recovery medium and genotype affect the final results? Acta Horticulturae

Kulus D, Zalewska M (2014) Cryopreservation as a tool used in long-term storage of ornamental species - A review. Scientia Horticulturae 168:88-107

Kumar P, Gupta VK, Misra AK, Modi DR, Pandey BK (2009) Potential of molecular markers in plant biotechnology. Plant Omics 2:141-162

Lubbe A, Verpoorte R (2011) Cultivation of medicinal and aromatic plants for specialty industrial materials. Ind Crop Prod 34:785-801

Lynch PT, Siddika A, Mehra A, Benelli C, Lambardi M (2014) Cryopreservation of quince (Cydonia oblonga Mill.). CryoLetters 35:188-196

Martín C, Cervera MT, González-Benito ME (2011) Genetic stability analysis of chrysanthemum (Chrysanthemum $\times$ morifolium Ramat) after different stages of an encapsulation-dehydration cryopreservation protocol. J Plant Physiol 168:158-66

Martín C, González-Benito ME (2005) Survival and genetic stability of Dendranthema grandiflora Tzvelev shoot apices after cryopreservation by vitrification and encapsulationdehydration. Cryobiology 51:281-289

Martín C, Senula A, González I, Acosta A, Keller E.R.J, González-Benito ME (2013) Genetic identity of three mint accessions stored by different conservation procedures: field collection, in vitro and cryopreservation. Genet Resour Crop Evol 60:243-249

Matsumoto T (2001) Cryopreservation of in vitro-cultured meristems of wasabi. In Engelmann F, Takagi H (eds.) Cryopreservation of Tropical Plant Germplasm - current research progress and applications. JIRCAS/IPGRI, Tsukuba (Japan)/Rome (Italy), pp 212216

Matsumoto T, Akihiro T, Maki S, Mochida K, Kitagawa M, Tanaka D, Yamamoto S-I, Niino T (2013) Genetic stability assessment of wasabi plants regenerated from long-term cryopreserved shoot tips using morphological, biochemical and molecular analysis. CryoLetters 34:128-36 
Miñano HS, Ibáñez MA, González-Benito ME, Martín C (2014) Sequential study of the genetic stability of callus and regenerated shoots in chrysanthemum. Propag Ornam Plants 14:57-67

Munthali MT, Newbury HJ, Ford-Lloyd BV (1996) The detection of somaclonal variants of beet using RAPD. Plant Cell Rep 15:474- 478

Murashige T, Skoog F (1962) A revised medium for rapid growth and bio assays with tobacco tissue cultures. Physiol Plantarum 15:473-497

Peredo EL, Arroyo-García R, Reed BM, Revilla MA (2008) Genetic and epigenetic stability of cryopreserved and cold-stored hops (Humulus lupulus L.). Cryobiology 57: 234241

Reed BM (1993) Responses to ABA and cold acclimation are genotype dependent for cryopreserved blackberry and raspberry meristems. Cryobiology 30:179-184

Reed BM (2001) Genotype considerations in temperate fruit crop cryopreservation. In Engelmann F, Takagi H (eds.) Cryopreservation of Tropical Plant Germplasm - current research progress and applications. JIRCAS/IPGRI, Tsukuba (Japan)/Rome (Italy), pp 200205

Rohlf FJ (1992) NTSYS-PC: numerical taxonomy and multivariate analysis system. Exeter Software, New York

Ryynanen L (1998) Effect of abscisic acid, cold hardening, and photoperiod on recovery of cryopreserved in vitro shoot tips of silver birch. Cryobiology 36:32-39

Sambrook J, Fritsch EF, Maniatis T (1989) Molecular cloning: a laboratory manual. Cold Spring Harbor Laboratory Press, 2nd ed., New York

Sakai A, Kobayashi S, Oiyama I (1990) Cryopreservation of nucellar cells of navel orange (Citrussinensis Osb. var. brasiliensis Tanaka) by vitrification. Plant Cell Rep 9:30-33

Sakai A, Matsumoto T, Hirai D, Niino T (2000) Newly development encapsulationdehydration protocol for plant cryopreservation. CryoLetters 21:53-62 
Salvi ND, George L, Eapen S (2001) Plant regeneration from leaf base callus of turmeric and random amplified polymorphic DNA analysis of regenerated plants. Plant Cell Tiss Organ Cult 66:113- 119

Sánchez C, Martinez MT, Vidal N, San-Jose MC, Valladares S, Vieitez AM (2008) Preservation of Quercus robur germplasm by cryostorage of embryogenic cultures derived from mature trees and RAPD analysis of genetic stability. CryoLetters 29:493-504

Senula A, Keller J, Sanduijav T, Yohannes T (2007) Cryopreservation of cold-acclimated mint (Mentha spp.) shoot tips using a simple vitrification protocol. CryoLetters 28:1-12

Teixeira AS, González-Benito ME, Molina-García AD (2014) Determination of glassy state by cryo-SEM and DSC in cryopreservation of mint shoot tips by encapsulationdehydration. Plant Cell Tiss Organ Cult 119:269-280

Towill LE (1988) Survival of shoot tips from mint species after short-term exposure to cryogenic conditions. Hort Science 23:839-841

Towill LE (1990) Cryopreservation of isolated mint shoot tips by vitrification. Plant Cell Rep 9:178-180

Uchendu EE, Reed B (2008) A comparative study of three cryopreservation protocols for effective storage of in vitro grown mint (Mentha spp.). CryoLetters 29:181-188

Volk GM, Walters C (2006) Plant vitrification solution 2 lowers water content and alters freezing behavior in shoot tips during cryoprotection. Cryobiology 52:48-61

Yamamoto S, Rafique T, Fukui K, Sekizawa K, Niino T (2012) V-cryo-plate procedure as an effective protocol forcryobanks: case study of mint cryopreservation. CryoLetters 33:12-23

Zeliang PK, Pattanayak A, Iangrai B, Khongwir EA, Sarma BK (2010) Fertile plant regeneration from cryopreserved calli of Oryza rufipogon Griff. and assessment of variation in the progeny of regenerated plants. Plant Cell Rep 29:1423-1433

Zhai Z, Wu Y, Engelmann F, Chen R, Zhao Y (2003) Genetic stability assessments of plantlets regenerated from cryopreserved in vitro cultured grape and kiwi shoot tips using RAPD. CryoLetters 24:315-322 


\section{EFFECT OF ANTIOXIDANTS ON THE GENETIC STABILITY OF CRYOPRESERVED MINT SHOOT TIPS BY ENCAPSULATION-DEHYDRATION ${ }^{1}$}

\subsection{Abstract}

The effect of antioxidants applied in one step of a cryopreservation protocol by encapsulation-dehydration on recovery and genetic stability of mint shoot tips has been studied. Glutathione $(0.16 \mathrm{mM}$ or $0.24 \mathrm{mM})$, ascorbic acid $(0.28 \mathrm{mM}$ or $0.43 \mathrm{mM})$ and $\alpha$-tocopherol (vitamin E) were added to the preculture medium (0.3 M sucrose). DNA was extracted from three different types of samples: leaves from shoots, callus at the base of shoots and callus. RAPD and AFLP markers were used to assess the genetic stability. The use of antioxidants did not improve recovery after cryopreservation. One of the genotypes, 'MEN 198', showed higher percentage of stable samples than the other one, 'MEN 186' (56\% vs $37 \%$; considering treatments and type of explant). The use of vitamin E improved the percentage of stable samples with respect to control treatment (no antioxidant) in 'MEN 186'. No differences in the percentages of stable samples were observed among cryopreserved and non-cryopreserved (treated similarly without immersion in liquid nitrogen) plant material. Recovered shoots of both genotypes showed higher stability (76-80\% stable samples) than callus samples (14-22\%).

Keywords: antioxidants, cryopreservation, genetic stability, recovery

\footnotetext{
${ }^{1}$ This section reproduces the text of the manuscript: González-Benito ME, Kremer C, Ibañez MA, Martín C. Submitted to Plant Cell, Tissue and Organ Culture
} 


\subsection{Introduction}

Cryopreservation (conservation of living material at temperature below $-150{ }^{\circ} \mathrm{C}$, usually in liquid nitrogen, LN), has been applied to several plant species and types of plant material. Cryopreservation is a reliable method for long-term storage of plant germplasm and biotechnological plant material (e.g. cell cultures). Several cryopreservation protocols based on the vitrification of both intra- and extracellular solutions have been developed since the 1990's (Sakai 2004). Encapsulation-dehydration is one possible procedure. It is based on the synthetic seed technology and vitrification is achieved after dehydration and fast cooling (Dereuddre et al. 1990). One advantage of this technique, compared to other possible ones to cryopreserve plant material, is that plant material handling inside the alginate bead is usually easier, and it is a simple technique to implement. This technique has been applied to several species and genotypes (Engelmann et al. 2008).

The poor response to cryopreservation of some species or genotypes has been related, in some cases, to oxidative damage (Johnston et al. 2007). Several of the treatments applied to plant tissues prior immersion in liquid nitrogen to avoid ice crystal formation impose cellular stress that result in excessive Reactive Oxygen Species (ROS) formation. ROS are formed during cellular metabolic reactions as byproducts of redox reactions, but also play a role in cell signaling, immunity and apoptosis (Kovalchuk 2011). Exposure to stresses, both biotic and abiotic, increases the levels of free radicals in cells. Oxidative damage has been found in several steps of cryopreservation protocols, as early as explant excision (Whitaker et al. 2010). Osmotic pretreatments can also impose oxidative stress, as shown with olive somatic embryos treated with sorbitol (Lynch et al. 2011). In addition, partial dehydration and cooling increased oxidative damage in zygotic embryos of recalcitrant seeds (Sershen et al. 2012). When the response after cryopreservation by encapsulation-dehydration of two Ribes species was compared, the species that showed higher recovery after cryopreservation displayed higher antioxidant activity (Johnston et al. 2007). Furthermore, differential response to cryopreservation (by vitrification with PVS2) of Arabidopsis thaliana 48- and $72 \mathrm{~h}$-seedlings (the latter being more sensitive) was related to the expression of oxidative stress response genes (Ren et al. 2013). However, ROS, at low concentrations, regulate cellular functions and act as signaling molecules and, in this line, an increased ROS generation was found to be related to improved viability after cryopreservation of Lilium $\times$ siberia pollen $(\mathrm{Xu}$ et al. 2014). 
Many antioxidants have proved to be effective increasing regrowth after cryopreservation in several species (Reed 2014). Survival of citrus shoot tips after cryopreservation by vitrification was enhanced by the use of glutathione (GSH) in the preculture medium (containing glycerol and high sucrose concentration), in the loading and the vitrification solutions, and in the recovery medium (Wang and Deng 2004). Similarly, supplementation of both preculture and regrowth media with melatonin $(0.1-0.5 \mu \mathrm{M})$ improved regrowth of shoot tips of American elm, St John's Wort and tobacco after cryopreservation by vitrification with PVS2 (Uchendu et al. 2013, 2014). When $0.28 \mathrm{mM}$ ascorbic acid was added to several steps of the vitrification protocol, higher survival was observed in shoot tips of Nephelium ramboutan-ake not subjected to $\mathrm{LN}$ exposure than without the addition of the antioxidant. Furthermore, survival after exposure to LN took place only with the addition of ascorbic acid during the loading step (Chua and Normah 2011). Uchendu et al. (2010a) compared the use of Vitamin E and ascorbic acid, at several concentrations, in four steps (pretreatment, loading, rinsing, regrowth) of a vitrification protocol for the cryopreservation of shoot tips of two blackberry cultivars. Both substances improved regrowth after cryopreservation when applied in any of the steps tested; nevertheless ascorbic acid was more effective and at a wider range of concentrations $(0.16-0.58 \mathrm{mM})$.

Antioxidants are part of the mechanism that controls the accumulation of ROS in plants, to lessen their cytotoxic and reactive properties (Bhattacharjee 2011). Ascorbic acid is present in chloroplast, cytosol, vacuoles and apoplast; it is a direct scavenger of $\mathrm{O}_{2}{ }^{--}$and has an essential role removing $\mathrm{H}_{2} \mathrm{O}_{2}$ through the Halliwell-Asada pathway. $\mathrm{H}_{2} \mathrm{O}_{2}$ is also removed thorough the ascorbate/glutathione cycle (Alscher and Hess 1993). Glutathione prevents lipid peroxidation and, by the oxidation of its thiol group, avoids the oxidation of the thiol group of enzymes. Vitamin E refers to a group of compounds that include both tocopherols and tocotrienols; $\alpha$-tocopherol is a lipophilic antioxidant that protects membranes against lipid peroxidation and a scavenger of ${ }^{1} \mathrm{O}_{2}, \mathrm{OH} \bullet$ and $\mathrm{O}_{2}{ }^{\bullet-}$ (Bhattacharjee 2011).

ROS are highly reactive and can disturb the normal cellular activity through oxidative damage to membrane lipids, proteins and nucleic acids (Imlay 2003; Bhattacharjee 2011). DNA damage is produced mainly by $\mathrm{OH} \bullet$, and ${ }^{1} \mathrm{O}_{2}: \mathrm{OH} \bullet$ is the most damaging as affects purine and pyrimidine bases as well as deoxyribose; ${ }^{1} \mathrm{O}_{2}$ attacks guanine (Gill et al. 2010). The damages produced include deletions, mutations, base modifications and strand breaks. Besides, $\mathrm{O}_{2}{ }^{--}$has been reported to induce lipid peroxidation, inactivation of enzymes and changes in DNA, causing mutations in plants (Arora et al. 2002). 
Therefore, we hypothesize that antioxidants could play a role not only improving the recovery after cryopreservation, but also reducing genetic instability. A previous study from our group, in which the genetic instability of chrysanthemum shoot tips originated from several steps of a cryopreservation protocol was assessed, found an increased frequency of DNA variation after the high concentration (0.3 M) sucrose pre-treatment (Martín et al. 2011). Consequently, the aim of this work was to study the effect of several antioxidants on recovery and genetic stability of shoot tips of two mint genotypes after cryopreservation by encapsulation-dehydration. The antioxidants were applied during the step of the protocol where osmotic stress was firstly applied to plant material (culture on 0.3 M sucrose).

\subsection{Materials and Method}

\subsubsection{Plant material and Preconditioning Treatments}

In vitro plants of two clones of Mentha x piperita L. ('MEN 186' and 'MEN 198') received from the genebank of IPK (Leibniz Institute of Plant Genetics and Crop Plant Research, Gatersleben, Germany) were used. They were micropropagated by monthly subculture of shoots on a MS medium (Murashige and Skoog 1962) supplemented with $3 \%$ sucrose and $0.7 \%$ agar and incubated at $25{ }^{\circ} \mathrm{C}$, with a $16 \mathrm{~h}$ photoperiod and a Photosynthetic Photon Flux Density (PPFD) of $50 \mu \mathrm{mol} \mathrm{m} \mathrm{m}^{-2}$ from cool white fluorescent tubes.

Nodal segments (approximately $1 \mathrm{~cm}$ long) were excised, cultured on MS medium and incubated for 3 weeks at $25{ }^{\circ} \mathrm{C}$ (light)/-1 ${ }^{\circ} \mathrm{C}$ (dark) with a photoperiod of $16 \mathrm{~h}$ and $50 \mu \mathrm{mol}$ $\mathrm{m}^{-2} \mathrm{~s}^{-1}$ PPFD. Subsequently, shoot tips (approx. $2 \mathrm{~mm}$ long, with 1-2 pairs of leaf primordia) developed from axillary buds of nodal segments were excised under dissecting microscope and cultured on liquid MS medium supplemented with $0.3 \mathrm{M}$ sucrose, on top of two filter paper disks. Different antioxidants were used in this step of the protocol: $0.16 \mathrm{mM}$ or 0.24 $\mathrm{mM}$ glutathione, $0.28 \mathrm{mM}$ or $0.43 \mathrm{mM}$ ascorbic acid, all of them added to the medium; or $\alpha$-tocopherol (Vitamin E) spread on filter paper and placed on the liquid medium. Shoot tips cultured on $0.3 \mathrm{M}$ sucrose without any antioxidant were considered the control treatment. In all cases, tips were incubated at $25{ }^{\circ} \mathrm{C}$ for one day, with a PPFD of approximately $10 \mu \mathrm{mol}$ $\mathrm{m}^{-2} \mathrm{~s}^{-1}$, with $16 \mathrm{~h}$ photoperiod. 


\subsubsection{Cryopreservation}

Pre-treated tips were immersed in alginate solution (liquid MS $+0.35 \mathrm{M}$ sucrose $+3 \%$ sodium alginate medium viscosity). Drops of this solution, each one containing a shoot tip, were dispensed in MS liquid medium containing $100 \mathrm{mM} \mathrm{CaCl} 2$ and $0.35 \mathrm{M}$ sucrose, and maintained for $30 \mathrm{~min}$ in that solution. Subsequently, the already formed beads were cultured in MS liquid medium supplemented with $0.75 \mathrm{M}$ sucrose, shaking at $120 \mathrm{rpm}$, for $18-20$ hours. After this period, the beads were removed from the medium, blotted on sterile filter paper and placed on open Petri dishes to be dried for $5 \mathrm{~h}$ under the flow of a laminar-flow bench (to $22 \pm 1 \%$ water content fresh weight basis, Teixeira et al. 2014). Once dried, five beads were placed in a cryovial and immersed for one day in liquid nitrogen (LN). Subsequently, the cryovials were reheated in a sterile water bath at $40{ }^{\circ} \mathrm{C}$ for $2 \mathrm{~min}$ and, afterwards, the beads were cultured in $6 \mathrm{~cm}$ diameter Petri dishes ( 5 beads per Petri dish) containing recovery medium $\left(\mathrm{MS}+0.5 \mathrm{mgL}^{-1}\right.$ 6-dimethylallylamino-purine $(2-\mathrm{iP})+0.1$ $\operatorname{mgL}^{-1} \alpha$-naphthalene acetic acid (NAA) $+3 \%$ sucrose $+0.7 \%$ agar; Senula et al. 2007) Cultures were incubated at $25^{\circ} \mathrm{C}$, the first $24 \mathrm{~h}$ under darkness followed by 20 days with of approximately $10 \mu \mathrm{mol} \mathrm{m} \mathrm{m}^{-2} \mathrm{PPFD}$ and then transferred to $50 \mu \mathrm{mol} \mathrm{m} \mathrm{m}^{-2} \mathrm{~s}^{-1}$, always with a 16 $\mathrm{h}$ photoperiod. Four weeks after recovery, all surviving plant material from one Petri dish was transferred to a culture jar with MS medium and cultured for further four weeks. After this time, data on survival and shoot recovery were registered. In genotype 'MEN 186' both noncryopreserved (subjected to all treatments except immersion in LN) and cryopreserved shoot tips were studied, while only cryopreserved tips were studied in 'MEN 198'.

\subsubsection{Sampling and DNA isolation}

From each treatment, different types of plant material were used for DNA extraction after the 8-week recovery period: shoots regenerated from tips ("L"), callus that appeared at the base of shoots ("cL"), and explants that resulted only in callus growth after treatments ("C"). DNA was also extracted from 5 shoots from which nodal segments were excised to start the experiment and pooled to include them in the analysis as a control ("VITRO" samples in the dendrograms). The samples were stored at $-80{ }^{\circ} \mathrm{C}$ until DNA isolation. Genomic DNA was extracted from frozen tissue, according to Gawel and Jarret procedure (1991). 
Seven to 11 samples were analyzed per antioxidant treatment for RAPD analysis, and 3 or 5 samples for AFLP's (see Table 5.1).

\subsubsection{RAPD analysis}

Eight primers from Operon Technologies Inc. (Alameda/CA, USA) were used for RAPD`s analysis: OPA-11 (5' CAATCGCCGT 3'), OPE-19 (5' ACGGCGTATG 3'), OPF-1 (5' ACGGATCCTG 3'), OPF-3 (5' CCTGATCACC 3'), OPF-10 (5' GGAAGCTTGG 3'), OPO-7 (5' CAGCACTGAC 3'), OPO-10 (5' TCAGAGCGCC 3') and OPO-20 (5' ACACACGCTG $\left.3^{\prime}\right)$. DNA amplification reactions were performed in a volume of $25 \mu \mathrm{L}$ containing approximately $10 \mathrm{ng}$ total DNA, $0.4 \mu \mathrm{M}$ of a single decanucleotide, $0.2 \mathrm{mM}$ of each dNTP, $1.5 \mathrm{mM}$ of $\mathrm{MgCl} 2$ and $1 \mathrm{U}$ Taq DNA polymerase in the buffer provided by the enzyme manufacturer (Biotools). The PCR amplifications were performed in a DNA Thermal Cycler (Eppendorf) using one cycle of $1 \mathrm{~min}$ at $94{ }^{\circ} \mathrm{C}$, followed by 35 cycles of $45 \mathrm{~s}$ at $92{ }^{\circ} \mathrm{C}, 1 \mathrm{~min}$ at $37{ }^{\circ} \mathrm{C}$ and $2 \mathrm{~min}$ at $72{ }^{\circ} \mathrm{C}$, and a final cycle of $3 \mathrm{~min}$ at $72{ }^{\circ} \mathrm{C}$. Aliquots of $12 \mu \mathrm{L}$ of amplification products were loaded onto $1.5 \%$ (w/v) agarose gels for electrophoresis (carried out at $110 \mathrm{~V}$ ) using $1 \times$ TBE running buffer (Sambrook et al. 1989), followed by staining with ethidium bromide $\left(0.5 \mu \mathrm{g} \mathrm{mL}^{-1}\right)$ for 7-10 min and photographed under UV light. The size of the amplified bands was related by reference to the molecular size marker (100 Base- Pair Ladder, GE Healthcare). All the amplifications were repeated at least twice, and only bands reproducible in several runs were considered for analysis.

\subsubsection{AFLP analysis}

AFLP analysis was performed according to Vos et al. (1995). Genomic DNA was digested with two restriction enzymes: Eco RI and Mse I. The digestion was carried out in a final volume of $35 \mu \mathrm{l}$, using $12.5 \mathrm{U}$ of Eco RI, $6 \mathrm{U}$ of Mse I (New England Biolabs), $500 \mathrm{ng}$ of genomic DNA in 1× buffer RL [10 mM Tris-HAc (pH 7.5), $50 \mathrm{mM} \mathrm{KAc,} 10 \mathrm{mM} \mathrm{MgAc}$, $5 \mathrm{mM}$ DTT] and maintained for $3 \mathrm{~h}$ at $37^{\circ} \mathrm{C}$. Two different adaptors that had been designed to avoid the reconstruction of these restriction sites, one for the Eco RI sticky ends and one for the Mse I sticky ends, were ligated to the DNA fragments by adding to the digestion $5 \mu \mathrm{L}$ of a mix containing 5 pmol Eco RI adaptor, 50 pmol Mse I adaptor, $10 \mathrm{mM}$ ATP, and $1.2 \mathrm{U}$ T4 DNA ligase (Boehringer) in $1 \times$ buffer RL. The ligation was incubated for $3 \mathrm{~h}$ at $37^{\circ} \mathrm{C}$ and 
overnight at $4{ }^{\circ} \mathrm{C}$. Digested and ligated DNA fragments were diluted fivefold to be used as templates for the first amplification reaction. The PCR reaction was performed in $20 \mu \mathrm{L}$ containing $30 \mathrm{ng}$ of each primer Eco $R I+\mathrm{A}$ and $M s e I+\mathrm{C}, 0.2 \mathrm{mM}$ of each dNTP, $1.5 \mathrm{mM}$ $\mathrm{MgCl} 2,0.4 \mathrm{U}$ of Taq DNA polymerase (Biotaq, Bioline) and $3 \mu \mathrm{L}$ of diluted fragments in the $1 \times$ PCR buffer provided by the manufacturer (Bioline). PCR amplification consisted of 28 cycles of $30 \mathrm{~s}$ at $94{ }^{\circ} \mathrm{C}, 1 \mathrm{~min}$ at $60{ }^{\circ} \mathrm{C}$ and $1 \mathrm{~min}$ at $72{ }^{\circ} \mathrm{C}$, and was carried out in a MJ thermocycler. Preamplified fragments were diluted tenfold to be used as starting material for the selective amplification. In this amplification, only the Eco RI primer was labelled with FAM fluorochrome; both, the Eco RI and the Mse I primers, contained the same sequences as those used in the preamplification but with three selective nucleotides at the 3 ' end. For the selective amplification the primers used were: A2 (Eco+ACG/ Mse+CCA); A3 (Eco+ACA/ $M s e+\mathrm{CAG}) ; \mathrm{C} 1$ (Eco+ACC/ Mse+CCA); C2 (Eco+ACC/ Mse+CAG); C5 (Eco+ACA/ $M s e+\mathrm{CAT})$; C6 (Eco+ACA/Mse+CCA); C7 (Eco+AGT/ Mse+CAT). The PCR reaction was performed in a volume of $20 \mu \mathrm{L}$ containing $6 \mathrm{ng}$ of labeled Eco RI primer, $30 \mathrm{ng}$ of Mse I primer, $0.1 \mathrm{mM}$ of each dNTP, $1.5 \mathrm{mM} \mathrm{MgCl} 2,0.4 \mathrm{U}$ of Taq DNA polymerase, and $5 \mu \mathrm{L}$ of diluted preamplified DNA in the $1 \times$ PCR buffer provided by the manufacturer (Biotaq, Bioline). The selective amplification was performed using 1 cycle of $30 \mathrm{~s}$ at $94{ }^{\circ} \mathrm{C}, 30 \mathrm{~s}$ at $65{ }^{\circ} \mathrm{C}, 1 \mathrm{~min}$ at $72{ }^{\circ} \mathrm{C}$ followed by 12 cycles in which the annealing temperature decreases $0.7{ }^{\circ} \mathrm{C}$ per cycle, followed by 23 cycles of $1 \mathrm{~min}$ at $94{ }^{\circ} \mathrm{C}, 30 \mathrm{~s}$ at $56^{\circ} \mathrm{C}$, and $1 \mathrm{~min}$ at $72{ }^{\circ} \mathrm{C}$. Amplification products were analysed in an automated ABI3730 sequencer by the company SECUGEN S.L. (Madrid, Spain). The resulted electropherograms were analysed using GeneMarker® v 1.90 software (SoftGenetics, LLC).

\subsubsection{Data analysis}

Five beads were cultured on each Petri dish containing recovery medium; two and six replicates were used for non-cryopreserved ( $\mathrm{LN}-)$ and cryopreserved $(\mathrm{LN}+)$ samples, respectively. Non-cryopreserved samples were subjected to the same treatments with the exception of the immersion in LN and in the warm water bath. Survival and recovery was recorded after the 8-week recovery period. Data were analyzed by logistic regression for events data and pair-wise comparisons were carried out by LSD with a confident interval of $95 \%$ (Agresti 2002). Analyses were carried out with the Generalized Lineal Models procedure of the program IBM SPSS Statistics 20. 
Amplified fragments from the RAPD analyses were scored as present (1) or absent (0). Genetic similarities were calculated using the Jaccard similarity coefficient (Jaccard 1908): $\mathrm{GS}(\mathrm{ij})=\mathrm{a} /(\mathrm{a}+\mathrm{b}+\mathrm{c})$; where $\mathrm{a}$ is the number of polymorphic DNA fragments common to both individuals, $b$ is the number of fragments present in $i$ and absent in $j$, and $c$ is the number of fragments present in $\mathrm{j}$ and absent in $\mathrm{i}$. The resultant matrix was subjected to cluster analysis by the unweighted pair-group method analysis (UPGMA) and a dendrogram was constructed from the clustering results with the TREE program. These analyses were performed using the computer program NTSYS-PC v. 1.80 (Rohlf 1992). Similar analyses were carried out with AFLP results. Percentage of genetic stable samples (similarity of $100 \%$ or $95 \%$ with the "VITRO" samples) was analysed using a logistic regression method for binary data and pairwise comparisons were carried out by LSD with a confident interval of $95 \%$. Analyses were carried out with the Generalized Lineal Models procedure of the program IBM SPSS Statistics 20 .

\subsection{Results}

Survival and recovery were high (100-90 \% and 70-90\%, respectively) in noncryopreserved shoots of 'MEN 186', with no significant differences among treatments (Fig. 5.1 A). After cryopreservation, survival was maintained high (86 to $97 \%$ ); however, recovery decreased significantly (13- $23 \%$ ), with no significant difference among treatments (Fig. 5.1 A). Recovery rates in cryopreserved shoots of 'MEN 198' were higher than in 'MEN 186' (Fig. $5.1 \mathrm{~B})$. In this genotype, survival ranged from $37 \%(0.28 \mathrm{mM}$ ascorbic acid) to $77 \%(0.16 \mathrm{mM}$ GHS $)$. None of the antioxidant treatments significantly increased survival compared to the control treatment (no antioxidant). Similarly, recovery was not improved by the antioxidant treatments and was significantly decreased in the case of $0.24 \mathrm{mM}$ GHS.

The eight RAPD primers used yielded 75 and 94 scorable bands for the 'MEN 198' and 'MEN 186' samples, respectively, ranging from 2500 to 300 bp. From these results, one divergence in the presence or absence of a single amplified fragment represented a dissimilarity ranging from 1.5 to $1.6 \%$. In 'MEN 186', 39 RAPD markers (41.5\%) resulted monomorphic, and the polymorphism affected 37 out of 59 samples (63\%). However, this percentage decreased in 'MEN 198' to 44\% (22 non stable samples out of 50), with 29 polymorphic RAPD markers. 
The AFLP profiles were generated from part of the same samples analyzed with RAPD markers: 29 samples in 'MEN 186' and 25 for 'MEN 198', including the in vitro control. The used primer combinations produced 126 and 139 scorable fragments, respectively for each genotype. From these results, one divergence in the presence or absence of a single amplified fragment represented a dissimilarity ranging from 1.1 to $1.5 \%$. Monomorphic markers represented $38.9 \%$ of the total in 'MEN 186' and a higher value, $59.7 \%$, was observed in 'MEN 198'. A representation of polymorphic samples of 'MEN 186' is shown in Fig. 5.2. The first and second electropherogram belong to the control (VITRO) and G2+L60 samples, both in the cluster at $100 \%$ of similarity. In the following electropherograms some differences as absence or presence of new fragments are observed in the samples VE+cL120, $\mathrm{G} 1+\mathrm{C} 37$ and $\mathrm{VE}+\mathrm{C} 118$.

$\mathbf{A}$

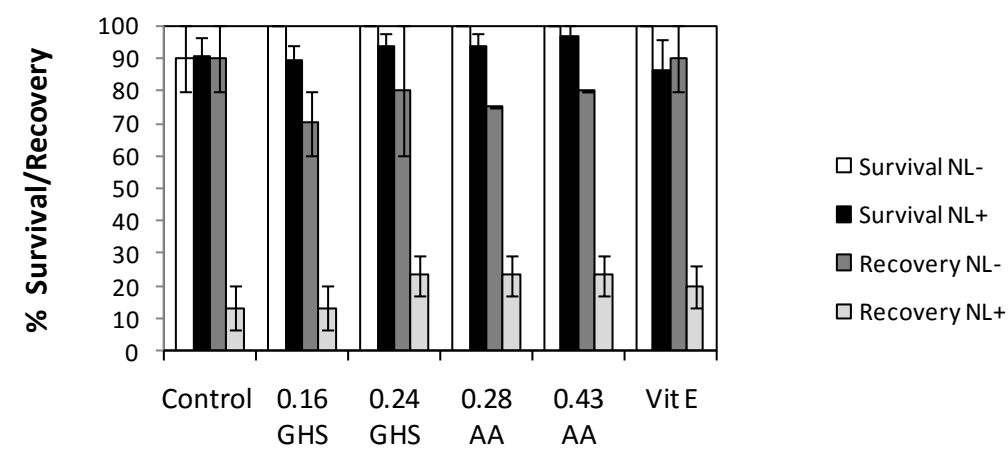

Antioxidant treatment (concentrations in $\mathrm{mM}$ )

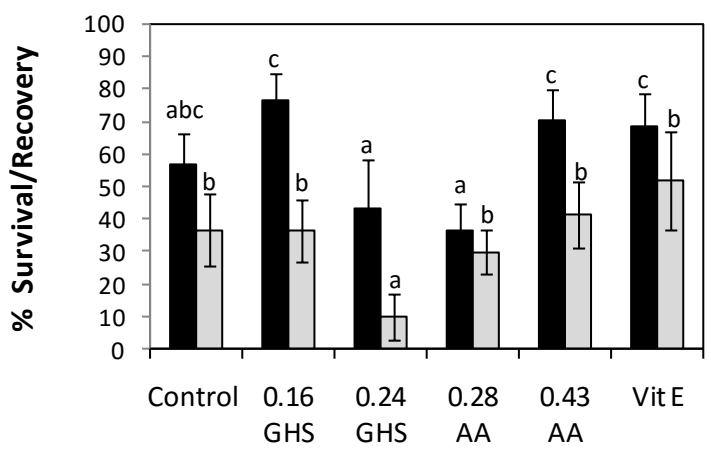

Survival NL+

$\square$ Recovery NL+

Antioxidant treatment (concentrations in $\mathrm{mM}$ )

Figure 5.1. Survival and recovery of mint shoot tips (a genotype 'MEN 186' and b 'MEN 198') after cryopreservation by encapsulation-dehydration. NL-: non-cryopreserved tips; NL+: cryopreserved tips; Control: pretreatment on $0.3 \mathrm{M}$ sucrose without antioxidants; 0.16 GHS and 0.24 GHS: $0.16 \mathrm{mM}$ or $0.24 \mathrm{mM}$ glutathione, respectively; 0.28 AA and $0.43 \mathrm{AA}$ : $0.28 \mathrm{mM}$ or $0.43 \mathrm{mM}$ ascorbic acid, respectively; VitE: a-tocopherol. All these antioxidants 
included in the $0.3 \mathrm{M}$ sucrose medium. Bar: standard error. For survival and recovery, means with the same letter are not significantly different according to a pair-wise comparison by $\operatorname{LSD}(\alpha=0.05)$.
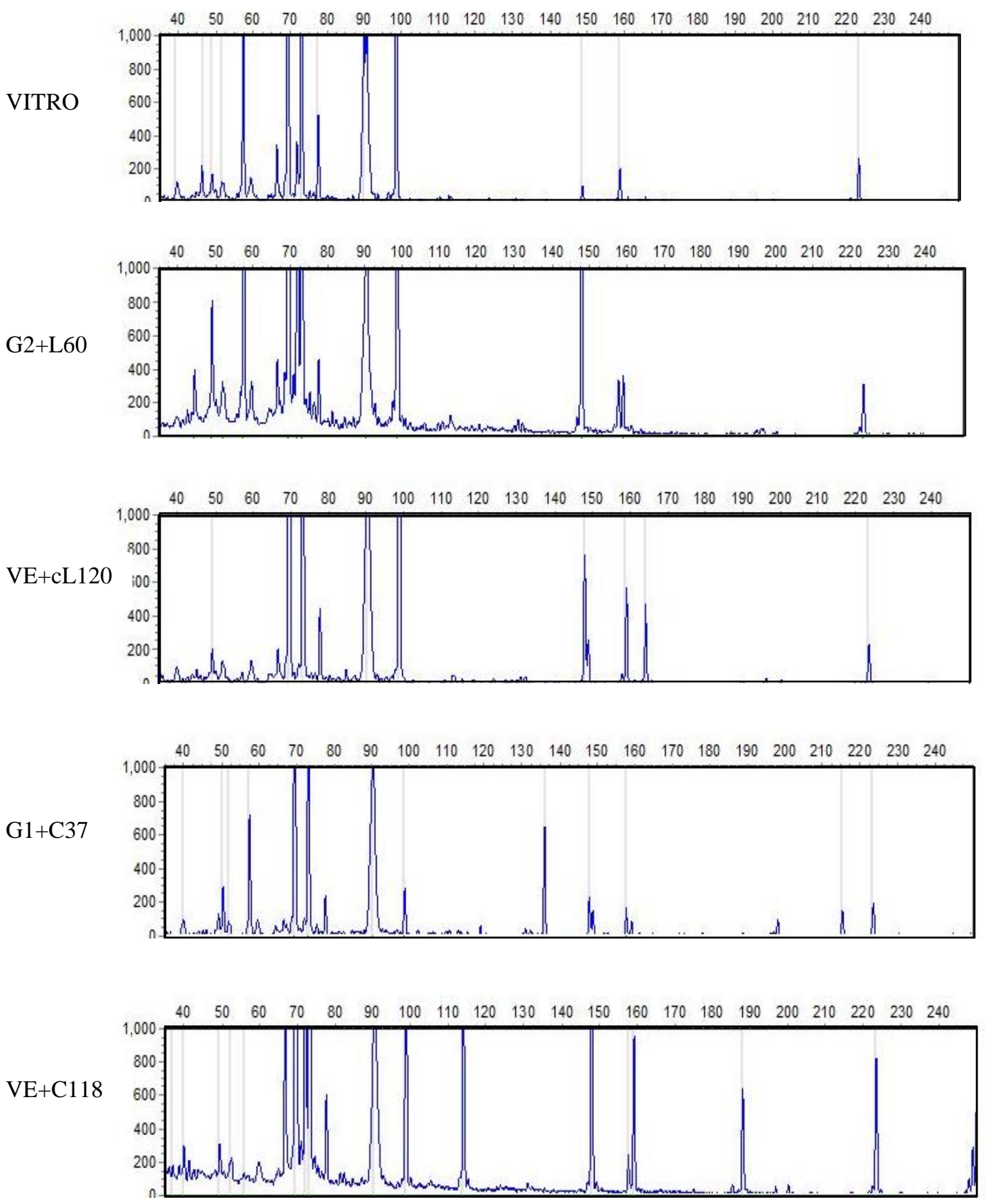

Figure 5.2. AFLP electropherograms of some samples from accession 'MEN 186' amplified with the primers Eco+ACA/ Mse+CAG. The x-axis represents the size (bp) of the DNA fragments and the $y$-axis indicates the amount of the amplified products. 
According to the RAPD analysis of genotype 'MEN 186', the minimum similarity observed among the 60 samples, including the in vitro control, was $62 \%$ (Fig. 5.3). Most of the 22 identical (100\% similarity) samples to the in vitro control corresponded to Vitamin $\mathrm{E}$ treatment (Table 5.1). The percentage of Vitamin E stable samples (72.7\%) was significantly different to the percentages obtained with control and the two glutathione treatments (0- $27 \%$; Table 5.1). There was no significant difference when non-cryopreserved or cryopreserved samples were considered (41.7\% and $32.3 \%$, respectively). When data were analysed according to the type of plant material, $80.0 \%$ of shoots were stable, while for callus at the base of shoots ("cL") and callus ("C") this figure decreased significantly to $16.7 \%$ and $14.3 \%$, respectively (Table 5.1).

Table 5.1. Percentage of stable samples (compared to the in vitro plant material) recovered from mint 'MEN 186' shoot apices, according to RAPD markers (100\% similarity) and AFLP markers (95\% similarity). Type of plant material: "L"= shoot; "cL"= callus at the base of the shoot; "C"= callus. Percentages with the same letter are not significantly different according to a pair-wise comparison by $\operatorname{LSD}(\alpha=0.05)$.

\begin{tabular}{lc|c|c}
\hline & \multicolumn{2}{c}{ Percentage of stable samples (number of samples } \\
analysed) & AFLP analysis \\
\cline { 1 - 3 } & \multicolumn{2}{c}{ RAPD analysis } & 95 \% similarity \\
\cline { 2 - 3 } 100 \% similarity & $\mathbf{9 5 \% ~ s i m i l a r i t y ~}$ & \\
Pretreatment & & & \\
Control & $20.0(10) \mathrm{ab}$ & $40.0 \mathrm{a}$ & $40.0(5)$ \\
$0.16 \mathrm{mM}$ glutathione & $0(9) \mathrm{a}$ & $44.4 \mathrm{ab}$ & $50.0(4)$ \\
$0.24 \mathrm{mM}$ glutathione & $27.0(11) \mathrm{bc}$ & $54.5 \mathrm{ab}$ & $50.0(4)$ \\
$0.28 \mathrm{mM}$ ascorbic acid & $62.5(8) \mathrm{cd}$ & $62.5 \mathrm{ab}$ & $60.0(5)$ \\
$0.43 \mathrm{mM}$ ascorbic acid & $40.0(10) \mathrm{bcd}$ & $80.0 \mathrm{bc}$ & $40.0(5)$ \\
Vitamin E & $72.7(11) \mathrm{d}$ & $100 \mathrm{c}$ & $60.0(5)$ \\
\hline Cryopreservation & & & \\
Non-cryopreserved & $41.7(24)$ & 75.0 & $50.0(10)$ \\
Cryopreserved & $32.3(35)$ & 57.1 & $50.0(18)$ \\
\hline Type of plant material & & & \\
"L" & $79.0(19) \mathrm{b}$ & $100 \mathrm{~b}$ & $75.0(12) \mathrm{b}$ \\
"cL" & $21.0(19) \mathrm{a}$ & $57.9 \mathrm{a}$ & $44.4(9) \mathrm{ab}$ \\
“C” & $14.3(21) \mathrm{a}$ & $38.0 \mathrm{a}$ & $14.3(7) \mathrm{a}$ \\
\hline Total & $37.3(59)$ & 64.4 & $50.0(28)$ \\
\hline
\end{tabular}




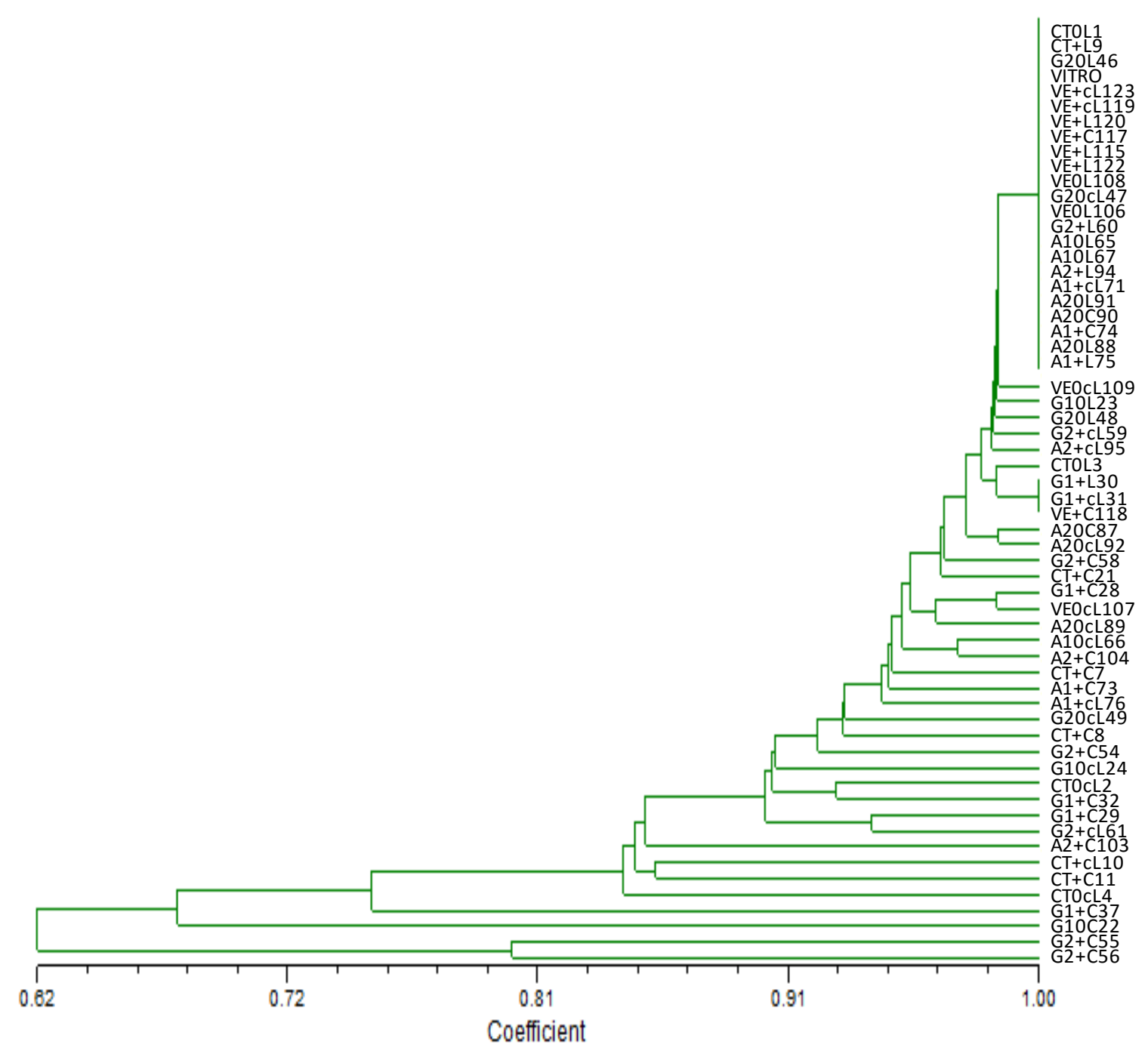

Figure 5.3. Dendrogram generated by the UPGMA method using Jaccard's similarity coefficient, based on RAPD markers of samples from mint plant material recovered 8 weeks after cryopreservation of accession 'MEN 186', using the encapsulation-dehydration technique. Firts two letters/numbers represent the pretreatment: "CT"= control; "G1"=0.16 $\mathrm{mM}$ glutathione; "G2"=0.24 mM glutathione; "A1"=0.28 mM ascorbic acid; "A2"=0.43 mM ascorbic acid; "VE"= Vitamin E. Third number/symbol: "0"= non-cryopreserved; "+"= cryopreserved. The type and number of samples follow: "L"= shoot; "cL"= callus at the base of the shoot; "C"= callus. 
Considering $95 \%$ similarity level of the RAPD markers to the in vitro control (Table 5.1; Fig. 5.3) 38 samples (64.4\%) were stable in 'MEN 186'. Treatments analysed showed similar behaviour than the one observed at $100 \%$ similarity: best results were obtained with Vitamin E (100\% stable samples), which shows significant differences with the other treatments except with $0.43 \mathrm{mM}$ ascorbic acid (80\% stable samples). On the other hand, the lowest percentages of stable plant material were obtained from the control and $0.16 \mathrm{mM}$ glutathione treated samples (40\% and $44.4 \%$, respectively). However, in this analysis at 95 $\%$ similarity, when non-cryopreserved or cryopreserved samples were considered $(75 \%$ and $57.1 \%$, respectively) differences were observed, although there were not significant. When the data were considered according to the type of sample, $100 \%$ of shoots were stable, and this value was, as it was pointed at $100 \%$ similarity, significantly different to the percentage obtained from both types of callus samples.

According to AFLP analysis, the minimum similarity observed among the 28 samples analysed of genotype 'MEN 186' was $75 \%$ (Fig. 5.4). Only three samples were similar at $100 \%$ to the in vitro control, and fourteen samples were stable at $95 \%$ similarity level. The treatments from which more stable samples were recovered were Vitamin E and $0.28 \mathrm{mM}$ ascorbic acid (60.0\%), although there were no significant differences with the percentages obtained with the other treatments (Table 5.1). Non-cryopreserved and cryopreserved plant material showed the same results (50\% stability). Again, higher stability percentage was found among shoots $(75.0 \%)$, although it was not significantly different to the stability of callus at the base of shoots $(44.4 \%)$. 


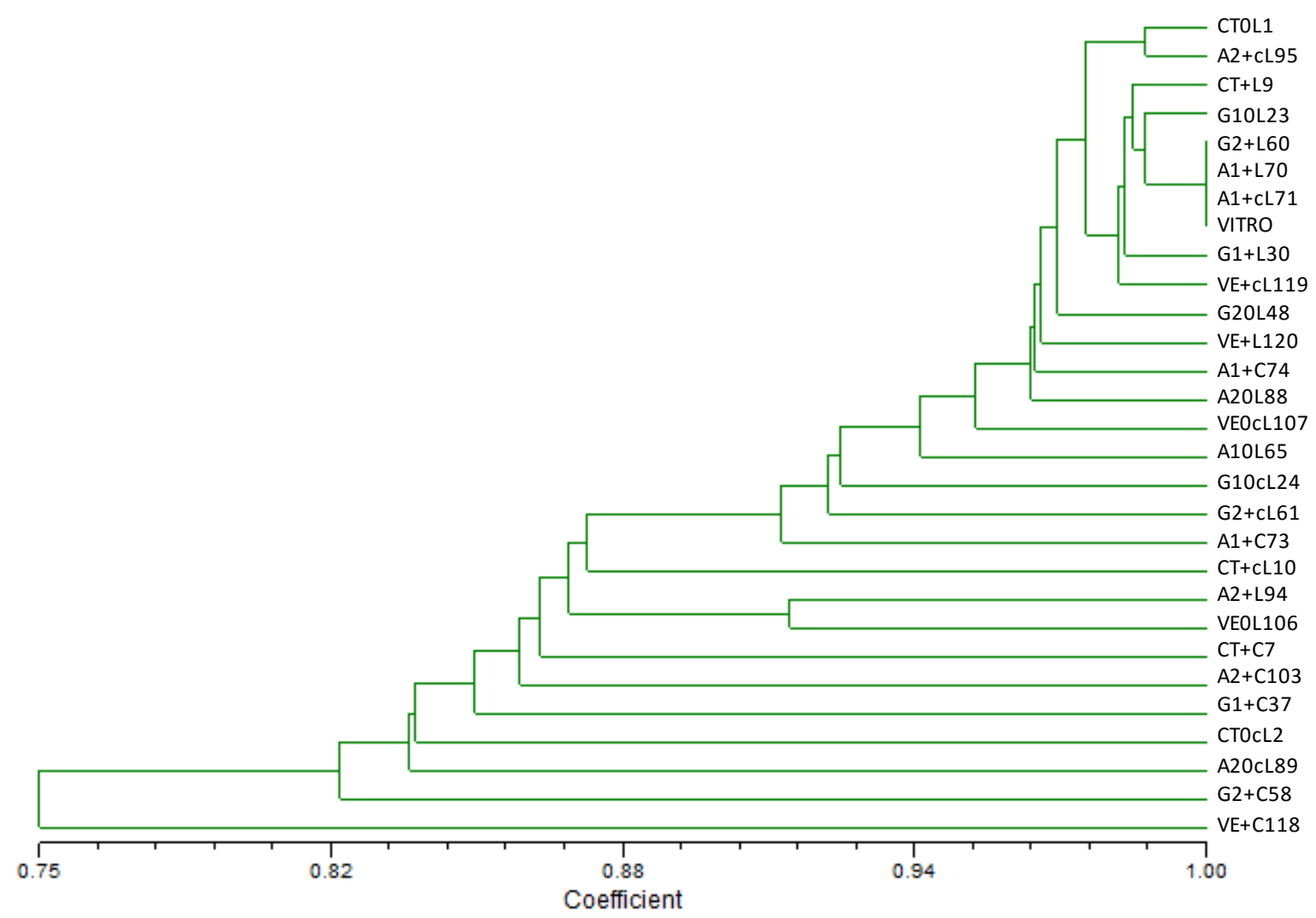

Figure 5.4 Dendrogram generated by the UPGMA method using Jaccard's similarity coefficient, based on AFLP markers of samples from mint plant material recovered 8 weeks after cryopreservation of accession 'MEN 186', using the encapsulation-dehydration technique. Firts two letters/numbers represent the pretreatment: "CT"= control; "G1"=0.16 $\mathrm{mM}$ glutathione; "G2"=0.24 mM glutathione; "A1"=0.28 mM ascorbic acid; "A2"=0.43 mM ascorbic acid; "VE"= Vitamin E. Third number/symbol: "0"= non-cryopreserved; "+"= cryopreserved. The type and number of samples follow: "L"= shoot; "cL"= callus at the base of the shoot; "C"= callus. 
In genotype 'MEN 198', the minimum similarity observed was $90 \%$, using both RAPD and AFLP markers (Figs. 5.5 and 5.6). Twenty eight samples (56\%) were stable at $100 \%$ similarity using RAPD markers. This percentage increased to $90 \%$ when considering the similarity level of $95 \%$, nearly the same value was obtained in the AFLP analysis $(91.7 \%$; Table 5.2). There was not a significant difference among the percentages of stable recovered plant material regardless the antioxidant treatment used in any of the analyses. Both types of markers revealed significant differences in the stability according to the type of material (Table 5.2).

Table 5.2. Percentage of stable samples (compared to the in vitro plant material) recovered after cryopreservation of mint 'MEN 198'shoot tips, according to RAPD markers (100\% similarity) and AFLP markers (95 \% similarity). Type of plant material: "L"= shoot; "cL"= callus at the base of the shoot; "C"= callus. Percentages with the same letter are not significantly different according to a pair-wise comparison by $\operatorname{LSD}(\alpha=0.05)$.

\begin{tabular}{lc|c|c}
\hline \multicolumn{4}{c}{ Percentage of stable samples (number of samples analysed) } \\
\hline & $\begin{array}{c}\text { RAPD analysis } \\
\text { (100 \% similarity) }\end{array}$ & $\begin{array}{c}\text { RAPD analysis } \\
\text { (95 \% similarity) }\end{array}$ & $\begin{array}{c}\text { AFLP analysis } \\
\text { (95 \% similarity })\end{array}$ \\
\hline Pretreatment & & & \\
control & $28.6(7)$ & 85.7 & $100(4)$ \\
$0.16 \mathrm{mM}$ glutathione & $70(10)$ & 90.0 & $100(4)$ \\
$0.24 \mathrm{mM}$ glutathione & $42.9(7)$ & 85.7 & $66.7(3)$ \\
$0.28 \mathrm{mM}$ ascorbic acid & $62.5(8)$ & 87.5 & $100(4)$ \\
$0.43 \mathrm{mM}$ ascorbic acid & $50(8)$ & 87.5 & $80(5)$ \\
Vitamin E & $70(10)$ & 100 & $100(4)$ \\
\hline Type of plant material & & & $100(10) \mathrm{b}$ \\
"L" & $76.2(21) \mathrm{b}$ & $100 \mathrm{~b}$ & $100(10) \mathrm{b}$ \\
"cL" & $50.0(20) \mathrm{ab}$ & $90.0 \mathrm{ab}$ & $50.0(4) \mathrm{a}$ \\
"C" & $22.2(9) \mathrm{a}$ & $66.7 \mathrm{a}$ & $91.7(24)$ \\
\hline Total & $56.0(50)$ & 90.0 &
\end{tabular}




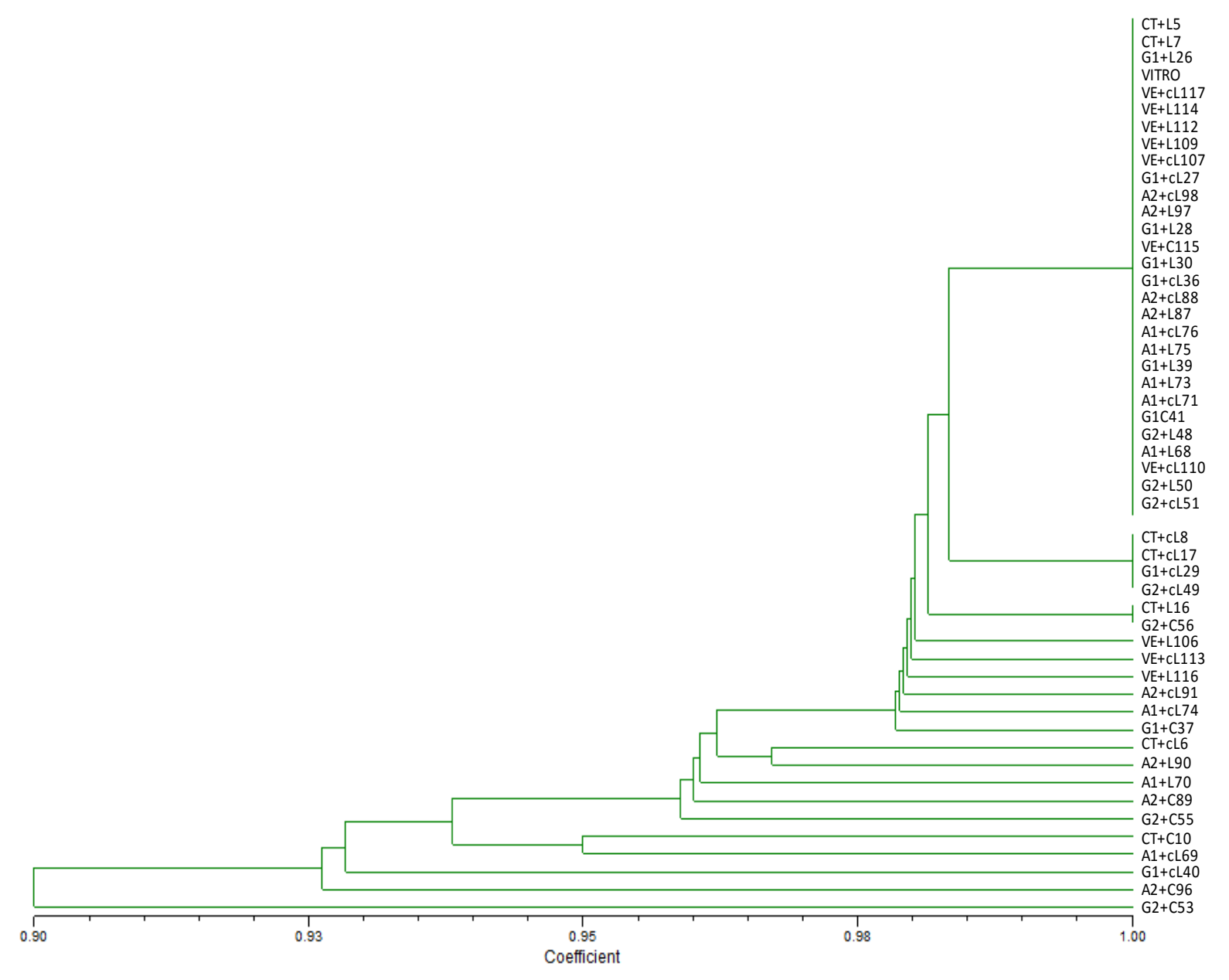

Figure 5.5. Dendrogram generated by the UPGMA method using Jaccard's similarity coefficient, based on RAPD markers of samples from mint plant material recovered 8 weeks after cryopreservation of accession 'MEN 198', using the encapsulation-dehydration technique. Firts two letters/numbers represent the pretreatment: "CT"= control; "G1"=0.16 $\mathrm{mM}$ glutathione; "G2"=0.24 mM glutathione; "A1"=0.28 mM ascorbic acid; "A2"=0.43 mM ascorbic acid; "VE"= Vitamin E. Third number/symbol: "0"= non-cryopreserved; "+"= cryopreserved. The type and number of samples follow: "L"= shoot; "cL"= callus at the base of the shoot; "C"= callus. 


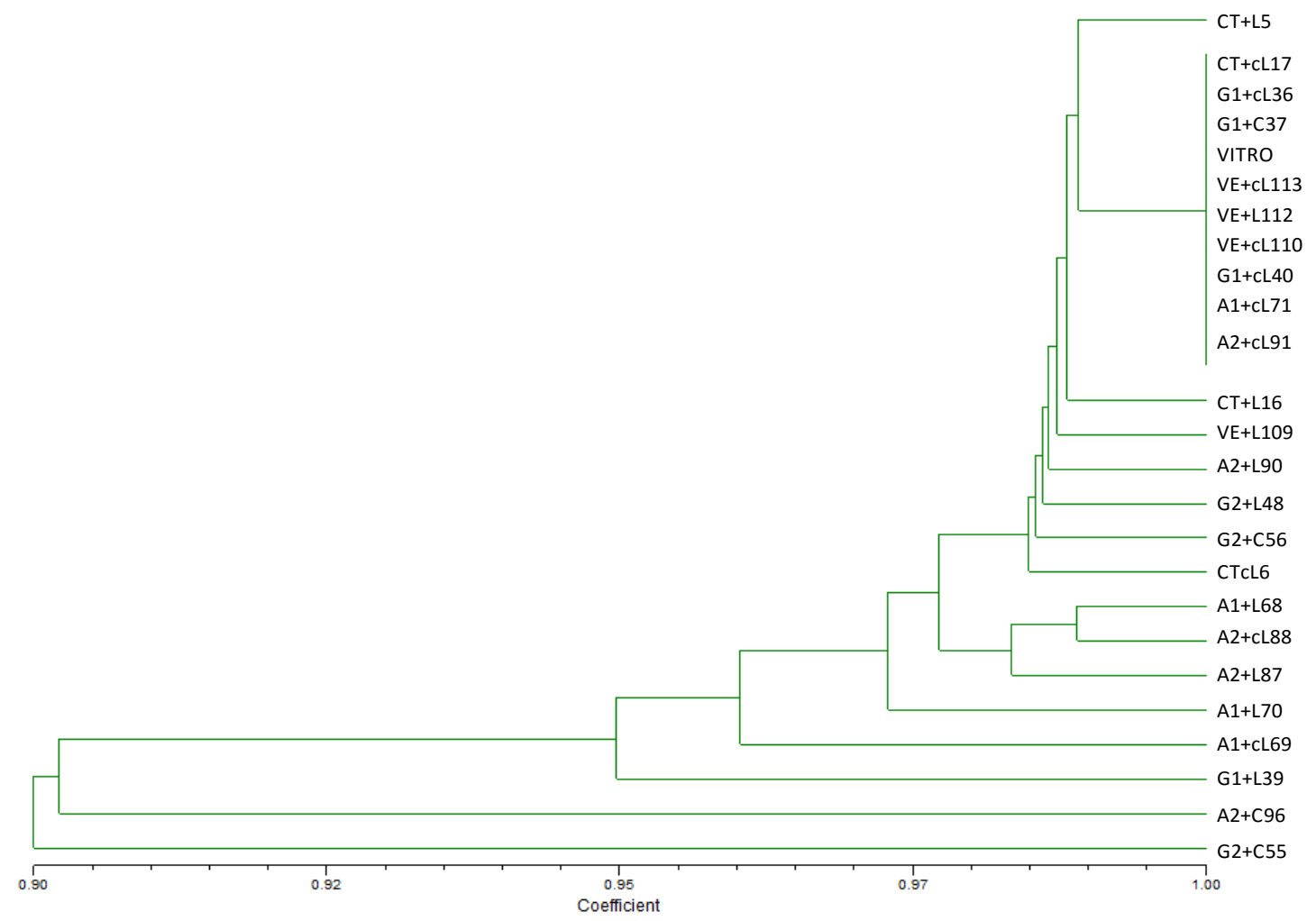

Figure 5.6. Dendrogram generated by the UPGMA method using Jaccard's similarity coefficient, based on AFLP markers of samples from mint plant material recovered 8 weeks after cryopreservation of accession 'MEN 198', using the encapsulation-dehydration technique. Firts two letters/numbers represent the pretreatment: "CT"= control; "G1"=0.16 $\mathrm{mM}$ glutathione; "G2"=0.24 mM glutathione; "A1"=0.28 mM ascorbic acid; "A2"=0.43 mM ascorbic acid; "VE"= Vitamin E. Third number/symbol: "0"= non-cryopreserved; "+"= cryopreserved. The type and number of samples follow: "L"= shoot; "cL"= callus at the base of the shoot; "C"= callus.

\subsection{Discussion}

The influence of antioxidant substances used during an encapsulation-dehydration cryopreservation protocol on the recovery of mint shoot tips and the genetic stability of the recovered material has been assessed. In the present study, the use of antioxidant substances in the preculture medium (with $0.3 \mathrm{M}$ sucrose) did not improve recovery of mint shoot tips after cryopreservation. However, there are several works in which antioxidants have improved recovery after cryopreservation when the vitrification procedure was used (Wang and Deng 2004; Chua and Normah 2011; Uchendu et al. 2010a, 2010b, 2013, 2014). Not only we have 
not observed a beneficial effect, but the addition of $0.24 \mathrm{mM}$ glutathione resulted detrimental for recovery in one of the mint genotypes ('MEN 198') studied in this work. Uchendu et al. (2010a, 2010b) found that glutathione and Vitamin E improved recovery after cryopreservation by vitrification of two Rubus genotypes, when applied in any of the protocol steps: pretreatment, loading, rinsing, or regrowth. Vitamin C improved recovery when used in the first three steps, and also when added in recovery medium lacking iron (Uchendu et al. 2010b). On the contrary, we have not found any improvement in the recovery of mint after cryopreservation with the use of these substances. However, it must be taken into account the fact that, in the present work, the antioxidants were added only in one step of the protocol. Besides, another difference with the studies mentioned above is that in our experiment the protocol analysed was encapsulation-dehydration instead of vitrification. For these reasons, further investigation could be necessary to establish if the stresses imposed by the vitrification procedure could differ to those of the encapsulation-dehydration protocol, and, likewise, the step of the protocol in which antioxidants are applied.

Although we have not found any reference relating genetic stability to the use of antioxidants in cryopreservation protocols, our hypothesis was that the improvement in regrowth produced by these substances would imply a higher genetic stability. Nevertheless, the use of glutathione, ascorbic acid or Vitamin E applied in the medium supplemented with $0.3 \mathrm{M}$ sucrose (pretreatment previous to the encapsulation and incubation in $0.75 \mathrm{M}$ sucrose), did not improved recovery in the two mint genotypes studied. However, according to RAPD markers results, Vitamin E seems to improve stability in the less stable genotype ('MEN 186'). In a previous work of our group where the effect of cryopreservation technique, genotype and culture medium on genetic stability was studied, genotype 'MEN 198' showed higher percentage of stable samples than 'MEN 186' (Martin et al. 2015). Similar results have been obtained in the present study. The RAPD markers revealed $64 \%$ of stable samples (for $95 \%$ similarity, Table 5.1) in 'MEN 186', while that valued was $90 \%$ for 'MEN 198' (Table 5.2).

The percentage of stable samples differed among the plant type materials recovered. In both genotypes, that percentage was always higher in the recovered shoots compared to the callus tissues (either "cL" or "L"; Tables 5.1 and 5.2). However, it was only significantly different to the percentage of stable samples of callus at the base of shoots ("cL") in "MEN 186 ' when $100 \%$ similarity was considered. The percentage of stable callus ("CC") was always significantly lower than that of recovered shoots ("L" samples). The dedifferentiation process 
in callus, followed by redifferentiation events when indirect shoots are developed, leads to frequent genetic modifications (Munthali et al. 1996; Al-Zahim et al. 1999; Salvi et al. 2001). A higher genetic stability in recovered shoots is an expected result even when they derived from instable callus (Miñano et al. 2014). This is not the case in our study since "cL" samples and their corresponding shoot ("L") were identical (e.g. samples G20L46 and G20cL47 in 'MEN 186') or closed related (e.g. CT+L9 and CT+cL10 in “'MEN 186'; Fig. 5.3).

As we observed in our previous study (Martín et al. 2015), the instability observed was not due to the extreme low temperature ("LN") as there were not differences between non cryopreserved (but treated) and cryopreserved apices of 'MEN 186'.

Results obtained in this work related to genetic stability in mint cryopreserved apices conclude in the genotype effect, pretreatment influence (although not the use of antioxidants), no effect of low temperatures and instability associated to unorganized tissues. All this results were observed in a previous work using RAPD markers, in this one AFLP markers have also been included and both techniques resulted useful in the detection of genetic instability in mint.

Acknowledgements: This research was supported by the Spanish Government project AGL2010-21989-C02-01. C.K. is supported by a grant from Universidad Politécnica de Madrid. Technical support from C. Sansegundo, M. Huertas and C. Ruiz is appreciated.

\subsection{Bibliography}

Agresti A (2002) Categorical Data Analysis. John Wiley \& Sons, New Jersey. 2nd Edition.

Alscher RG, Hess JL (1993) Antioxidant in Higher Plants. CRC Press, Boca Raton (FL)

Al-Zahim MA, Ford-Lloyd BV, Newbury HJ (1999) Detection of somaclonal variation in garlic (Allium sativum L.) using RAPD and cytological analysis. Plant Cell Rep 18:473-477

Arora A, Sairam RK, Srivastava GC (2002) Oxidative stress and antioxidative systems in plants. Curr Sci 82: 1227-1273 
Bhattacharjee S (2011) Sites of generation and physicochemical basis of formation of reactive oxygen species in plant cell. In Gupta SD (ed.) Reactive oxygen species and antioxidants in higher plants. Science Publishers Enfield (USA), pp 1-30

Chua SP, Normah MN (2011) Effect of preculture, PVS2 and vitamin C on survival of recalcitrant Nephelium ramboutan-ake shoot tips after cryopreservation by vitrification. CryoLetters 32:506-515

Engelmann F, Gonzalez-Arnao MT, Wu Y, Escobar R (2008) The development of encapsulation dehydration. In Reed BM (ed.) Plant Cryopreservation: a Practical Guide. Springer, pp 59-92

Gawel NJ, Jarret RL (1991) A modified CTAB DNA extraction procedure of Musa and Ipomoea. Plant Mol Biol Rep 9: 262-266

Gill SS, Tuteja N (2010) Reactive oxygen species and antioxidant machinery in abiotic stress tolerance in crop plants. Plant Physiol Bioch 48: 909-930

Imlay JA (2003) Pathways of oxidative damage. Ann Rev Microbiol 57:395-418

Johnston JW, Harding K, Benson EE (2007) Antioxidant status and genotypic tolerance of Ribes in vitro cultures to cryopreservation. Plant Sci 172:524-534

Kovalchuk I (2011) multiple roles of radicals in plants. In Gupta SD (ed.) Reactive Oxygen Species and Antioxidants in Higher Plants. Science Publishers, Enfield (NH), pp 31-44

Lynch PT, Siddika A, Johnston JW, Trigwella SM, Mehraa A, Benelli C, Lambardi M, Benson EE (2011) Effects of osmotic pretreatments on oxidative stress, antioxidant profiles and cryopreservation of olive somatic embryos. Plant Sci 181:47-56

Martín C, Cervera MT, González-Benito ME (2011) Genetic stability analysis of chrysanthemum (Chrysanthemum $\times$ morifolium Ramat) after different stages of an encapsulation-dehydration cryopreservation protocol. J Plant Physiol 168:158-66

Martín C, Kremer C, González I, González-Benito ME (2015) Influence of the cryopreservation technique, recovery medium and genotype on genetic stability of mint cryopreserved shoot tips. Plant Cell Tiss Organ Cult 122:185-195 
Miñano HS, Ibáñez MA, González-Benito ME, Martín C (2014) Sequential study of the genetic stability of callus and regenerated shoots in chrysanthemum. Propag Ornam Plants 14:57-67

Munthali MT, Newbury HJ, Ford-Lloyd BV (1996) The detection of somaclonal variants of beet using RAPD. Plant Cell Rep 15:474- 478

Murashige T, Skoog F (1962) A revised medium for rapid growth and bio assays with tobacco tissue cultures. Physiol Plantarum 15:473-497

Reed BM (2001) Genotype considerations in temperate fruit crop cryopreservation. In Engelmann F, Takagi H (eds.) Cryopreservation of Tropical Plant Germplasm - current research progress and applications. JIRCAS/IPGRI, Tsukuba (Japan)/Rome (Italy), pp 200205

Reed BM (2014) Antioxidants and cryopreservation, the new normal? Acta Hort 1039: 4148

Ren L, Zhang D, Jiang X-N, Gai Y, Wang W-M, Reed BM, Shen X-H (2013) Peroxidation due to cryoprotectant treatment is a vital factor for cell survival in Arabidopsis cryopreservation. Plant Sci 212:37- 47

Rohlf FJ (1992) NTSYS-PC: Numerical Taxonomy and Multivariate Analysis System. Exeter Software, New York

Sakai A (2004) Plant cryopreservation. In: Fuller B, Lane N, Benson EE (eds.) Life in the Frozen State. CRC Press, London, New York, pp. 329-345

Salvi ND, George L, Eapen S (2001) Plant regeneration from leaf base callus of turmeric and random amplified polymorphic DNA analysis of regenerated plants. Plant Cell Tiss Organ Cult 66:113- 119

Sambrook J, Fritsch EF, Maniatis T (1989) Molecular cloning: a laboratory manual. Cold Spring Harbor Laboratory Press, 2nd ed., New York

Senula A, Keller J, Sanduijav T, Yohannes T (2007) Cryopreservation of cold-acclimated mint (Mentha spp.) shoot tips using a simple vitrification protocol. CryoLetters 28:1-12 
Sershen, Varghese B, Pammenter NW, Berjak P (2012) Cryo-tolerance of zygotic embryos from recalcitrant seeds in relation to oxidative stress - A case study on two amaryllid species. J Plant Physiol 169: 999- 1011

Teixeira AS, González-Benito ME, Molina-García AD (2014) Determination of glassy state by cryo-SEM and DSC in cryopreservation of mint shoot tips by encapsulationdehydration. Plant Cell Tiss Organ Cult 119:269-280

Uchendu EE, Leonard SW, Traber MG, Reed BM (2010b) Vitamins C and E improve regrowth and reduce lipid peroxidation of blackberry shoot tips following cryopreservation. Plant Cell Rep 29:25-35

Uchendu EE, Muminova M, Gupta S, Reed BM (2010a) Antioxidant and anti-stress compounds improve regrowth of cryopreserved Rubus shoot tips. In Vitro Cell.Dev.Biol-Plant 46:386-393

Uchendu EE, Shukla MR, Reed BM, Saxena PK (2013) Melatonin enhances the recovery of cryopreserved shoot tips of American elm (Ulmus americana L.). J Pineal Res 55:435-442

Uchendu EE, Shukla MR, Reed BM, Saxena PK (2014) An efficient method for cryopreservation of St John's Wort and tobacco: role of melatonin. Acta Hort 1039: 233-241

Vos P, Hogers R, Bleeker M, Reijans M, van de Lee T, Hornes M, et al. (1995) AFLP: a new technique for DNA fingerprinting. Nucleic Acids Res 23:4407-4414

Wang ZC, Deng XX (2004) Cryopreservation of shoot-tips of citrus using vitrification: effect of reduced form of glutathione. CryoLetters 25:43-50

Whitaker C, Beckett RP, Minibayeva FV, Kranner I (2010) Production of reactive oxygen species in excised, desiccated and cryopreserved explants of Trichilia dregeana Sond. S Afr J Bot 76:112-118

Xu J, Liu Q, Jia M, Liu Y, Li B, Shi Y (2014) Generation of reactive oxygen species during cryopreservation may improve Lilium $\times$ siberia pollen viability. In Vitro Cell Dev Biol-Plant 50:369-375 


\section{ESTUDIO SECUENCIAL DE UN PROTOCOLO DE CRIOCONSERVACIÓN MEDIANTE ENCAPSULACIÓN- DESHIDRATACIÓN: EFECTO DE LA UTILIZACIÓN DE ANTIOXIDANTES SOBRE LA ESTABILIDD GENÉTICA}

\subsection{Introducción}

La crioconservación es una técnica desarrollada para el mantenimiento de material biológico a la temperatura ultra baja del nitrógeno líquido $\left(-196{ }^{\circ} \mathrm{C}\right)$, donde el metabolismo celular se encuentra prácticamente detenido (Engelmann 2004). Entre las posibles técnicas para la conservación vegetal, es la que permite un almacenamiento más seguro del germoplasma a largo plazo, y es de especial interés para las especies con propagación vegetativa, genotipos estériles o semillas recalcitrantes. Se han desarrollado protocolos de crioconservación para una gran cantidad de especies (Sakai y Engelmann 2007). Sin embargo, existe preocupación ante la posible aparición de variación genética en las plantas crioconservadas. Estudios recientes han informado de la estabilidad genética (Turner et al. 2001; Nair y Reghunath 2009; Atmakuri et al. 2009; Srivastava et al. 2009; Castillo et al. 2010; Salaj et al. 2011; Ai et al. 2012; Matsumoto 2013; Li et al. 2015) o de pequeñas diferencias (Martín y González-Benito 2005; Martín et al. 2011; Kaity et al. 2008 y 2009; Zeliang et al. 2010; Mikula et al. 2011; Srivastava 2009) del material crioconservado.

Durante la aplicación de los procedimientos de crioconservación las células o tejidos se ven expuestos a condiciones extremas (por ejemplo, durante la escisión, tratamientos osmóticos, deshidratación y transición al estado vítreo) que pueden dar lugar a estreses fisiológicos y que podrían afectar a la estabilidad genética (Harding 2004; Panis y Lambardi 2006).

Esos estreses pueden dar lugar a daño oxidativo debido a que la producción excesiva de especies reactivas del oxígeno (ROS, Reactive Oxigen Species) sobrepase la capacidad antioxidante presente en las células. Los resultados de estrés oxidativo dependerán del equilibrio entre las respuestas pro y anti-oxidantes. El desequilibrio puede conducir a respuestas controladas, tales como la resistencia inducida a patógenos y un desequilibrio 
excesivo, al daño celular y la mutación, la muerte celular programada (apoptosis) y, en el extremo, a la muerte celular no programada (Casells y Curry 2001).

Las ROS son altamente reactivas y puede perturbar la actividad celular normal a través del daño a lípidos, proteínas y ácidos nucleicos (Imlay 2003; Bhattacharjee 2011). Dentro de las ROS encontramos radicales libres, como el radical superóxido $\left(\mathrm{O}_{2}{ }^{\circ}\right)$ y el radical hidroxilo $\left(\mathrm{OH}^{\circ}\right)$, y no radicales o moleculares, como el peróxido de hidrógeno $\left(\mathrm{H}_{2} \mathrm{O}_{2}\right)$ el, ozono $\left(\mathrm{O}_{3}\right)$ y el oxígeno singlete $\left({ }^{1} \mathrm{O}_{2}\right.$ ) (Gill y Tuteja 2010, Gutteridge y Halliwell 2000). Dentro de las especies reactivas del nitrógeno $(\mathrm{RON})$, el óxido nítrico puede reaccionar con el oxígeno dando lugar al dióxido de nitrógeno $\left(\mathrm{NO}_{2}{ }^{\circ}\right)$ mucho más reactivo que el NO (Gutteridge y Halliwell 2000) y también puede reaccionar con el $\mathrm{O}_{2}{ }^{--}$dando lugar al peroxinitrito (ONOO-). El ADN puede ser dañado principalmente por $\mathrm{OH}^{\bullet}$ y ${ }^{1} \mathrm{O}_{2}$. $\mathrm{El} \mathrm{OH}^{\bullet}$ es el más perjudicial, afectando a las bases púricas y pirimidínicas, así como a la desoxirribosa; el ${ }^{1} \mathrm{O}_{2}$ ataca a la guanina (Aust y Eveleigh 1999; Gill y Tujeda 2010). Los daños producidos en el ADN incluyen deleciones, mutaciones, modificaciones de bases y roturas en la cadena. Otro proceso provocado por el metabolismo secundario del daño oxidativo es la peroxidación lipídica en las membranas celulares. El malondialdehído (MDA) es un producto causado por la reacción de las ROS con ácidos grasos poliinsaturados de la membrana (Davey et al. 2005, Yamauchi et al. 2008). Es una molécula altamente reactiva y tóxica, que reacciona con las proteínas y ácidos nucleicos y provoca lesiones mutagénicas (Plastaras et al. 2000, Yamauchi et al. 2008; Dumet y Benson 2000; Esterbauer et al. 1988). La cantidad de MDA en los tejidos se correlaciona con el grado de oxidación y se puede medir fácilmente (Davey et al. 2005), como por ejemplo con el ensayo del ácido tiobarbitúrico (TBA).

Utilizando sondas fluorescentes específicas como el 2`,7`- diclorofluorescina diacetato (DCF-DA), el dihidroetidio (DHE) y el 4,5-diaminofluorescina diacetato (DAF-2 DA) se puede detectar la formación de $\mathrm{H}_{2} \mathrm{O}_{2}, \mathrm{O}_{2}{ }^{--}$y $\mathrm{NO}$, respectivamente, dentro de los tejidos observándolos bajo Microscopio Láser Confocal espectral (CLSM; Rodríguez-Serrano et al. 2006; Fink et al. 2004; Corpas et al. 2004; Kojima et al. 1998). DCF-DA es un compuesto no fluorescente que es capaz de atravesar las membranas biológicas, y una vez dentro de la célula los grupos acetato son hidrolizados por esterasas intracelulares, convirtiéndose así en un compuesto fluorescente capaz de reaccionar con el $\mathrm{H}_{2} \mathrm{O}_{2}$ (Brul et al. 1997). DHE es capaz de atravesar pasivamente las membranas celulares reacciona con el $\mathrm{O}_{2}{ }^{-}$, dando lugar a un compuesto oxidado fluorescente denominado oxietidio (Oxy-E; Fink et al. 2004). La formación de Oxy-E requiere la participación de $2 \mathrm{O}_{2}{ }^{\circ}$, con la formación de un radical libre 
de etidio $(\mathrm{E} \bullet)$ como intermediario de la reacción. La oxidación del Oxy-E es irreversible. La formación de oxietidio puede inhibirse por acción de superóxido dismutasa pero no por catalasa, además, no se forma oxietidio por adición de $\mathrm{H}_{2} \mathrm{O}_{2}$, peroxinitrito o ácido hipocloroso, lo cual demuestra la especificidad del fluorocromo por el $\mathrm{O}_{2}{ }^{--}$(Fink et al. 2004). Las diaminofluoresceínas (DAF-2 DA) no reaccionan con ROS y presentan un límite de detección para el NO de $5 \mathrm{nM}$. Este compuesto es hidrolizado por esterasas citosólicas hasta DAF-2, el cual a pH fisiológico no es fluorescente, pero si reacciona con el NO intracelular da lugar a la aparición de una forma triazólica altamente fluorescente que emite en la zona del verde (DAF-2T) (Kojima et al. 1998).

Los antioxidantes son parte del mecanismo que controla la acumulación de ROS en las plantas y disminuyen sus propiedades citotóxicas y reactivas (Bhattacharjee 2011). Entre éstos, el ácido ascórbico es el más abundante en las células vegetales encontrándose en cloroplastos, citosol, vacuolas y apoplasto; minimiza el daño producido por los radicales (al ser fácilmente oxidado) y tiene un papel esencial en la eliminación del $\mathrm{H}_{2} \mathrm{O}_{2}$ a través de la vía de Halliwell-Asada. El $\mathrm{H}_{2} \mathrm{O}_{2}$ también se elimina a través del ciclo ascorbato / glutatión (Foyer 1993). Actúa reduciendo directamente $\mathrm{al} \mathrm{O}_{2}{ }^{*}$ formando radicales libres de ascorbato o dehidroascorbato (DHA) y $\mathrm{H}_{2} \mathrm{O}_{2}$ los que son reducidos en el ciclo Halliwell-Asada (Takahama 1988). Se conoce como vitamina $\mathrm{E}$ a un grupo de sustancias que incluyen tocoferoles y tocotrienoles. $\alpha$-tocoferol (utilizado en este estudio) es un antioxidante lipofílico que protege a las membranas frente a la oxidación de los ácidos grasos poliinsaturados y neutraliza a los radicales ${ }^{1} \mathrm{O}_{2}, \mathrm{OH}^{\bullet}$ y $\mathrm{O}_{2}{ }^{*-}$ (Bhattacharjee 2011).

En el capítulo anterior se ha estudiado el efecto de los antioxidantes aplicados en un solo paso de un protocolo de crioconservación mediante encapsulación-deshidratación en dos genotipos de menta: los antioxidantes utilizados no tuvieron un efecto significativo en la recuperación, pero la vitamina E mejoraba la estabilidad en el genotipo menos estable. Uchendu y col. (2010a) estudiaron el efecto de la adición de vitamina E ( $\alpha$-tocoferol) y vitamina C (ácido ascórbico) en cuatro pasos del protocolo de vitrificación (precultivo, osmoprotección, lavado y recuperación) en ápices de Rubus. La vitamina C aumentó la recuperación de los ápices y provocó una disminución en la producción de MDA, cualquiera que fuera el paso en que se utilizaba.

Martín y González-Benito (2005) encontraron un mayor grado de variabilidad en ápices de crisantemo crioconservados por encapsulación-deshidratación que en aquellos donde se 
utilizó la vitrificación; en el estudio de cada paso del proceso, las diferencias aparecieron a partir del precultivo en 0,3 M de sacarosa (Martín et al. 2011). Según los autores, las diferencias encontradas podrían ser explicadas por el efecto del estrés osmótico, que a su vez estaría relacionado con la producción de ROS.

El objetivo del presente estudio fue evaluar la estabilidad genética de ápices del genotipo de Mentha x piperita L. que resultó más estable ('MEN 198') mediante marcadores RAPD y AFLP después de cada etapa del protocolo de crioconservación por encapsulacióndeshidratación, y el efecto de la adición de antioxidantes en la etapa de precultivo en 0,3 M sacarosa. El daño oxidativo producido después de cada paso se evaluó mediante la cuantificación de la producción de MDA y del análisis de la generación de ROS y NO mediante sondas fluorescentes y visualización con microscopía confocal, incluyendo el ácido ascórbico tanto en la etapa del precultivo en $0,3 \mathrm{M}$ sacarosa como en 0,75 M sacarosa.

\subsection{Materiales y métodos}

Para el estudio de la recuperación de los ápices y de estabilidad genética se cultivaron los ápices (o ápices encapsulados) después de cada paso del protocolo (ver Fig. 3.4). En la descripción de cada paso del protocolo se indica la letra utilizada como código de cada tipo de muestra. Para el paso "A" (ápices extraídos de los vástagos cultivados in vitro) se cultivaron segmentos nodales en medio MS durante una semana a $25^{\circ} \mathrm{C}$ (en las condiciones normales de multiplicación, ver apartado 3.2).

\subsubsection{Aclimatación de Segmentos Nodales y Precultivo de Ápices}

A partir de vástagos micropropagados del genotipo 'MEN 198' se extrajeron segmentos nodales y se precultivaron en medio MS con sacarosa al $3 \%$. Se incubaron durante 3 semanas a temperaturas alternas de $25{ }^{\circ} \mathrm{C}(\mathrm{luz}) /-1^{\circ} \mathrm{C}$ (oscuridad) con un fotoperiodo de $16 \mathrm{~h}$ y $50 \mu \mathrm{mol}$ $\mathrm{m}^{-2} \mathrm{~s}^{-1}$ PPFD. Posteriormente, con la ayuda de una lupa, se extrajeron los ápices (aprox. $2 \mathrm{~mm}$ de largo, con 1-2 pares de primordios foliares) de las yemas axilares (paso "N"). Los ápices se transfirieron a medio MS líquido suplementado con $0,3 \mathrm{M}$ sacarosa, y se cultivaron a $25^{\circ} \mathrm{C}$ durante un día, con una PPFD de aproximadamente $10 \mu \mathrm{mol} \mathrm{m}^{-2} \mathrm{~s}^{-1}$, con $16 \mathrm{~h}$ de fotoperiodo (paso "PMS"). En este paso también se cultivaron ápices en el mismo medio, pero 
suplementado con 0,43 mM ácido ascórbico ("PAA"), o sobre papel de filtro donde se había extendido $\alpha$-tocoferol (vitamina E) y colocado sobre el medio líquido (“PVE”).

\subsubsection{Crioconservación Mediante Encapsulación-Deshidratación}

Los ápices precultivados se sumergieron en una solución de alginato de sodio al $3 \%$ disuelto en medio MS líquido + 0,4 M de sacarosa. Después se succionaron junto con la solución con una pipeta, y se dispensaron gota a gota (conteniendo cada gota un ápice) en medio de encapsulación o polimerización (MS líquido $+0,4 \mathrm{M}$ de sacarosa $+100 \mathrm{mM}$ de $\mathrm{CaCl}_{2}$ ), donde las cuentas formadas se mantuvieron sumergidas durante aproximadamente media hora. Posteriormente, las cuentas se cultivaron en $50 \mathrm{~mL}$ de medio MS líquido + 0,75 M de sacarosa, y se mantuvieron en agitación a 120 rpm, durante 16-18 horas (de las cuales ocho eran horas en la oscuridad y el resto bajo una PPFD de aproximadamente $10 \mu \mathrm{mol}$ $\mathrm{m}^{-2} \mathrm{~s}^{-1}$ ), a $25^{\circ} \mathrm{C}$ (pasos "SMS", "SAA" o "SVE", según el medio utilizado en el paso "P"). Después de ese período se retiraron las cuentas, se quitó superficialmente el exceso de líquido con un papel de filtro estéril, y se colocaron en placas Petri abiertas para deshidratarlas durante 5 horas en el flujo de aire de una cabina de flujo laminar (pasos "DMS" "DAA" o "DVE", según el medio utilizado en el paso "P"), hasta $22 \pm 1 \%$ de contenido de agua sobre peso fresco (Teixeira et al. 2014). Las cuentas se introdujeron en crioviales de $2 \mathrm{ml}$ (cinco cuentas por criovial) y se sumergieron rápidamente en nitrógeno líquido (NL), donde se mantuvieron durante al menos un día. El calentamiento de los crioviales se llevó a cabo en un baño de agua a $40{ }^{\circ} \mathrm{C}$, durante aproximadamente 2 minutos. Las cuentas fueron extraídas del criovial y cultivadas en placas Petri con medio de recuperación (pasos "CrMS", "CrAA" o “CrVE”, según el medio utilizado en el paso "P”).

\subsubsection{Recuperación}

Los ápices/cuentas obtenidos después de cada paso del protocolo se cultivaron en medio semisólido MS con sacarosa al $3 \%$, suplementado con $0,5 \mathrm{mgL}^{-1}$ 6-dimetilalilamino-purina y 0,1 $\mathrm{mgL}^{-1}$ ácido $\alpha$-naftalen-acético (Senula et al. 2007). Se utilizaron 6 réplicas por paso (5 ápices/cuentas por réplica). Cada réplica fue cultivada en una placa Petri de $6 \mathrm{~cm}$ de diámetro con $10 \mathrm{~mL}$ de medio. Los cultivos se incubaron las primeras $24 \mathrm{~h}$ bajo oscuridad, seguido de 20 días con aproximadamente $10 \mu \mathrm{mol} \mathrm{m} \mathrm{m}^{-2} \mathrm{~s}^{-1} \mathrm{PPFD}$, y después fueron transferidos a $50 \mu \mathrm{mol}$ 
$\mathrm{m}^{-2} \mathrm{~s}^{-1}$, siempre con un fotoperiodo de $16 \mathrm{~h}$, y a una temperatura de $25^{\circ} \mathrm{C}$. A las cuatro semanas de cultivo el material vegetal vivo se transfirió a frascos de cristal con medio de cultivo MS, sin reguladores de crecimiento, y se mantuvieron en las mismas condiciones de luz y temperatura durante cuatro semanas más.

\subsubsection{Extracción de ADN}

Para la extracción de ADN se tomaron muestras de los explantos supervivientes después de las 8 semanas de cultivo. Las muestras se obtuvieron a partir de hojas ("L”) de los vástagos regenerados. Las muestras se cortaron en trozos pequeños y se introdujeron en tubos eppendorf de 1,5 ml junto a cuatro bolitas de vidrio (para la trituración con el Tissulyser), y se almacenaron a $-80^{\circ} \mathrm{C}$ hasta el momento de la extracción. La extracción se realizó de acuerdo al protocolo descrito por Gawel y Jarret (1991) con pequeñas modificaciones. Las muestras fueron trituradas en un molino (Tissulyser II ®) a una frecuencia de $25 \mathrm{rps}$ en dos ciclos de 30 s cada uno. Se utilizó un tampón de extracción CTAB (cetyl trimethylamonio bromuro) [2 \% CTAB (p/v), 100 mM tris $\mathrm{HCl}(\mathrm{pH} \mathrm{8,0),} \mathrm{1,4} \mathrm{M} \mathrm{NaCl,} 20$ mM EDTA, 1\% PVP (p/v), $36 \mathrm{mM}$ $\mathrm{NaHSO}_{3}$ y $0,2 \% \beta$-mercaptoetanol v/v]. Una vez pulverizado, al material vegetal se le añadieron $700 \mu \mathrm{L}$ del tampón de extracción, se agitó en vortex y se incubó en un baño de agua caliente a $65^{\circ} \mathrm{C}$ por $1 \mathrm{~h}$ (removiendo los tubos 3-4 veces durante la hora). Se añadieron $600 \mu \mathrm{l}$ de cloroformo: alcohol isoamílico $(24: 1 \mathrm{v} / \mathrm{v})$, almacenado a $4{ }^{\circ} \mathrm{C}$, y se mezcló por inversión durante 5 min a temperatura ambiente. Se centrifugó a 12.000 rpm durante 7 min. Se tomaron $500 \mu \mathrm{L}$ del sobrenadante y se transfirieron a un tubo limpio al que se añadieron $500 \mu \mathrm{L}$ de isopropanol helado (almacenado a $-20{ }^{\circ} \mathrm{C}$ ). Se mantuvo en incubación durante una noche a $-20{ }^{\circ} \mathrm{C}$ y posteriormente se centrifugó a $12.000 \mathrm{rpm}$ por $7 \mathrm{~min}$, eliminando el isopropanol. Para lavar el pellet de ADN se añadieron $300 \mu \mathrm{L}$ de etanol al $70 \%$ a temperatura ambiente, y luego se centrifugó a $12.000 \mathrm{rpm}$ por $7 \mathrm{~min}$, se eliminó el etanol y repitió el lavado una segunda vez. Posteriormente se dejaron los tubos secándose. Finalmente, se resuspendió el pellet de ADN de cada muestra en $100 \mu \mathrm{L}$ de agua destilada estéril. Todas las muestras fueron tratadas con RNasa para eliminar el ARN presente. Las muestras fueron conservadas a $-20^{\circ} \mathrm{C}$. La concentración de ADN se estimó por comparación con patrones de ADN en un gel de agarosa al $0,8 \%(\mathrm{p} / \mathrm{v})$. 


\subsubsection{Marcadores Moleculares RAPDs}

Los patrones RAPDs se generaron utilizando ocho cebadores arbitrarios de Operon Technologies: OPA-11 (5 'CAATCGCCGT 3'), OPE-19 (5 'ACGGCGTATG 3'), OPF-1 (5 'ACGGATCCTG 3'), OPF-3 (5 'CCTGATCACC 3'), OPF-10 (5 'GGAAGCTTGG 3'), OPO-7 (5 'CAGCACTGAC 3'), OPO-10 (5 'TCAGAGCGCC 3') y OPO-20 (5 'ACACACGCTG 3'). Las amplificaciones de ADN se realizaron en un volumen final de $25 \mu \mathrm{L}$, que contenía $10 \mathrm{ng}$ de ADN total (aproximadamente), 0,4 $\mathrm{M}$ del cebador, 0,2 $\mathrm{mM}$ de cada dNTP, 1,5 $\mathrm{mM}$ de $\mathrm{MgCl}_{2}$ y $1 \mathrm{U}$ de la Taq ADN polimerasa, en el tampón proporcionado por el fabricante de la enzima (Biotools). Las amplificaciones se realizaron en un termociclador (Eppendorf), utilizando un programa consistente en un ciclo de 1 min a $94{ }^{\circ} \mathrm{C}$, seguido por 35 ciclos de $45 \mathrm{~s}$ a $92{ }^{\circ} \mathrm{C}, 1$ min a $37{ }^{\circ} \mathrm{C}$ y $2 \min$ a $72{ }^{\circ} \mathrm{C}$, y un ciclo final de 3 min a $72{ }^{\circ} \mathrm{C}$. Los productos de amplificación se separaron en gel de agarosa al 1,5\% (p/v) mediante electroforesis (110 V) utilizando tampón $1 \times$ TBE [100 mM tris $\mathrm{HCl}, 100 \mathrm{mM}$ ac. Bórico, 2mM M EDTA $(\mathrm{Na})_{2}(\mathrm{pH}$ 8,0),] (Sambrook et al. 1989). Tras 2,5 h de electroforesis, los geles fueron teñidos con bromuro de etidio $\left(0,5 \mu \mathrm{g} \mathrm{mL}^{-1}\right)$ durante 7-10 minutos y se fotografiaron bajo luz UV. El tamaño de los fragmentos de ADN amplificados se estimó mediante referencia con una escala de ADN de tamaños conocidos (escalera de 100 pares de base, GE Healthcare). Todas las amplificaciones se repitieron al menos dos veces, y sólo las bandas reproducibles se consideraron para el análisis.

\subsubsection{Marcadores moleculares AFLPs}

El análisis AFLP se realizó de acuerdo a lo descrito por Vos y col. (1995). El ADN genómico se digirió con dos enzimas de restricción: Eco RI y Mse I. Se utilizaron 12,5 U de Eco RI, 6 U de Mse I (New England Biolabs) y 500 ng de ADN genómico en tampón RL10 x

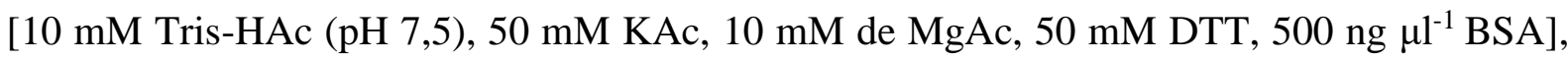
con un volumen final de $35 \mu \mathrm{L}$. La reacción se mantuvo durante 3 horas a $37{ }^{\circ} \mathrm{C}$. Dos adaptadores diferentes, diseñados para evitar la reconstrucción de estos sitios de restricción y para disponer de un molde de secuencia conocida, uno para el extremo cohesivo Eco RI y otro para el extremo cohesivo Mse I, se ligaron a los fragmentos de ADN mediante la adición de 5 $\mu \mathrm{L}$ de una solución de ligación que contenía 5 pmol del adaptador Eco RI, 50 pmol del adaptador Mse I, $10 \mathrm{mM}$ de ATP y 1,2 U de T4 ADN ligasa (Boehringer) en el tampón RL10x. La ligación se incubó durante $3 \mathrm{~h}$ a $37{ }^{\circ} \mathrm{C}$ y luego durante una noche a $4{ }^{\circ} \mathrm{C}$. Los 
fragmentos de ADN digeridos y ligados se diluyeron cinco veces para ser utilizados en la primera amplificación. La reacción PCR se realizó con un volumen final de $20 \mu \mathrm{L}$ que contenían $30 \mathrm{ng}$ de cada cebador Eco $R I+$ A y Mse I + C, 0,2 mM de cada dNTP, 1,5 mM de $\mathrm{MgCl}_{2}, 0,4 \mathrm{U}$ de la Taq ADN polimerasa (Biotaq, Bioline) y $3 \mu \mathrm{L}$ de los fragmentos diluidos en tampón de PCR 10 x proporcionado por el fabricante (Bioline). La amplificación consistió en 28 ciclos de $30 \mathrm{~s}$ a $94{ }^{\circ} \mathrm{C}, 1 \min$ a $60{ }^{\circ} \mathrm{C}$ y 1 min a $72{ }^{\circ} \mathrm{C}$, y se llevó a cabo en un termociclador MJ. Dos microlitros del producto de amplificación $+8 \mu \mathrm{L}$ de agua destilada estéril $+2 \mu \mathrm{L}$ de tampón de carga se corrieron en un gel de agarosa al 0,7\% durante 10 min para determinar la intensidad de la amplificación y así corregir la dilución de las diferentes muestras. Los fragmentos preamplificados se diluyeron diez veces para ser utilizado como material de partida para la amplificación selectiva. En esta amplificación, sólo el cebador Eco $R I$ se marcó con el fluorocromo FAM. Ambos cebadores, Eco RI y Mse I, contienen las mismas secuencias utilizadas en la preamplificación, pero con tres nucleótidos selectivos en el extremo 3'. Para la amplificación selectiva las diferentes combinaciones de cebadores utilizados fueron nombradas de esta forma: A2 (Eco ACG/Mse CCA); A3 (ACA/CAG); C1 (ACC/ACC); C2 (ACC/CAG); C5 (ACA/CAT); C6 (ACA/CCA); C7 (AGT/CAT) y C8 (AGT/CCA). La reacción PCR se realizó en un volumen final de $20 \mu \mathrm{L}$ que contenía 6 ng de cebador marcado Eco RI, $30 \mathrm{ng}$ del cebador Mse I, 0,1 mM de cada dNTP, 1,5 mM de $\mathrm{MgCl}_{2}$, $0,4 \mathrm{U}$ de la Taq ADN polimerasa, y $3 \mu \mathrm{L}$ de $\mathrm{ADN}$ preamplificado y diluido en $10 \mathrm{x}$ del tampón de PCR proporcionado por el fabricante (Bioline). La amplificación selectiva se realizó con 1 ciclo de $30 \mathrm{~s}$ a $94{ }^{\circ} \mathrm{C}, 30 \mathrm{~s}$ a $65^{\circ} \mathrm{C}, 1$ min a $72^{\circ} \mathrm{C}$ seguido de 12 ciclos en los que la temperatura de recorrido disminuía $0,7^{\circ} \mathrm{C}$ por ciclo, seguido por 23 ciclos de 1 min a $94{ }^{\circ} \mathrm{C}$, $30 \mathrm{~s}$ a $56^{\circ} \mathrm{C}$ y 1 min a $72{ }^{\circ} \mathrm{C}$. Los productos de amplificación se analizaron en un secuenciador automatizado ABI3730 por la empresa SECUGEN S.L. (Madrid, España). Los electroferogramas obtenidos se analizaron mediante el programa GeneMarker v1.90 (SoftGenetics, LLC).

\subsubsection{Medición ROS y NO Mediante Fluorocromos}

Se midió la generación de ROS y óxido nítrico (NO) producidos durante el proceso de crioconservación, mediante fluorocromos específicos y observando las muestras bajo microscopía confocal (CLMS). Este estudio se llevó a cabo en el Centro de Investigaciones Biológicas-CSIC (CIB) siguiendo el protocolo descrito por Rodríguez-Serrano et al (2009). 
El análisis se realizó en los ápices de menta inmediatamente después de diversos pasos del protocolo, y eran trasladados desde nuestro laboratorio hasta el laboratorio del CIB en las soluciones utilizadas en las correspondientes etapas de crioconservación por encapsulacióndeshidratación. Los ápices estudiados después de la inmersión en NL se cultivaron durante un día en medio de recuperación, y se extrajeron de la cuenta (paso "Cr"). Los ápices fueron seccionados de forma longitudinal $(20-40 \mu \mathrm{m})$, mediante el uso de un Vibratomo (Leica VT 1000 ST), e incubados rápidamente en las soluciones correspondientes para evitar la oxidación o volatilización de los compuestos.

Para detectar el anión $\mathrm{O}_{2}{ }^{\bullet-}$ se utilizó el dihidroetidio (DHE). Para comprobar la especificad del fluorocromo por el anión superóxido, las muestras se incubaron con tetrametilpiperidina (TMP), secuestrador de $\mathrm{O}_{2}{ }^{--}$(control negativo). Los cortes se incubaron con o sin TMP $1 \mathrm{mM}$ durante $1 \mathrm{~h}$ a temperatura ambiente, posteriormente se incubaron en una solución con DHE 10 $\mu \mathrm{M}$ (Fluka) preparado en tampón Tris- $\mathrm{HCl} 10 \mathrm{mM}(\mathrm{pH} 7,4)$, durante $30 \mathrm{~min}$ a $37{ }^{\circ} \mathrm{C}$ y en oscuridad. Parte de las muestras se incubaron sin el secuestrador. Por último, las muestras se lavaron durante 30 min con el mismo tampón.

Para detectar el $\mathrm{H}_{2} \mathrm{O}_{2}$, se utilizó 2`7`- diclorofluorescina diacetato (DCF-DA). Como control de la especificidad del fluorocromo (control negativo) las muestras se incubaron con ascorbato, secuestrador de $\mathrm{H}_{2} \mathrm{O}_{2}$. Los cortes se incubaron con o sin ascorbato $1 \mathrm{mM}$ durante $1 \mathrm{~h}$ a temperatura ambiente, y posteriormente se incubaron en una solución con DCF-DA $25 \mu \mathrm{M}$ preparada en tampón Tris- $\mathrm{HCl} 10 \mathrm{mM}(\mathrm{pH} 7,4)$, durante $30 \mathrm{~min}$ a $37{ }^{\circ} \mathrm{C}$ y en oscuridad. Parte de las muestras se incubaron sin el secuestrador. Por último, las muestras se lavaron durante 30 min con el mismo tampón.

Para la detección del NO se siguió el método descrito por Kojima y col. (1998), que consistió en la utilización de 4,5-diaminofluorescina diacetato (DAF-2 DA) como marcador de óxido nítrico. Para comprobar la especificad del fluorocromo, las muestras se incubaron con, el 2-4-carboxyfenil-4,4,5,5-tetrametilmidazolina-1oxil-3-oxido (cPTIO), secuestrador de NO (Corpas et al. 2006). De igual forma que lo descrito anteriormente, los cortes se incubaron con o sin $200 \mathrm{uM}$ de cPTIO durante $1 \mathrm{~h}$ a temperatura ambiente, posteriormente, se incubaron en una solución con $10 \mu \mathrm{M}$ DAF-2DA (Calbiochem) preparada en tampón Tris-HCl $10 \mathrm{mM}$

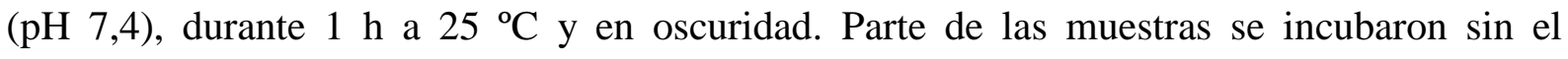
secuestrador. Por último, las muestras se lavaron durante 30 min con el mismo tampón.

Finalmente, los ápices se montaron en portaobjetos junto a una gota de glicerol al $50 \%$ y 
se observaron en el Microscopio Láser Confocal espectral (CLSM) Leica TCS SP5, utilizando las longitudes de onda de excitación y emisión correspondientes a cada fluorocromo (Tabla $6.1)$.

Tabla 6.1. Longitudes de onda de excitación y emisión de flurocromos utilizados.

\begin{tabular}{ccc}
\hline Fluorocromo & $\boldsymbol{\lambda}$ de Excitación (nm) & $\boldsymbol{\lambda}$ de Emisión $(\mathbf{n m})$ \\
\hline DHE & 488 & 520 \\
DFC-DA & 485 & 530 \\
DAF-2 DA & 495 & 515 \\
\hline
\end{tabular}

Se estudiaron los pasos del protocolo "N", "P", "S" y "Cr"; este último después de un día de cultivo (ver apartados 6.2.1 y 6.2.3, y Fig. 3.5). También se estudió el efecto de la incorporación en los pasos "P" o "S" de 0,43 $\mathrm{mM}$ ácido ascórbico ("Pa" y "Sa", respectivamente). Se realizaron 3-5 repeticiones por cada paso, y 2-3 repeticiones para las muestras con secuestrador.

\subsubsection{Cuantificación de Malondialdehído}

La metodología utilizada es una modificación de los protocolos descritos por Davey y col. (2005) y Uchendu y col. (2010a). El análisis de las muestras fue realizado por el Servicio de Análisis de la Universidad Complutense de Madrid mediante HPLC (High Performance Liquid Chromatography, cromatografía líquida de alta eficacia) de fase inversa.

Para la extracción de MDA se utilizaron 20-40 mg de material vegetal (40 ápices) por repetición (3-5 repeticiones por paso del protocolo estudiado). Los ápices del genotipo 'MEN 198' se extrajeron inmediatamente después de aplicar el tratamiento correspondiente al paso del protocolo. Las muestras del paso "A" (5-6 hojas procedentes de cultivo in vitro) se extrajeron de forma similar a como se hicieron para el estudio de la estabilidad genética (ver apartado 6.2). Se lavaron los ápices/hojas con agua destilada, se secaron con papel filtro y se introdujeron en NL dentro de un eppendorf de $2 \mathrm{~mL}$ con cuatro cuentas de vidrio (dos grandes y dos pequeñas). Las muestras fueron trituradas en un molino (Tissulyser II ®) a una frecuencia de $25 \mathrm{rps}$ durante $30 \mathrm{~s}$, utilizando soportes enfriados a $-80^{\circ} \mathrm{C}$. Se añadieron $150 \mu \mathrm{L}$ de tampón de extracción de ácido metafosfórico al $5 \%(\mathrm{p} / \mathrm{v})$ y $15 \mu \mathrm{L}$ de hidroxitolueno 
butilado al $2 \%(\mathrm{p} / \mathrm{v})$ en metanol. Luego se agitó en vortex y se centrifugó a 12.500 rpm durante $5 \mathrm{~min}$. Se tomaron $100 \mu \mathrm{L}$ del sobrenadante y se le añadió $50 \mu \mathrm{L}$ de ácido tiobarbitúrico (TBA) al $1 \%$ en $\mathrm{NaOH} 50 \mathrm{mM}$ y se agitó. Después se añadieron $50 \mu \mathrm{L}$ de $\mathrm{HCl}$ $25 \%(\mathrm{v} / \mathrm{v}) \mathrm{pH}$ 1,0. Tras agitar, la reacción se incubó en un baño caliente a $95{ }^{\circ} \mathrm{C}$ durante 30 min. Al aducto MDA(TBA)2 formado se le añadió $150 \mu \mathrm{L}$ de n-butanol y se agitó. Posteriormente se centrifugó a $12.500 \mathrm{rpm}$ durante 7 min y se recogió el sobrenadante. Se inyectaron alícuotas de $10 \mu \mathrm{L}$ del sobrenadante en un sistema de HPLC Varian L929, con un autosampler. Se utilizó una columna de fase inversa C-18 de $250 \mathrm{~mm}$ a $40{ }^{\circ} \mathrm{C}$. El aducto $\mathrm{MDA}(\mathrm{TBA})_{2}$ se eluyó usando una fase móvil isocrática que consistía en $\mathrm{K}_{2} \mathrm{HPO}_{4}(50 \mathrm{mM}) \mathrm{pH}$ $=6,8: \mathrm{MeOH}(65 \%: 35 \%)$. El flujo fue de $1 \mathrm{~mL} \mathrm{~min}^{-1}$. El MDA(TBA) 2 se detectó mediante fluorescencia a una excitación de $515 \mathrm{~nm}$ y emisión de $553 \mathrm{~nm}$. La cuantificación de MDA se realizó utilizando un estándar externo de 1, 1, 3, 3-tetraetoxipropano (Sigma) preparado con el mismo método que las muestras.

\subsubsection{Determinación de la Capacidad Antioxidante Mediante el Método ABTS}

Se estudió el contenido de antioxidantes totales de los dos genotipos de menta estudiados en esta tesis ('MEN 186' y 'MEN 198'), tanto de material procedente de cultivo in vitro (ver apartado 3.2) como de plantas procedentes de cultivo in vitro, las que fuero aclimatadas y cultivadas en maceta en un invernadero; se utilizaron tres repeticiones biológicas por tipo de muestra. El estudio se realizó siguiendo el protocolo de Johnston y col. (2007) y Re y col. (1999). Las mediciones se realizaron en un espectrofotómetro BioMate 3S (Thermo) y se utilizó Trolox (ácido 6-hidroxi-2,5,7,8- tetrametilcromo-2-ácido carboxílico, 97 \%, Aldrich) como antioxidante de referencia.

Para la extracción se utilizó un tampón fosfato salino $\left(50 \mathrm{mM}, \mathrm{pH}\right.$ 7) utilizando $\mathrm{KH}_{2} \mathrm{PO}_{4}$ y $\mathrm{K}_{2} \mathrm{HPO}_{4}$, suplementado con $1 \mathrm{mM} \mathrm{Na} 2 \mathrm{EDTA}, 1 \mathrm{mM} \mathrm{CaCl}_{2}$, y $1 \mathrm{mM} \mathrm{KCl}$. Se pesaron $200 \mathrm{mg}$ de material vegetal (hojas) y se molieron en frío en un mortero con NL. En las muestras en las que se utilizó polivinilpirrolidona (PVP) para evitar la interferencia de compuestos fenólicos en el análisis, se agregaron $200 \mathrm{mg}$ de PVP a las hojas, antes de molerlas con NL. La muestra se traspasó a un tubo eppendorf de $2 \mathrm{~mL}$, enfriado previamente en NL y se añadió $1 \mathrm{~mL}$ del tampón de extracción (mantenido a $4^{\circ} \mathrm{C}$ ) y la reacción se incubó durante 20 min en hielo. Las muestras se agitaron tres veces en vortex a intervalos de 5 minutos. El homogenizado se 
centrifugó a $12.000 \mathrm{rpm}$ por $10 \mathrm{~min} \mathrm{a} 4{ }^{\circ} \mathrm{C}$, se extrajo el sobrenadante y se almacenó en hielo. La extracción se realizó el mismo día del análisis.

Para el ensayo de capacidad antioxidante, el ABTS [ácido 2,2'-azinobis-(3etilbenzotiazolina-6-sulfónico), Sigma] se disolvió en agua grado ultra puro (Sigma) para dar una concentración final de $7 \mathrm{mM}$. El catión radical ABTS $\left(\mathrm{ABTS}^{\bullet+}\right)$ se produjo al reaccionar la solución de ABTS con una solución de persulfato de potasio a una concentración final de 2,45 mM. Se mantuvo en incubación en oscuridad a temperatura ambiente durante al menos 12-16 h. Una vez formado el radical $\mathrm{ABTS}^{\bullet+}$ se diluyó con tampón fosfato salino $5 \mathrm{mM}$ (PBS, pH 7,4), para obtener un valor de absorbancia de 0,7 $\pm 0,1$ a $734 \mathrm{~nm}$. Para los estándares de 0-1500 $\mu \mathrm{M}$ de Trolox (Aldrich) se hizo la dilución en PBS y se almacenaron a $-20{ }^{\circ} \mathrm{C}$ hasta su utilización. Para la estandarización del punto de partida de todos los ensayos y los estándares de Trolox, se añadió un $1 \mathrm{~mL}$ de solución de $\mathrm{ABTS}^{\bullet+}$ en la cubeta del espectrofotómetro y se registró la absorbancia a $734 \mathrm{~nm}$ para el valor de 0 min. Rápidamente se añadieron $10 \mu \mathrm{l}$ de muestra o solución estándar de Trolox, se mezcló invirtiendo tres veces la cubeta y se midió la absorbancia a $734 \mathrm{~nm}$ después de 2 min de realizar la mezcla. Se calculó la variación de la absorbancia (entre 0 y 2 min) y se expresó como $\mu$ mol equivalentes de Trolox sobre g de peso fresco de la muestra. La equivalencia en Trolox después de 2 min da una indicación del estado antioxidante total de barrido lento (van den Berg et al. 2000).

\subsubsection{Análisis de Datos}

Se evaluaron los resultados de porcentaje de supervivencia (evidencia de estructuras verdes, yemas o callos) y de recuperación (desarrollo del vástago) a las 4 y 8 semanas de cultivo. Se utilizaron seis réplicas por paso del protocolo/tratamiento estudiado. Antes de realizar el análisis de varianza, los datos se transformaron utilizando la función arcoseno. Para la comparación de medias se utilizó el test de comparación múltiple de Duncan $(\alpha=0,05)$. Para el análisis de porcentaje de formación de callo se utilizó una regresión logística para datos binarios y se llevó a cabo una comparación por parejas según LSD con un intervalo de confianza del $95 \%$ (Modelos Lineales Generalizados). En todos los casos el programa estadístico utilizado fue IBM SPSS Statistics 20.

Los fragmentos amplificados a partir de RAPD y AFLP fueron considerados, de forma independiente para cada técnica, como presentes (1) o ausentes (0). A partir de estos datos se construyeron matrices de similitud utilizando el coeficiente de Jaccard (Jaccard 1908): S (ij) = 
$\mathrm{a} /(\mathrm{a}+\mathrm{b}+\mathrm{c})$; donde a es el número de fragmentos de ADN polimórficos comunes a ambos individuos, b es el número de fragmentos presentes en i y ausente en $\mathrm{j}$, y c es el número de fragmentos presentes en j y ausente en i. La matriz resultante se sometió a un análisis de agrupamiento de pares no ponderado (UPGMA) y el dendrograma se construyó a partir de los resultados de la agrupación con el programa TREE. Estos análisis se realizaron con la versión del programa informático NTSYS-PC 1.80 (Rohlf 1992). Los datos de porcentaje de muestras estables se analizaron mediante una regresión logística para datos binarios y se llevó a cabo una comparación por parejas según LSD con un intervalo de confianza del $95 \%$.

Los datos de cuantificación de MDA y de $\mu$ mol equivalentes de Trolox se analizaron mediante un análisis de varianza y las medias se compararon mediante el test de Duncan, utilizando el programa IBM SPSS Statistics 20.

\subsection{Resultados}

\subsubsection{Recuperación de los Ápices}

Se tomaron datos de la recuperación y supervivencia de los ápices a las 4 y 8 semanas de cultivo después de ser sometidos a los distintos pasos del protocolo (Fig. 6.1). A las 4 semanas de cultivo la supervivencia descendía después de la desecación y enfriamiento en NL; se encontró una diferencia significativa respecto a los ápices procedentes del cultivo in vitro (paso "A") en los ápices tratados con ácido ascórbico y crioconservados ("CrAA"; Fig. 6.1 A). Esa reducción en la respuesta a partir del paso de desecación era más pronunciada en la recuperación. A las 8 semanas de cultivo la respuesta después de los distintos pasos del protocolo seguía el mismo patrón que a las 4 semanas (descenso después de la desecación y de la crioconservación) a pesar de que la recuperación fue algo superior que a las 4 semanas. Es decir, que tanto a las 4 como a las 8 semanas de cultivo se observaba que a partir de la etapa "S" la regeneración comienza a verse afectada, produciéndose una disminución progresiva a medida que se avanza en el protocolo de crioconservación (Fig. 6.1).

Comparando los resultados de los ápices después de la desecación y de la crioconservación, en función de las sustancias antioxidantes utilizadas en el paso "P", solo se observó una mayor recuperación $(84 \%)$ de los ápices que había sido precultivados en 
vitamina $\mathrm{E}$ en los cultivados después de la desecación, especialmente después de 4 semanas de cultivo. Los otros dos tratamientos resultaron en porcentajes de recuperación del 53 y $58 \%$ (para "DMS" y "DAA", respectivamente). En el caso de aquellos ápices que fueron crioconservados, la regeneración a las 8 semanas muestra valores similares (aproximadamente $52 \%)$ en los tres tratamientos ensayados, sin que se encuentren diferencias significativas entre ellos. Sin embargo, el uso de ácido ascórbico y vitamina E disminuyó la formación de callo en todas las etapas del procedimiento, llegando al $0 \%$ en el paso " $\mathrm{S}$ " y siendo significativamente diferente en el tratamiento de los ápices crioconservados "CrAA" (Tabla $6.2)$.

Tabla 6.2. Formación de callo después del paso del protocolo " $\mathrm{S}$ " (cuentas cultivadas en MS 0,75 M sacarosa), "D" (cuentas deshidratadas) y "Cr" (cuentas crioconservadas) a las 8 semanas de recuperación de los ápices. Tratamientos: "MS": control sin adición de antioxidantes; "AA" y "VE": adición de ácido ascórbico y vitamina E, respectivamente, aplicados en la etapa "P" del protocolo. Dentro de un mismo paso, los porcentajes con la misma letra no son significativamente diferentes entre sí de acuerdo a la comparación por pares por LSD $(\alpha=0,05)$.

\begin{tabular}{cccc}
\hline Etapa/Tratamiento & $\mathrm{N}^{\circ}$ ápices & $\mathrm{N}^{\mathbf{0}}$ callos & $\%$ callo \\
\hline SMS & 28 & 2 & 7,1 \\
SAA & 28 & 0 & 0 \\
SVE & 30 & 0 & 0 \\
\hline DMS & 29 & 7 & 24,1 \\
DAA & 29 & 3 & 10,3 \\
DVE & 25 & 2 & 8,0 \\
\hline CrMS & 24 & 5 & $20,8 \mathrm{a}$ \\
CrAA & 25 & 0 & $0,0 \mathrm{~b}$ \\
CrVE & 29 & 4 & $13,8 \mathrm{a}$ \\
\hline
\end{tabular}




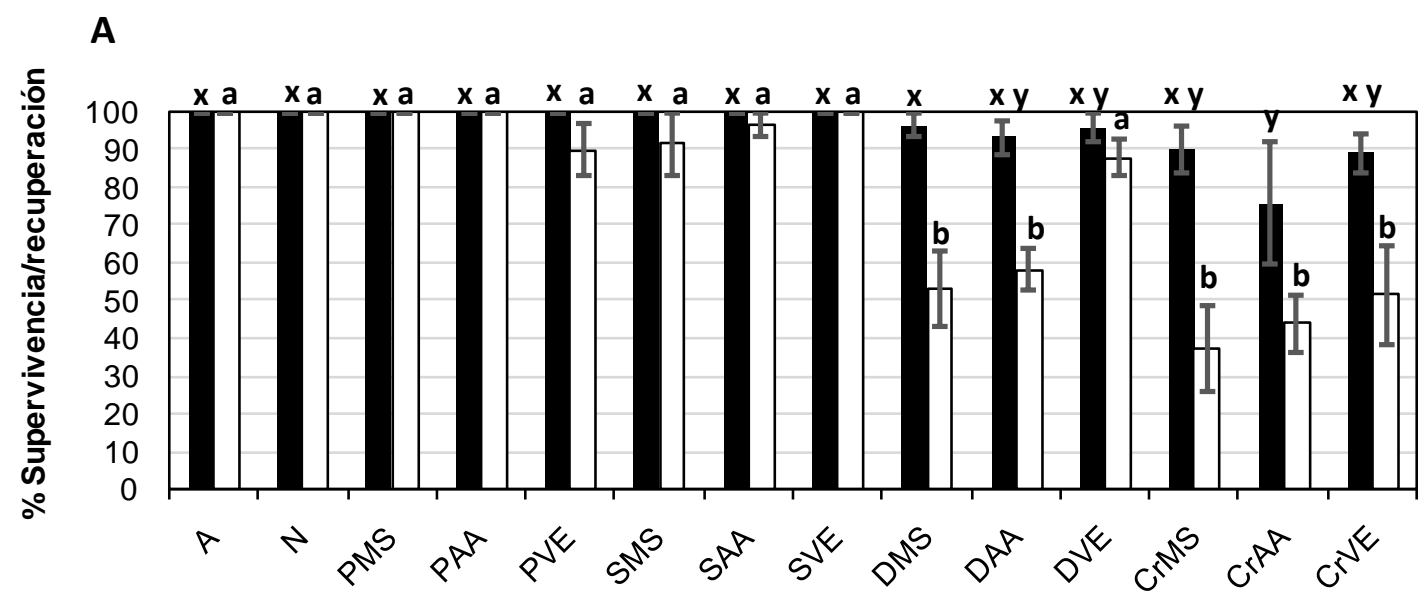

Pasos y tratamientos

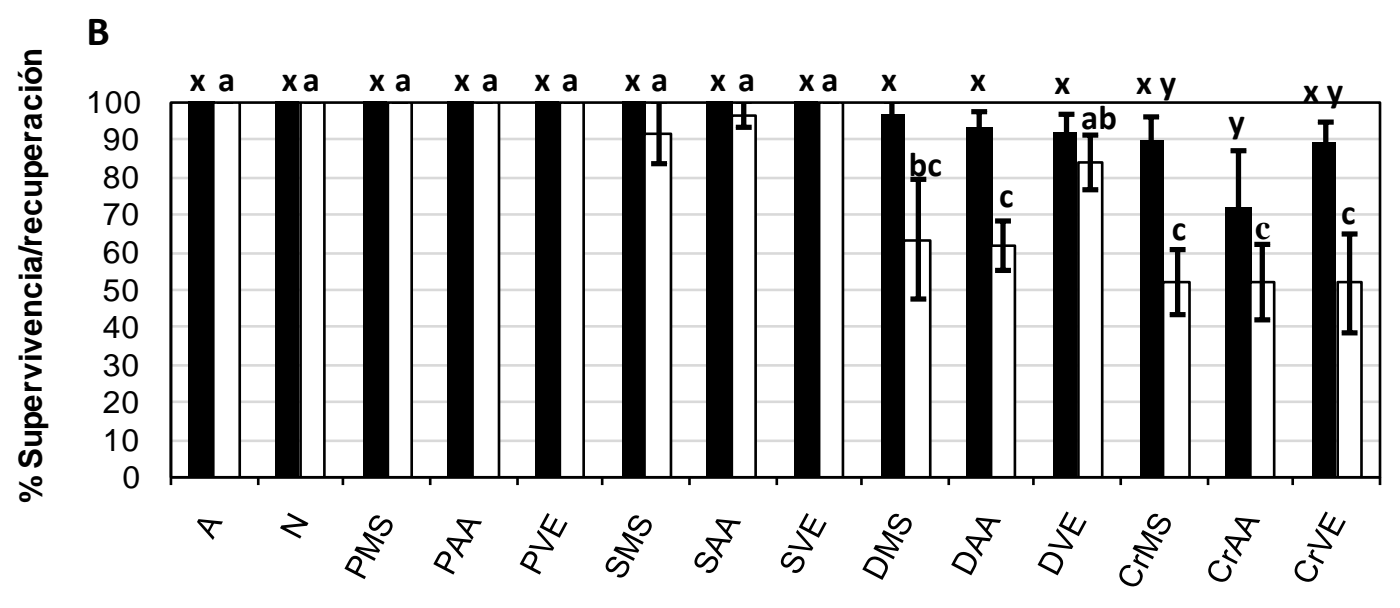

Pasos y Tratamientos

Figura 6.1. Porcentajes de supervivencia y regeneración de ápices de menta del genotipo 'MEN 198' obtenidos después de un periodo de 4 (A) y 8 semanas (B) de cultivo, sometidos a diversos pasos del protocolo de encapsulación-deshidratación. Pasos "A": control, ápices provenientes de cultivo in vitro; "N": precultivo y aclimatación de los segmentos; "P": precultivo de ápices; "S": cultivo de los ápices encapsulados; "D": deshidratación de las cuentas y "Cr": enfriamiento en nitrógeno líquido. Tratamientos: "MS": control sin adición de antioxidantes; "AA" y "VE": adición de ácido ascórbico y vitamina E, respectivamente, aplicados en la etapa "P" del protocolo. Barras: error estándar. Medias con la misma letra (x, y para supervivencia; a, b, c para recuperación) no fueron significativamente diferentes de acuerdo con el test de Duncan $(\alpha=0,05)$. 


\subsubsection{Marcadores RAPDs}

Se llevó a cabo el estudio de la estabilidad genética con el material recuperado a las 8 semanas de cultivo. Los ocho cebadores RAPD utilizados produjeron 89 bandas para las 86 muestras estudiadas, con un tamaño que va de 2.500 pb a 300 pb (Fig. 6.2). Cincuenta y ocho de los marcadores analizados resultaron monomórficos, siendo por lo tanto $34,8 \%$ polimórficos.

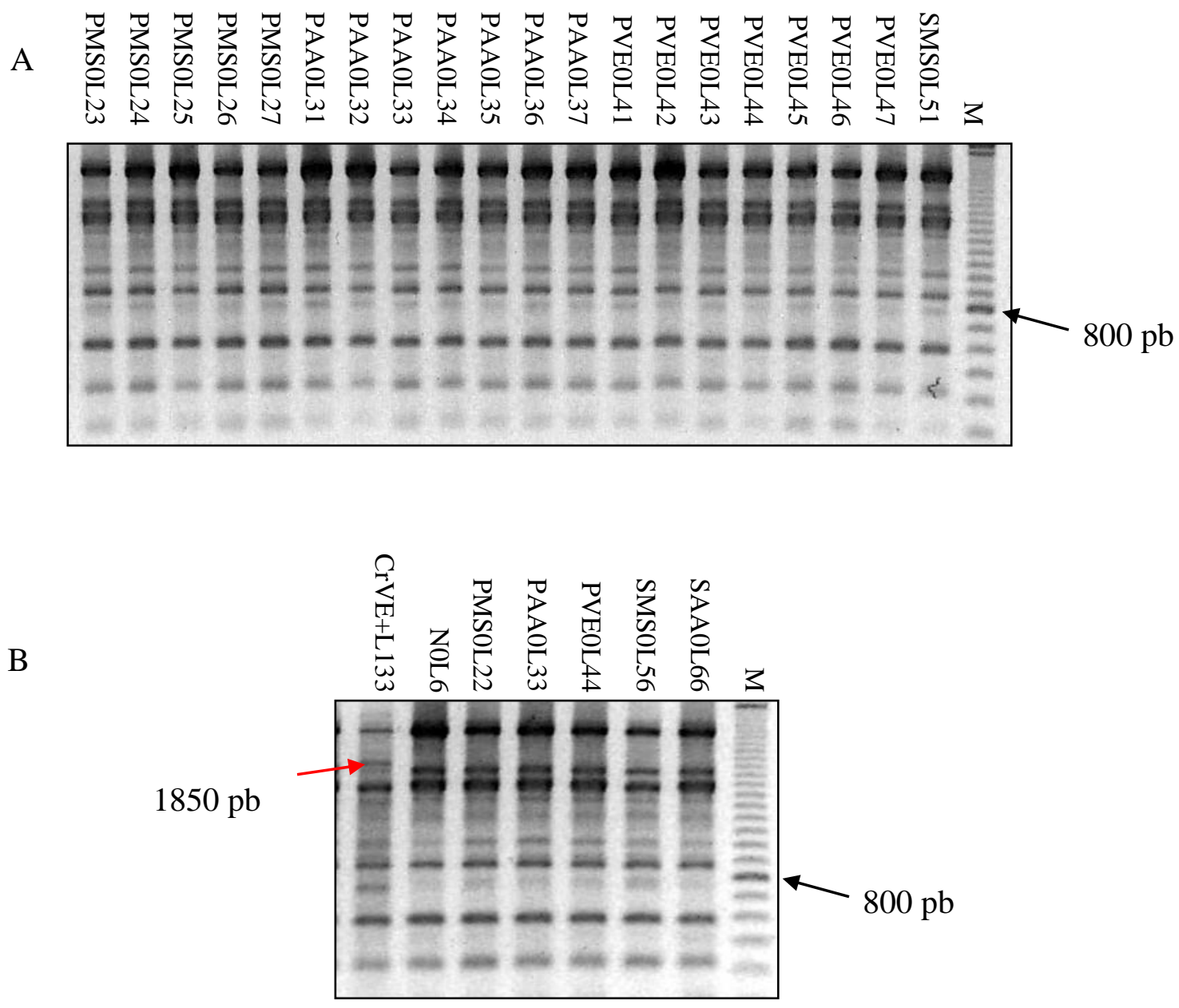

Figura 6.2. Patrón de marcadores RAPD, generado por el cebador OPO-10, de muestras de ápices de menta del genotipo 'MEN 198' obtenidas en distintos pasos del protocolo de crioconservación por encapsulación-deshidratación. " $\mathrm{M}$ " corresponde a un marcador en escalera de 100 pares de bases (pb). A) Muestras con patrón estable. B) La flecha de color rojo muestra una banda de 1850 pb nueva en la muestra "CrVE+L133". 
En el dendrograma generado (Fig. 6.3) se observa un agrupamiento de 75 muestras con exactamente el mismo patrón de bandas, lo que supone el $86,1 \%$ del total de las muestras analizadas. En este análisis, una diferencia en la presencia o ausencia de un solo fragmento amplificado representaba una disimilitud del 1,3\%. Considerando los resultados por etapas del protocolo de crioconservación y un nivel de similitud del 100\%, la estabilidad genética va disminuyendo a medida que se avanza en el proceso hasta la etapa " $\mathrm{D}$ ". Todas las muestras correspondientes a los controles de ápices en condiciones in vitro ("A") y las muestras preaclimatadas con temperaturas alternantes ("N") son estables. En la etapa "P" la estabilidad genética media es del 95,2\%, siendo todas las muestras del control "MS" y del tratamiento con vitamina E ("VE") estables (Tabla 6.3). En la etapa "S" la estabilidad media es de un 90,5 $\%$ (en este caso sólo las muestras del tratamiento "AA" son el $100 \%$ estables); en "D" es del $70,0 \%$ (en el tratamiento "AA" la estabilidad es significativamente menor); y en "Cr" del $78,5 \%$.

Cuando se considera el $95 \%$ de similitud, se observa que las muestras recuperadas después de la osmoprotección (“S”) muestran una menor estabilidad (Tabla 6.3).

Los resultados medios por tratamiento antioxidante utilizado (Tabla 6.4), reflejan que la adición de sustancias antioxidantes no supone un aumento de la estabilidad; las muestras sometidas a ácido ascórbico resultan estables al 76 \%, y las sometidas a vitamina E en un 84,6 $\%$, valores menores a los obtenidos en el control (92\%).

Cinco muestras presentan los valores más bajos de similitud $(<95 \%)$ correspondiendo tan solo 2 de ellas a muestras crioconservadas (Fig. 6.3). 
Tabla 6.3. Porcentaje de estabilidad en cada paso y tratamiento del protocolo de crioconservación (marcadores RAPD), y porcentaje de estabilidad media por paso al 100 y 95 $\%$ de similitud. Detalles pasos y tratamientos en "Materiales y métodos".

\begin{tabular}{|c|c|c|c|c|c|c|c|c|}
\hline \multirow[b]{2}{*}{ Paso } & \multirow[b]{2}{*}{ Tratamiento } & \multirow[b]{2}{*}{$\begin{array}{c}\mathbf{N}^{\mathbf{o}} \\
\text { muestras } \\
\text { total }\end{array}$} & \multicolumn{3}{|c|}{ Estabilidad al $100 \%$ de similitud } & \multicolumn{3}{|c|}{ Estabilidad al $95 \%$ de similitud } \\
\hline & & & $\begin{array}{c}\mathbf{N}^{\circ} \text { muestras } \\
\text { estables }\end{array}$ & $\%$ & $\begin{array}{l}\text { Estabilidad } \\
\text { media por } \\
\text { pasos }(\%)\end{array}$ & $\begin{array}{c}\mathbf{N}^{\circ} \text { muestras } \\
\text { estables al } \\
95 \%\end{array}$ & $\%$ & $\begin{array}{l}\text { Estabilidad } \\
\text { media por } \\
\text { pasos }(\%)\end{array}$ \\
\hline A & - & 5 & 5 & 100 & 100 & 5 & 100 & 100 \\
\hline $\mathrm{N}$ & - & 5 & 5 & 100 & 100 & 5 & 100 & 100 \\
\hline \multirow{3}{*}{$\mathrm{P}$} & MS & 7 & 7 & 100 & \multirow{3}{*}{95,2} & 7 & 100 & \multirow{3}{*}{100} \\
\hline & AA & 7 & 6 & 85,7 & & 7 & 100 & \\
\hline & $\mathrm{VE}$ & 7 & 7 & 100 & & 7 & 100 & \\
\hline \multirow{3}{*}{ S } & MS & 7 & 6 & 85,7 & \multirow{3}{*}{90,5} & 6 & 85,7 & \multirow{3}{*}{95,2} \\
\hline & AA & 7 & 7 & 100 & & 7 & 100 & \\
\hline & VE & 7 & 6 & 85,7 & & 7 & 100 & \\
\hline \multirow{3}{*}{$\mathrm{D}$} & MS & 7 & 6 & $85,7 \mathrm{a}$ & \multirow{3}{*}{70,0} & 6 & 85,7 & \multirow{3}{*}{90,0} \\
\hline & $\mathrm{AA}$ & 6 & 2 & $33,3 b$ & & 5 & 83,3 & \\
\hline & VE & 7 & 6 & $85,7 \mathrm{a}$ & & 7 & 100 & \\
\hline \multirow{3}{*}{$\mathrm{Cr}$} & MS & 4 & 4 & 100 & \multirow{3}{*}{78,5} & 4 & 100 & \multirow{3}{*}{85,7} \\
\hline & AA & 5 & 4 & 80 & & 5 & 100 & \\
\hline & VE & 5 & 3 & 60 & & 3 & 60 & \\
\hline
\end{tabular}

Tabla 6.4. Porcentaje de estabilidad media por tratamiento antioxidante al 100 y $95 \%$ de similitud (marcadores RAPD). Tratamientos: "MS": control sin adición de antioxidantes; "AA" y "VE": adición de ácido ascórbico y vitamina E, respectivamente.

\begin{tabular}{|c|c|c|c|c|c|}
\hline \multirow[b]{2}{*}{$\begin{array}{l}\text { Tratamiento } \\
\text { antioxidante }\end{array}$} & \multirow[b]{2}{*}{$\begin{array}{c}\mathbf{N}^{0} \text { muestras } \\
\text { totales }\end{array}$} & \multicolumn{2}{|c|}{ Estabilidad al $100 \%$ de similitud } & \multicolumn{2}{|c|}{ Estabilidad al $95 \%$ de similitud } \\
\hline & & $\begin{array}{l}\mathbf{N}^{o} \text { Muestras } \\
\text { estables }\end{array}$ & $\begin{array}{c}\% \text { Estabilidad } \\
\text { media por } \\
\text { tratamiento }\end{array}$ & $\begin{array}{c}\mathbf{N}^{\circ} \text { Muestras } \\
\text { estables }\end{array}$ & $\begin{array}{c}\% \text { Estabilidad } \\
\text { media por } \\
\text { tratamiento }\end{array}$ \\
\hline MS & 25 & 23 & 92,0 & 23 & 92,0 \\
\hline AA & 25 & 19 & 76,0 & 24 & 96,0 \\
\hline VE & 26 & 22 & 84,6 & 24 & 92,3 \\
\hline
\end{tabular}




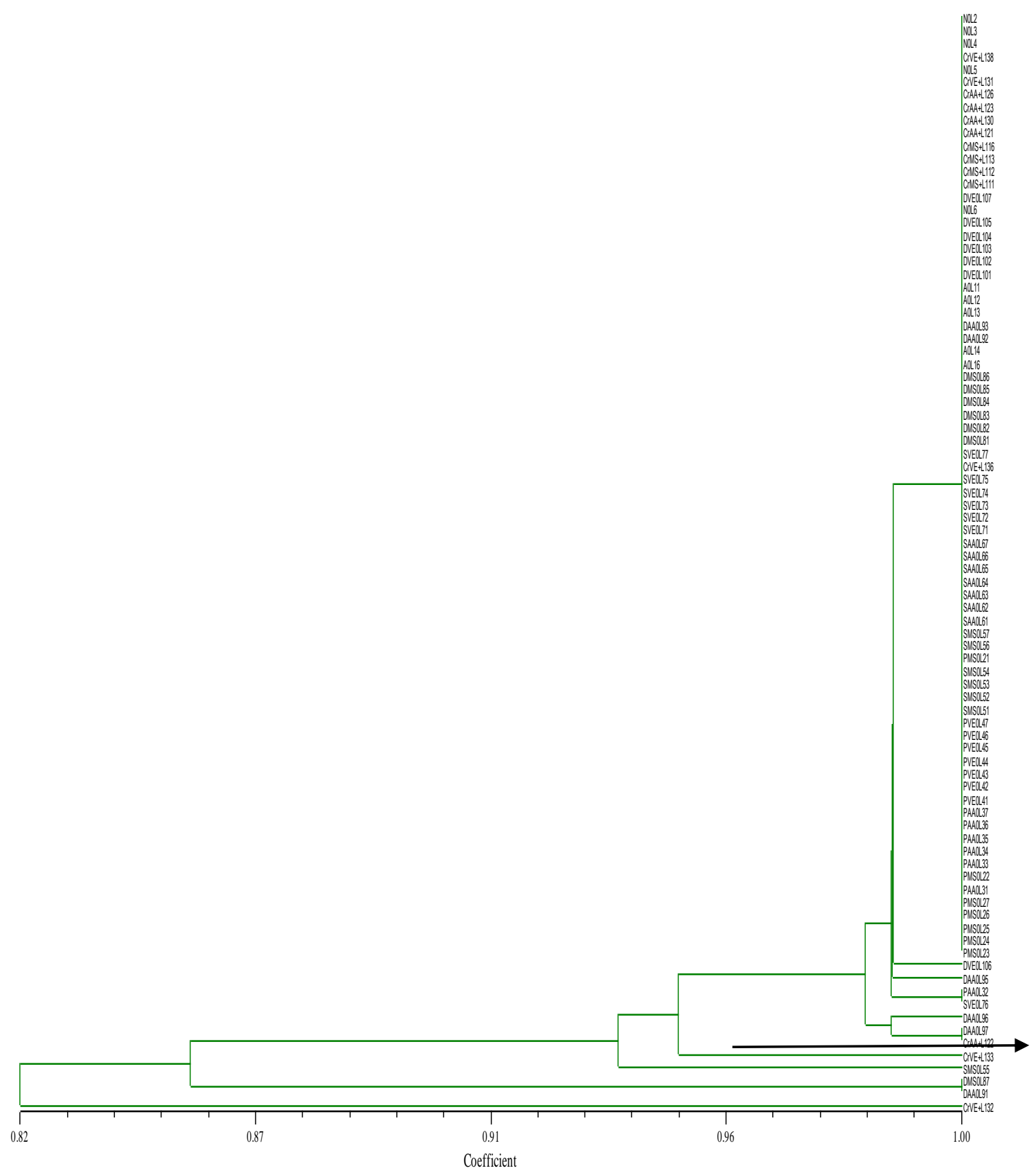

Figura 6.3. Dendrograma basado en marcadores RAPD de las muestras de material vegetal de 'MEN 198' tras 8 semanas de recuperación utilizando la técnica de encapsulacióndeshidratación. Pasos "A": control, hojas provenientes de cultivo in vitro; "N": precultivo y aclimatación de los segmentos; "P": precultivo de ápices; "S": cultivo de los ápices encapsulados; "D": deshidratación de las cuentas y "Cr": enfriamiento en nitrógeno líquido. Tratamientos de las muestras: sin antioxidante ("MS"), con ácido ascórbico ("AA") y vitamina E ("VE"); muestras sometidas a inmersión en nitrógeno líquido (+), y no crioconservadas (0). La última cifra indica el número de muestra. La flecha indica las muestras por debajo del $95 \%$ de similitud. 


\subsubsection{Marcadores AFLPs}

Las combinaciones de cebadores utilizadas produjeron 322 fragmentos para las 86 muestras estudiadas, presentando un polimorfismo del $95 \%$. La diferencia entre la presencia o ausencia de un fragmento representa una disimilitud del 0,5 al 0,9\%. En el dendrograma generado (Fig. 6.4) se observa un agrupamiento de 45 muestras con una similitud del $100 \%$, lo que representa el 52,3\% del total de las muestras analizadas. Este grupo de muestras es el que se considera genéticamente estable, y en él se encuentran el $100 \%$ de las muestras de las etapas "A" y "N"; el 76,2 \% de "P", el 57,1\% de "S", el 25,0 \% de "D" y el 14,3\% de "Cr" (Tabla 6.5). Al igual que se ha observado en los resultados obtenidos con RAPDs, estos datos reflejan una disminución en la estabilidad genética a medida que se avanza en el proceso de crioconservación. Cuando se considera el efecto de los tratamientos antioxidantes sobre la estabilidad (Tabla 6.6), los valores medios no parecen presentar una mejoría sobre el control ("MS"), tanto al $100 \%$ como al $95 \%$ de similitud.

Considerando un nivel de similitud del $95 \%$, tan solo 15 muestras quedan por debajo de este valor (17,4\%; Tabla 6.5). El $40 \%$ de ellas se corresponden a muestras crioconservadas (NL).

En cuanto al efecto de los antioxidantes, el valor medio de estabilidad disminuye con la utilización de ácido ascórbico y vitamina E. En la etapa "D" el porcentaje de estabilidad es significativamente menor que en el control ("DMS") al $100 \%$ de similitud. De forma similar, cuando se consideraba una similitud del $95 \%$, un menor porcentaje de las muestras recuperadas después de la crioconservación resultaban estables cuando habían sido tratadas con vitamina $\mathrm{E}$. 
Tabla 6.5. Porcentaje de estabilidad en cada paso y tratamiento del protocolo de crioconservación (marcadores AFLP), y porcentaje de estabilidad media por paso al 100 y 95 $\%$ de similitud. Detalles de los pasos y tratamientos en "Materiales y métodos". Dentro de una misma etapa, los porcentajes con la misma letra no son significativamente diferentes de acuerdo a la comparación por pares por $\operatorname{LSD}(\alpha=0,05)$.

\begin{tabular}{|c|c|c|c|c|c|c|c|c|}
\hline \multirow[b]{2}{*}{ Paso } & \multirow[b]{2}{*}{ Tratamiento } & \multirow[b]{2}{*}{$\begin{array}{c}\mathbf{N}^{\circ} \\
\text { muestras } \\
\text { total }\end{array}$} & \multicolumn{3}{|c|}{ Estabilidad al $100 \%$ de similitud } & \multicolumn{3}{|c|}{ Estabilidad al $95 \%$ de similitud } \\
\hline & & & $\begin{array}{c}\mathbf{N}^{\mathbf{o}} \\
\text { muestras } \\
\text { estables }\end{array}$ & $\%$ & $\begin{array}{c}\text { Estabilidad } \\
\text { media por } \\
\text { pasos }(\%)\end{array}$ & $\begin{array}{c}\mathbf{N}^{\circ} \\
\text { muestras } \\
\text { estables al } \\
95 \%\end{array}$ & $\%$ & $\begin{array}{l}\text { Estabilidad } \\
\text { media por } \\
\text { pasos (\%) }\end{array}$ \\
\hline A & & 5 & 5 & 100 & 100 & 5 & 100 & 100 \\
\hline $\mathrm{N}$ & & 5 & 5 & 100 & 100 & 5 & 100 & 100 \\
\hline \multirow{3}{*}{$\mathrm{P}$} & MS & 7 & 6 & 85,7 & \multirow{3}{*}{76,2} & 6 & 85,7 & \multirow{3}{*}{85,7} \\
\hline & AA & 7 & 5 & 71,4 & & 5 & 71,4 & \\
\hline & VE & 7 & 5 & 71,4 & & 7 & 100 & \\
\hline \multirow{3}{*}{$\mathrm{S}$} & MS & 7 & 2 & 28,6 & \multirow{3}{*}{57,1} & 5 & 71,4 & \multirow{3}{*}{85,7} \\
\hline & AA & 7 & 5 & 71,4 & & 7 & 100 & \\
\hline & VE & 7 & 5 & 71,4 & & 6 & 85,7 & \\
\hline \multirow{3}{*}{$\mathrm{D}$} & MS & 7 & 5 & $71,4 \mathrm{a}$ & \multirow{3}{*}{25,0} & 7 & 100 & \multirow{3}{*}{80,0} \\
\hline & AA & 6 & 0 & $0 \mathrm{~b}$ & & 4 & 66,7 & \\
\hline & VE & 7 & 0 & $0 \mathrm{~b}$ & & 5 & 71,4 & \\
\hline \multirow{3}{*}{$\mathrm{Cr}$} & MS & 4 & 1 & 25 & \multirow{3}{*}{14,3} & 4 & $100 \mathrm{a}$ & \multirow{3}{*}{57,1} \\
\hline & AA & 5 & 1 & 20 & & 3 & $60 \mathrm{a}$ & \\
\hline & VE & 5 & 0 & 0 & & 1 & $20 \mathrm{~b}$ & \\
\hline
\end{tabular}

Tabla 6.6. Porcentaje de estabilidad media por tratamiento antioxidante al 100 y $95 \%$ de similitud (marcadores AFLP). Tratamientos: "MS": control sin adición de antioxidantes; "AA" y "VE": adición de ácido Ascórbico y vitamina E, respectivamente.

\begin{tabular}{|c|c|c|c|c|c|}
\cline { 2 - 6 } \multicolumn{2}{c|}{} & \multicolumn{2}{c|}{ Estabilidad al 100\% de similitud } & \multicolumn{2}{c|}{ Estabilidad al 95\% de similitud } \\
\hline $\begin{array}{c}\text { Tratamiento } \\
\text { antioxidante }\end{array}$ & $\begin{array}{c}\mathbf{N}^{\mathbf{0}} \text { muestras } \\
\text { totales }\end{array}$ & $\begin{array}{c}\mathbf{N}^{\mathbf{0}} \text { Muestras } \\
\text { estables al } \\
\mathbf{1 0 0 \%}\end{array}$ & $\begin{array}{c}\text { Estabilidad } \\
\text { media } \\
(\%)\end{array}$ & $\begin{array}{c}\mathbf{N}^{\mathbf{}} \text { Muestras } \\
\text { estables al 95\% }\end{array}$ & $\begin{array}{c}\text { Estabilidad } \\
\text { media } \\
(\%)\end{array}$ \\
\hline MS & 25 & 14 & 56,0 & 22 & 88,0 \\
\hline AA & 25 & 11 & 44,0 & 19 & 76,0 \\
\hline VE & 26 & 10 & 38,5 & 20 & 76,9 \\
\hline
\end{tabular}




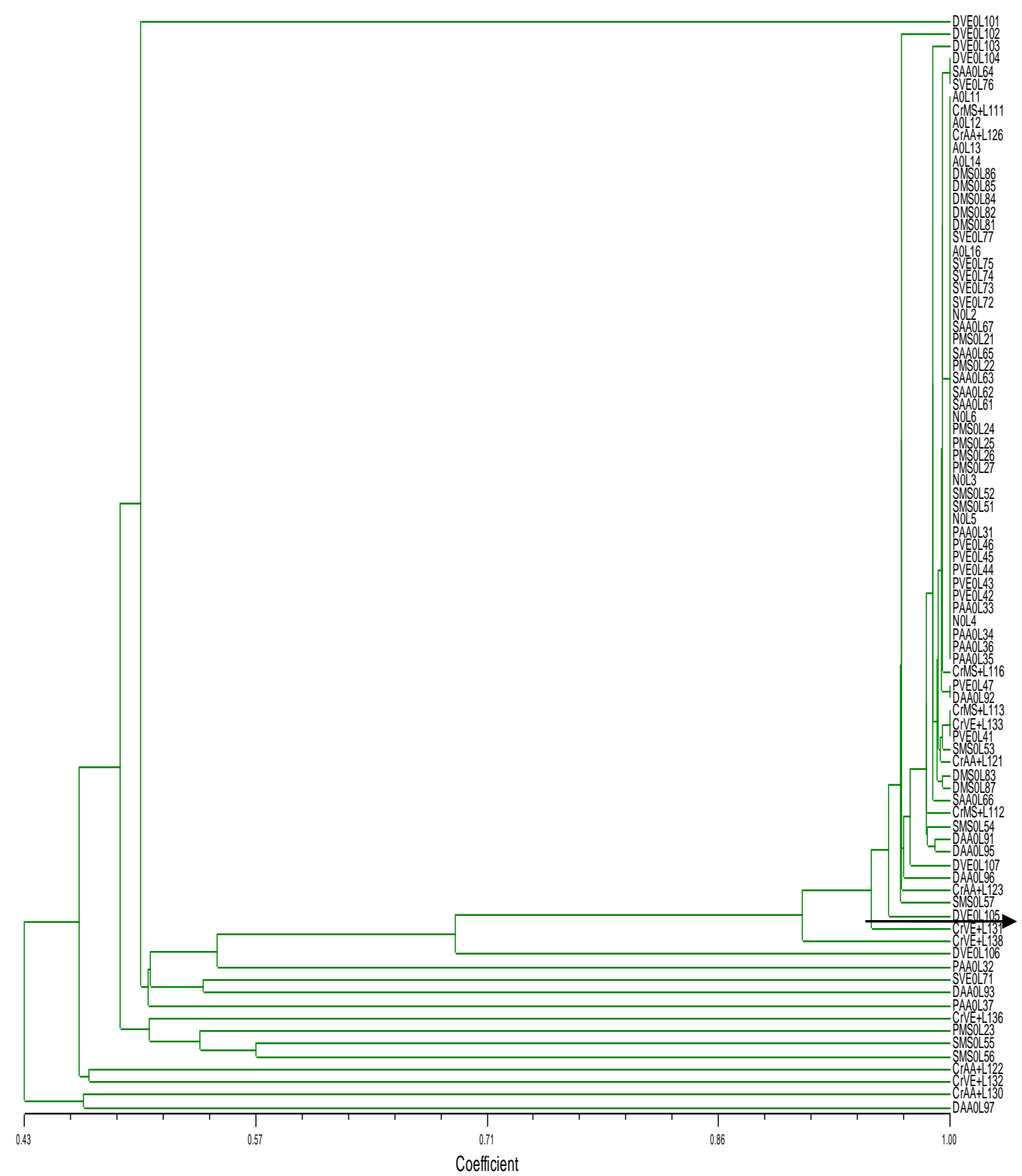

Figura 6.4. Dendrograma basado en marcadores AFLP de las muestras de material vegetal de 'MEN 198' tras 8 semanas de recuperación utilizando la técnica de encapsulacióndeshidratación. Pasos "A": control, hojas provenientes de cultivo in vitro; "N": precultivo y aclimatación de los segmentos; "P": precultivo de ápices; "S": cultivo de los ápices encapsulados; " $D$ ": deshidratación de las cuentas y "Cr": enfriamiento en nitrógeno líquido.Tratamientos de las muestras: sin antioxidante ("MS"), con ácido ascórbico ("AA") y vitamina E ("VE"); muestras sometidas a inmersión en nitrógeno líquido (+), y no crioconservadas (0). La última cifra indica el número de muestra. La flecha indica las muestras por debajo del $95 \%$ de similitud. 


\subsubsection{Producción de ROS y NO}

En un primer ensayo se determinó la acumulación de ROS y NO inmediatamente después de diversos pasos del protocolo de crioconservación ("N", "P”, "S" y "Cr", ver Fig. 3.5) mediante sondas fluorescentes. Utilizando la sonda específica DCF-DA para $\mathrm{H}_{2} \mathrm{O}_{2}$ no se observaron diferencias de señal entre las muestras con y sin secuestrador en ninguna de las etapas estudiadas (Fig. 6.5, Tabla 6.7, ver anejo Fig. 9.1, Fig. 9.2). En la medición de NO mediante la sonda DAF-2 DA tampoco hubo diferencias entre las muestras con y sin secuestrador (Fig. 6.5, Tabla 6.7, ver anejo Fig. 9.3, Fig. 9.4). Sin embargo, en la detección del radical superóxido $\mathrm{O}_{2}{ }^{\bullet-}$ con la sonda DHE, sí se detectó una mayor fluorescencia en las etapas "N", "P" y "S", siendo esta última en la que se observaba una mayor concentración de $\mathrm{O}_{2}{ }^{-}$(Figs. 6.5, 6.6, Tabla 6.7, ver anejo Fig. 9.5, Fig. 9.6). Con esta sonda no se observó señal fluorescente en la etapa "Cr". Estos resultados indican que a medida que se avanza en los diferentes pasos de la crioconservación existe una acumulación de $\mathrm{O}_{2}{ }^{{ }^{*}}$ en las células, lo que podría estar provocando un mayor daño oxidativo. Sin embargo, tras un día de recuperación de los explantos en el medio de cultivo (etapa "Cr") la acumulación de $\mathrm{O}_{2}{ }^{*-}$ se habría reducido.

En un segundo estudio se incluyeron las etapas "P" y "S" del protocolo de crioconservación en las que se había incluido 0,43 mM ácido ascórbico (denominadas "Pa" y "Sa" respectivamente). En este caso, solo se utilizó la sonda DHE, que había dado resultados positivos en el primer estudio. De nuevo se confirmó mayor acumulación de $\mathrm{O}_{2}{ }^{*}$ en la etapa "S" del protocolo y algo más baja en la etapa "P". Las imágenes tomadas de ambas etapas del protocolo en las que se había incluido el antioxidante ("Pa" y "Sa") mostraban una reducción de la fluorescencia (Fig. 6.7, ver anejo Fig. 9.6, Fig. 9.7), llegando a un nivel de señal similar al de la etapa "N". 

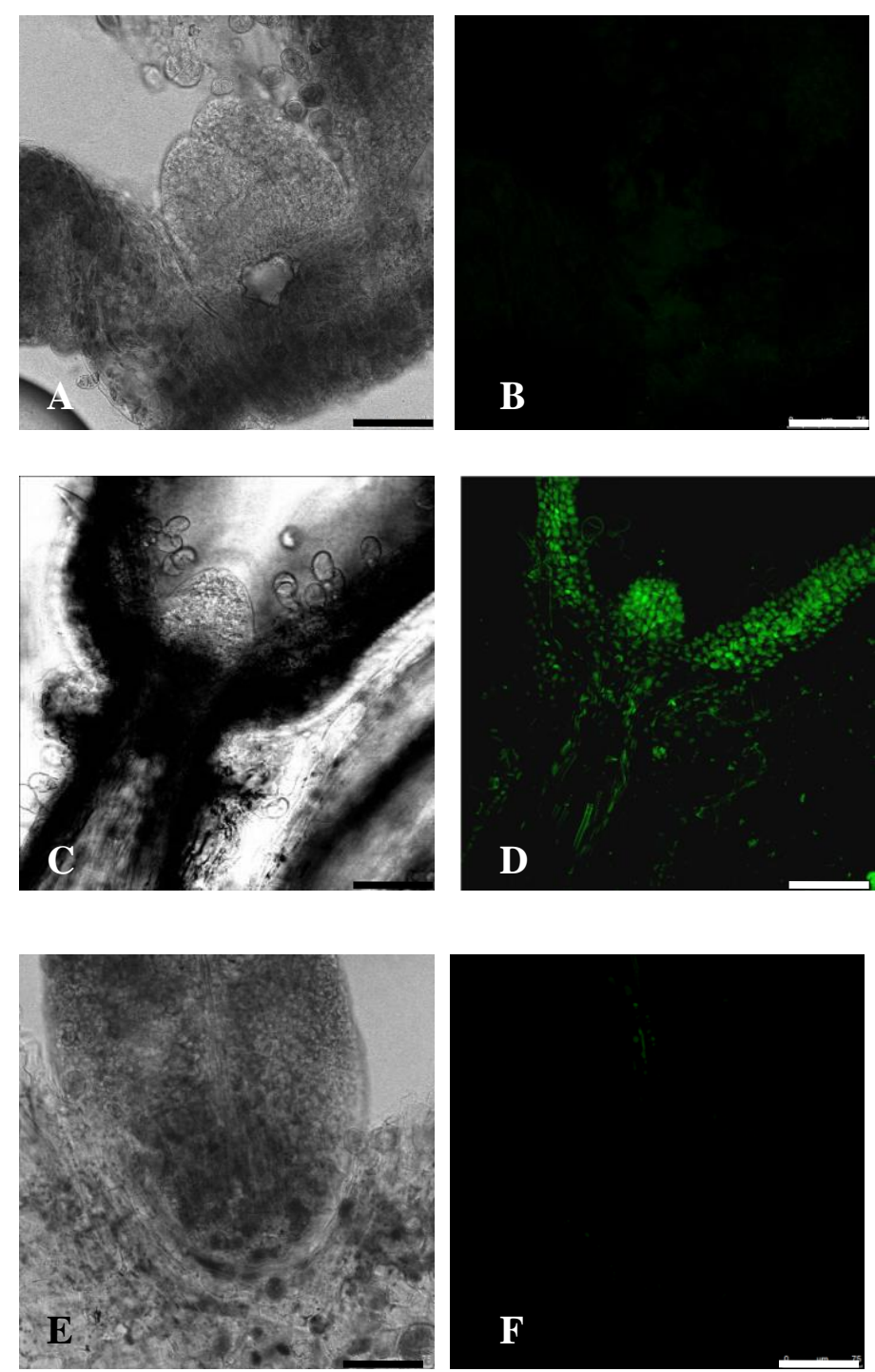

Figura 6.5. Imágenes con luz visible (A, C y E) y proyecciones de varias secciones ópticas recogidas por microscopía confocal que muestra la fluorescencia debido a DAF-2DA (B), DHE (D) y DCF-DA (F) en la etapa "S" de la crioconservación. Se representa solo la etapa "S" con las tres sondas fluorescentes ya que fue en la que se detectó mayor señal con DHE (ver anejo X para el resto de las imágenes). Barra $=75 \mu \mathrm{m}$. 
Tabla 6.7. Presencia de señal en análisis mediante fluorocromos en las etapas "N", "A", "P", "S" y "Cr" de la crioconservación por encapsulación-deshidratación en ápices de 'MEN 198'. Ausencia de señal $(-)$, señal baja $(+)$, señal media $(++)$, señal alta $(+++)$.

\begin{tabular}{|c|c|c|}
\hline Paso & ROS/Fluorocromo & Señal \\
\hline \multirow{3}{*}{$\mathrm{N}$} & $\mathrm{H}_{2} \mathrm{O}_{2} /$ DCF-DA & - \\
\hline & $\mathrm{NO} / \mathrm{DAF}-2 \mathrm{DA}$ & - \\
\hline & $\mathrm{O}_{2}{ }^{\bullet-} / \mathrm{DHE}$ & + \\
\hline \multirow{3}{*}{$\mathrm{P}$} & $\mathrm{H}_{2} \mathrm{O}_{2} /$ DCF-DA & - \\
\hline & NO /DAF-2DA & - \\
\hline & $\mathrm{O}_{2}^{\cdot-} / \mathrm{DHE}$ & ++ \\
\hline \multirow{3}{*}{$S$} & $\mathrm{H}_{2} \mathrm{O}_{2} / \mathrm{DCF}-\mathrm{DA}$ & - \\
\hline & NO /DAF-2DA & - \\
\hline & $\mathrm{O}_{2} \cdot-/ \mathrm{DHE}$ & +++ \\
\hline \multirow{3}{*}{$\mathrm{Cr}$} & $\mathrm{H}_{2} \mathrm{O}_{2} / \mathrm{DCF}-\mathrm{DA}$ & - \\
\hline & NO /DAF-2DA & - \\
\hline & $\mathrm{O}_{2}{ }^{\bullet-} / \mathrm{DHE}$ & - \\
\hline
\end{tabular}



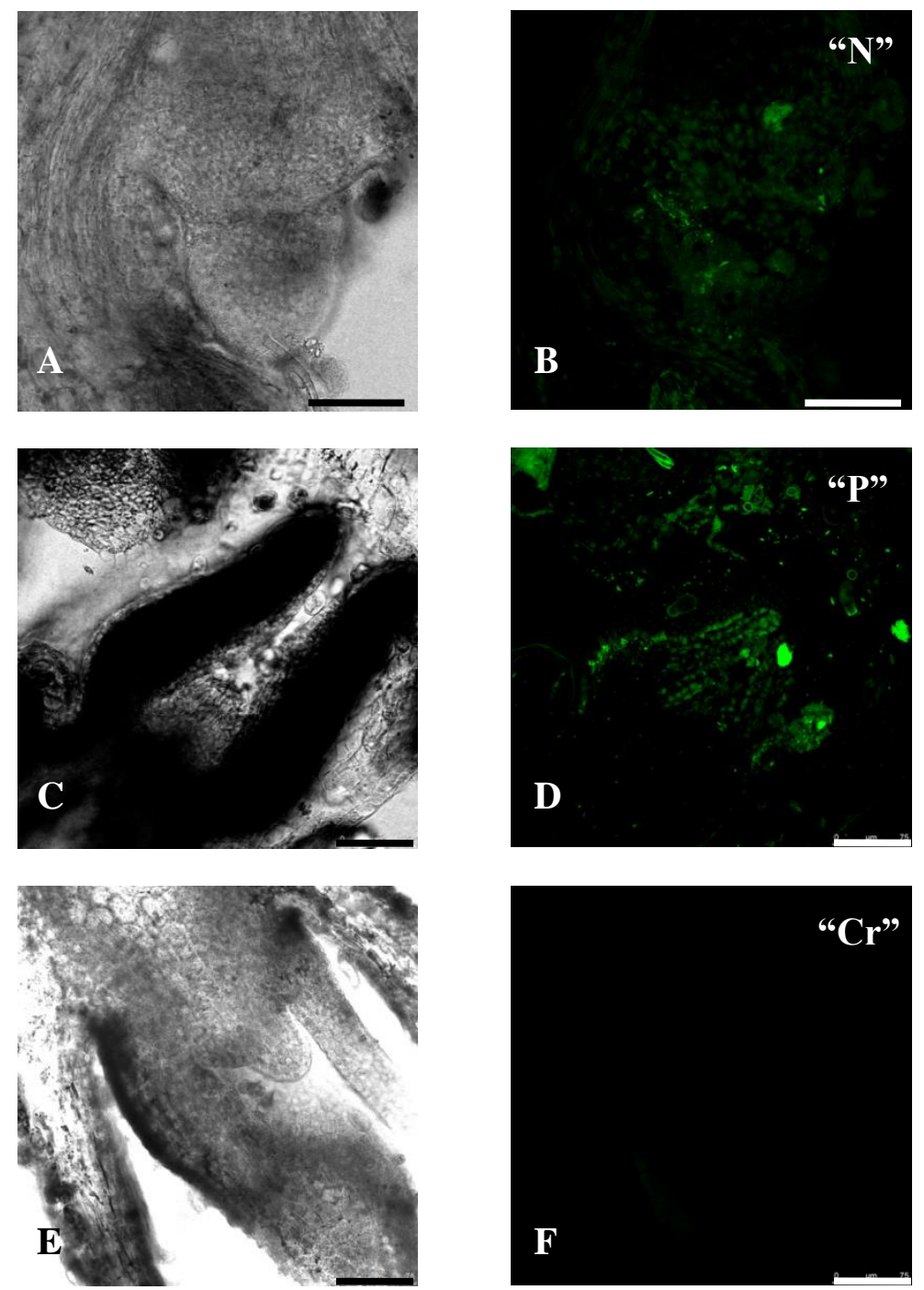

Figura 6.6. Imágenes con luz visible (A, C y E) y proyecciones de varias secciones ópticas recogidas por microscopía confocal que muestra la fluorescencia debido a DHE $(\mathrm{B}, \mathrm{D}, \mathrm{F})$ después de las etapas de crioconservación "N" (A, B), "P" (C, D) y “Cr" (E, F). Barra= 75 $\mu \mathrm{m}$. 

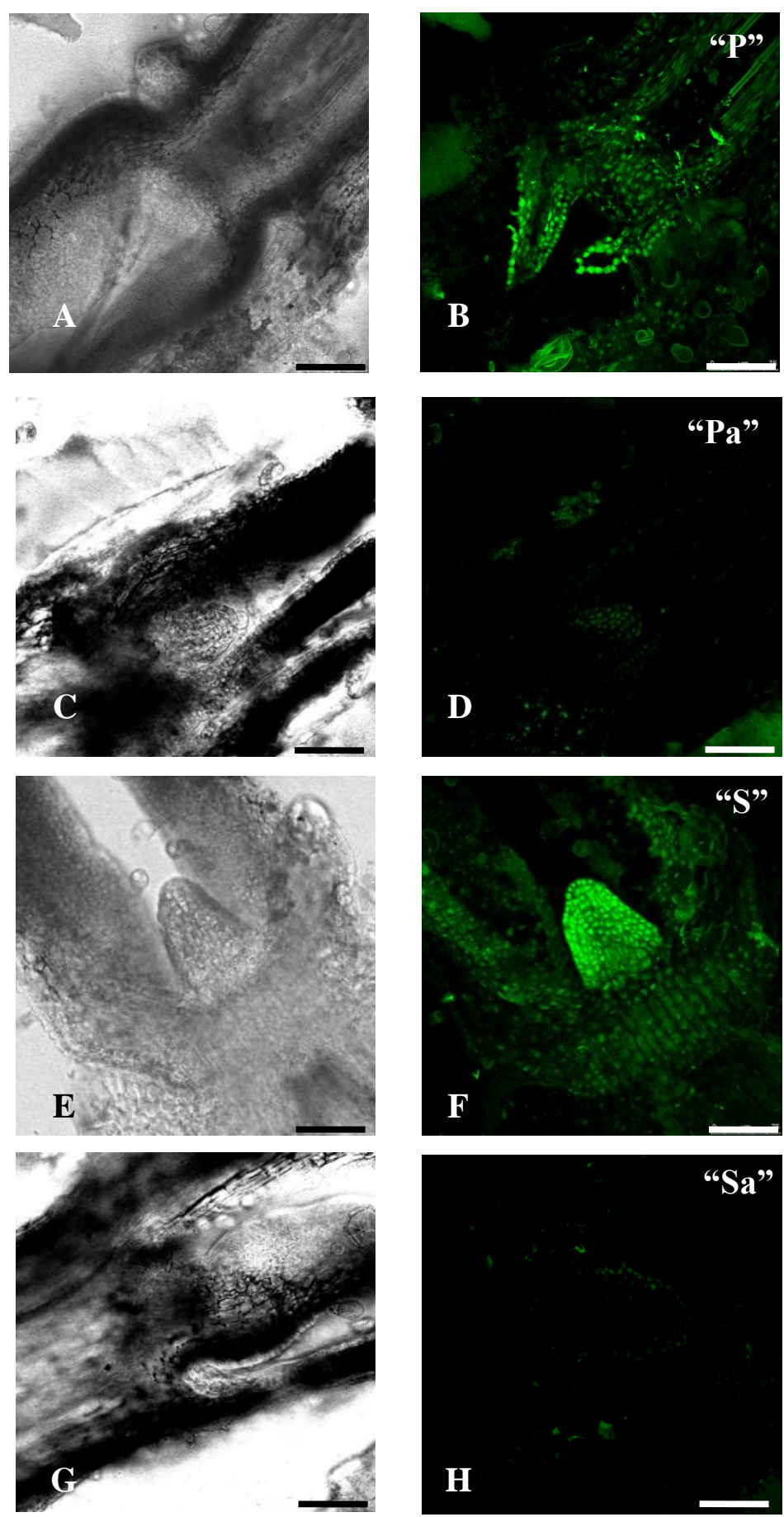

Figura 6.7. Imágenes con luz visible (A, C, E, G) y proyecciones de varias secciones ópticas recogidas por microscopía confocal que muestra la fluorescencia debido a DHE (B, D, F, H) después de las etapas de crioconservación "P" (A-D) o "S" (E-H), sin incluir antioxidante (A, B, E y F) o incluyendo antioxidante (C, D, G, H). Barra $=75 \mu \mathrm{m}$. 


\subsubsection{Cuantificación de MDA}

La cantidad de MDA (producto de la oxidación de ácidos grasos poliinsaturados) presente en los tejidos en las primeras etapas del proceso de crioconservación (desde el material in vitro "A" al cultivo en 0,3 M sacarosa "P") fue de 5,5-9,8 nmoles/ g pf, no encontrándose diferencias entre esos valores (Fig. 6.8). Sin embargo, después del tratamiento del ápice encapsulado en 0,75 M sacarosa ("S"), la cantidad de MDA producida aumentaba drásticamente hasta alcanzar 29,9 nmoles/g pf. Los ápices crioconservados y cultivados durante un día mostraban valores bajos de MDA (2,2 nmoles/g pf). La adición de 0,43 mM ácido ascórbico en la etapa de precultivo "P”, no tuvo como efecto una disminución en la formación de MDA (Fig. 6.8). Sin embargo, en el caso de la etapa "S", la adición del antioxidante provocó una disminución del MDA de 29,9 a 4,6 nmoles/g pf. Los ápices crioconservados (después de un día de recuperación) que habían sido tratados con antioxidante en la etapa "P” (“Crp") o "S" (“Crs") mantuvieron niveles bajos de MDA.

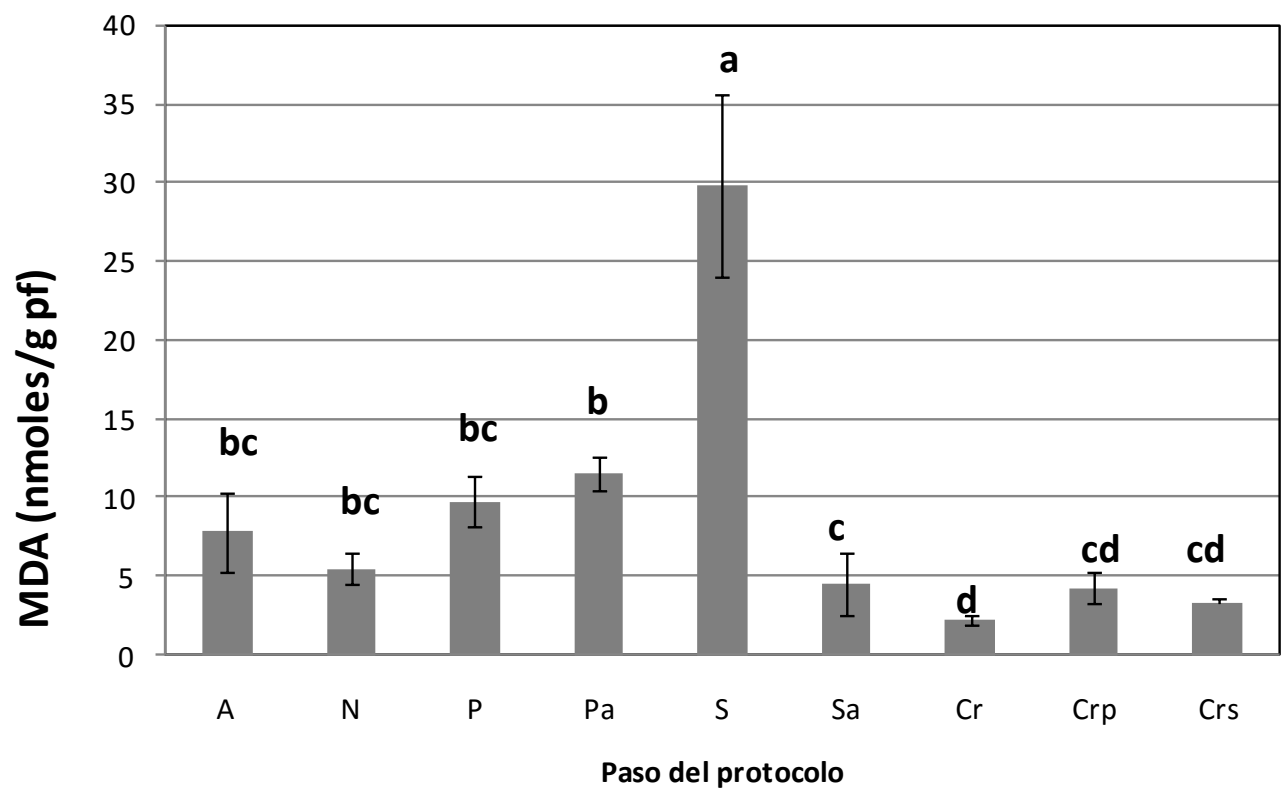

Figura 6.8. Valores de MDA obtenidos en cada paso del proceso de encapsulacióndeshidratación. Tratamiento "Pa" y "Sa" con ácido ascórbico. "Crp" y "Crs" muestras crioconservadas provenientes de tratamiento con antioxidante en etapa "P" y "S", respectivamente. Barras: error estándar. Medias con la misma letra no son significativamente diferentes de acuerdo con el test de comparaciones múltiples de Duncan $(\alpha=0,05)$. 


\subsubsection{Determinación de la Capacidad Antioxidante Mediante el Método ABTS}

Se estudió el contenido de antioxidantes de ambos genotipos de menta (Fig. 6.9). Se observó una mayor capacidad antioxidante en las muestras del genotipo 'MEN 186' frente a las de 'MEN 198' ( $\mathrm{p}<0,000$ ). En ambos genotipos aquellas muestras provenientes de cultivo in vitro ("v") mostraron más capacidad antioxidante que las muestras ex vitro en ambos genotipos ( $\mathrm{p}=0,02)$. La utilización de PVP ("P”) durante la extracción no mostró diferencias significativas con las muestras equivalentes extraídas sin PVP.

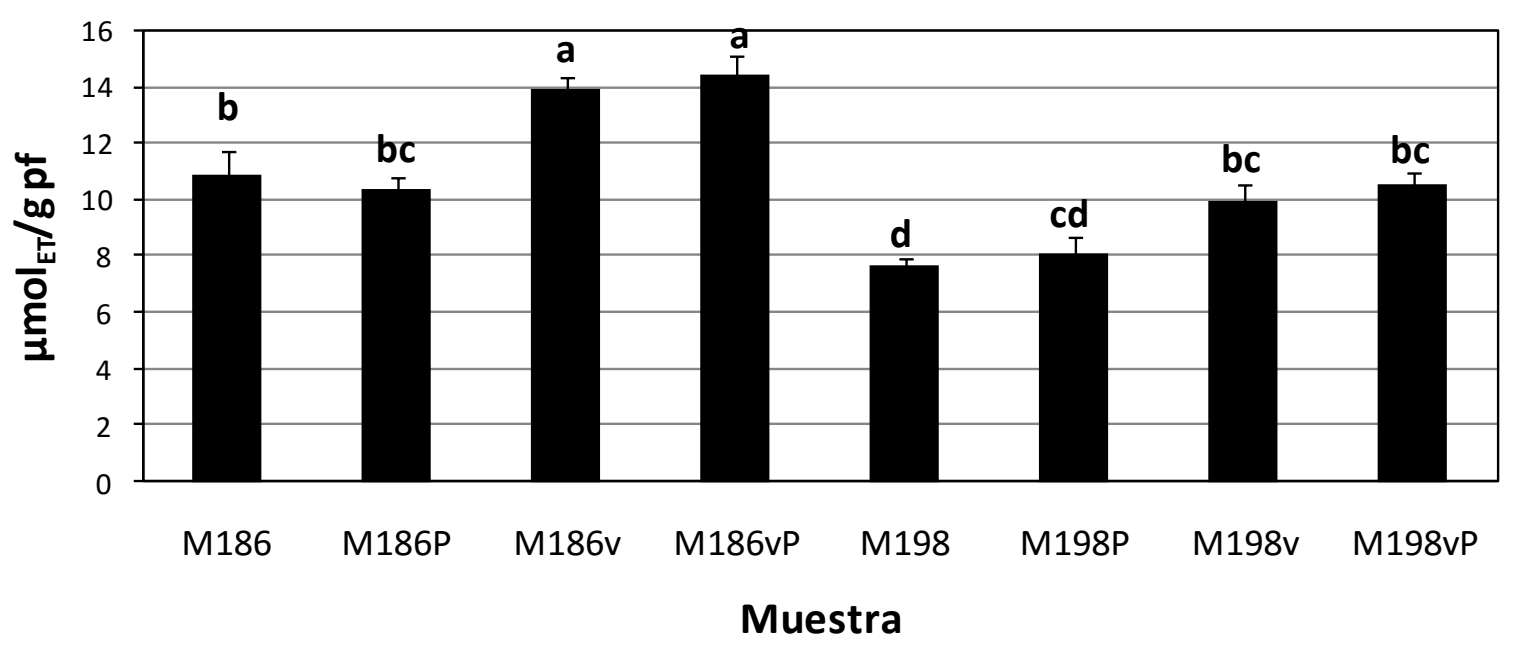

Figura 6.9. Actividad antioxidante equivalente en Trolox de los genotipos de menta 'MEN 186' y 'MEN 198' cultivados en maceta o in vitro (“v"); en las muestras con "P” se utilizó PVP para la extracción. Barra: error estándar. Medias con la misma letra no son significativamente diferentes de acuerdo con el test de comparaciones múltiples de Duncan ( $\alpha$ $=0,05)$. 


\subsection{Discusión}

En el presente estudio, se realizó un análisis secuencial tras cada etapa del proceso de crioconservación por encapsulación-deshidratación en el genotipo de menta 'MEN 198', una vez transcurridas 8 semanas de recuperación de los ápices. El primer objetivo fue determinar la o las etapas donde se produce un mayor daño por estrés oxidativo, mediante el análisis de la estabilidad genética, y en la supervivencia y recuperación de los explantos. Asimismo, se analizó el efecto de la adición de antioxidantes (ácido ascórbico y vitamina E) en la etapa de precultivo de los ápices para estas mismas variables.

Los primeros resultados obtenidos muestran que la supervivencia (en menor medida) y recuperación de los ápices disminuye a medida que se avanza en el proceso de crioconservación. Si nos basamos en los resultados a las 8 semanas, la supervivencia alcanzada es del $100 \%$ tanto en el control "A" como en las etapas "N", "P" y "S", y a partir de la etapa " $\mathrm{D}$ " disminuye, aunque sólo es significativamente diferente en la etapa "Cr". La recuperación se ve afectada significativamente en las etapas " $D$ " y en "Cr". Esto nos indica que la deshidratación física es un procedimiento que podría estar causando lesiones en los tejidos o generando estrés oxidativo, y que incluso estarían provocando la muerte celular. Durante la inmersión en NL o el calentamiento de los ápices también se producirían daños o crio-lesiones. Una posible causa sería que con los tratamientos previos a la crioconservación no se logra eliminar toda el agua congelable de los ápices y que hubiese formación de cristales de hielo, provocando daños en las células, y que los ápices, a pesar de sobrevivir, pierdan la capacidad de recuperarse. Sin embargo, estudios previos del mismo protocolo de crioconservación aplicados a ápices de menta demostraron que después de $5 \mathrm{~h}$ de desecación tanto la cuenta de alginato como el ápice vitrificaban (Teixeira at al. 2014). Otra causa sería que en esta última etapa habría un efecto acumulativo de los daños provocados a lo largo de todo el proceso. Dumet y Benson (2000) mencionan que las crio-lesiones o daños durante la crioconservación pueden ser debidas a lesiones físicas y eventos bioquímicos asociados a los tratamientos aplicados, y que promueven cambios sub-letales como desacoplamiento metabólico que pueden conducir a la producción de radicales libres tóxicos. Los resultados de recuperación tras la crioconservación obtenidos en este estudio (52 \%) fueron similares a los publicados por otros autores que evaluaron la recuperación tras la encapsulacióndeshidratación de menta, donde Hirai y Sakai (1999), Sakai y col. (2000) y Uchendu y col. (2008) obtuvieron valores de $50 \%, 51,7 \%$ y $40 \%$ de recuperación respectivamente. 
González-Arnao y Engelmann (2006) sugieren algunos procedimientos para optimizar el proceso de encapsulación-deshidratación y aumentar así la recuperación de los explantos. El uso de diferentes concentraciones de sacarosa en el precultivo de los ápices (entre 0,25 - 1,25 M) y por tiempos de incubación más largos (1 a 7 días), o un aumento gradual en la concentración de sacarosa en la osmoprotección reducirían el efecto negativo del estrés osmótico e incrementaría la recuperación de los explantos. Se ha utilizado con éxito en ápices de uva (Plessis et al. 1991) y manzana (Zhao et al. 1999) y en Citrus (González-Arnao et al. 1998). Cho y col. (2002) utilizaron una solución de sacarosa 0,3 M más 0,5 M de glicerol para la osmoprotección de Citrus madurensis y Matsumoto (2001) utilizó 0,8 M de sacarosa más 1 M de glicerol en wasabi. Esta combinación reduce los niveles de lesiones provocadas durante la posterior desecación (González-Arnao y Engelmann 2006, Matsumoto, 2001).

La adición de sustancias antioxidantes en la etapa "P" no supuso una mejora significativa en la supervivencia y recuperación de los ápices crioconservados. Sin embargo, sí se observó un aumento significativo de la regeneración de los ápices correspondientes a la etapa " $\mathrm{D}$ " con la adición de vitamina E. Estos resultados se contraponen a los obtenidos por Uchendu y col. (2010a) donde utilizaron vitamina E y ácido ascórbico en diferentes etapas en la vitrificación de ápices de Rubus (en la solución de carga, en solución de lavado y medio de recuperación) y encontraron un efecto significativo en la recuperación de los explantos crioconservados con ambos tratamientos antioxidantes. Johnston y col. (2007) también obtuvieron una mejora en la supervivencia y regeneración tras la encapsulación-deshidratación de ápices de Ribes spp., utilizando ácido ascórbico en diferentes etapas del procedimiento. Benson y col. (2013) sugieren que el uso de antioxidantes en el medio de recuperación de los explantos ayudaría a la recuperación de los supervivientes y a la reanudación de su funcionamiento normal. En el caso de la encapsulación-deshidratación de Mentha $\times$ piperita L. los tratamientos antioxidantes podrían utilizarse en otras etapas, como en la osmoprotección y analizar su efecto en la recuperación.

Johnston y col. (2007) también analizaron las diferencias entre dos genotipos de Ribes, uno tolerante a la crioconservación y otro más sensible. Visualmente observaron una acumulación de pigmentos rojos en la variedad tolerante al frío durante la preaclimatación al frío (simulada con una exposición a altas concentraciones de sacarosa). Estos pigmentos rojos se deben a la presencia de antocianas, que tienen un rol potencialmente protector ante el estrés por frío, cctúan como antioxidantes, osmolitos compatibles durante la deshidratación/enfriamiento y protectoras contra la fotooxidación (Johnston et al. 2007). El genotipo ('MEN 198'), que 
muestra porcentajes de recuperación superiores a 'MEN 186' después de la crioconservación (ver capítulo 4), también presentó esta coloración rojiza en los segmentos nodales y ápices tras la preaclimatación al frío (ver capítulo 3, Fig 3.1); la diferente respuesta entre cultivares reflejaría su distinto origen: Cuba para 'MEN 186' y Alemania para 'MEN 198'.

Mediante el uso de marcadores moleculares (RAPD y AFLP) se evaluó el estado de la estabilidad genética del material recuperado a las 8 semanas de cultivo de los ápices, tratados en cada etapa del proceso, y el efecto de la adición de antioxidantes en el precultivo de ápices. Los resultados con marcadores AFLP mostraron un nivel de polimorfismo mucho mayor que con RAPD (95\% vs 34,8\%), lo que demuestra la mayor sensibilidad de esta técnica para detectar inestabilidad genética. Ambos tipos de marcadores reflejaron una clara pérdida de estabilidad genética a lo largo del proceso que iría en paralelo a la pérdida de capacidad de recuperación de los ápices también observada.

Durante el cultivo in vitro ("A") y la preaclimatación al frío ("N") no hubo cambios en la estabilidad genética, y la variabilidad comenzaba a aparecer a partir de la etapa "P" del procedimiento, e iba aumentando a medida que se avanzaba en el protocolo de crioconservación, como un efecto acumulativo de inestabilidad. En los datos de recuperación se observó un efecto positivo de la vitamina E en los ápices correspondientes al paso " $D$ ”. Sin embargo, ninguno de los marcadores moleculares ha detectado un aumento de la estabilidad genética en dichas muestras, lo que cuestionaría la relación entre 'capacidad de recuperación' y 'estabilidad genética'. Otra de las relaciones normalmente asumidas es que una mayor producción de callo está asociada a una mayor aparición de variación somaclonal. En los resultados obtenidos en este trabajo, se observó una reducción total de la formación de callo (como única respuesta, aunque sí se apreció formación de callo en la base de algunos brotes) en las muestras crioconservadas sometidas a ácido ascórbico. La reducción en la formación de callo en este grupo de muestras no se ha traducido, sin embargo, en una mayor estabilidad genética de las muestras. El estudio de la estabilidad genética del callo y de los brotes formados a partir de él en crisantemo (Miñano et al., 2009) reveló que a partir de callos inestables es posible regenerar yemas estables, lo cual explicaría, como en este estudio, la falta de correlación entre estabilidad y formación de callo.

La variación genética observada en los pasos "P" y "S" podría estar asociada al estrés osmótico que ejerce la sacarosa, lo que se ha observado en el estudio de encapsulacióndeshidratación en crisantemo (Martín et al. 2011). En la etapa “D” se añaden, además, los 
posibles daños causados por la deshidratación física. En este sentido, Fernandes y col. (2008) analizaron la estabilidad genética (mediante citometría de flujo y marcadores AFLP y SSR) en la deshidratación hasta el 25 y $35 \%$ de peso fresco en embriones somáticos de roble y encontraron polimorfismos al $25 \%$ de deshidratación, y no al $35 \%$. El efecto negativo del exceso de deshidratación en los tejidos puede estar también asociado a un aumento de estrés osmótico, de la misma manera que se ha observado con las altas concentraciones de sacarosa.

Estos resultados nos confirman la hipótesis planteada por Martín y col. (2011, 2015), según la cual la variación genética producida a causa de la crioconservación aparece durante los tratamientos previos a la inmersión en NL, y por tanto el enfriamiento no sería ni la única ni la principal causa de inestabilidad. Otro estudio sobre la estabilidad genética en material crioconservado apuntan al mismo efecto negativo de los pretratamientos sobre la aparición de variabilidad (Fernandes et al. 2008) Por otra parte, en diversos artículos publicados no se ha encontrado variabilidad genética en el proceso de crioconservación (Sangeeta et al. 2002; Dixit et al. 2003; Zhai et al. 2003; Kaczmarczyk et al. 2011; Harding y Benson 2000; Mandal et al. 2008; Hao et al. 2001; Turner et al. 2001), o sí se encontró variación sólo en aquellos explantos sometidos a inmersión en NL (Hao et al. 2002).

Al igual que se observó en los datos correspondientes a la recuperación de los ápices, la adición de antioxidantes en la etapa "P" no ha supuesto una mayor estabilidad genética. Estos resultados parecen indicar que los tratamientos realizados en menta no han sido los adecuados bien por las concentraciones empleadas o por el momento del protocolo en el que se ha aplicado el antioxidante.

Para correlacionar la inestabilidad genética observada y disminución en la recuperación de los ápices con procesos de oxidación, se analizó el nivel de estrés oxidativo que ejerce cada etapa del procedimiento de encapsulación-deshidratación sobre el material vegetal y el efecto de la adición de ácido ascórbico en las etapas "P" o "S" en la disminución del mismo. Se evaluó el estado de oxidación tras diferentes etapas del protocolo mediante la medición del radical superóxido $\left(\mathrm{O}_{2}{ }^{-}\right)$(de los radicales estudiados, el único que mostró diferencias), y con la determinación del grado de peroxidación lipídica, estimada por las cantidades de MDA presente en los tejidos.

Se detectó la presencia del radical $\mathrm{O}_{2}{ }^{*-}$ a partir de la etapa "N" y un aumento significativo de la producción de malondialdehído en la etapa "S" (cultivo en 0,75 M sacarosa). 
En el proceso de preaclimatación al frío ("N") comenzaría a producirse estrés oxidativo, reflejado por la formación $\mathrm{O}_{2}{ }^{\bullet-}$. En la etapa "P" el estrés osmótico provocado por una mayor concentración de sacarosa provocó un aumento en la formación del radical $\mathrm{O}_{2}{ }^{\circ-}$, aunque no en la formación de MDA. Uchendu y col. (2010a) utilizando sustancias antioxidantes en la crioconservación (por vitrificación) de Rubus y observaron una reducción significativa de MDA en todas las etapas estudiadas. Sin embargo, la utilización de ácido ascórbico en dicho paso del protocolo no redujo la cantidad de MDA producida en el presente estudio que, aún sin antioxidante, era similar al de las muestras control in vitro (“A”). Por el contrario, la utilización de ácido ascórbico sí redujo los niveles detectados de $\mathrm{O}_{2}{ }^{\circ}$.

Los valores máximos alcanzados, tanto en la detección del radical $\mathrm{O}_{2}{ }^{*-}$ como en la formación de MDA, fueron detectados en la etapa "S" del protocolo, como consecuencia del estrés durante la osmoprotección. Con el tratamiento antioxidante, ambos componentes se vieron drásticamente reducidos, indicando que es el momento adecuado para el uso de antioxidantes. Esto indicaría que, durante la etapa de cultivo en 0,75 M sacarosa de los ápices encapsulados se infringe a los ápices el mayor estrés a lo largo del proceso de crioconservación, dentro de los pasos estudiados, lo que provoca un mayor daño oxidativo. Los estudios realizados hasta el momento aplicando sustancias antioxidantes durante la crioconservación se han llevado a cabo en plantas en la técnica de vitrificación (Ren et al. 2013; Wang y Deng 2004; Uchendu et al. 2010a; 2010b; 2013), o incluso con células animales utilizando protocolos de enfriamiento lento (p.e. semen Vasconcelos et al. 2014). En estos protocolos las concentraciones de sacarosa fueron inferiores. En los ápices crioconservados (“Cr") y tras un día de recuperación en oscuridad, no hubo señal que indicara la presencia de $\mathrm{O}_{2}{ }^{--}$y la medición de MDA fue la menor detectada entre todos los pasos estudiados. De esta manera, con los resultados obtenidos, se vuelve a confirmar la hipótesis de que los pasos previos o pretratamientos antes de la inmersión en NL provocan estrés oxidativo en los tejidos y por consiguiente se producirían daños en las células y, posiblemente, al ADN.

Con el objetivo de determinar la capacidad antioxidante presente en los dos genotipos de menta estudiados en esta tesis ('MEN 186' y 'MEN 198') se evaluó su capacidad de anular la reactividad de los radicales libres y/o de inhibir su generación (Avello y Suwalsky 2006) mediante la técnica ABTS. Se comparó material vegetal de plantas proveniente de cultivo in vitro que habían sido aclimatadas y mantenidas en invernadero y de vástagos cultivados in vitro; también se evaluó el efecto del uso de PVPP en el proceso de extracción de los antioxidantes. El genotipo 'MEN 186' mostró tener una actividad antioxidante superior a la 
de 'MEN 198'. A la hora de intentar establecer una relación entre la capacidad antioxidante y la recuperación y la estabilidad genética, nuestros resultados indicarían una relación inversa ya que en un estudio anterior se observó que el primero presenta menor recuperación y estabilidad genética después de la crioconservación que el segundo (ver capítulo 4, Martín et al. 2015). Sin embargo, para entender en su totalidad el sistema antioxidante presente en las plantas sería necesario estudiar, no sólo el contenido total de compuestos antioxidantes, sino también estudios que involucren la determinación de actividades de las enzimas antioxidantes (Gill y Tuteja 2010).

Que la capacidad antioxidante sea mayor en las hojas provenientes de cultivo in vitro que en las de invernadero podría ser una consecuencia de la adaptación que se produce en las plantas a las condiciones de estrés impuestas por el cultivo in vitro (p.e. medio, condiciones ambientales; Cassells y Curry 2001). Las muestras extraídas con PVP no contendrían compuestos fenólicos y alcaloides solubles, por lo que la capacidad antioxidante de las muestras de menta no se debe a compuestos fenólicos, sino a otro tipo de compuestos antioxidantes como ascorbato, poliaminas, y aminoácidos péptidos (glutatión) y proteínas con grupos tiol (Johnston et al. 2007).

Para tener una referencia de la capacidad antioxidante presente en otras especies, Pellegrini y col. (2006) realizaron una comparación utilizando el método ABTS en diferentes alimentos, entre éstos plantas herbáceas. Sus resultados fueron (en $\mu \mathrm{mol}_{\mathrm{ET}} / \mathrm{g}$ pf): 47,93 en laurel; 43,45 en romero: 30,65 en orégano: 30,51 en tomillo: 21,8 en albahaca: 8,84 menta y 7,9 en perejil. El resultado que obtuvieron en menta es similar a los valores obtenidos en nuestro estudio (entre 11 y $7 \mu \mathrm{mol}_{\mathrm{ET}} / \mathrm{g}$ pf en las plantas de invernadero), lo que nos indica que la capacidad antioxidante de los genotipos utilizados es relativamente baja, comparando con otras especies. Pellegrini también hace referencia a que el alto poder antioxidante del orégano y el romero es probablemente debido al extremadamente alto contenido de polifenoles, y otros ácidos hidroxicinámicos que poseen una fuerte actividad antioxidante.

En conclusión, los procesos oxidativos implicados en los diferentes pasos de los protocolos de crioconservación pueden ser responsables de la reducción en la supervivencia y recuperación de los tejidos y de cambios en la estabilidad genética antes y después de la exposición al nitrógeno líquido. Las técnicas utilizadas para la crioconservación imponen estrés en células que pueden causar daño, resultando en una reducción del crecimiento o muerte tras el calentamiento de los explantos. En el caso de la encapsulación-deshidratación 
de menta el uso de antioxidantes en la etapa "P" no mejora la supervivencia ni la estabilidad después de la crioconservación, aunque sí se pudo observar una reducción en la producción de de $\mathrm{O}_{2}{ }^{\circ}$. Cuando el ácido ascórbico se aplicaba en la etapa "S" ese descenso del radical libre fue también observable y la reducción de MDA fue muy significativa, indicando un menor daño oxidativo sobre las membranas celulares. Se aconsejaría la utilización de antioxidantes en la etapa "S" del procedimiento y evaluar su efecto en la recuperación y estabilidad del material crioconservado.

\subsection{Bibliografía}

Ai P-F, Lu L-P, Song J-J (2012) Cryopreservation of in vitro-grown shoot-tips of Rabdosia rubescens by encapsulation-dehydration and evaluation of their genetic stability. Plant Cell Tiss Organ Cult 108:381-387

Atmakuri AR, Chaudhury R, Malik SK, Kumar S, Ramachandran R, Qadri SMH (2009) Mulberry biodiversity conservation through cryopreservation. In Vitro Cell Dev Biol-Plant 45:639-649

Aust AE, Eveleigh JF (1999) Mechanisms of DNA oxidation. Experimental Biology and Medicine 222:246-252

Avello M y Suwalsky M (2006) Radicales libres antioxidantes naturales y mecanismos de protección. Atenea- II Sem. 494:161-172

Benson EE, Betsou F, Fuller BJ, Harding K, Kofanova O (2013) Translating cryobiology principles into trans-disciplinary storage guidelines for biorepositories and biobanks: a concept paper. CryoLetters 34:277-312

Bhattacharjee S (2011) Sites of generation and physicochemical basis of formation of reactive oxygen species in plant cell. In Gupta SD (ed.) Reactive oxygen species and antioxidants in higher plants. Science Publishers Enfield (USA), pp 1-30

Brul S, Nussbaum J, Dielbandhoesing SK (1997) Fluorescent probes for wall porosity and membrane integrity in filamentous fungi. Journal of Microbiological Methods 28:169-178 
Cassells AC, Curry RF (2001) Oxidative stress and physiological, epigenetic and genetic variability in plant tissue culture: implications for micropropagators and genetic engineers. Plant Cell Tiss Organ Cult 64:145-157

Castillo NRF, Bassil NV, Wada S, Reed BM (2010) Genetic stability of cryopreserved shoot tips of Rubus germplasm. In Vitro Cell Dev Biol-Plant 46:246-256

Cho EG, Hor YL, Kim HH, Rao VR, Engelmann F (2002) Cryopreservation of Citrus madurensis embryonic axes by encapsulation-dehydration. CryoLetters 23:325-332

Corpas FJ, Barroso JB, Carreras A, Quirós M, León AM, Romero-Puertas MC, Esteban FJ, Valderrama R, Palma JM, Sandalio LM, Gómez M, del Río LA (2004) Cellular and subcellular localization of endogenous nitric oxide in young and senescent pea plants. Plant Physiol 136:2722-2733

Corpas FJ, Barroso JB, Carreras A, Valderrama R, Palma JM, León AM, Sandalio LM, del Río LA (2006) Constitutive arginine-dependent nitric oxide synthase activity in different organs of pea seedlings during plant development. Planta 224: 246-254

Davey MW, Stals E, Panis B, Keulemans J, Swennen RL (2005) High-throughput determination of malondialdehyde in plant tissues. Analytical biochemistry 347:201-207

Dixit S, Mandal BB, Ahuja S, Srivastava PS (2003) Genetic stability assessment of plants regenerated from cryopreserved embryogenic tissues of Dioscorea bulbifera L. using RAPD, biochemical and morphological analysis. CryoLetters 24:77-84

Dumet D, Benson EE (2000) The use of physical and biochemical studies to elucidate and reduce cryopreservation-induced damage in hydrated/desiccated plant germplasm. En Engelmann F, Takagi H (eds.) Cryopreservation of Tropical Plant Germplasm - current research progress and applications. JIRCAS/IPGRI, Tsukuba (Japón)/Roma (Italia), pp. 43-56

Engelmann F (2004) Plant cryopreservation: progress and prospects. In Vitro Cell Dev Biol-Plant 40:427-433

Esterbauer H, Zollner H, Schaur RJ (1988) Hydroxyalkenals: cytotoxic products of lipid peroxidation. ISI Atlas Sci Biochem 1:311-317

Fink B, Laude K, McCann L, Doughan A, Harrison DG, Dikalov S (2004) Detection of intracellular superoxide formation in endothelial cells and intact tissues using 
dihydroethidium and an HPLC-based assay. American Journal of Physiology-Cell Physiology 287:895-902

Foyer CH (1993) Ascorbic acid. En: Alscher RG, Hess JL (eds.) Antioxidants in higher plants. CRC press, Florida, pp 31-58

Gawel NJ, Jarret RL (1991) A modified CTAB DNA extraction procedure for Musa and Ipomoea. Plant Molecular Biology Reporter 9:262-266

Gill SS, Tuteja N (2010) Reactive oxygen species and antioxidant machinery in abiotic stress tolerance in crop plants. Plant Physiology and Biochemistry 48:909-930

Gonzalez-Arnao MT, Engelmann F (2006) Cryopreservation of plant germplasm using the encapsulation-dehydration technique: review and case study on sugarcane. CryoLetters 27:155-168

Gonzalez-Arnaol MT, Urra C, Morenza M, Ríos A (1998) Cryopreservation of citrus apices using the encapsulation-dehydration technique. CryoLetters 19:177-182

Gutteridge J, Halliwell B (2000) Free radicals and antioxidants in the year 2000: a historical look to the future. Annals of the New York Academy of Sciences 899:136-147

Hao YJ, Liu QL, Deng XX (2001) Effect of cryopreservation on apple genetic resources at morphological, chromosomal, and molecular levels. Cryobiology 43:46-53

Hao YJ, You CX, Deng XX (2002) Analysis of ploidy and the patterns of amplified fragment length polymorphism and methylation sensitive amplified polymorphism in strawberry plants recovered from cryopreservation. CryoLetters 23:37-46

Harding K (2004) Genetic integrity of cryopreserved plant cells: a review. CryoLetters $25: 3-22$

Harding K, Benson EE (2000) The use of microsatellite analysis in Solanum tuberosum L. in vitro plantlets derived from cryopreserved germplasm. CryoLetters, 22:199-208

Hirai D, Sakai A 1999 Cryopreservation of in vitro-grown axillary shoot-tip meristems of mint (Mentha spicata L.) by encapsulation vitrification. Plant Cell Rep 19:150-155

Imlay JA (2003) Pathways of oxidative damage. Annual Reviews in Microbiology 57:395418 
Jaccard P (1908) Nouvelles recherches sur la distribution florale. Bull Soc Vaud Sci Nat $44: 223-270$

Johnston JW, Harding K, Benson EE (2007) Antioxidant status and genotypic tolerance of Ribes in vitro cultures to cryopreservation. Plant Science 172:524-534

Kaczmarczyk A, Rokka VM, Keller EJ (2011) Potato shoot tip cryopreservation. A review. Potato research 54:45-79

Kaity A, Ashmore SE, Drew RA (2009) Field performance evaluation and genetic integrity assessment of cryopreserved papaya clones. Plant cell Rep 28:1421-1430

Kaity A, Ashmore SE, Drew RA, Dulloo ME (2008) Assessment of genetic and epigenetic changes following cryopreservation in papaya. Plant cell Rep 27:1529-1539

Kojima H, Sakurai, K, Kikuchi K, Kawahara S, Kirino Y, Nagoshi H, Hirata Y, Nagano T (1998) Development of a fluorescent indicator for nitric oxide based on the fluorescein chromophore. Chemical and pharmaceutical bulletin 46:373-375

Li BQ, Feng CH, Wang MR, Hu LY, Volk G, Wang QC (2015) Recovery patterns, histological observations and genetic integrity in Malus shoot tips cryopreserved using droplet-vitrification and encapsulation-dehydration procedures. Journal of biotechnology 214:182-191

Mandal BB, Ahuja-Ghosh S, Srivastava PS (2008) Cryopreservation of Dioscorea rotundata Poir: a comparative study with two cryogenic procedures and assessment of true-totype of regenerants by RAPD analysis. CryoLetters. 29:399-408

Martín C, Cervera MT, González-Benito ME (2011) Genetic stability analysis of chrysanthemum (Chrysanthemum $\times$ morifolium Ramat) after different stages of an encapsulation-dehydration cryopreservation protocol. J Plant Physiol 168:158-66

Martín C, González-Benito ME (2005) Survival and genetic stability of Dendranthema grandiflora Tzvelev shoot apices after cryopreservation by vitrification and encapsulationdehydration. Cryobiology 51:281-289

Martín, C, Kremer C, González-Benito ME, González I (2015) Influence of the cryopreservation technique, recovery medium and genotype on genetic stability of mint cryopreserved shoot tips. Plant Cell Tiss Organ Cult 122:185-195 
Matsumoto T (2001) Cryopreservation of in vitro-cultured meristems of wasabi. In Engelmann F, Takagi H (eds.) Cryopreservation of Tropical Plant Germplasm - current research progress and applications. JIRCAS/IPGRI, Tsukuba (Japón)/Roma (Italia), pp 212216

Matsumoto T, Akihiro T, Maki S, Mochida K, Kitagawa M, Tanaka D, Yamamoto S, Niino T (2013) Genetic stability assessment of wasabi plants regenerated from long-term cryopreserved shoot tips using morphological biochemical and molecular analysis. CryoLetters 34:128-136

Mikuła A, Tomiczak K, Rybczyński JJ (2011) Cryopreservation enhances embryogenic capacity of Gentiana cruciata (L.) suspension culture and maintains (epi) genetic uniformity of regenerants. Plant cell Rep 30:565-574

Miñano HS, Ibáñez MA, González-Benito ME, Martín C (2014) Sequential study of the genetic stability of callus and regenerated shoots in chrysanthemum. Propag Ornam Plants 14:57-67

Nair DS, Reghunath BR (2009) Cryoconservation and regeneration of axillary shoot meristems of Indigofera tinctoria (L.) by encapsulation-dehydration technique. In Vitro Cell Dev Biol-Plant 45:565-573

Panis B, Lambardi M (2006) Status of cryopreservation technologies in plants (crops and forest trees). En: Ruane J, Sonnino A (eds.) The role of biotechnology for the characterization and conservation of crop forest animal and fishery genetic resources in developing countries Turin (Italia), pp 61-78

Pellegrini N, Serafini M, Salvatore S, Del Rio D, Bianchi M, Brighenti F (2006) Total antioxidant capacity of spices, dried fruits, nuts, pulses, cereals and sweets consumed in Italy assessed by three different in vitro assays. Molecular nutrition \& food research 50:1030-1038

Plastaras JP, Riggins JN, Otteneder M, Marnett LJ (2000) Reactivity and mutagenicity of endogenous DNA oxopropenylating agents: base propenals, malondialdehyde, and $\mathrm{N} \varepsilon$ oxopropenyllysine. Chemical research in toxicology 13:1235-1242

Plessis P, Leddet C, Dereuddre J (1991) Resistance to dehydration and to freezing in liquid nitrogen of alginate-coated shoot-tips of grape vine (Vitis vinifera L. cv. Chardonnay). C R Acad Sci 313:373-80 
Re R, Pellegrini N, Proteggente A, Pannala A, Yang M, Rice-Evans C (1999) Antioxidant activity applying an improved ABTS radical cation decolorization assay. Free radical biology and medicine 26:1231-1237

Ren L, Zhang D, Jiang X-N, Gai Y, Wang W-M, Reed BM, Shen X-H (2013) Peroxidation due to cryoprotectant treatment is a vital factor for cell survival in Arabidopsis cryopreservation. Plant Sci 212 (2013) 37- 47

Rodríguez-Serrano M, Romero-Puertas MC, Pazmiño DM, Testillano PS, Risueño MC, Luis A, Sandalio LM (2009) Cellular response of pea plants to cadmium toxicity: cross talk between reactive oxygen species, nitric oxide, and calcium. Plant Physiol 150:229-243

Rodríguez-Serrano M, Romero-Puertas MC, Zabalza A, Corpas FJ, Gómez M, Del Rio L, Sandalio LM (2006) Cadmium effect on oxidative metabolism of pea (Pisum sativum L.) roots. Imaging of reactive oxygen species and nitric oxide accumulation in vivo. Plant, Cell \& Environment 29:1532-1544

Rohlf FJ (1992) NTSYS-PC: numerical taxonomy and multivariate analysis system. Exeter Software, Nueva York

Sakai A, Engelmann F (2007) Vitrification, encapsulation-vitrification and dropletvitrification: a review. CryoLetters 28:151-172

Sakai A, Matsumoto T, Hirai D, Niino T (2000) Newly developed encapsulationdehydration protocol for plant cryopreservation. CryoLetters 21:53-62

Salaj T, Matušíková I, Fráterová L, Piršelová B, Salaj J (2011) Regrowth of embryogenic tissues of Pinus nigra following cryopreservation. Plant Cell Tiss Organ Cult 106:55-61

Sambrook J, Fritsch EF, Maniatis T (1989) Molecular cloning. Cold spring harbor laboratory press Nueva York, pp 14-95

Sangeeta A, Mandal BB, Dixit S, Srivastava PS (2002) Molecular, phenotypic and biosynthetic stability in Dioscorea floribunda plants derived from cryopreserved shoot tips. Plant Science 163:971-977

Senula A, Keller J, Sanduijav T, Yohannes T (2007) Cryopreservation of cold-acclimated mint (Mentha spp.) shoot tips using a simple vitrification protocol. CryoLetters 28:1-12 
Srivastava V, Khan SA, Banerjee S (2009) An evaluation of genetic fidelity of encapsulated microshoots of the medicinal plant: Cineraria maritima following six months of storage. Plant Cell Tiss Organ Cult 99:193-198

Takahama U (1988) Oxidation of flavonoids by hydrogen peroxide in epidermal and guard cells of Vicia faba L. Plant Cell Physiol 29: 433-438

Teixeira AS, González-Benito ME, Molina-García AD (2014) Determination of glassy state by cryo-SEM and DSC in cryopreservation of mint shoot tips by encapsulationdehydration. Plant Cell Tiss Organ Cult 119:269-280

Turner S, Krauss SL, Bunn E, Senaratna T, Dixon K, Tan B, Touchell D (2001) Genetic fidelity and viability of Anigozanthos viridis following tissue culture, cold storage and cryopreservation. Plant Science 161:1099-1106

Uchendu EE, Leonard SW, Traber MG, Reed BM (2010a) Vitamins C and E improve regrowth and reduce lipid peroxidation of blackberry shoot tips following cryopreservation. Plant Cell Rep 29:25-35

Uchendu EE, Muminova M, Gupta S, Reed BM (2010b) Antioxidant and anti-stress compounds improve regrowth of cryopreserved Rubus shoot tips. In Vitro Cell Dev Biol-Plant 46:386-393

Uchendu EE, Reed BM (2008) A comparative study of three cryopreservation protocols for effective storage of in vitro grown mint (Mentha spp.). CryoLetters 29: 181-188

Uchendu EE, Shukla MR, Reed BM, Saxena PK (2013) Melatonin enhances the recovery of cryopreserved shoot tips of American elm (Ulmus americana L.). Journal of pineal research 55:435-442

van den Berg R, Haenen GR, van den Berg H, van der Vijgh W, Bast A (2000) The predictive value of the antioxidant capacity of structurally related flavonoids using the Trolox equivalent antioxidant capacity (TEAC) assay. Food Chemistry 70:391-395

Vasconcelos Franco JS, Chaveiro A, da Silva FM (2014) Effect of Freezing Rates and Supplementation of $\alpha$-Tocopherol in the Freezing Extender in Equine Sperm Cryosurvival. Journal of Equine Veterinary Science 34:992-997 
Vos P, Hogers R, Bleeker M, Reijans M, van de Lee T, Hornes M, Friters A, Pot J, Paleman J, Kuiper M, Zabeau M (1995) AFLP: a new technique for DNA fingerprinting. Nucleic acids research 23:4407-4414

Wang ZC, Deng XX (2004) Cryopreservation of shoot-tips of citrus using vitrification: effect of reduced form of glutathione. CryoLetters 25:43-50

Yamauchi Y, Furutera A, Seki K, Toyoda Y, Tanaka K, Sugimoto Y (2008) Malondialdehyde generated from peroxidized linolenic acid causes protein modification in heat-stressed plants. Plant Physiol Biochem 46:786-793

Zeliang PK, Pattanayak A, Iangrai B, Khongwir EA, Sarma BK (2010) Fertile plant regeneration from cryopreserved calli of Oryza rufipogon Griff. and assessment of variation in the progeny of regenerated plants. Plant Cell Rep 29:1423-1433

Zhai Z, Wu Y, Engelmann F, Chen R, Zhao Y (2003) Genetic stability assessments of plantlets regenerated from cryopreserved in vitro cultured grape and kiwi shoot-tips using RAPD. CryoLetters, 24:315-322

Zhao Y, Wu Y, Engelmann F, Zhou M, Zhang D, Chen S (1999) Cryopreservation of apple shoot tips by encapsulation-dehydration: effect of preculture, dehydration and freezing procedure on shoot regeneration. Cryo-letters 20:121-130 


\section{DISCUSIÓN GENERAL}

\subsection{Discusión}

La conservación a ultra baja temperatura o crioconservación es una estrategia desarrollada para el mantenimiento de material vegetal a largo plazo en condiciones que aseguren su conservación en el tiempo, y donde se evitan los problemas provocados por una excesiva manipulación y por la posible aparición de variaciones genéticas del material conservado in vitro. Se han desarrollado diversas técnicas de crioconservación, las cuales se basan en la realización de pretratamientos que disminuyen el contenido de agua congelable de las células y minimizan los posibles daños causados por la deshidratación. De esta manera se evita el daño derivado de la formación de cristales de hielo (Panis y Lambardi, 2005) durante la inmersión en el nitrógeno líquido y posteriormente en el calentamiento de los tejidos para su recuperación. Son técnicas sencillas y con un coste de mantenimiento relativamente menor al cultivo in vitro (Engelmann 2004) y que mantendrían la estabilidad genética del material conservado.

En el caso de la menta se han desarrollado con éxito diversos protocolos de crioconservación: enfriamiento controlado (Towill 1988), vitrificación (Towill 1990), encapsulación-deshidratación (Hirai y Sakai 1999), encapsulación vitrificación (Sakai et al. 2000), vitrificación-droplet (Senula et al. 2007) y vitrificación en cryo-plates (Yamamoto et al. 2012).

En general, los estudios de crioconservación realizados en menta, hasta la fecha, describen resultados basados en la recuperación de los explantos tras los diferentes procedimientos o en comparación de técnicas y pretratamientos, pero no se describen estudios en la estabilidad genética. En otras especies sí se han publicado resultados del estado genético del material vegetal en la crioconservación, de los cuales algunos no encuentran variación (Turner et al. 2001; Nair y Reghunath 2009; Castillo et al. 2010; Matsumoto 2013); o detectan pequeñas variaciones (Martín y González-Benito 2005; Kaity et al. 2008 y 2009; Martín et al. 2011). Los estudios presentados en este trabajo estudian las diferencias tanto en la recuperación de los explantos tratados, como en la estabilidad genética entre genotipos, técnicas de crioconservación, medios de recuperación y en el uso de antioxidantes durante el pretratamiento. 
El primer objetivo fue determinar si la técnica de crioconservación, con diferentes metodologías para la eliminación del agua congelable de los tejidos, podría afectar la respuesta de dos genotipos de menta ('MEN 186’ y 'MEN 198'). Las técnicas fueron la encapsulación-deshidratación donde se realiza una deshidratación osmótica y física de los tejidos y la vitrificación-droplet, que lo realiza mediante una deshidratación y osmoprotección basada en la utilización de la solución crioprotectora “PVS2”. La técnica de crioconservación utilizada no tuvo efecto en la tasa de recuperación de los ápices crioconservados. En vitrificación-droplet se alcanzó una recuperación en las muestras control del tratamiento (no sometidas a nitrógeno líquido, “NL-”) del 85-100 \%, en cambio en encapsulacióndeshidratación fue menor al 55 \%. Esta diferencia entre las técnicas de crioconservación, también se observa en el estudio de la estabilidad genética tras cuatro semanas de recuperación, donde el genotipo 'MEN 186' en vitrificación-droplet presenta el 90 \% de las muestras estables, agrupadas junto al control in vitro, sin embargo, ninguna muestra de encapsulación-deshidratación pertenece a ese agrupamiento. En el experimento donde se evaluó sólo la técnica de encapsulación-deshidratación a las 8 semanas de recuperación, se encontró una disminución de la estabilidad genética en ambos genotipos, y no hubo diferencias entre aquellos crioconservados de los que no fueron introducidos en NL. Todos estos datos nos indican que la inmersión en NL no es el único factor que podría provocar lesiones en el material crioconservado, sino que los pasos previos también estarían ejerciendo algún tipo de daño. La encapsulación-deshidratación también ha demostrado tener efectos negativos en publicaciones anteriores, como el estudio de la estabilidad genética de crisantemo (Martín y González-Benito, 2005) donde se encontró inestabilidad, sin embargo, en el protocolo de vitrificación no se detectó variación. En la encapsulación-deshidratación de Rabdosia rubescens (Ai et al. 2012) se encontraron pequeñas variaciones genéticas y diferencias en la capacidad de recuperación de los explantos. La estabilidad genética en la vitrificación ha sido descrita en diversos estudios. Las plantas regeneradas a partir de ápices vitrificados de Dioscorea floribunda (Ahuja et al. 2002) fueron estables a nivel molecular (RAPD). Liu y col. (2004, 2008) no encontraron diferencias entre el control y ápices de manzano vitrificados, tanto en características morfológicas y bioquímicas como moleculares (RAPD y AFLP). En la vitrificación-droplet de ápices de Petunia $\times$ hybrida (Zhang et al. 2015) de diferentes edades de cultivo in vitro, se compararon algunos cambios en pasos del protocolo, como la concentración de sacarosa en la solución de precultivo, la duración del precultivo, la duración de la osmoprotección, la duración de la exposición y la concentración de la solución PVS2 y el medio de recuperación. No encontraron diferencias morfológicas 
entre la planta madre y los ápices crioconservados, ni diferencias moleculares (SSR y AFLP) en ninguna combinación de tratamientos.

Mediante el uso de marcadores moleculares se detectó una respuesta genotipo-dependiente frente a técnicas de crioconservación similares. En el caso del análisis con marcadores RAPD a las 4 y 8 semanas de recuperación de los ápices tras su crioconservación, el genotipo 'MEN 198' presentó una mayor estabilidad que 'MEN 186' en ambas técnicas. Posteriormente, en el estudio del efecto de antioxidantes en la estabilidad genética mediante marcadores AFLP (al 95\% de similitud), también se observó una mayor estabilidad en 'MEN 198' que en 'MEN 186’. Siendo el porcentaje de muestras estables el 92 \% y 50 \% respectivamente. En un estudio anterior (Martín et al. 2013) ya se había descrito la estabilidad del genotipo 'MEN 198' tanto en muestras de una colección de campo, en material conservado in vitro (en crecimiento lento) y en el crioconservado por vitrificación-droplet. Este comportamiento diferente entre genotipos se ha descrito previamente en el estudio genético tras la crioconservación de Pyrus spp. (Reed 1990), Carica papaya (Kaity et al. 2013) y en Ribes spp. (Reed y Xu 1995).

Cuando se compararon tres medios de recuperación y técnicas de crioconservación diferentes en 'MEN 186' y 'MEN 198' se observó un efecto positivo en la utilización del medio "Reed" en la supervivencia y la recuperación de los ápices crioconservados mediante encapsulación-deshidratación y en la recuperación de los crioconservados por vitrificacióndroplet, en ambos genotipos. La diferencia de este medio con los otros (“Nudos” y "Senula”) es la ausencia de auxinas, lo cual además de provocar un aumento en la supervivencia, redujo la formación de callo en los ápices recuperados. La formación de callo durante la recuperación de los explantos es indeseable puesto que su formación aumenta potencialmente la frecuencia de variación genética (Sakai y Engelmann 2007). Chang y Reed (2008) obtuvieron similares resultados en dos genotipos de Rubus spp. crioconservados por enfriamiento controlado. Al eliminar las auxinas del medio de recuperación se disminuyó la formación de callo en ambos genotipos. Bachiri y col. (2001) en la encapsulacióndeshidratación de ápices de Actinidia spp. obtuvieron una mayor recuperación utilizando una combinación de citoquininas y zeatina, y eliminando las auxinas.

El medio de recuperación utilizado también tuvo un efecto en la estabilidad de los ápices crioconservados por encapsulación-deshidratación en el genotipo más inestable, 'MEN 186', 
donde se obtuvo una mayor estabilidad en todos los tipos de muestras analizados que habían sido recuperados en el medio "Senula”.

El tipo de muestra analizada también mostró diferencias en la estabilidad genética en todos los ensayos realizados. Con estos resultados se confirma, tal como se ha descrito anteriormente, que la formación de callo es un suceso indeseable en la recuperación de los ápices, que puede provocar una mayor variabilidad genética, aunque también se pueden obtener callos estables como se ha visto en algunos casos, por ejemplo, en el estudio comparativo de medios de regeneración en algunas las muestras de callos del genotipo 'MEN 186 .

En la crioconservación, la respuesta negativa de los genotipos tratados (disminución en la capacidad de recuperación o variabilidad genética) se ha correlacionado con el daño oxidativo sobre los tejidos asociado al procedimiento. Este daño es provocado cuando el nivel de generación de especies reactivas del oxígeno (ROS) es mayor que la capacidad antioxidante presente en las células. Es posible que exista una acumulación de estreses provocados durante el procedimiento de crioconservación, tales como los causados por la escisión o la deshidratación. Este estrés y daño oxidativo resultantes pueden ser los responsables de la reducción de la viabilidad de los tejidos después de la exposición a nitrógeno líquido y calentamiento.

Para conseguir disminuir el daño por estrés oxidativo se han publicado los efectos positivos de la adición de antioxidantes en diversas etapas de la crioconservación en algunas especies (Reed et al. 2014). Por ejemplo, se observó una mejora en la recuperación después de la crioconservación por vitrificación en ápices de Citrus con la utilización de glutatión (Wang y Deng 2004), y con el uso de melatonina en olmo y tabaco (Uchendu et al. 2013, 2014). Los antioxidantes seleccionados en este estudio fueron vitamina $\mathrm{E}$ ( $\alpha$ tocoferol),ácido ascórbico y glutatión. La utilización de estos antioxidantes en el precultivo de ápices en el protocolo de encapsulación-deshidratación no provocaron diferencias en la recuperación de los ápices tras su crioconservación. Sólo el uso de vitamina E aumentó la recuperación en el estudio de los pasos de la encapsulación-deshidratación de los ápices en la etapa de deshidratación física de 'MEN 198'. Estos resultados no coinciden con los obtenidos por Uchendu y col. (2010a) en Rubus, sin embargo, la técnica de crioconservación utilizada es diferente (vitrificación). Tampoco se encontraron efectos de la utilización de antioxidantes en la estabilidad genética 
en la mayoría de las muestras, sólo en el genotipo 'MEN 186' la estabilidad fue más alta con el uso de vitamina E.

En el análisis secuencial tras cada etapa del proceso de crioconservación por encapsulación-deshidratación en el genotipo de menta 'MEN 198', se observó que la variabilidad genética aparece en la etapa de precultivo de los ápices, la cual va aumentando al avanzar en el procedimiento hasta la inmersión en NL. Una respuesta similar se observó en el estudio de la encapsulación-deshidratación en crisantemo (Martín et al. 2011). Estos datos se pueden correlacionar con los estudios de ROS y MDA, donde se detectó la presencia del radical $\mathrm{O}_{2}{ }^{--}$a partir de la etapa de preaclimatación de los segmentos nodales a temperaturas alternas y un fuerte aumento de la producción de malondialdehído en la etapa de deshidratación osmótica. El aumento del estrés oxidativo provocaría un descenso de la estabilidad genética, en este caso asociado al estrés osmótico que ejerce la sacarosa, lo que se ha observado en el estudio de encapsulación-deshidratación en crisantemo (Martín et al. 2011). Esto datos confirman la hipótesis de que los pasos previos o pretratamientos antes de la inmersión en NL provocan estrés oxidativo en los tejidos y por consiguiente se producirían daños en las células y, posiblemente, al ADN.

En el caso de la cuantificación de la presencia de MDA y $\mathrm{O}_{2}{ }^{\circ-}$, el efecto de la adición de antioxidantes fue muy significativo en la etapa de deshidratación osmótica, paso en el que se producía la mayor señal de estrés sin la adición de ác. ascórbico, disminuyendo dichos valores. En el caso del uso de antioxidante en el precultivo de ápices no hubo efectos en la formación de MDA, sí en el caso del $\mathrm{O}_{2}{ }^{\circ-}$ que disminuyó en comparación al control sin antioxidantes. En cambio, Uchendu y col. (2010a) utilizando sustancias antioxidantes en la crioconservación (por vitrificación) de Rubus observaron una reducción significativa de MDA en todas las etapas estudiadas. No se han encontrado estudios que analicen el efecto de los antioxidantes en la encapsulación deshidratación, sólo en aquellos que utilizan la vitrificación. La capacidad antioxidante observada en los genotipos de menta en este estudio fue relativamente baja, lo cual también se ha descrito anteriormente (Pellegrini et al. 2007). 


\subsection{Bibliografía}

Ahuja S, Mandal BB, Dixit S, Srivastava PS (2002) Molecular, phenotypic and biosynthetic stability in Dioscorea floribunda plants derived from cryopreserved shoot tips. Plant Science 163:971-977

Ai P-F, Lu L-P, Song J-J (2012) Cryopreservation of in vitro-grown shoot-tips of Rabdosia rubescens by encapsulation-dehydration and evaluation of their genetic stability. Plant Cell Tiss Organ Cult 108:381-387

Bachiri Y, Song GQ, Plessis P, Shoar-Ghaffari A, Rekab T, Morisset C (2001) Routine cryopreservation of kiwifruit (Actinidia spp) germplasm by encapsulation-dehydration: Importance of plant growth regulators. CryoLetters 22:61-74

Benson, EE (1990) Free radical damage in stored plant germplasm. International board for plant genetic resources, Roma.

Castillo NRF, Bassil NV, Wada S, Reed BM (2010) Genetic stability of cryopreserved shoot tips of Rubus germplasm. In Vitro Cell Dev Biol-Plant 46:246-256

Davey MW, Franck C, Keulemans J (2004) Distribution, developmental and stress responses of antioxidant metabolism in Malus. Plant Cell Environ 27:1309-1320

Dumet D, Benson EE (2000) The use of physical and biochemical studies to elucidate and reduce cryopreservation-induced damage in hydrated/desiccated plant germplasm. En Engelmann F, Takagi H (eds.) Cryopreservation of Tropical Plant Germplasm - current research progress and applications. JIRCAS/IPGRI, Tsukuba (Japón)/Roma (Italia), pp. 43-56

Engelmann F (2004) Plant cryopreservation: progress and prospects. biodiversity In Vitro Cell Dev Biol-Plant 40:427-433

Esterbauer H, Zollner H, Schaur RJ (1988) Hydroxyalkenals: cytotoxic products of lipid peroxidation. ISI Atlas Sci Biochem 1:311-317

Hirai D, Sakai A (1999) Cryopreservation of in vitro-grown axillary shoot-tip meristems of mint (Mentha spicata L.) by encapsulation-vitrification. Plant Cell Reports 19:150-155 
Jokipii S, Ryynänen L, Kallio PT, Aronen T, Häggman H (2004) A cryopreservation method maintaining the genetic fidelity of a model forest tree, Populus tremula L.× Populus tremuloides Michx. Plant Science 166:799-806

Kaity A, Ashmore SE, Drew RA (2009) Field performance evaluation and genetic integrity assessment of cryopreserved papaya clones. Plant cell Rep 28:1421-1430

Kaity A, Ashmore SE, Drew RA, Dulloo ME (2008) Assessment of genetic and epigenetic changes following cryopreservation in papaya. Plant cell Rep 27:1529-1539

Kaity A, Drew RA, Ashmore SE (2013) Genetic and epigenetic integrity assessment of acclimatized papaya plants regenerated directly from shoot-tips following short- and longterm cryopreservation. Plant Cell Tiss Organ Cult 112:75-86

Liu Y, Wang X, Liu L (2004) Analysis of genetic variation in surviving apple shoots following cryopreservation by vitrification. Plant Science 166: 677-685

Liu YG, Liu LX, Wang L, Gao AY (2008) Determination of genetic stability in surviving apple shoots following cryopreservation by vitrification. CryoLetters 29:7-14

Martín C, Cerverab MT, González-Benito ME (2011) Genetic stability analysis of chrysanthemum (Chrysanthemum $x$ morifolium Ramat) after different stages of an encapsulation-dehydration cryopreservation protocol. J Plant Physiol 168:158-166

Martín C, González-Benito ME (2005) Survival and genetic stability of Dendranthema grandiflora Tzvelev shoot apices after cryopreservation by vitrifcation and encapsulationdehydration. Cryobiology 51: 281-289

Martín C, Senula A, González I, Acosta A, Keller ERJ, González-Benito ME (2013) Genetic identity of three mint accessions stored by different conservation procedures: field collection in vitro and cryopreservation. Genet Resour Crop Evol 60:243-249

Matsumoto T, Akihiro T, Maki S, Mochida K, Kitagawa M, Tanaka D, Yamamoto S, Niino T (2013) Genetic stability assessment of wasabi plants regenerated from long-term cryopreserved shoot tips using morphological biochemical and molecular analysis. CryoLetters 34:128-136 
Nair DS, Reghunath BR (2009) Cryoconservation and regeneration of axillary shoot meristems of Indigofera tinctoria (L.) by encapsulation-dehydration technique. In Vitro Cell Dev Biol-Plant 45:565-573

Panis B, Lambardi M (2006) Status of cryopreservation technologies in plants (crops and forest trees. En: Ruane J, Sonnino A (eds) The role of biotechnology for the characterization and conservation of crop forest animal and fishery genetic resources in developing countries. Roma (Italia), pp 61-78

Pellegrini N, Serafini M, Salvatore S, Del Rio D, Bianchi M, Brighenti F (2006) Total antioxidant capacity of spices, dried fruits, nuts, pulses, cereals and sweets consumed in Italy assessed by three different in vitro assays. Molecular nutrition \& food research 50:1030-1038

Reed BM (1990) Survival of in vitro-grown apical meristems of Pyrus following cryopreservation. HortScience 25:111-113

Reed BM (2014) Antioxidants and cryopreservation, the new normal? Acta Hort 1039: 4148

Reed BM, Hummer KE, Gupta S, Chang Y (2008) Medium and long-term storage of Rubus germplasm. En Bañados P, Dale A (eds.) IX International Rubus and Ribes Symposium. Acta Hort. 777:91-98

Reed BM, Yu X (1995) Cryopreservation of in vitro-grown gooseberry and currant meristems. CryoLetters 16:131-136

Sakai A, Engelmann F (2007) Vitrification, encapsulation-vitrification and dropletvitrification: a review. CryoLetters 28:151-172

Sakai A, Matsumoto T, Hirai D, Niino T (2000) Newly development encapsulationdehydration protocol for plant cryopreservation. CryoLetters 21:53-62

Senula A, Keller J, Sanduijav T, Yohannes T (2007) Cryopreservation of cold-acclimated mint (Mentha spp.) shoot tips using a simple vitrification protocol. CryoLetters 28: 1-12

Towill LE (1988) Survival of shoot tips from mint species after short-term exposure to cryogenic conditions. HortScience 23: 839-841 
Towill LE (1990) Cryopreservation of isolated mint shoot tips by vitrification. Plant Cell Reports 9:178-180

Turner S, Krauss SL, Bunn E, Senaratna T, Dixon K, Tan B, Touchell D (2001) Genetic fidelity and viability of Anigozanthos viridis following tissue culture cold storage and cryopreservation. Plant Science 161:1099-1106

Uchendu EE, Leonard SW, Traber MG, Reed BM (2010a) Vitamins C and E improve regrowth and reduce lipid peroxidation of blackberry shoot tips following cryopreservation. Plant Cell Rep 29:25-35

Uchendu EE, Muminova M, Gupta S, Reed BM (2010b) Antioxidant and anti-stress compounds improve regrowth of cryopreserved Rubus shoot tips. In Vitro Cell Dev Biol-Plant 46:386-393

Uchendu EE, Shukla MR, Reed BM, Saxena PK (2013) Melatonin enhances the recovery of cryopreserved shoot tips of American elm (Ulmus americana L.). Journal of pineal research 55:435-442

Uchendu EE, Shukla MR, Reed BM, Saxena PK (2014) An efficient method for cryopreservation of St John's Wort and tobacco: role of melatonin. Acta Hort 1039: 233-241

Wang ZC, Deng XX (2004) Cryopreservation of shoot-tips of citrus using vitrification: effect of reduced form of glutathione. CryoLetters 25:43-50

Yamamoto S, Rafique T, Fukui K, Sekizawa K, Niino T (2012) V-cryo-plate procedure as an effective protocol for cryobanks: case study of mint cryopreservation. CryoLetters 33:1223

Zhang JM, Huang B, Zhang XN, Volk GM, Zhou YC, Chen XL (2015) Identification of a highly successful cryopreservation method (droplet-vitrification) for petunia. In Vitro Cell Dev Biol-Plant 36:163-170 51:445-451 


\section{CONCLUSIONES}

1. Las técnicas de crioconservación ensayadas en ápices de dos genotipos ('MEN 186' y 'MEN198') de Mentha x piperita L. presentan diferencias significativas en la estabilidad genética de los explantos recuperados. Para los dos genotipos la estabilidad genética es mayor con el uso del protocolo de vitrificación-droplet que con el de encapsulación-deshidratación.

2. La pérdida de estabilidad genética ocurre tanto en las etapas previas a la inmersión en nitrógeno líquido como al finalizar el proceso de crioconservación, lo cual sugiere que la inmersión en nitrógeno líquido no es per se la principal fuente de inestabilidad asociada a la crioconservación.

3. La composición de los medios de recuperación ensayados no parece tener un efecto significativo en la estabilidad genética del material crioconservado, si bien, sí se aprecia una mayor recuperación de los ápices con el empleo del medio sin auxinas ("Reed").

4. Se observa una clara influencia del genotipo en el grado de estabilidad genética obtenido tras la crioconservación: el genotipo 'MEN 198' resulta más estable que 'MEN 186’en ambas técnicas de crioconservación estudiadas.

5. El tipo de muestra analizado presenta diferencias significativas en su estabilidad genética. Las muestras correspondientes a hojas de brotes recuperados presentan una mayor estabilidad que aquellos ápices que formaron callo.

6. La utilización de los antioxidantes (ácido ascórbico, glutatión y vitamina E), en el precultivo de ápices del protocolo de encapsulación-deshidratación no supone una mejora en la recuperación de los ápices en comparación con el tratamiento control. Sin embargo, el uso de vitamina E aumenta la estabilidad genética del genotipo 'MEN 186'.

7. A través del estudio secuencial por pasos del protocolo de encapsulación-deshidratación se observa una disminución gradual a lo largo del protocolo de la capacidad de recuperación y de la estabilidad genética en los ápices.

8. Así mismo, en el estudio de cada paso de la encapsulación-deshidratación se ha encontrado una correlación entre la presencia de compuestos indicadores del estrés y 
daño oxidativo y la pérdida de capacidad de recuperación y la inestabilidad de los ápices. En concreto, a medida que se avanza en el proceso aumenta la concentración de malondialdehido (MDA) y radical superóxido $\left(\mathrm{O}_{2}{ }^{*}\right)$.

9. El efecto de la adición de antioxidantes en la etapa de deshidratación osmótica en el protocolo de encapsulación-deshidratación influye significativamente en el descenso de los niveles oxidativos, representados por la producción de de MDA y $\mathrm{O}_{2}{ }^{*-}$, indicando que el uso de antioxidantes parece más adecuado en esta etapa. 


\section{ANEXOS}

\section{Anexo I. Análisis estadístico de la recuperación de ápices en estudio secuencial (datos en Fig. 6.1)}

Tabla 9.1. ANOVA del efecto de la adición de antioxidantes en la etapa "P" en la supervivencia de ápices ‘MEN 198’ a las 4 semanas de recuperación.

\begin{tabular}{lccccc}
\hline Fuente & $\begin{array}{c}\text { Suma de } \\
\text { cuadrados }\end{array}$ & gl & $\begin{array}{c}\text { Media } \\
\text { cuadrática }\end{array}$ & F & Significación \\
\hline Etapa/tratamiento & $3383,856 a$ & 13 & 260,297 & 1,899 &, 046 \\
Error & 9185,700 & 67 & 137,100 & & \\
\hline
\end{tabular}

Tabla 9.2. ANOVA del efecto de la adición de antioxidantes en la etapa "P" en la regeneración de ápices 'MEN 198' a las 4 semanas de recuperación.

\begin{tabular}{lccccc}
\hline Fuente & $\begin{array}{c}\text { Suma de } \\
\text { cuadrados }\end{array}$ & gl & $\begin{array}{c}\text { Media } \\
\text { cuadrática }\end{array}$ & F & Significación \\
\hline Etapa/tratamiento & $31835,756 a$ & 13 & 2448,904 & 13,809 &, 000 \\
Error & 11881,800 & 67 & 177,340 & & \\
\hline
\end{tabular}

Tabla 9.3. ANOVA del efecto de la adición de antioxidantes en la etapa "P” en la supervivencia de ápices 'MEN 198' a las 8 semanas de recuperación.

\begin{tabular}{lccccc}
\hline Fuente & $\begin{array}{c}\text { Suma de } \\
\text { cuadrados }\end{array}$ & gl & $\begin{array}{c}\text { Media } \\
\text { cuadrática }\end{array}$ & F & Significación \\
\hline Etapa/tratamiento & $4469,608 \mathrm{a}$ & 13 & 343,816 & 2,908 &, 002 \\
Error & 7922,396 & 67 & 118,245 & & \\
\hline
\end{tabular}

Tabla 9.4. ANOVA del efecto de la adición de antioxidantes en la etapa “P” en la regeneración de ápices 'MEN 198' a las 8 semanas de recuperación.

\begin{tabular}{lccccc}
\hline Fuente & $\begin{array}{c}\text { Suma de } \\
\text { cuadrados }\end{array}$ & gl & $\begin{array}{c}\text { Media } \\
\text { cuadrática }\end{array}$ & F & Significación \\
\hline Etapa/tratamiento & $28385,294 a$ & 13 & 2183,484 & 9,483 &, 000 \\
Error & 15427,035 & 67 & 230,254 & & \\
\hline
\end{tabular}


Anexo II. Análisis estadístico del efecto de la utilización de antioxidantes en etapa “P” en la formación de callo en pasos " $S$ ", “ $D$ " $y$ “Cr" de la encapsulación-deshidratación (datos en Tabla 6.2)

Tabla 9.5. Regresión logística para datos binarios de la formación de callos en la etapa “S” .

\begin{tabular}{ccc}
\hline Chi-cuadrado de Wald & gl & Sig. \\
\hline 2.154 & 2 & .341 \\
\hline
\end{tabular}

Tabla 9.6. Regresión logística para datos binarios de la formación de callos en la etapa “D”.

\begin{tabular}{ccc}
\hline Chi-cuadrado de Wald & gl & Sig. \\
\hline 2.962 & 2 & .227 \\
\hline
\end{tabular}

Tabla 9.7. Regresión logística para datos binarios de la formación de callos en la etapa “Cr”.

\begin{tabular}{ccc}
\hline Chi-cuadrado de Wald & gl & Sig. \\
\hline 10.956 & 2 & .004
\end{tabular}

III. Análisis estadístico de la estabilidad genética con marcadores moleculares RAPDs, efecto de la utilización de antioxidantes en etapa “P” en cada paso de la encapsulación-deshidratación (datos en Tabla 6.3)

Tabla 9.8. Regresión logística para datos binarios de la estabilidad genética con marcadores RAPD al $100 \%$ de similitud en etapa “P”.

\begin{tabular}{ccc}
\hline Chi-cuadrado de Wald & gl & Sig. \\
\hline 1.167 & 2 & .558 \\
\hline
\end{tabular}


Tabla 9.9. Regresión logística para datos binarios de la estabilidad genética con marcadores al $100 \%$ de similitud en etapa "S".

\begin{tabular}{ccc}
\hline Chi-cuadrado de Wald & gl & Sig. \\
\hline 2.333 & 2 & .311 \\
\hline
\end{tabular}

Tabla 9.10. Regresión logística para datos binarios de la estabilidad genética con marcadores RAPD al $100 \%$ de similitud en etapa "D”.

\begin{tabular}{ccc}
\hline Chi-cuadrado de Wald & gl & Sig. \\
\hline 5.993 & 2 & .050 \\
\hline
\end{tabular}

Tabla 9.11. Regresión logística para datos binarios de la estabilidad genética con marcadores RAPD al $100 \%$ de similitud en etapa “Cr”.

\begin{tabular}{ccc}
\hline Chi-cuadrado de Wald & gl & Sig. \\
\hline 4.583 & 2 & .101
\end{tabular}

\section{Anexo IV. Análisis estadístico de estabilidad genética con marcadores moleculares AFLPs, efecto de la utilización de antioxidantes en etapa "P” en cada paso de la encapsulación-deshidratación (datos en Tabla 6.5)}

Tabla 9.12. Regresión logística para datos binarios de la estabilidad genética con marcadores AFLP al 100 \% de similitud en etapa “P”.

\begin{tabular}{ccc}
\hline Chi-cuadrado de Wald & gl & Sig. \\
\hline .636 & 2 & .727 \\
\hline
\end{tabular}


Tabla 9.13. Regresión logística para datos binarios de la estabilidad genética con marcadores AFLP al 100 \% de similitud en etapa "S".

\begin{tabular}{ccc}
\hline Chi-cuadrado de Wald & gl & Sig. \\
\hline 4.200 & 2 & .122 \\
\hline
\end{tabular}

Tabla 9.14. Regresión logística para datos binarios de la estabilidad genética con marcadores AFLP al 100 \% de similitud en etapa “D”.

\begin{tabular}{ccc}
\hline Chi-cuadrado de Wald & gl & Sig. \\
\hline 17.500 & 2 & .000 \\
\hline
\end{tabular}

Tabla 9.15. Regresión logística para datos binarios de la estabilidad genética con marcadores AFLP al 100 \% de similitud en etapa "Cr".

\begin{tabular}{ccc}
\hline Chi-cuadrado de Wald & gl & Sig. \\
\hline 2.333 & 2 & .311
\end{tabular}

Tabla 9.16. Regresión logística para datos binarios de la estabilidad genética con marcadores AFLP al 95 \% de similitud en etapa “P”.

\begin{tabular}{ccc}
\hline Chi-cuadrado de Wald & gl & Sig. \\
\hline 3.967 & 2 & .138 \\
\hline
\end{tabular}

Tabla 9.17. Regresión logística para datos binarios de la estabilidad genética con marcadores AFLP al 95 \% de similitud en etapa "S".

\begin{tabular}{ccc}
\hline Chi-cuadrado de Wald & gl & Sig. \\
\hline 3.967 & 2 & .138 \\
\hline
\end{tabular}


Tabla 9.18. Regresión logística para datos binarios de la estabilidad genética con marcadores AFLP al $95 \%$ de similitud en etapa “D”

\begin{tabular}{ccc}
\hline Chi-cuadrado de Wald & gl & Sig. \\
\hline 5.800 & 2 & .055 \\
\hline
\end{tabular}

Tabla 9.19. Regresión logística para datos binarios de la estabilidad genética con marcadores AFLP al 95 \% de similitud en etapa “Cr”

\begin{tabular}{ccc}
\hline Chi-cuadrado de Wald & gl & Sig. \\
\hline 5.327 & 2 & .050 \\
\hline
\end{tabular}

\section{Anexo V. Imágenes producción de ROS y NO en pasos de la encapsulación-deshidratación y efecto de la utilización de antioxidantes en etapas "P" 0 "S"}
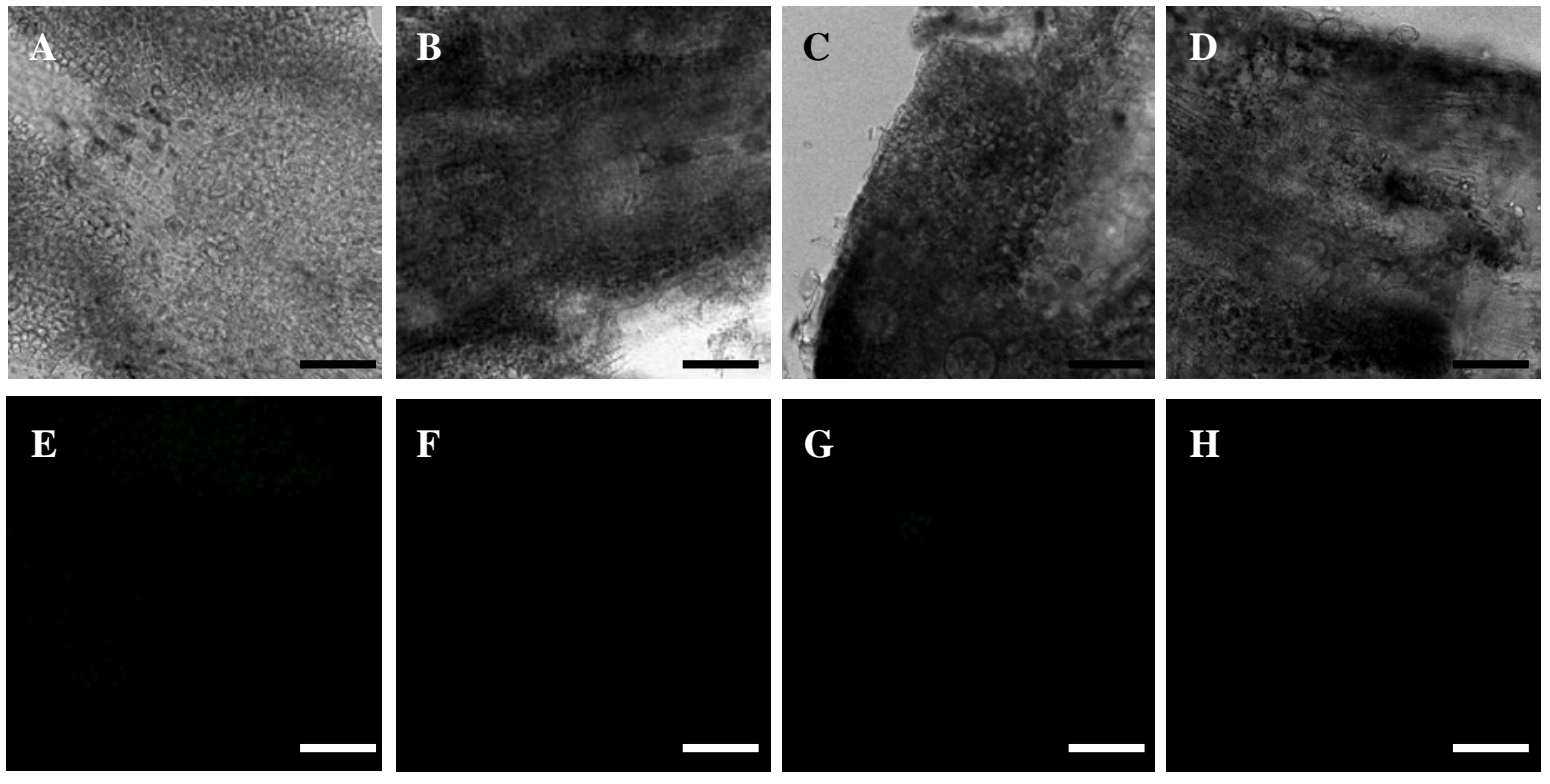

Figura 9.1. Imágenes con luz visible (A y B etapa “N”, C y D etapa “P”) o proyecciones de varias secciones ópticas recogidas por microscopía confocal que muestra la fluorescencia debido a DCF-DA en la etapa “N” con secuestrador (E) y sin secuestrador (F); en la etapa "P” con secuestrador $(\mathrm{G})$ y sin secuestrador $(\mathrm{H})$. Barra $=75 \mu \mathrm{m}$. 

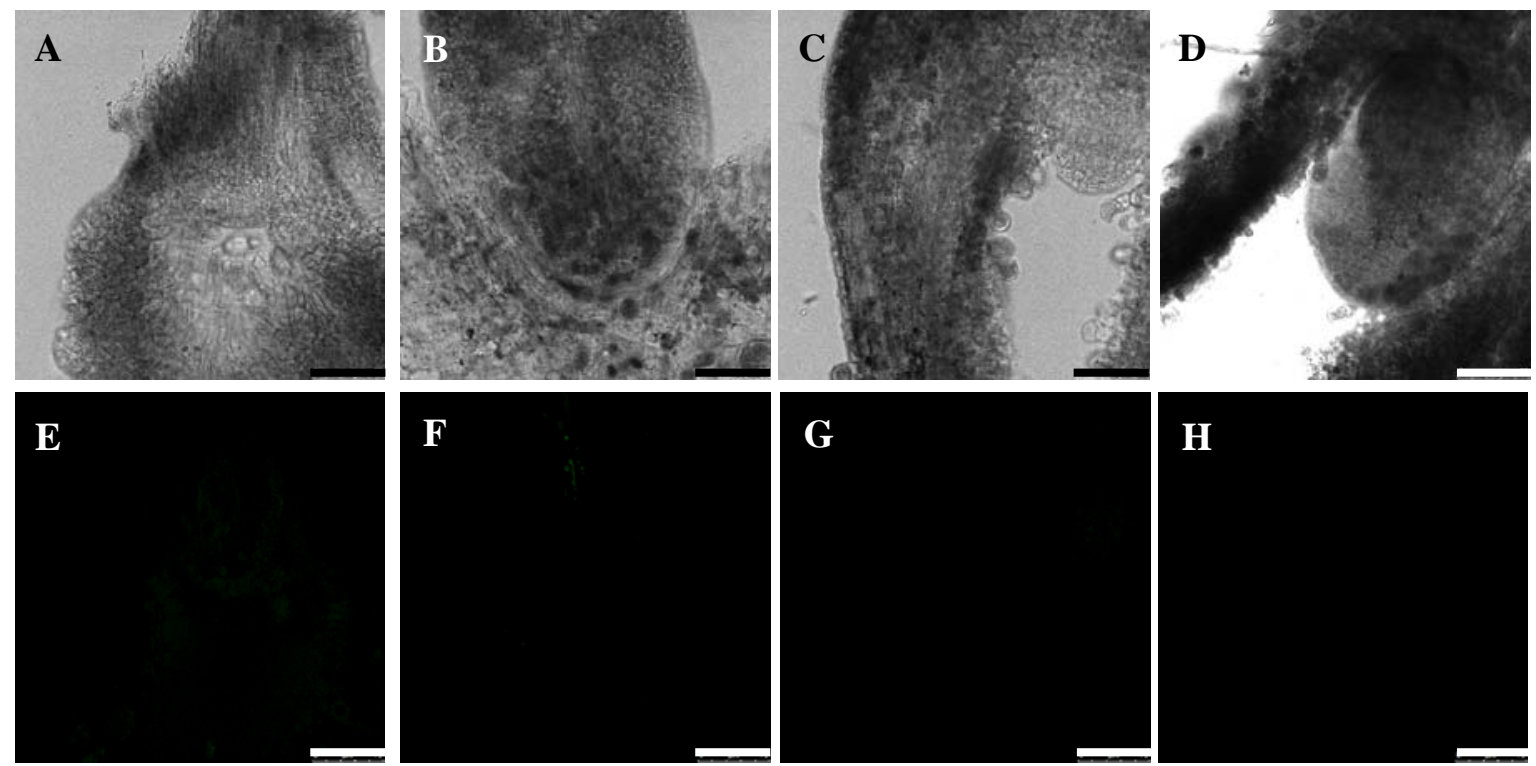

Figura 9.2. Imágenes con luz visible (A y B etapa "S”, C y D etapa”Cr”) o proyecciones de varias secciones ópticas recogidas por microscopía confocal que muestra la fluorescencia debido a DCF-DA en la etapa "S" con secuestrador (E) y sin secuestrador (F); en la etapa “Cr” con secuestrador (G) y sin secuestrador (H). Barra= $75 \mu \mathrm{m}$.
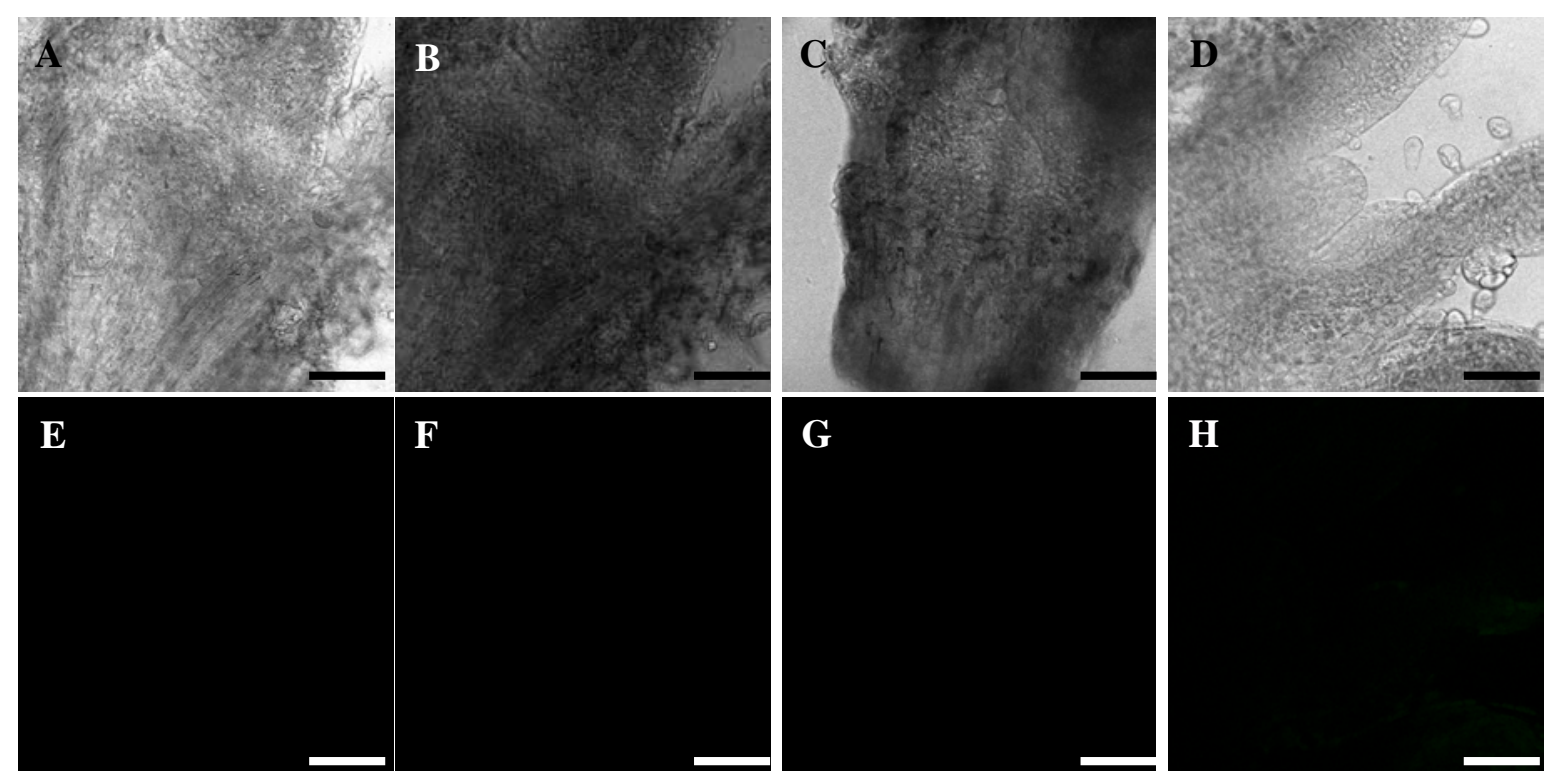

Figura 9.3. Imágenes con luz visible (A y B etapa “N”, C y D etapa "P”) o proyecciones de varias secciones ópticas recogidas por microscopía confocal que muestra la fluorescencia debido a DAF-2DA en la etapa "N" con secuestrador (E) y sin secuestrador (F); en la etapa "P” con secuestrador $(G)$ y sin secuestrador $(H)$. Barra= $75 \mu \mathrm{m}$. 

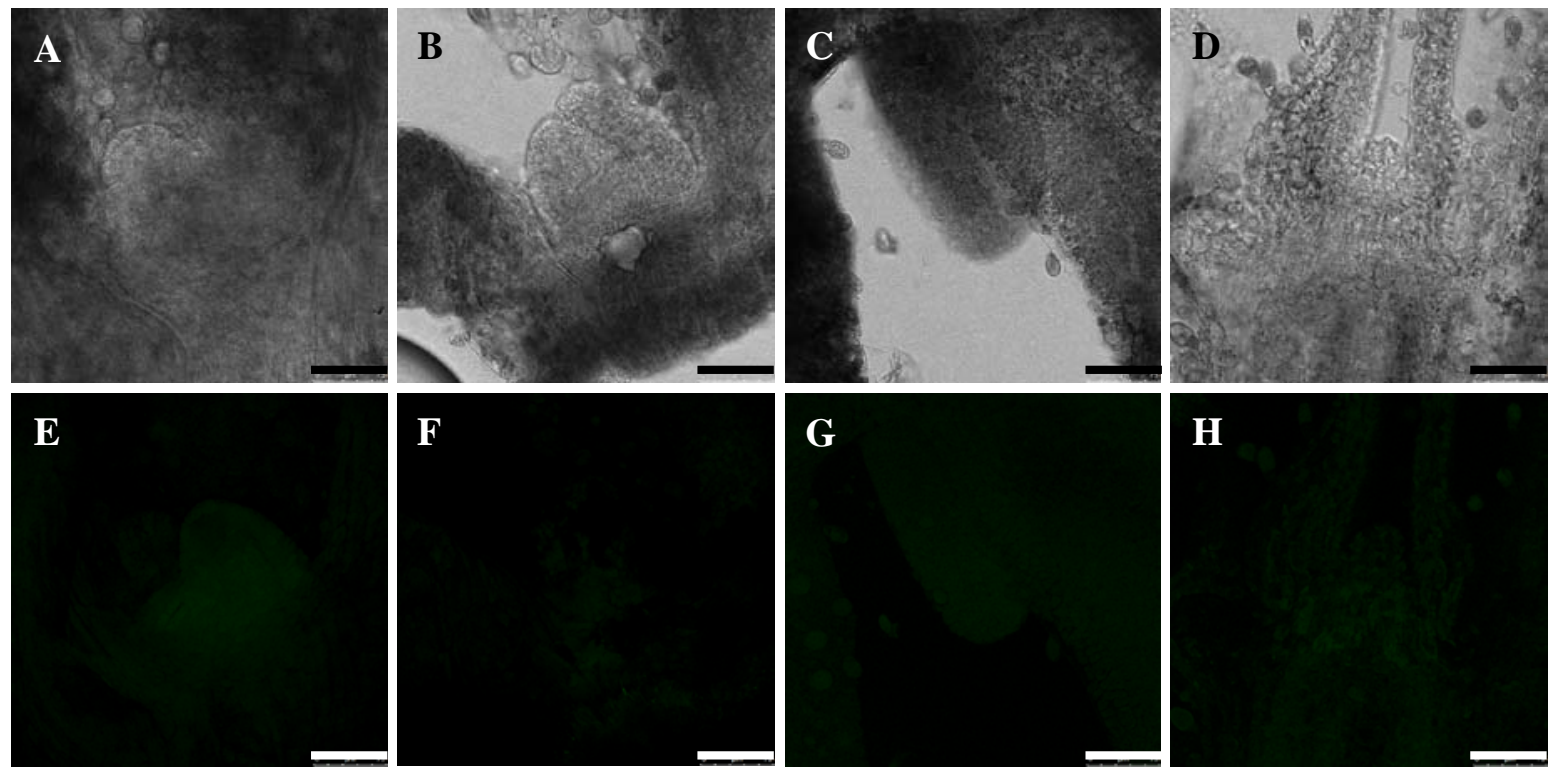

Figura 9.4. Imágenes con luz visible (A y B etapa "S”, C y D etapa “Cr”) o proyecciones de varias secciones ópticas recogidas por microscopía confocal que muestra la fluorescencia debido a DAF-2DA en la etapa "S" con secuestrador (E) y sin secuestrador (F); en la etapa “Cr” con secuestrador (G) y sin secuestrador $(\mathrm{H})$. Barra $=75 \mu \mathrm{m}$.
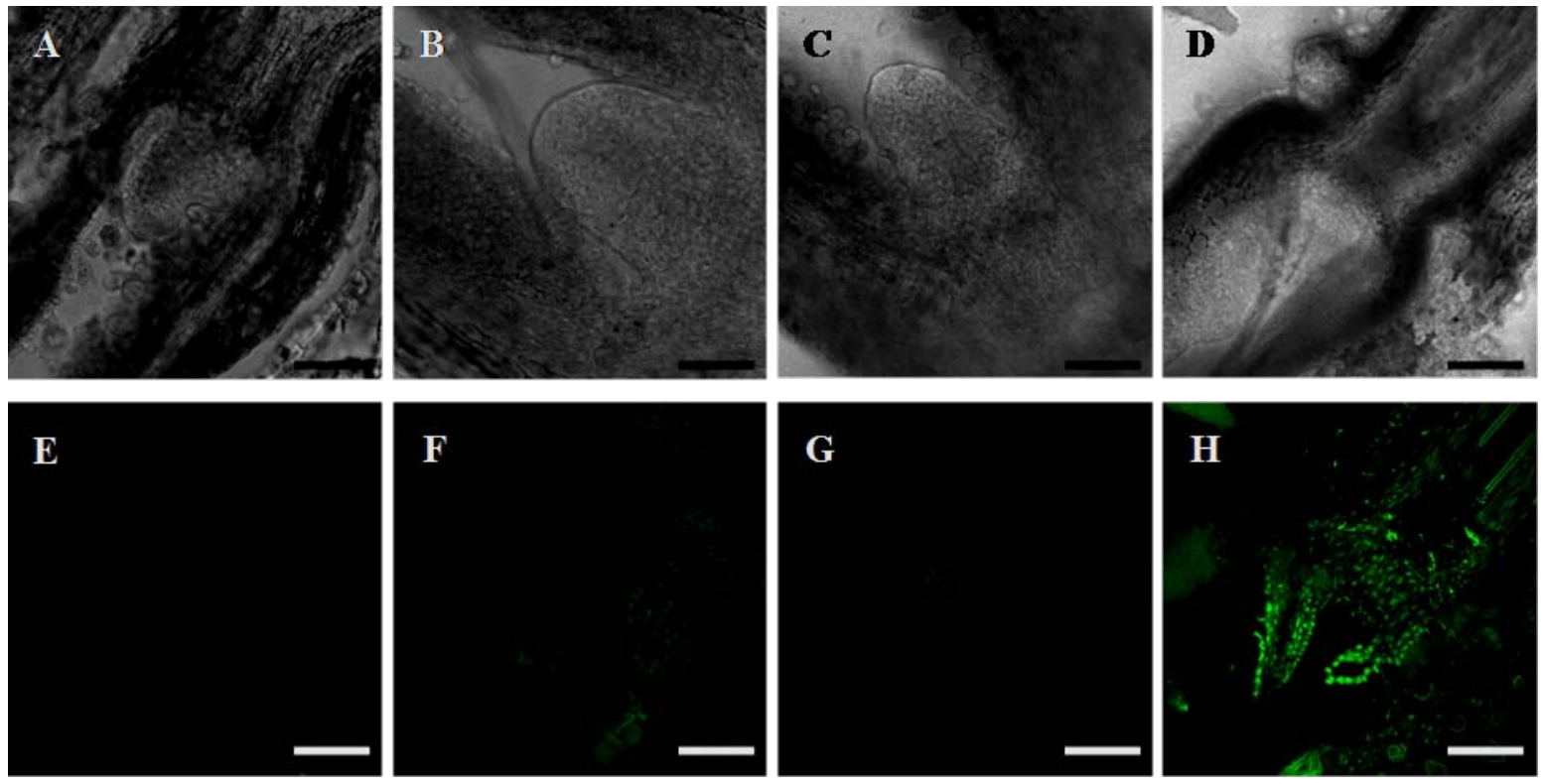

Figura 9.5. Imágenes con luz visible (A y B etapa “N”, C y D etapa “P”) o proyecciones de varias secciones ópticas recogidas por microscopía confocal que muestra la fluorescencia debido a DHE en la etapa “N” con secuestrador (E) y sin secuestrador (F); en la etapa "P” con secuestrador $(\mathrm{G})$ y sin secuestrador $(\mathrm{H})$. Barra $=75 \mu \mathrm{m}$. 

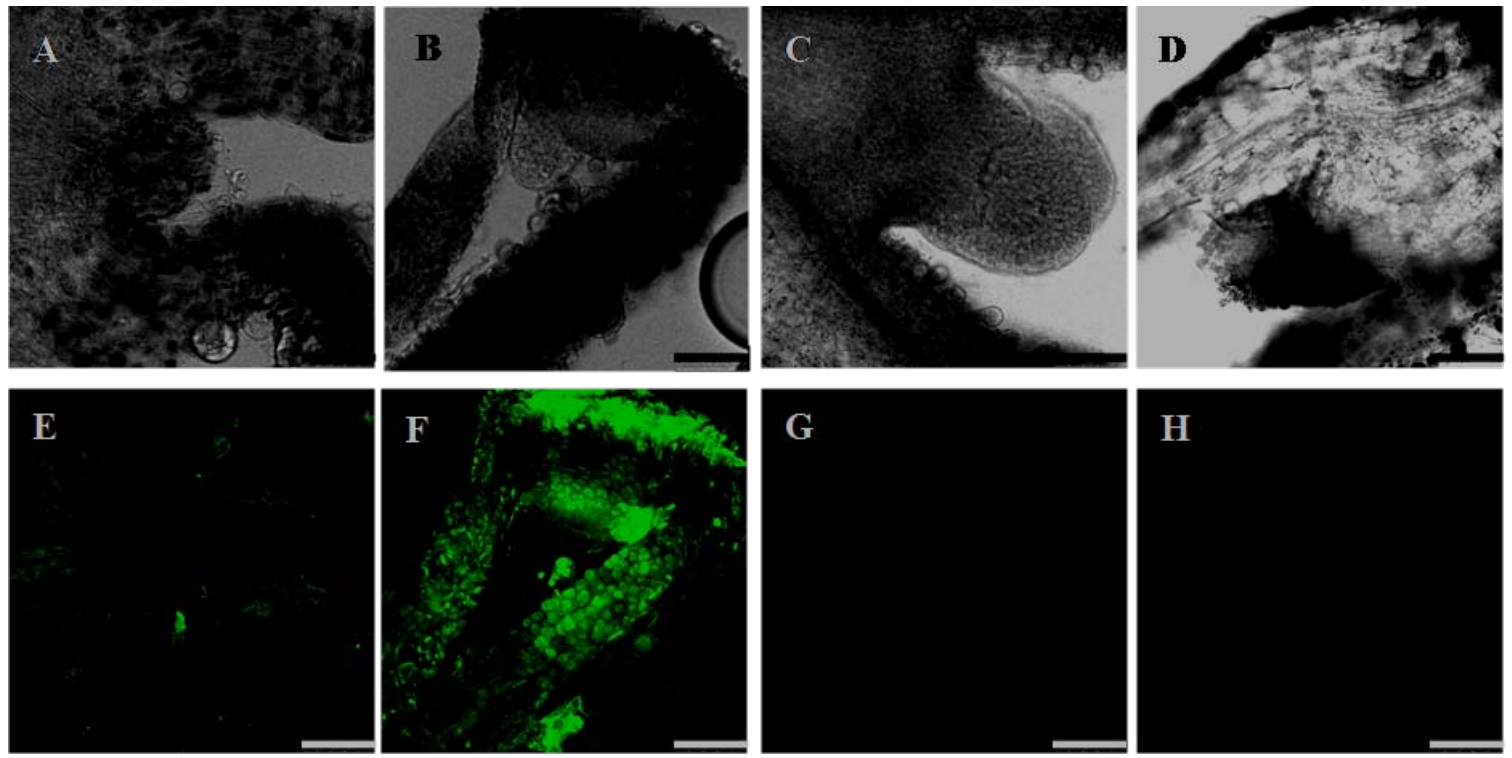

Figura 9.6. Imágenes con luz visible (A y B etapa "S”, C y D etapa “Cr”) o proyecciones de varias secciones ópticas recogidas por microscopía confocal que muestra la fluorescencia debido a DHE en la etapa "S" con secuestrador (E) y sin secuestrador (F); en la etapa "Cr" con secuestrador $(\mathrm{G})$ y sin secuestrador $(\mathrm{H})$. Barra $=75 \mu \mathrm{m}$.
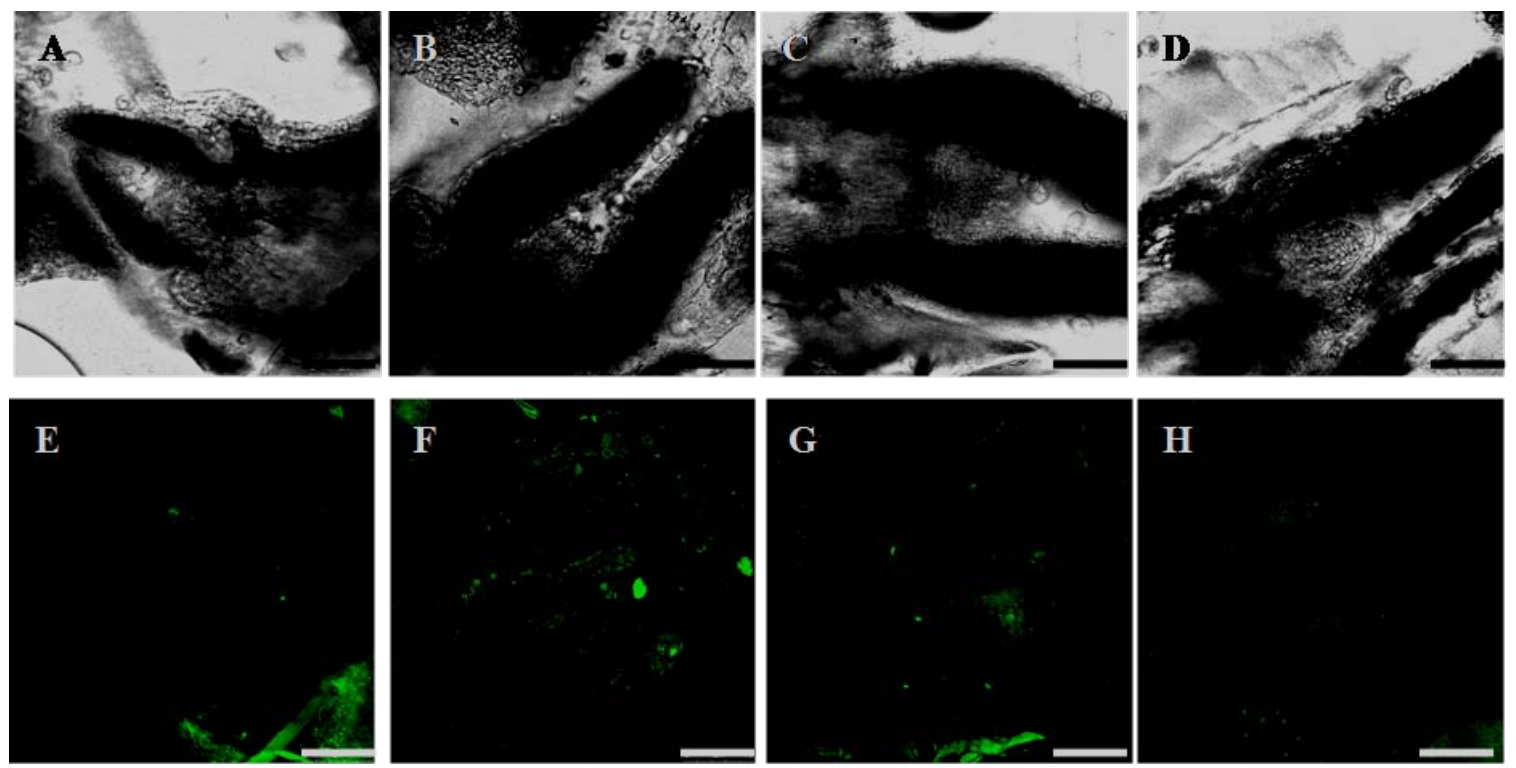

H

Figura 9.7. Imágenes con luz visible (A y B etapa "P”, C y D etapa "Pa” ) o proyecciones de varias secciones ópticas recogidas por microscopía confocal que muestra la fluorescencia debido a DHE en la etapa "P" con secuestrador (E) y sin secuestrador (F); en la etapa "Pa" con secuestrador $(\mathrm{G})$ y sin secuestrador $(\mathrm{H})$. Barra $=75 \mu \mathrm{m}$. 

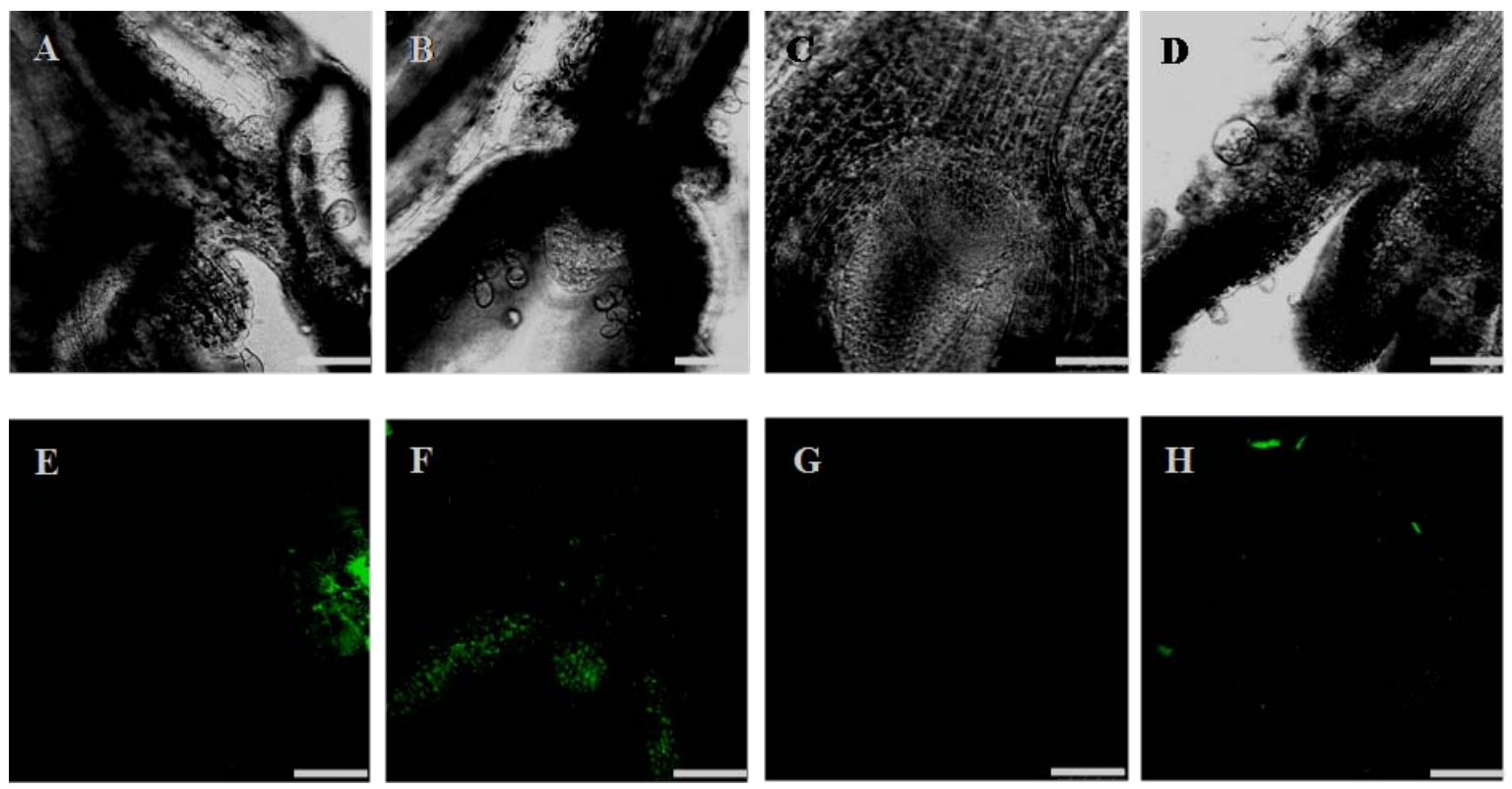

Figura 9.8. Imágenes con luz visible (A y B etapa "S”, C y D etapa "Sa”) o proyecciones de varias secciones ópticas recogidas por microscopía confocal que muestra la fluorescencia debido a DHE en la etapa "S" con secuestrador (E) y sin secuestrador (F); en la etapa "Sa" con secuestrador $(\mathrm{G})$ y sin secuestrador $(\mathrm{H})$. Barra $=75 \mu \mathrm{m}$. 